\title{
ЦИФРОВОЙ ДЕБЮТ ОБРАЗОВАТЕЛЬНЫХ ОТНОШЕНИЙ
}


УДК 378.14

ББК 74.04

Ц75

Монография подготовлена в ходе проведения исследования,

поддержанного грантом Российского фонда фундаментальных

исследований по теме «Управление развитием образовательных

отношений субъектов в начальной школе в условиях цифровизации»

(проект № 19-29-14060)

Рецензенты:

Е. И. Казакова, директор Института педагогики Санкт-Петербургского государственного университета, профессор кафедры педагогики, доктор педагогических наук, член-корреспондент Российской академии образования (Санкт-Петербург);

А. Л. Семенов, академик РАН и РАО, зав. кафедрой МГУ, директор Института кибернетики и образовательной информатики им. А. И. Берга ФИЦ ИУ РАН, зам. председателя Научно-методического совета цифровой платформы СберКласс (Москва)

Авторы: А. Н. Бакушина (гл. 6); Н. А. Заиченко, научный руководитель коллектива (гл. 2, 5); Л. И. Заиченко (гл. 4); И. Н. Кондратьева (гл. 6, 8, 9); О. Е. Лебедев (гл. 10); И. А. Писаренко (гл. 7); О. Г. Прикот (гл. 1); Д. Д. Рубашкин (гл. 3, 8, 9)

Цифровой дебют образовательных отношений : монография / под общ. ред. О. Е. Лебедева, Н. А. Заиченко. — СПб. : ИПЦ СЗИУ РАНХиГС, 2021. — 210 с. ; ил.

\section{ISBN 978-5-89781-714-6}

Акценты текстов монографии соответствуют логике исследования: от нащупывания теоретико-методологических оснований, объясняющих трансформацию образовательных отношений в период цифровизации школьного образования и сборки результатов контекстных международных исследований до интерпретации первичных результатов эксперимента по цифровым учебным практикам в начальной школе между всеми участниками процесса в цепочке «ученики - учителя - родители - управленцы». Авторы исходят из предпосылки о том, что цифровизация образования способствует трансформации базовых позиций субъектов образовательных отношений друг относительно друга. Формируются условия, определяющие необратимые изменения в системе образования.

Исследовательские подходы и промежуточные результаты эксперимента по цифровым учебным практикам в начальной школе, представленные в монографии, могут заинтересовать как исследователей феномена цифровизации школьного образования и управления этим процессом, так и практиков - учителей и управленцев. Ожидаемым для авторов монографии результатом может быть расширенная метадискуссия специалистов из разных областей наук о явлении «цифровизация образования», которое формирует для школы и всех участников образовательных отношений новую реальность.

УДК 378.14

ББК 74.04

DOI 10.22394/978-5-89781-714-6-1-202

ISBN 978-5-89781-714-6 


\section{ОГЛАВЛЕНИЕ}

Рецензент как первый читатель ................... 5

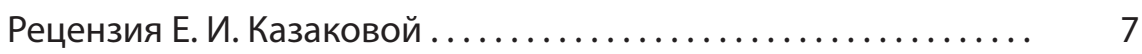

Рецензия А. Л. Семенова........................... 9

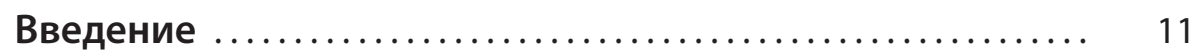

Для кого написана эта книга $\ldots \ldots \ldots \ldots \ldots \ldots \ldots \ldots \ldots \ldots . \ldots \ldots$

Раздел І. РАЗМЫШЛЕНИЯ..$\ldots \ldots \ldots \ldots \ldots \ldots \ldots \ldots \ldots \ldots \ldots \ldots \ldots$

Глава 1 Методологическая идентификация управления отношениями в VUCA-образовании:

визионерские заметки

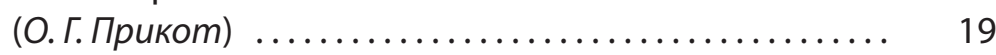

Раздел ІІ. ТЕОРИЯ. ............................... 37

Глава 2 Цифровизация образования как смена образовательных ритуалов (Н. А. Зачченко) ............................ 39

Глава 3 Цифровая трансформация школы и изменения в управлении учебным процессом (Д. Д. Рубашкин) ....................... 56

Глава 4 Цифра и агентивность учителя в международных исследованиях

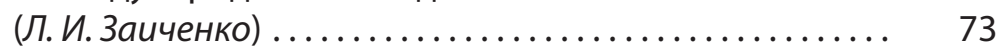

Раздел III. ЭМПИРИКА...................................... 87

Глава 5 Цифровая риторика о «цифре» в образовании (Н. А. Зачченко $\ldots \ldots \ldots \ldots \ldots \ldots \ldots \ldots \ldots \ldots \ldots \ldots \ldots \ldots \ldots \ldots$

Глава 6 Цифровое неравенство школ как предмет исследования (А. Н. Бакушина, И. Н. Кондратьева) .......... 105

Глава 7 Цифровые дети и нецифровые родители (И. А. Писаренко)............................ 125 
Глава 8 Индивидуальный тренинг в цифровой среде

(И. Н. Кондратьева, Д. Д. Рубашкин) ............ 143

Глава 9 Пилотный эксперимент

(И. Н. Кондратьева, Д. Д. Рубашкин).............. 158

Раздел V. В ЧЕМ ВОПРОС? ........................ 183

Глава 10 Образовательные отношения и ценности: зачем нам «цифра»?

(О. Е. Лебедев).................................... 185

Вместо заключения.............................. 205

Вопросы для обсуждения: зачем нам «цифра»?.............. 207

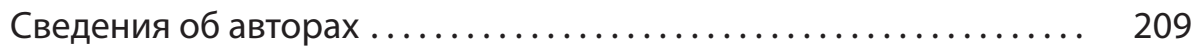




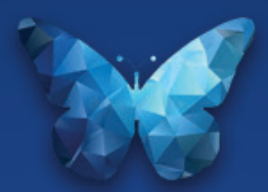

РЕЦЕН3ЕНТ КАК ПЕРВЫЙ ЧИТАТЕЛЬ 



\section{Е. И. Казакова}

директор Института педагогики

Санкт-Петербургского государственного университета, профессор кафедры педагогики, доктор педагогических наук, член-корреспондент Российской академии образования

Монография «Цифровой дебют образовательных отношений», подготовленная в ходе проведения исследования, поддержанного грантом РФФИ по теме «Управление развитием образовательных отношений субъектов в начальной школе в условиях цифровизации», безусловно дает исследовательский ответ о сущности управления развитием образовательных отношений, в том числе в начальной школе. Нет ничего удивительного в том, что, характеризуя начальную школу как «начало всех начал», авторы идут от общего к частному, а именно выстраивают общее понимание сущности процессов цифровизации образования, рассматривают проблему образовательных отношений в эпоху цифровизации, анализируют феномен восприимчивости школы к инновациям, выявляют специфику отношений к цифровизации и к образованию у разных субъектов образовательного процесса, в том числе у участников образовательного процесса в начальной школе (вот уж где острота противостояния «цифровых от рождения детей и нецифровых родителей» проявляет себя во всей полноте), изучают возможности обучения в условиях активного использования цифровых носителей.

Книга ориентирована преимущественно на коллег-исследователей; думаю, она заинтересует и систему высшего педагогического и высшего менеджериального образования, будет востребована в среде магистрантов образования и управления. Авторы справедливо отмечают, что читать ее можно с конца, с середины, читать отдельные главы; ее язык - это своеобразная эклектика, в которой сочетаются и научная логика, последовательность, обоснованность изложения, и некоторая лихость метафоричности, энергия, почти детективное развитие сюжета. Каждый автор выбирает свой язык изложения, но очевидная пестрота стиля не портит восприятия по двум причинам: мы давно перестали воспринимать «клиповое мышление» и «клиповое изложение» как явления безусловно негативные; к тому же, при всех различиях изложения, все это научные статьи, коим присущи четкая постановка задачи, аргументированность изложения, интерпретация данных, тщательный подбор источников. Эту книгу можно прочитать быстро, создав общее представление о дискурсе, а можно вчитываться в детали, вместе с авторами прослеживая и переживая рождение понимания сути новых явлений и отношений. Думаю, любой читатель не останется безучастным, и не только потому, что реальность VUCA-мира, новых образовательных экосистем, новых отношений в мире «человек - машина - искусственный интеллект - человек - общество» - это сложная реальность, в которую погружен каждый из нас, но и потому, что мир меняется стремительно, и если не участвовать в эксперименте осознанно, то следует смириться с ролью потребителя или жертвы (как повезет).

Монография посвящена культуре отношений, возникающих в системе образования и порождаемых образованием; отношений, которые больше, чем что-либо другое, определяют смыслы и значения происходящего с нами. Управление отношениями может трактоваться и как процесс воспитания, и как процесс формирования культуры познания, и как управление процес- 
сами, способствующими раскрытию личностного потенциала всех субъектов образовательных отношений в начальной школе.

Проведенное исследование позволило авторам последовательно изложить целый ряд утверждений, на мой взгляд, чрезвычайно значимых для теории и практики современного образования:

- что без персонализации образования цифровизация как минимум бесполезна, но скорее вредна и приведет к разрушению человеческого в человеке и обществе;

- что в основе системы образовательных отношений эпохи «дебютной цифровизации» лежит феномен «полисубъекта», вне которого образовательная деятельность обесценивается;

- что цифровизация создает инструменты - часто эффективные, иногда не очень, но именно инструменты, дополняющие или заменяющие привычные нам средства организации образовательных отношений...

К этим утверждениям можно добавить и блестящий тезис о повышении эффективности обратной связи в системе управления отношениями, данные международных исследований о готовности учителя к изменениям, разумное отождествление «персонализации» и «личностно-развивающего образования», исследование остроты и содержательности полемики о «цифре», гимн «большим данным» как возможному фактору управления качеством.

Безусловно рекомендуя книгу читателю, хочу посетовать на недостаточность анализа отношений «ученик - ученик» в составе «обучающейся организации» начальной школы эпохи цифровизации; конечно, авторы вольны в своей методологии действовать избирательно, но убеждена, что результативный «цифровой дебют» не может состояться без этого акцента на культуре коллективной (командной, групповой и т. д.) ответственности за качество образования в классном и школьном сообществе - особенно когда речь идет о начальной школе.

Авторы выбрали очень хорошее название. Мы все разыгрываем сейчас дебютную партию. Не секрет, что задача любого дебюта - создать условия для последующего роста и развития. Предлагаемая монография - отличный ход исследователей, которым мы теперь можем воспользоваться, выстраивая собственные отношения с миром, который «отрастил себе новую цифровую оболочку». 


\section{А. Л. Семенов}

академик РАН и РАО, зав. кафедрой МГУ, директор Института кибернетики и образовательной информатики им. А. И. Берга ФИЦ ИУ РАН, зам. председателя Научно-методического совета цифровой платформы СберКласс

Авторы коллективной монографии ставят своей целью описание и предвидение «новой реальности», «новой системы отношений» Школы. Более того, они сами участвуют в формировании этой системы отношений.

Создавая Программу РФФИ фундаментальных исследований цифровой трансформации общего образования, мы рассчитывали именно на это. Мы также имели в виду, что «видимая Цифра» - это лишь часть глобальных изменений, во многих Цифра впрямую не участвует. Но, как гениально указал Выготский, использование информационных орудий изменяет и нецифровую сущность человека там, где эти орудия не используются: появление письма сказалось и на мышлении и т. д.

Сосредоточенность именно на системе отношений обуславливает специфику, своеобразие работы и ее ценность - нельзя объять необъятное. Авторы сознательно стараются не вдаваться глубоко в возможности радикального изменения целей, содержания образования и учебной работы учащихся, которые получают возможность использовать цифровые средства, повсеместно доступные вне школы. Разумеется, эти изменения могут быть более заметными и существенными, чем изменения в отношениях, в краткосрочной для участников образовательного процесса перспективе. Например, если разрешить ученикам использовать редактор текста в курсе русского языка (и других предметов), то оказывается возможным обратиться к решению существенной задачи формирования устной и письменной коммуникативной компетентности; освоение курса математики существенно деформируется сегодня наличием интернет-решебников (ГДЗ) и автоматических решателей уравнений (UMS, Photomath). Еще раз подчеркнем, что изменения такого сорта, как и, например, кибербуллинг, - не предмет монографии.

Реально сегодня цифровизация не является существенным фактором в работе массовой школы как целостного организма. Есть лишь отдельные элементы цифровизации в современном образовании: тотальная цифровизация одного ключевого элемента - ГИА в отношениях ученика и Государства, цифровизация в отношениях «родитель - учитель» в электронном дневнике. Сейчас, в период COVID-19 мы столкнулись с массовой цифровизацией взаимодействия «учитель - ученик» в дистанционном процессе. Органично, «естественно-исторически» цифровизация в школе не возникла. Экраны и отчасти их расширения - интерактивные доски помогают учителю и в меньшей степени - ученику, став непосредственной заменой и расширением плакатов, карт и учительского «плана урока». Поэтому авторам монографии приходится по отдельным фрагментам реконструировать картину Цифрового будущего образования.

Центральным же предметом монографии является «персонализация». Кое-где она даже становится «персонификацией» сингулярности цивилизации. И действительно, весьма вероятно, что индивидуальное проектирование образования, в том числе выбора образовательных целей и путей, является сегодня наиболее действенным инструментом мотивации учащегося, а значит, и других участников образовательного процесса. И одновремен- 
но давно ожидаемая и провозглашаемая цель персонализации становится реальностью благодаря цифровизации. Контуры этой реальности видятся в масштабном движении, уже не эксперименте, результативного образования Сбера. Это движение, представленное обоими рецензентами монографии, может в ближайшем будущем использовать многие модели и выводы монографии, подтвердить (или опровергнуть, что тоже увлекательно) ее прогнозы.

Пытаясь вписать рассматриваемый круг вопросов - трансформацию образовательных отношений в традиционные рамки, можно вспомнить о «школоведении», «организации образовательного процесса», «укладе школы». Авторы смело отказываются от традиционной терминологии, оставаясь в основном в пределах законодательно закрепленного понятия «образовательных отношений». При этом, например, для выделения специфики современного момента используется понятие «агентивности» вместо самостоятельности и активности, «ритуал» вместо «уклад», «дисциплина» и т. д. Авторы используют и вводят большой терминологический аппарат, часто транскрибируя англоязычные термины (когда-то было принято в таких случаях просто использовать немецкий или иной термин, не транскрибируя). Будем надеяться, что это не сильно затруднит использование книги и не очень снизит ее популярность среди читателей.

Одной из важных черт монографии является то, что авторы последовательно рассматривают наряду с «реальными» явлениями и отношениями их отражение в сознании тех или иных участников образовательного процесса или социальных групп. Это совершенно закономерно и является достоинством книги. Мифологизация понятия «цифра» в образовании сегодня становится все более существенным фактором по сравнению с пока ограниченным (до пандемии) реальным эффектом от применения цифровых технологий в образовательном процессе. Мало кто пытается обсуждать вопрос обеспечения всеобуча одномерно с санитарным благополучием населения - чтобы каждый ребенок в период пандемии дома, в школе, или где-то еще имел доступ к экрану и нормального качества Интернету. При этом СМИ с радостью тиражируют информацию о родителях, протестующих против дегуманизации = цифровизации образовательного процесса. Похожую картину мы видим последние годы в политизации исходно нейтрального, кодифицированного понятия «услуга» в применении к образованию.

На другом конце спектра от визионерства и социологии массового сознания в монографии представлены результаты масштабной многолетней работы, можно сказать, формирующего эксперимента по «тренингу» учебных действий в начальной школе. У рецензента не поднимается рука снять кавычки в термине «тренинг», используемом авторами. Противопоставление тренинга, drill-and-practice уже стало аксиомой современной педагогики развития. Однако авторы смело ломают формирующиеся стереотипы, показывают, как «программированное обучение» в современной интерпретации может стать действительно гуманным инструментом развития ребенка для достижения такой цели, как понимание текста, например.

Можно выразить надежду, что рецензируемая монография (конечно, в своем цифровом виде в первую очередь) станет «наэкранной книгой» современного учителя, управленца, каждого заинтересованного в судьбе российской школы. 


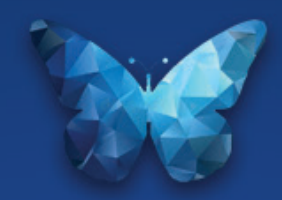

ВВЕДЕНИЕ 



\section{ДЛЯ КОГО НАПИСАНА ЭТА КНИГА}

Цифровизация образования в условиях школы представляет собой необратимый процесс с неопределенными последствиями. Таким же необратимым процессом является демократизация образования, которая выражается в поэтапном повышении доступности все более высоких уровней образования. Все более массовым становится высшее образование. С повышением доступности более высоких уровней образования связаны проблемы достижения его качества, соответствующего современным социальным запросам. Эти проблемы решаются с большим трудом, но процесс демократизации остановить невозможно.

Изменения в системе образования, обусловленные процессом цифровизации, носят как позитивный, так и негативный характер: оцениваются эти изменения в профессиональном сообществе и в обществе по-разному. Но остановить процесс цифровизации нельзя, как невозможно было прекратить процесс книгопечатания, который стал основным фактором создания массовой школы.

Если следствия процесса цифровизации пока не вполне ясны, то на этапе «цифрового дебюта» было бы важно повлиять на развитие этого процесса, чтобы предотвратить возможные риски и использовать возможности цифровизации образования для повышения его качества. Для управления процессом цифровизации образования необходимо выяснить, чем надо и чем можно управлять в этом процессе. В любом случае речь идет об управлении поведением участников образовательного процесса - педагогов, родителей обучающихся, самих учащихся, школьных администраторов, у которых складывается свое отношение к происходящим и возможным изменениям, а в связи с этим и свои образовательные стратегии.

Эта книга написана по материалам исследования «Управление развитием образовательных отношений субъектов в начальной школе в условиях цифровизачии», поддержанного грантом РФФИ (проект № 19-29-14060).

Под субъектами понимаются педагоги, родители, ученики и руководители школ, под образовательными отношениями - отношения между участниками образовательного процесса. Что понимается под управлением развитием образовательных отношений и в чем может заключаться развитие этих отношений - вот об этом и говорится в данной книге. Исследование не завершено, оно продолжается, и результатом уже проведенной исследовательской работы являются скорее вопросы, чем ответы на них.

Цифровизация образования - явление сложное, противоречивое. Ответы на возникающие вопросы можно получить, если в анализ этого явления будет вовлечен широкий круг заинтересованных лиц.

С точки зрения авторов, эта книга может представлять интерес:

- для тех, кто исследует трансформационные процессы в системе образования; 
- для тех, кто рассматривает себя как благополучателя или как жертву процесса цифровизации;

- для тех, кому предстоит принимать управленческие решения, обусловленные процессом цифровизации.

Если читателя интересуют исследовательские вопросы, то имеет смысл обратить внимание на теоретические основы данного исследовательского проекта. Цифровизация образования представляет собой сложное, многогранное явление, которое может быть рассмотрено с различных точек зрения. В разделах данной книги можно найти ссылки на работы Акоффа, Краевского, Асмолова, Выготского, Днепрова, Винера, Ядова, Уварова, Парсонса, Геннепа, Штомпки и многих других исследователей (включая публикации самих авторов).

Такое многообразие имен свидетельствует о том, что исследователям процесса цифровизации в системе образования неизбежно приходится решать проблему методологического самоопределения при выборе собственного предмета исследования. В данном случае объект исследования у всех авторов один - это процесс цифровизации школьного образования, но предмет исследования у каждого автора свой.

Многообразие подходов к исследованию процесса цифровизации выразилось в понятийном аппарате, который используют авторы. Понятно, что в состав этого аппарата вошли термины, которые традиционно используются в междисциплинарных исследованиях (система, ценности, эволюция и др.). Но новизна объекта исследования привела к попыткам заимствовать терминологию из других областей знания, не имеющих прямого отношения к сфере образования (учебные и образовательные ритуалы, агентивность, лиминальность, цифровое детство, нецифровое родительство и др.).

Исследование проблемы управления развитием школьных образовательных отношений в ситуации цифровизации образования привело к выводам о важности изучения ряда проблем развития образования, которые выходят за рамки цифровизации. К их числу относятся вопросы о факторах, определяющих необратимые изменения в системе образования, логику развития образовательных систем и организаций, а также вопросы о роли субъективного фактора в развитии трансформационных процессов в сфере образования.

Отдельный раздел книги посвящен конкретному экспериментальному исследованию влияния цифровизации учебного процесса в начальной школе на изменение характера отношений участников данного процесса.

Цифровизация учебного процесса в начальной школе стала объектом исследования по двум причинам: во-первых, на этом этапе начинается процесс формирования у учащихся отношения к себе как субъекту образовательной деятельности, способному анализировать и оценивать свои учебные действия; во-вторых, на этапе начального обучения легче использовать инновационные учебные практики, поскольку у детей не сформировались стандартные ритуалы учебного поведения и родители учащихся начальной школы обычно проявляют готовность к сотрудничеству с учителями. Опыт этого исследования может быть интересен не только тем, кто занимается проблематикой начальной школы, но и всем, кого привлекают вопросы информационного обеспечения управления учебным процессом.

Обычно в ходе педагогического эксперимента проверяется связь между использованием каких-либо педагогических средств и достижением пред- 
полагаемого результата. В данном случае представлена другая ситуация выявляется возможность получения большого объема существенной информачии через иирровые следы о ходе и результатах учебного прочесса, но остается не вполне ясным, какие педагогические и управленческие решения могут быть приняты на основе анализа и оценки этой информации.

Если читатель является непосредственным участником прочесса чифровизации, то для него могут представлять интерес те разделы книги, в которых рассматриваются межсубъектные отношения участников этого процесса и их отношение к самой цифровизации.

Трансформационные процессы в системе образования происходят независимо от того, нравится или нет это людям, которые вовлекаются в данные процессы. Но при этом возникает необходимость определить свою роль в том или ином процессе. Условно можно выделить роли «объекта» и «субъекта» процесса. В первом случае человек пытается каким-то образом адаптироваться к происходящим изменениям, во втором случае - повлиять на эти изменения в соответствии с собственными целями.

Для того, кто принимает позицию «субъекта» (в терминах европейских исследователей - проявляет агентивность), могут быть интересны предлагаемые в книге версии ответов на вопросы о сущности субъектной позиции в образовательном процессе, факторах, влияющих на данную позицию, о возможностях процесса цифровизации и его рисках. Предлагаемые версии ответов не стоит рассматривать как «единственно верные». Но они дают возможность определить круг собственных размышлений о происходящих изменениях и предмет возможных обсуждений в профессиональном сообществе.

Если читателя интересуют проблемы управления образовательным процессом, то в этом случае стоит обратить внимание на саму постановку вопроса об управлении отношениями в системе образования. Одна из основных задач управления заключается в обеспечении необходимого качества образования.

Уже достаточно давно проблема качества образования решалась за счет отсева учащихся, которые в силу разных причин не могли освоить образовательную программу. С переходом к всеобщему обязательному образованию, продолжительность которого постепенно увеличивалась, этот путь стал невозможен. Была сделана ставка на достаточно жесткую регламентацию образовательного процесса (единые учебники, единые программы, единые требования к уроку и т. п.). Обязательные требования к образовательному процессу стали сочетаться с требованиями к обязательным результатам к показателю успеваемости. Следствие данного подхода - имитация деятельности и снижение ответственности участников образовательного процесса за качество своей деятельности. Ориентация на «управление по результатам» (по примеру управленческих инноваций в сфере экономики), предполагающее достаточную свободу участников образовательного процесса в выборе средств реализации поставленных целей, не получила должной поддержки на уровне образовательной политики, но привела к обсуждению самой сущности образовательных результатов и роли субъективных факторов в их достижении.

Получила развитие концепция управления отношениями, которая исходит из того, что формирование отношения к образованию как личностной ценности и опыта межсубъектных отношений является и значимым 
результатом образования, и определяющим фактором достижения всех образовательных результатов. Субъектная позиция участников образовательных отношений предполагает их способность к определению целей своей образовательной деятельности, выбору средств их реализации и принятию на себя ответственности за ее результаты. Данная концепция в известной мере представлена в разных разделах книги.

Особенности структуры данной книги таковы, что ее можно читать, начиная с любого раздела. Последовательность разделов имеет определенную логику: сначала обсуждается вопрос о методологических основах исследования процесса цифровизации образования, затем предлагаются теоретические обоснования разных аспектов образовательных отношений в условиях цифровизации, рассматриваются различные варианты предмета исследования и описывается опыт конкретного исследования. Завершается книга главой, посвященной проблемам развития образовательных отношений с ценностных позиций, в том числе в условиях цифровизации образования, и вопросами, которые могут стать предметом дискуссий, исследований, формулировки гипотез и принятия управленческих решений в профессиональном сообществе. Можно начать чтение с вопросов, можно - с описания эксперимента и затем обратиться к обсуждению теоретических основ других возможных исследований, ориентированных на решение конкретных задач цифровизации образовательного процесса. А можно ограничиться ознакомлением с отдельными главами, представляющими интерес для читателя.

Главы написаны в разных стилях. За этим стоит не только признание права авторов на индивидуальность, не только понимание многообразия читательских позиций, но и убежденность в потенциале «иного взгляда».

Благодарим наших активных участников эксперимента по цифровизации образовательных отношений в начальной школе (см. раздел IV «Эксперимент») и многотысячной когорты респондентов, которые помогли нам поставить новые исследовательские вопросы и дать основания для формулирования гипотез, проверка которых может состояться на следующем этапе проекта по гранту РФФИ «Управление развитием образовательных отношений субъектов в начальной школе в условиях цифровизачии».

Суважением, авторы Август 2021 г. 


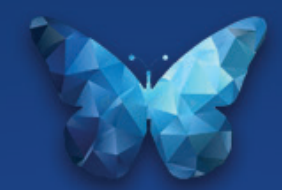

Раздел I

РАЗМЫШЛЕНИЯ 



\section{ГЛАВА 1}

\section{Методологическая идентификация управления отношениями в VUCA-образовании: визионерские заметки}

«Методологические пазлы» об управлении образовательными отношениями сначала возникли как акоффское «Проблемное месиво» [Акофф 1985]. Именно из него я попытался «вылепить» свою управленческую VUCA-конструкцию1. Этот великий визионер подсказал мне путь через свои пять «катапультирующих» идей [Акофф 2004]. Он вдохнул в эту конструкцию душу. А окончательно «оживил тело» другой великий визионер - академик Краевский [Краевский 2001, 2006]. Свободная диалектика пересекающихся визионерских пространств породила энергию творения образовательных экосистем, воскресила методологию неопосредованных феноменологических описаний [Акофф 2004, 2007].

И еще об одном. В этом тексте я почти ничего не буду говорить про пандемию COVID-19. И, естественно, даже не попытаюсь высказаться о том, как ее приход повлиял на образовательные смыслы и образовательные отношения. Потому что если это один из «черных лебедей», то через обозримое время последствия его «прилета» забудутся и большинство людей будут удивляться своим страхам и радоваться возвращению привычного. А если это свидетельство проявления становления «новой реальности», порождающей актуальную действительность, то тогда придется исследовать предпосылки возникновения новых институтов, основываться на данных, которые еще надо получить, обработать, интерпретировать, осмыслить результаты.

\section{Интермедия 1. «Немного экстремистская» VUCA-методология...}

Великие «правильные» теории проверяются годами. А иногда десятилетиями или даже столетиями. У мира VUCA такого бэкграунда за плечами нет. Емy, если мерить по YouTube, Facebook, базовым блогам, влогам, некоторым другим «ветеранам движения», и двадцати лет не наберется. Времени для привычной «теоретической» проверки гениальных VUCA-догадок типа «Стратегия умерла», «Организация - тропический лес» или «Школа - коралловый риф» в этом мире не было, нет и не будет... Так же как, скорее всего, не удастся выстроить систему доказательств «обратным ходом» - создать

${ }^{1}$ VUCA - акроним слов volatility (нестабильность), uncertainty (неопределенность), complexity (сложность), ambiguity (неоднозначность); термин использовался в 1980-х гг. в военных училищах США. 
на базе практики «хорошие» теории, подтвердив одну из самых популярных научных максим [Душенко].

Поясним сказанное на простом, понятном каждому примере. Если представить себе «тысячелетнюю» экспозицию образовательного мира, то легко увидеть, что со времени расцвета клинописи, с помощью которой были зафиксированы на черном базальтовом столбе Законы царя Хаммурапи (почти за четыре тысячи лет до сегодняшнего времени), то можно отметить в указанном мире всего только три (!) глобальные образовательные реформы. Первая - собственно «реформа» самого Хаммурапи (или скорее реформа на базе таблички из Киша, которой уже больше пяти с половиной тысяч лет). Ведь никто точно не может сказать, кто и где эту самую клинопись, давшую начало рукописным книгам - основе первой образовательной «реформы» и индивидуально-группового обучения, изобрел.

Так продолжалось до времени Иоганна Гутенберга, до середины XV в., когда рукописные книги в средневековых школах и университетах были заменены на печатные, что привело к первой «массовизации» образовательного процесса. Еще примерно через сто лет Ян Амос Коменский уложил все это в актуальное до совсем недавнего времени прокрустово ложе фронтального образования, именуемого «классно-урочной» системой. И все это, до уже упомянутых «Facebook \& YouTube» и нынешних «маркетплейсов», отлично себе существовало и развивалось в течение трех с половиной сотен лет.

A потом случился информационный взрыв VUCA-мира. Рамки текста не позволяют нам вволю порассуждать о природе его базовых трансформаций. В одном только наши наблюдения нас убеждают: пресловутая цифровизация «всего» - лишь небольшая часть изменений VUCA-мира, видимая часть айсберга, если можно так выразиться. Ее проявления ярко заявляют о себе в форме, понятной большинству людей, потому как приходят к нам в качестве средств удовлетворения устойчиво закрепленных на определенных уровнях сознания базовых потребностей, обеспечивающих желанные потребительские иллюзии. Так получилось, что рынок почти беспрепятственно манипулирует нашим сознанием. Ибо нет, по выражению Маркса, процитировавшего в первом томе «Капитала» английского профсоюзного деятеля Томаса Даннинга, того преступления, на которое не пошел бы капитал ради трехсот процентов прибыли. К последствиям начального этапа цифровизации часто пытаются отнести ценностно-этические трансформации, связанные с «цифрой». Если воспользоваться «старой доброй» и потому понятной читателю причинно-следственной логикой, то, как нам представляется, налицо подмена понятий, ибо в этом случае следствие занимает место причины. Результаты наших наблюдений позволяют нам констатировать, что скорее этические трансформации в сознании людей влияют на характер явления. Ведь только измененные ценности, которые не присущи машинам, позволяют людям думать о создании самообучающихся чат-ботов, а не наоборот... Вместе с тем, если следовать идее контринтуитивности, высказанной на заре VUCA-эпохи Джамшидом Гараедаги [Гараедаги], причина и следствие во время быстрых глобальных трансформаций - зачастую одно и то же...

Однако завершим мысль об основаниях VUCA-изменений. Мои чувства и опыт говорят мне, что цифровизация - лишь форма информационных трансформаций, которые, в свою очередь, например в виде особым образом организованных «больших данных» (big data, BD), являют нам действительную 
(проявленную) часть лежащих в их основе энергетических трансформаций, представляющих «реальное» (скрытое «настоящее») [Прикот 1997], в том числе так называемых «тонких энергий» (в просторечье именуемых «духом» или «душой»), о значении которых для научного познания писал в своей книге «Дао физики» лауреат Нобелевской премии Ф. Капра [Капра]. О значении подобных «энергетических игр» говорил один из основоположников современного холизма С. Гроф [Гроф], а также, обосновывая роль метафор в научном познании, В. В. Налимов [Налимов]. Однако эти ссылки на научные авторитеты прошлого мы делаем в известном доверительном интервале. Образно говоря, слишком много воды унес Ганг в Индийский океан за двадцать четыре года, как ваш покорный слуга написал свою «инонаучную» докторскую диссертацию [Прикот 1997]. Я в своей докторской для обозначения подобных явлений «скрытой реальности» применил термин «инонаука».

B мире VUCA сколько людей - столько методологий. Быстрота изменений не позволяет успеть договориться. У каждого человека может быть столько «личностей-персон» (масок), что идентифицировать их можно только сиюминутно-персонально, но подвести под процесс идентификации «хорошую» теорию не получается. Не получается даже обобщить, тем более синтезировать методологические положения, выдвигаемые персонами.

Поэтому сколько людей - столько и методологий. Методология превращается в персонифицированный феномен, перестает быть «научным», даже наукообразным явлением, становится фактором искусства, «креативной индустрии», постепенно превращаясь в наррацию - сказку. Главное self-skill нынешнего методолога - профессиональная компетентность, если хотите - моментальная идентификация окружающих его персон. В том числе своих собственных.

Поэтому чель этого текста - не научить пользоваться очередным методологическим инструментом (это невозможно в приведенных контекстах). Цель - рассказать, как исследуются образовательные персоны, объединенные никнеймом «PRIKOT». (Возможно, вослед этому рассказу у вас появится желание поискать адекватные инструменты для исследования своих собственных персон.)

\section{Интермедия 2. Про феноменологию}

А теперь немного о педагогических исследованиях. Точнее - об исследованиях в образовательной сфере, коими я и занимаюсь.

Я пытаюсь исследовать образовательные экосистемы. Точнее - ищу свидетельства проявлений становления экосистемной логики развития в образовательных системах и организациях. Ищу в обыденном. И становящемся формально институализированным. Традиционный институт, коротко говоря, это традиции, выраженные в норме. Подробнее о социальных институтах, различных трактовках понятийного ряда и явления в целом смотрите в рамках онлайн-курса Н. А. Заиченко «Институциональные основы образовательной политики» [Заиченко Н. 2021]. Кто-то скажет, что я вульгаризирую, упрощаю предельно представление об институте. Но для феноменологического описания этого достаточно, потому что это и есть реально наблюдаемое. Все остальное, «глубинное» от реального наблюдателя скрыто. Кстати говоря, я, по тем же «феноменологическим» соображениям, «вульгаризирую» и понятие 
«институциональной ловушки» [Полтерович], сведя представление о ней к «эффекту колеи» в духе А. Аузана [Аузан].

Но все это - об институте SPOD-мира ${ }^{2}$, который мы часто, по привычке пытаемся сделать институциональной моделью мира VUCA, воспроизводя тем самым «проклятое прошлое».

A в VUCA-образовании работает другая модель институализации. Я позволил себе назвать ее «неполноценной», или «запаздывающей». Методологическая институциональная мысль не успевает за VUCA-трансформациями, «запаздывает». Как правило, инерционное, основанное на устойчивых ценностях - традиции. Попытки искусственно «подстегнуть» изменение традиций порой приводят к необоснованно оперативной формализации норм, когда не естественный путь становления традиций приводит к трансформации нормы в тот или иной закон, а создается иллюзия возможности обратного. Однако при этом включается фактор имитации, подрывающий доверие к традиционному институту и не приводящий к возникновению нового.

Мы имеем в последние годы массу подобных VUCA-свидетельств: традиции, основанные на терминальных ценностях, еще не сформированы, а норма, регламентирующая реализацию управленческих решений, уже принята. В классике норма закона должна утверждать сформировавшиеся традиции. B мире VUCA зачастую происходит наоборот - закон уже есть, а традиций еще нет. В этом случае закон «насилует» действительность. И иногда все-таки добивается формирования неорганических, привнесенных извне системы и потому «ублюдочных» традиций. Пример - ЕГЭ. Тут вроде бы даже комментировать нечего. Кстати, его побочный эффект был хорош — «переворачивание» пирамиды доступности более-менее качественного высшего образования с пресловутых «80/20» в пользу выпускников петербургских и московских школ в престижных «столичных» университетах до введения ЕГЭ на «20/80» в пользу лучших выпускников других регионов в тех же университетах в настоящее время.

Но базовый эффект - измерение качества общего образования угнездил в образовательном мейнстриме те самые «ублюдочные традиции», которые выразились в превращении «натаскивания на ЕГЭ» в сущность базового образовательного процесса, превратили балл ЕГЭ в главный образовательный результат российской школы, в «кистень» тотального контроля за сферой общего и отчасти высшего образования.

Другой пример - компетентностный ФГОС СОО, превращенный в имитационную иллюзию из манифеста продуктивного образования в очередной малопривлекательный жупел разлагающейся классно-урочной «фантасмагории», мумифицирующий ее, превращающий в откровенную толкиеновскую нежить [Толкин].

Еще одним примером измерения SPOD-шкалами мира VUCA-образования может служить попытка реализовать в образовательной сфере идею профессиональной стандартизации.

Я позволил себе исследовать этот процесс, и основной вывод, к которому я пришел: стандарты в мире VUCA-образования, как и стратегии, «умирают» в том смысле, что превращаются в «непривычное», то есть теряют коренной, казалось бы, признак для устоявшихся образований - долгосрочную устой-

2 SPOD - акроним слов steady (устойчивый), predictable (предсказуемый), ordinary (простой), definite (определенный); SPOD-мир - устойчивый мир. 
чивость. Действительно, разработка, принятие и утверждение профессионального стандарта в сфере образования, как показывает практика работы с пятью действующими в настоящее время в отечественном образовании профстандартами, занимают не менее двух лет. Позволю себе высказать предположение, что за это время резерв квалификации современного учителя, школьного психолога, педагога дополнительного образования значительно изменяется. Например, в настоящее время действуют два таких мощных, хотя и не рядоположенных фактора, как «пандемизация» и «цифровизация» образования.

И если основа современной образовательной стратегии - максима «Из сегодня - в сегодня», выведенная мною на основе выкладок Рассела Акоффа [Акофф 2004, 2007], то «стратегический» характер профстандарта должен определяться таким же образом. Проще говоря, содержание профессиональных стандартов в мире VUCA-образования должно меняться непрерывно в рамках своеобразного пространственно-временного континуума. И чтобы это происходило, профстандарт должен быть сверхзначимой переменной в профессиональном развитии педагога. То есть он должен быть социальным институтом, устоявшейся и закрепленной в соответствующей норме традицией, согласно которой сертификат соответствия профессиональному стандарту при приеме на работу для работодателя важнее, чем диплом о высшем образовании. Но становление подобной традиции происходит на протяжении десятилетий. Образно говоря, для VUCA-изменений в сфере профессиональной стандартизации в западной интерпретации десятилетиями создавался SPOD-фундамент. Это положение закрепило социальную значимость профстандарта в общественном сознании. Оно и стало основой для перманентной трансформации его в мире VUCA. B российской образовательной традиции подобное положение не закреплено, профстандарт не является социально и профессионально значимой переменной. Работа по его постоянной трансформации сложна, результат ее неоднозначен и слабо контролируем. Поэтому легче сделать профессиональные стандарты в образовании явлениями «параллельной реальности», которые можно при случае просто не замечать... Есть закон — нет традиции. Профессиональный стандарт педагога как бы действует...

Показателен пример «истории с персонализацией», характерной для отечественного образования эпохи VUCA, одним из принципиальных контекстов которой является так называемая «цифровизация образования».

В контексте актуальной трансформации образовательного процесса в современной школе главное условие его цифровизации - это, с нашей точки зрения, постепенный переход от традиционной дидактической системы через дифференциачию и индивидуализацию обучения к его персонализированной модели.

По нашему мнению, внешние атрибуты цифровизации: технические, технологические, сервисные, программные решения - не являются определяющими ее образовательные смыслы, хотя, безусловно, оказывают значительное влияние на формирование новых образовательных ценностей, увеличивают темпы персонализации образования. Другими словами, можно сказать, что персонализация - первична, и цифровизация - средство персонализации образования, однако средство, оказывающее серьезное влияние на содержание целей его развития, их корректировку. Примером может служить процесс реализации в образовательных организациях различного 
уровня аутентичной образовательной модели Дж. Дьюи. Модель, презентованная педагогическому сообществу в первой четверти XX в., получает массовое распространение в школе только в контексте использования возможностей современных цифровых ресурсов [Концепция...].

Таким образом, цифровизация способствует запуску процесса массовизации проявления персональных ценностей в образовании (продуктивная метафора — «Разное хорошее образование для каждого»), тогда как индустриальная эпоха способствовала иллюзорной массовизации «Одинакового хорошего образования для всех». Очевидно, что реализуема в действительности только первая метафора. Вторая, как и основанные на ней цели, абсолютно нереалистична в силу различий между людьми. Поэтому методологически правильно будет констатировать, что именно персонализированные образовательные системы эпохи цифровизации только и актуальны в объективной действительности.

Актуальные представления о цифровой трансформации образовательного процесса в современной школе в контексте становления моделей ПРО (персонализированного результативного обучения), SAMR (Substitution, Augmentation, Modification, Redefinition), четыре уровня внедрения цифровых технологий в образовательный процесс школы, представлены специалистами НИУ ВШЭ в фундаментальном докладе «Трудности и перспективы цифровой трансформации образования» [Трудности...].

Актуальные контексты формирования и развития необходимых «цифровых» компетентностей участников образовательных отношений представлены в других работах Института образования НИУ ВШЭ [Анализ...; Переход...; Проблемы...; Учащиеся...; Цифровая...; Цыплят...].

Глубоко раскрыты проблемы трансформации образовательных отношений в начальной школе в условиях цифровизации в работах моих уважаемых коллег по гранту [Заиченко Л. и др.; Заиченко Н. 2020; Заиченко Н., Набокова; Лебедев; Писаренко, Заиченко Л.].

Основа понятийного ряда при исследовании вышеуказанных вопросов, с нашей точки зрения, - «персона» - театральная маска в любой деятельности. Смена масок - прерогатива субъекта, свидетельство его активной роли в любой деятельности. Надевая маску, субъект кодирует желаемый результат своей активности, принимает, по сути, управленческое решение инструмент достижения желаемого результата. На основании исследования маски окружение распознает именно тот образ субъекта, который наиболее приемлем для него в актуальной ситуации. Таким образом, маска («персона») - средство влияния субъекта на внешнее изменение, элемент его динамической эволюции как саморегулируемой системы. Персона - триггер карнавала. Карнавал - базовая деятельность мира VUCA, фактор, определяющий суть трансформации образовательных отношений. «Смена ролей, разрыв дистанций» — я говорю об этом, вослед М. М. Бахтину...

Таким образом, если убрать промежуточное звено в виде карнавала, получается, что именно персонализация определяет суть трансформации современных образовательных отношений.

Логика динамической эволюции саморегулируемой системы - это логика экосистемного развития. Действительно, кораллы Большого Барьерного рифа реагируют на изменение направления океанских течений, температуры воды, потоков питательных микроорганизмов и тому подобного отнюдь не механически, как неживая неразумная система, не просто подстраиваясь, 
а реализуя собственные интенции, изменяясь наиболее благоприятным для себя образом. И, тем самым, определенным (иногда весьма значительным) образом влияя на сами внешние изменения. Если перенести некоторые положения из сказанного на процесс развития образовательных систем, мы должны будем констатировать, что экосистемная логика развития приобретает новые краски в результате синтеза экосистемной методологии с методологией «мультиразумности» бытия сложных живых систем.

Мультиразумная система, по Дж. Гараедаги [Гараедаги], это система (организация), элементы которой способны (правомочны) делать выбор. Критическим параметром является цель. Совместить интересы целеустремленных элементов друг с другом и с целым - вот главная задача организации. В отличие от машин, части которых достаточно объединить в единое целое всего один раз, для организаций процесс интеграции - вечная проблема и непрекращающаяся борьба.

Образовательная экосистема, в интерпретации результатов собственных гайд-исследований [Прикот 2021] и обобщений в контексте мирового образовательного мейнстрима, осуществленных экспертами «Лукша - Тим» [Образование для...; Образовательные экосистемы...], может быть презентована так:

- это сеть образовательных пространств («сеть сетей»), которые свободно пересекаются, перетекают друг в друга;

- «межсистемные» («тектологические») границы между ними условны, изменчивы, неопределенны;

- сеть саморегулируется, саморазвивается («динамически эволюционирует»);

- сеть свободно обменивается с окружением энергией и информацией, пребывает в состоянии перманентной трансформации;

- сеть сохраняет информационно-энергетическую устойчивость благодаря высокому уровню доверия в системе.

Образовательная экосистема - место встречи индивидуальных и институциональных провайдеров образовательных услуг и персонализированных потребителей, конструирующих свой образовательный путь в контексте непрерывного образования.

Образовательные экосистемы в контексте становления VUCA-образования характеризуются феноменом «карнавализации», то есть разрывом привычных социальных дистанций и трансформацией традиционных образовательных ролей: «все учат всех, все управляют всеми».

Таким образом, персонализированная образовательная экосистема это результат системной идентификации образования в VUCA-мире.

Цифровая трансформация образования - один из факторов развития образовательных экосистем.

Если это фактор-средство, то в этом случае - это «поставка» BD для принятия управленческих решений персонализированного характера, которые принимает субъект и за которые он несет ответственность в свободном для участия других субъектов четырехмерном континууме пространства, времени, энергии и информации.

Если цифровизация - фактор-цель, то превалирует внешняя логика «каналов и траекторий», когда BD в контексте традиционного уже Machine Learning являются «индивидуализированным маршрутизатором», то есть «принимают на себя» ответственность за образовательные судьбы людей 
в логике оруэлловского «Большого Брата» [Оруэлл] или платоновского «государства философов» [Поппер]. Эта логика не допускает наличия у кого бы то ни было масок-«персон», поскольку их наличие служит препятствием для универсальной, стандартизированной внешней идентификации.

И начинает действовать «оксюморон», разрушающий саму логику цифровизации как средства персонализации образования живых субъектов. Цифровизачия как средство персонализачии («персонификации») образования возможна только при отсутствии персон.

Весьма полезно для осмысления процесса исследования вопросов персонализации («персонификации») образования замечание А. Г. Асмолова, Е. Д. Шехтер и А. М. Черноризова: «Характерной особенностью персонификации является взаимодействие через систему символов и смыслов (персонамаска), поскольку интерпретируется внутренний мир „другого“, ни при каких условиях не доступный непосредственному наблюдению» [Асмолов и др., с. 203]. Нам представляется, что уважаемые авторы льют воду на мельницу феноменологического подхода к исследованию феномена персонификации. Внутренний мир персонифицированного субъекта действительно недоступен для изучения с помощью непосредственного наблюдения, однако мы получаем возможность наблюдать смену масок, которая говорит нам о смене внутренних интенций субъекта, дает информацию о принятых персоной решениях о его ценностных трансформациях, осуществляемых в контексте изменений внешней среды. Поэтому мы полагаем, что процедуры феноменологического исследования, позволяющие осуществлять в том числе включенное наблюдение за процессом смены масок (в нашем случае - гайд-исследование, осуществленное на основе интерпретации текстов гайд-интервью), результаты применения которых будут описаны мною в других работах, надо надеяться, позволят выявить актуальные свидетельства проявлений персонализированной логики в развитии исследуемых образовательных экосистем.

Мультиразумные образовательные организации-экосистемы существуют в контексте конкретизирующей VUCA-процессы в образовании преадаптивной логики развития образовательных систем и организаций.

Универсальный смысл понятия преадаптации раскрыт в упомянутой выше книге [Асмолов и др.]. Ее авторы определяют понятие как «феномен опережения непредсказуемых изменений» [Там же, с. 80]. Они указывают, что преадаптация есть «освобождение от диктатуры прошлого опыта» [Там же, с. 94] и связана «со скачкообразной качественной реорганизацией системы» [Там же]. А. Г. Асмолов отмечает, что именно феномен преадаптации может обеспечить «баланс стабильности и изменчивости» [Там же, с. 14].

Исследование сути преадаптивной логики многое объясняет в трансформационных процессах в сфере управления организациями и системами в мире VUCA-образования. Этим мы займемся после рассмотрения сущности еще одного примера. Представляется, что это действительный пример гармоничного сосуществования традиции и нормы закона в контексте становления действительного феномена VUCA-образования. Речь ниже пойдет о кванториумах и кванторианском движении.

Исследуя Кванториум, мы будем доказывать следующую гипотезу:Кванториум - становящаяся персонифицированная образовательная экосистема, образовательный феномен VUCA-образования. Изучая феномен Кванториума, мы введем искусственную рамку, за границами которой остается поиск аналогов. Нами будет предпринята попытка включения в исследовательский 
процесс методологии феноменологического описания, предполагающей непосредственное наблюдение (в том числе включенное) за изучаемым явлением, исключающей сравнение состояний феномена с аналоговыми моделями, требующей сопоставлять различные аспекты его бытия только между собой, подчеркивая уникальность и неповторимость явления. С нашей точки зрения, только таким образом мы сможем продемонстрировать принципиально новую природу Кванториума как феномена VUCA-образования. В этой связи я позволил себе высказать еще ряд гипотетических положений, которые отнес к «институциональным»: для феноменов VUCA-образования характерно весьма гармоничное сосуществование традиции и нормы закона. Следование нормы за традицией более не абсолютизировано. Традиция и закон служат триггерами развития друг друга, «запаздывание» и/или «опережение» какой-либо части институциональной конструкции более не является критичным. Преадаптивная природа VUCA-образования как раз и предполагает своеобразную временную и смысловую «смену лидерства» традиции и закона. Этим, по нашему мнению, и обеспечиваются пространственная, информационная, энергетическая и временная «гибкости» в контексте «бифуркационных» трансформаций, переживаемых современными образовательными экосистемами на пути их становления.

Итак, есть образовательный феномен - Кванториум, есть нормативное решение в рамках национального проекта «Образование» (федеральный проект «Успех каждого ребенка»), Указ Президента РФ № 474 от 21.07.2020, погружающий развитие отечественного образования в контексты национальной цели «Возможности для самореализации и развития талантов». Таким образом, есть закон и, с другой стороны, быстро набирающие силу традиции кванторианского движения³

В ходе нашего исследования мы пытаемся доказать, что это становящиеся традиции персонализированной логики построения образовательного процесса, логики стартапов, продуктивного образования через продукто-ориентированную проектную деятельность, эдьютейнмента как базовой философии современного образования (не «процедуры» или «технологии» - довеска к скуке обыденного основного образования), расшколивания, стирания границ между основным и дополнительным образованием (постепенным, но последовательным превращением второго в первое), трансформации «маршрутно-канальной» методологии организации «индивидуализированного образования» в методологию свободно пересекающихся персональных образовательных пространств, информационно-энергетического континуума.

С применением методологии феноменологического описания, наряду с исследованием экосистемной логики развития Кванториума, осуществлен поиск свидетельств проявления становления образовательных экосистем в рамках исследования регионального мультикейса — образования Ленинградской области ${ }^{4}$.

\footnotetext{
${ }^{3}$ См. сайт «Роскванториума», сайты региональных кванториумов, гайд-исследование, вплетенное в ткань упомянутого выше моего авторского онлайн-курса «Стратегическое управление в образовании: методология и кейсы проектных решений», кейс «Кванториум Санкт-Петербург». Указанный курс стартовал в июне 2021 г. на открытой платформе российских университетов ореnedu.

${ }^{4}$ Итоги этого исследования будут представлены в готовящейся в настоящее время статье.
} 
Напомним кратко особенности феноменологического описания как метода научного исследования:

- непосредственное наблюдение за явлением;

- выводы на основе непосредственного созерцания;

- результаты наблюдения - предмет интерпретаций персонального сознания;

- основа интерпретаций - продукты «интенционального сознания» («Система существует только в голове системолога»);

- феноменологическое описание пригодно для исследования живых систем, поскольку позволяет преодолеть последствия заключения в прокрустово ложе теорий.

Метод феноменологического описания основан на положениях современной феноменологии, отцом-основателем которой мы числим Эдмунда Гуссерля [Гуссерль].

Карнавал правит в мире VUCA-образования. Привычные социальные роли трансформируются самым причудливым образом. Так называемые ученые практически утратили способность предвидеть развитие практики, все более отстают от образовательной действительности. В следующей интермедии в рамках настоящей главы я попытаюсь рассмотреть этот процесс с позиций системной идентификации настоящего. Традиционный исследовательский метод не позволяет угнаться за скачкообразными трансформациями действительности. Значительное время, привычно затрачиваемое на изучение образовательных явлений, приводит к тому, что, когда явление изучено и даны соответствующие рекомендации практике, смысла в этих рекомендациях уже почти нет, так как часто и само изученное явление уже перестало существовать как часть образовательной действительности. Например, на курсах повышения квалификации для управленческих команд образовательных организаций повсеместно продолжает изучаться процесс разработки и реализации долгосрочных («стратегических)) программ развития, основанный на результатах многолетних исследований специалистов в области управления образованием, тогда как многие практики понимают, что гораздо результативнее изучать, например, не процесс контроля за ходом реализации целей и задач долгосрочной программы, а вероятные механизмы трансформации этих целей или отказа от цели как императива.

Осмелюсь предложитьследующееуниверсальное определениестратегии, которое, по моему мнению, подойдет и для VUCA-образования: это персонально обоснованный путьдостижения главной целиразвитиясистемыв актуальный период времени, в условиях неопределенности и непредсказуемых скачкообразных изменений внешней и внутренней среды [Прикот 2020, с. 10].

Специфика управления образовательной организацией определяется тем, что это организация со «слабыми связями». Это, с моей точки зрения, и есть основа системы внутренних предпосылок внедрения проектного управления, соответствующего изменения внутриорганизационной философии. Речь идет о слабых связях между базовыми процессами (учением, преподаванием, научной, инновационной, социальной активностями и т. п.). В таких организациях, находящихся в состоянии перманентного кризиса, при этом очень высока степень устойчивости к системным изменениям. Это связано с тем, что слабые связи предполагают разную степень воздействия, оказываемого на различные части системы в контексте внешнего изменения, и, как следствие, неравномерность прохождения управленческих сигналов 
внутри организации. То есть мы можем констатировать наличие парадокса, определяющего сущность процесса развития образовательных систем: чем слабее связи между базовыми прочессами в организации, тем выше степень ее устойчивости в период кризиса. Можно констатировать, что проектное управление в образовании позволяет ослабить негативные последствия попыток управления базовыми процессами с помощью периферийных. Речь идет о широко распространенном в настоящее время так называемом процессе менеджеризации жизнедеятельности образовательных организаций, следствием которого является так называемая менеджериальная иллюзия. В ходе указанного процесса происходит сужение субъектной базы управления. Все определяющие процесс развития решения принимаются менеджерами, которые, не являясь хозяевами базовых процессов, пытаются изменять их содержание исключительно с помощью внешних воздействий (формальных регламентов). Такое положение совершенно определенным образом сказывается на характере образовательных отношений, на сути методологии управления ими. Суть еще одного аспекта, на который следует обратить внимание при определении принципов управления образовательными отношениями в любой современной образовательной организации, выражена в продуктивной метафоре "Доверие и солидарность». По отношению к управлению социальными системами метафора применена в визионерской статье В. А. Мау, который, в частности, пишет: «Солидарность и доверие ключевые ценностные установки наступающей эпохи, определяющие новую парадигму общественной жизни человечества» [Мау, с. 11]. Очевидно, что для становления идеологии проектного управления метафора «доверия и солидарности» приобретает принципиальный характер. Более того, выскажу гипотезу о том, что именно процесс проектного управления, способствующий включению хозяев базовых процессов (учителей, родителей, учеников) в принятие управленческих решений, значимых для их профессионального и образовательного пути, создаст благоприятные возможности для персонификации деятельности образовательной организации.

\section{Интермедия 3. Ученые}

Поскольку ваш покорный слуга имеет честь входить в состав Совета по методологии научных исследований РАО, мне случилось быть участником дискуссии о влиянии ученых на процесс и результат принятия управленческих решений, определяющих судьбы отечественного образования. Одним из влиятельных членов Совета была высказана мысль о том, что предотвратить некачественные, часто неадекватные современному состоянию российских образовательных систем и организаций управленческие решения и последующие действия органов управления может выработка учеными РАO и университетских научных сообществ «методологически выверенных технологий влияния на деятельность органов управления образованием на федеральном и региональном уровнях». Я позволил себе вступить в дискуссию, по итогам которой родилась предлагаемая интермедия. Это еще одна ипостась образовательных VUCA-отношений...

Четыре тезиса:

1) представление о том, что такое эти самые «методологически выверенные технологии влияния...», существует только в головах ученых, 
а управленцы, на решения которых предполагается влиять, об этом даже не догадываются - «Система существует только в голове системолога»! [Лао-цзы; Медоуз; О'Коннор, Макдермот] — иначе не бывает...;

2) системология, с постулатами которой вряд ли получится поспорить, требует от нас, в раскрытие предыдущего тезиса, системной идентификации образования в контексте реализации именно управленческих процессов, результат которой для меня очевиден: и ученые, и управленцы - части одной системы, где базовая «технология влияния» менеджериальная иллюзия, смысл которой в том, что система управляется хозяевами периферийного процесса (то есть управленцами), а не одного из базовых процессов (учеными). Организационно образовательная система, как система со слабыми связями, по М. Грановеттеру [Granovetter], должна быть вроде бы в этом случае неустойчива, но эта проблема «стабилизации» решена просто: ученые отказались от своих «хозяйских» прав ИНСТИТУЦИОНАЛЬНО (традиционно и «законодательно»), подчинившись воздействиям бюрократического ядра системы, в обмен на обеспечение ресурсами, поддерживающими жизнедеятельность, на уровне согласно рангам, определенным и культивируемым тем же ядром. В общественно-институциональном договоре ученых и управленцев в настоящее время трансформирующее воздействие первых на вторых не предусмотрено. Полагаю, что уровень ресурсного обеспечения жизнедеятельности, например ведущих ученых РАН, РАО, других «государственных» академий, а также профессоров ряда основных российских университетов, сохраняющих статус-кво в сообществе, даже в настоящее время таков, что он не предполагает реального сопротивления менеджериальной иллюзии и попыток идентификации собственного бизнес-процесса в качестве базового. А без этого какое-либо воздействие на периферийные, «возомнившие» себя базовыми, триггеры системы невозможно [Голдсмит, Рейтер];

3) исходя из сказанного выше, можно с большой долей достоверности предположить, что никаких «методологически выверенных технологий, влияющих на решения управленцев» от образования просто по определению не может существовать. А констатация их наличия (или проявлений), без трансформации институциональных условий указанного выше «общественного договора», - не более чем имитация, которая надежно запечатывает двери нашей научной «башни из слоновой кости» той самой бергмановской «седьмой печатью» [Седьмая печать]... Во всяком случае, если числить методологию частью системного научного «месива» в акоффском смысле...;

4) выше мы уже отмечали, что традиционная общественная наука слишком медлительна, и привычным образом организованный, базирующийся на проверенных годами теориях, использующий верифицированные методы и процедуры исследовательский процесс часто рассматривает уже завершившие свой жизненный путь социальные явления и события. Поэтому часто самые маститые ученые становятся «отставшими навсегда». И управленцы начинают их использовать для обоснования задним числом уже принятого решения. А подобная деятельность не предполагает принятия ответственности, присвоения 
себе права «решать». Такие ученые, пребывающие в гордыне своей «параллельной реальности», все более теснимы «сказочниками», которые, образно говоря, не боятся предсказывать скрытую реальность, лежащую в основе развития социальных (образовательных) феноменов, а не объяснять явленную действительность, которая суть опосредована реальностью и потому вторична. «Сказочники» - нарраторы в мире VUCA уверенно присваивают себе право (и ответственность) на свои «ненаучные» («инонаучные») предсказания, не тратят время, которого нет, на исследования, результат которых часто устаревает (теряет смысл) еще в процессе получения. Увы, «нормальный» ученый не может пока избавиться от двух «проклятий» SPOD-мира - анализа, предшествующего системной идентификации явления, и «дурной» экстраполяции. Это естественные спутники традиционного исследовательского процесса SPOD-науки. Разные там «деревья целей», отношения «цель - задача», «объект - предмет», прыжки «из вчера в завтра» и наоборот, минуя «сегодня», застят нам глаза на ту самую радость бытия «здесь и сейчас», которая только и имеет смысл для мира людей... И если это не научный результат сертифицированного ученого, а наррация - сказка талантливого криейтора, то так тому и быть! K несчастью ученых, в мире VUCA (образования) в актуальном «сегодня» время для научных исследований, по крайней мере традиционно экспериментального толка, почти исчерпано. В будущем его также нет, ввиду отсутствия такового. Масса времени для подобных «полночных экзерсисов» имеется в прошлом - кого-то это утешает... Ведь в прошлом действуют классическая ОТС, тектология Богданова, в прошлом - Выготский, «наше все», в прошлом - невольный, может быть, приверженец радикального мессианства ницшеанско-уайльдовско-оруэлловского толка в образовании, «левый коммунист» Иван Иллич [Иллич; Ницше; Оруэлл; Прикот 2000; Уайльд] — для многих теперь главный «образовательный» визионер. В прошлом - ваш слуга покорный со своими «пятью педагогиками» [Прикот 1995].

А еще в прошлом очень скоро может остаться профессор, который начинает учить студента, не задав сначала себе вопрос «Чему я сам могу у него научиться?». И если академик не способен учиться у восьмилетних ALPHA LUDENS (я позволил себе в рамках своего онлайн-курса добавить к наименованию «ALPHA», данному Марком Маккриндлом [McCrindle; McCrindle, Fell], позаимствованный у Йохана Хёйзинги [Хёйзинга] эпитет «LUDENS»), то многие из нас, «профессоров-академиков», застанут трагифарс «Гибель тысячелетних университетов и школ». И научных школ иже с ними.

\section{Интермедия 4. Решения ответственного визионера (VUCA-решения)}

Эта интермедия - просто короткий конспект самого себя. Стопка «методологических пазлов», если позволите. Право складывать которые мы предоставляем вдумчивому, заинтересованному читателю - хотя бы на том основании, что предложение варианта готового панно есть вмешательство в пространство его персональной методологии, ценностная неприкосновенность которого для нас свята... А стопка деталей - просто предложение по- 
играть имеющимся материалом по своим правилам. Надо же с чего-то начинать. Но если материал не понравился - примените свой собственный, я не в обиде! Все наши два десятка фрагментов образовательной управленческой VUCA-мозаики либо впрямую упомянуты в предыдущих интермедиях, либо проявляются контекстно. Если все положения, которые вы увидите ниже, попытаться хоть сколько-нибудь подробно раскрыть, то это займет непозволительно много места, которое лимитировано в рамках содержательного пространства монографии. Поэтому я позволю себе обозначить только их базовые смыслы - основы для «методологических» решений стратегического характера для VUCA-образования и привести ссылки на содержание уже упоминавшегося в настоящем тексте онлайн-курса «Стратегическое управление в образовании: методология и кейсы проектных решений» [Прикот 2021], несложная регистрация на котором по приводимой мною прямой ссылке позволит заинтересованному пользователю подробно ознакомиться с содержанием и образами, создающими базовые контексты приведенных в тексте положений.

Итак, вот обещанные «пазлы» управления образовательными отношениями VUCA-образования в формате продуктивных метафор, в духе творчества В. В. Налимова [Налимов]. Миникластеры (19 единиц) предъявляются по мере возникновения в тексте, без ранжирования по значимости; «сборка» возможна только в контексте персональных методологий:

- VUCA-институализация: Диалектика Традиции и Закона. «Неполноценные» «Опережение» и «Запаздывание»;

- VUCA-стратегирование: «Из сегодня - в сегодня», «Радость здесь и сейчас». Стратегическая пентаграмма - «Звездочка Прикота» [Прикот 2021];

- VUCA-цифровизация: «Оксюморон цифровизации» VUCA-образования. «Персонализация при отсутствии персон...»;

- Персонализация: «Маски-шоу». «Маска, я тебя знаю!» [Асмолов, Шехтер, Черноризов];

- Карнавал «Перевернутое образование»: «Все учат всех». «Между нами только маски...» [Бахтин];

- Мультиразумная организация: «Все управляют всеми». «Моя свобода заканчивается у кончика Вашего носа...»;

- Образовательная экосистема: «Тропический Лес». Образовательная система как четырехмерный континуум свободной коммуникации Пространства, Информации, Энергии, Времени. «Коралловый Риф»;

- Преадаптация: «Предвидеть непредсказуемое». «Будущее наступило!». «Изменяя изменения» [Асмолов, Шехтер, Черноризов];

- Феномен и феноменологическое описание: «Великое сидение на берегу Ганга...» [Гуссерль];

- Организация со слабыми связями: «Сила слабых связей». «Хозяева базовых процессов». «Менеджериальная иллюзия» [Прикот 2018, 2019];

- Максима Доверия и Солидарности: Вовлекающее распределенное проектное управление. «Я тебя вижу...»;

- «Проблемное месиво»: «Система есть нечто большее или нечто меньшее, чем сумма ее частей» [Акофф 1985];

- Диалектика реального и действительного: «В начале было слово. И слово было...» [Прикот 1997];

- Бесконечное число методологий: «Ловушка Координации...» [Полтерович; Прикот 1995]; 
- «Наука VUCA — инонаука»: стихотворный пазл [Прикот 1998];

- Трансформационное («вовлекающее») лидерство: «Приносить людям радость здесь и сейчас» [Образовательные экосистемы...; Шляйхер; Прикот 2021; Робертс; Робинсон];

- «Перевернутое образование»: «Дополнительное образование как основное». «,Гений места“ как школа...»;

- «Три кита» продуктивного образования: персонализация, расшколивание, эдьютейнмент «Teach Like a Pirate!». «Чему я могу научить своего учителя?» [Бёрджес];

- Гайд-исследование как процедура феноменологического описания образовательной экосистемы: «Прыгая через настоящее, мы воспроизводим прошлое...» [Прикот 2021].

\section{Вместо заключения: еще раз про карнавал}

Из-за пределов вышеописанной SPOD-системы влиять на управленческие решения в действительном VUCA-пространстве нынешнего образования может только «вовлекающий» трансформационный лидер, «изменяющий изменения», цель которого вовсе не «методологически выверенные технологии влияния», а радость, которую он принесет людям здесь и сейчас, по Кевину Робертсу [Робертс], - только это в мире VUCA-образования способствует реальному развитию главного «методологического» ресурса в системе - ДОВЕРИЯ.

Экосистемный образовательный VUCA-карнавал смешал привычные образовательные роли, разорвал традиционные социально обусловленные дистанции [Бахтин], наложил друг на друга кажущиеся несоединимыми образовательные пространства, мягко трансформирует «платформенную канализацию» в виде всяких там «маршрутов» и «траекторий» в единый информационно-энергетический континуум - место встречи живых сущностей с изменчивыми «гениями места». И потому так просто представить образовательную систему в образе «Тропического Леса» [Сендж] или «Кораллового Рифа» [Hannon]. При этом субъекты образования легко идентифицируют себя со множеством масок-персон, именно так ощущая персонализацию, иррационально творя ее... В этих инонаучных контекстах методология на самом деле у каждого своя. По-иному теперь нельзя...

А за окном сегодня - Карнавал Пандемии.

Столько разных масок! Персонализачия как она есть...

\section{Источники}

\section{Лumepamypa}

1. Акофф Р. Л. Менеджмент в XXI веке. Преобразование корпорации: пер. сангл. Томск: Изд-во Том. ун-та, 2004. 417 с.

2. Акофф Р. Л. Планирование будущего корпорации : пер. с англ. М. : Прогресс, 1985. 327 с.

3. Акофф Р. Л., Магидсон Дж., Эддисон Г. Дж. Идеализированное проектирование. Какпредотвратить завтрашний кризис сегодня. Создание будущего организации : пер. с англ. Днепропетровск : Баланс Бизнес Букс, 2007. 265 с.

4. Анализ цифровых образовательных ресурсов и сервисов для организации учебного процесса школ / И. А. Карлов, Н. М. Киясов, В. О. Ковалев, Н. А. Кожевников, Е. Д. Патаракин, И. Д. Фрумин, 
А. Н. Швиндт, Д. О. Шонов ; Национальный исследовательский университет «Высшая школа экономики», Институт образования. М. : НИУ ВШЭ, 2020. 72 с. (Современная аналитика образования. № 10(40).

5. Асмолов А. Г., Шехтер Е. Д., Черноризов А. М. Преадаптация к неопределенности: непредсказуемые маршруты эволюции. М. : Акрополь, 2018. 212 с.

6. Аузан А. А. «Эффект колеи». Проблема зависимости от траектории предыдущего развития эволюция гипотез / Вестн, Моск. ун-та. Сер. 6. Экономика. 2015. № 1. С. 3-16.

7. Бахтин М. М. Проблемы творчества Достоевского. Проблемы поэтики Достоевского. Киев : NEXT, 1994. 509 c.

8. Бёрджес Д. Обучение как приключение. М. : Альпина Паблишер, 2015. 180 с.

9. Гараедаги Дж. Системное мышление. Как управлять хаосом и сложными процессами. Платформа для моделирования архитектуры бизнеса. Минск : Гревцов Букс, 2010. 480 c.

10. Голдсмит М., Рейтер М. Триггеры. М. : Манн, Иванов и Фарбер, 2016.256 с.

11. Гроф С. За пределами мозга. М. : Изд-во Трансперсонального института, 1993.498 с.

12. Гуссерль Э. Избранные работы. М. : Территория будущего, $2012.690 \mathrm{c}$.

13. Душенко К. Нет ничего практичнее хорошей теории // Химия и жизнь. 2020. № 1 [Электронный pecypc]. URL: https://hij.ru/read/26641/ (дата обращения: 12.07.2021).

14. Заиченко Л. И. [и др.]. Проблема трансформации образовательных отношений в начальной школе в условиях цифровизации / Л. И. Заиченко, Н. А. Заиченко, И. Н. Кондратьева, Д. Д. Рубашкин // Перспективы и приоритеты педагогического образования в эпоху трансформаций, выбора и вызовов. VI Виртуальный международный форум по педагогическому образованию : сб. науч. трудов, ч. ІІ. Казань : КФУ, 2020. С. 278-288.

15. Заиченко Н. А. Цифровизация образования как триггер образовательных отношений // Экономика и управление. 2020. № 26(11). С. 1157-1169.

16. Заиченко Н. А., Набокова М. В. Различия в представлениях российской «профессиональной общественности» (массовый респондент) и учителей и родителей отдельно взятой школы (локальный респондент) 0 цифровизации до и во время коронавирусного карантина. Выводы 0 влиянии цифрового образовательного опыта на представления участников образовательных отношений о потенциале и рисках цифровизации общего образования // Народное образование. 2020. № 5(1482). С. 71-80.

17. Иллич И. Освобождение от школ. Пропорциональность и современный мир. М. : Дом Высшей школы экономики, 2006 [Электронный ресурс]. URL: https://royallib.com/book/illich_ ivan/osvobogdenie_ot_shkol_proportsionalnost_i_sovremenniy_mir.html (дата обращения: 12.07.2021).

18. Капра Ф. Дао физики. СПб. : Орис, 1994. 304 с.

19. Концепция модернизации общего образования. Без лозунгов, призывов и наставлений, но сответами на вопросы: Что надо делать? Почему это надо делать? Как это можно сделать? / Л. Л. Любимов ; Национальный исследовательский университет «Высшая школа экономики», Институт образования. М. : НИУ ВШЭ, 2020.80 с. (Современная аналитика образования. № 2(32)).

20. Краевский В. В. Методология педагогики: пособие для педагогов-исследователей. Чебоксары : Изд-во Чувашского государственного университета, 2001. 244 с.

21. Краевский В. В., Бережнова Е. В. Методология педагогики: новый этап : учеб. пособие для студ. вузов. М. : Академия, $2006.400 \mathrm{c}$.

22. Лао-цзы. Трактат о Пути и Потенции // Антология даосской философии. М. : Тов. «Клышников Комаров и Ко», 1994. С. 23-65.

23. Лебедев О. Е. Отношения в системе образования: возможности управления // Человек и образование. 2020. № 3(64). С. 4-10.

24. Мау В. А. Экономика непредсказуемости: на пути к новой парадигме // Образовательная политика. 2020. № 1(81). С. 8-11.

25. Медоуз Д. Азбука системного мышления. М. : Манн, Иванов и Фарбер, 2018. 320 с. 
26. Налимов В. В. В поисках иных смыслов. М. : Прогресс, 1993. 280 с.

27. Ницше Ф. Ессе Ното (автобиография) // Избранные произведения. Книга вторая. М. : Сирин, 1990. C. 327-415.

28. Образование для сложного общества. M. : Global Education Futures, 2018. 212 c.

29. Образовательные экосистемы: возникающая практика для будущего образования. М. : Московская школа управления Сколково; Global Education Futures, 2020. 170 c.

30. О'Коннор Дж., Макдермот И. Искусство системного мышления: необходимые знания о системах и творческом подходе к решению проблем. М. : Альпина Бизнес Букс, 2008. 256 с

31. Оруэлл Дж. 1984. М. : Эксмо, 2021.330 с.

32. Переход общеобразовательных школ на дистанционное обучение в условиях пандемии коронавируса: организационно-педагогический аспект. Практика дистанционного образования, в том числе в условиях пандемии / А. В. Мендель ; Национальный исследовательский университет «Высшая школа экономики», Институт образования. М.: НИУ ВШЭ, 2020. 24 с. (Факты образования. № 9(34)).

33. Писаренко И. А., Заиченко Л. И. Родители как субъекты влияния на развитие цифровых навыков детей // Интеракция. Интервью. Интерпретация. 2021. T. 13. № 2 C. 54-80. D0l: https://doi. org/10.19181/inter.2021.13.2.4

34. Полтерович В. М. Институциональные ловушки и экономические реформы / Российская экон. школа. М., 1998. 42 с.

35. Поппер К. Открытое общество и его враги. Т. 1 «Чары Платона». М. : Феникс, 1992. 448 с.

36. Проблемы перехода на дистанционное обучение в Российской Федерации глазами учителей / Д. И. Сапрыкина, А. А. Волохович ; Национальный исследовательский университет «Высшая школа экономики», Институт образования. М. : НИУ ВШЭ, 2020. 32 с. (Факты образования. № $4(29))$.

37. Прикот О. Г. Лекции по философии педагогики. СПб. : TVP incorporated, 1998. 163 с.

38. Прикот О. Г. Методологические основания педагогической системологии : дис. ... д-ра пед. наук. СПб., 1997. $303 \mathrm{C}$.

39. Прикот О. Г. Методология выбора стратегии развития пространства повышения квалификации педагогических работников в регионе // Человек и образование. 2020. № 4(65). С. 4-12.

40. Прикот О. Г. Методология проектного управления в образовательной организации // Казанский педагогический журнал. 2018. № 6(131). С. 25-30.

41. Прикот О. Г. Обоснование проектного управления в образовании: триггеры и готовность руководителей // Человек и образование. 2019. № 4. С. 4-10.

42. Прикот 0. Г. Об эстетических началах постмодернистской педагогики. Откровения. СПб. : TVP incorporated, $2000.518 \mathrm{c}$.

43. Прикот О. Г. Педагогика отождествления и педагогическая системология. СПб.: TVP incorporated, 1995.260 c.

44. Сендж (Сенге) П. Пятая дисциплина. Искусство и практика самообучающихся организаций. Харьков, 2006. 384 C.

45. Толкин Дж. Р. Р. Властелин колец. М. : АСТ, 2016. 1184 с.

46. Трудности и перспективы цифровой трансформации образования. М. : Издательский дом Высшей школы экономики, 2019.344 с.

47. Уайльд 0. Кисть, перо и отрава. Собрание сочинений. СПб. : Т00 Бионт, 1994. 482 с.

48. Учащиеся начальных классов и их педагоги в цифровой среде / К. А. Адамович, А. В. Капуза, А. А. Горбунова ; Национальный исследовательский университет «Высшая школа экономики», Институт образования. М. : НИУ ВШЭ, 2020. 32 с. (Факты образования. № 5(30)).

49. Хёйзинга Й. Homo Ludens. Человек играющий. М. : Азбука Аттикус, 2019. 440 с.

50. Цифровая трансформация и сценарии развития общего образования / А. Ю. Уваров ; Национальный исследовательский университет «Высшая школа экономики», Институт образования. М.: НИУ ВШЭ, 2020. 108 с. (Современная аналитика образования. № 16(46)). 
51. Цыплят по осени считают: уроки COVID-19 для школ / И. В. Абанкина, А. А. Вавилова, К. В. Зиньковский, К. А. Семенова, Н. Е. Суркова ; Национальный исследовательский университет «Высшая школа экономики», Институт образования. М. : НИУ ВШЭ, 2020. 52 с. (Современная аналитика образования. № 14(44)).

52. Шляйхер А. Образование мирового уровня. Как выстроить школьную систему XXI века? М. : ФИОКО, 2019. $454 \mathrm{c}$.

53. Granovetter M. S. The Strength Of Weak Ties // The American Journal of Sociology. 1973. №. 78 (6). P. $1360-1380$.

54. Hannon V., Patton A., Temperly J. Developing an Innovation Ecosystem for Education // Cisco White Paper. 2011 [Электронный ресурc]. URL: https://www.cisco.com/c/dam/en_us/solutions/industries/docs/ education/ecosystem_for_edu.pdf (date of access: 13.04.2020).

55. Mc Crindle M. The Power of Good. Hibrid Publishers, 2020.190 p.

56. McCrindle M., Fell A. Generation Alpha [Электронный ресурс]. URL: https://mccrindle.com.au/insights/ blog/gen-alpha-defined/ (date of access: 12.07.2021).

\section{Аудио- и видеоисточники}

57. Заиченко Н. А. Институциональные основы образовательной политики : онлайн-курс, 2021.

58. Прикот О. Г. Стратегическое управление в образовании: методология и кейсы проектных решений : онлайн-курс [Электронный ресурc]. URL: https://openedu.ru/course/hse/STRATED/ (дата обращения: 10.07.2021).

59. Полтерович В. Институциональные ловушки : видеолекция [Электронный ресурc]. URL: https:// www.youtube.com/watch?v=EZMV1MALw60 (дата обращения: 02.07.2021).

60. Робертс К. Менеджмент умер. Маркетинг умер. Стратегия умерла : видеоконспект лекции [Электронный ресурc]. URL: https://www.youtube.com/watch?v=61wwXaVXH9M\&t=2s (дата 06ращения: 12.07.2021).

61. Робинсон К. Новый взгляд на систему образования : видеолекция [Электронный ресурс]. URL: https://www.youtube.com/watch?v=13j8aT6Fedw\&t=2s (дата обращения: 12.07.2021).

62. Седьмая печать : х/ф/ реж. Ингмар Бергман ; Janus Films. 1957 [Электронный ресурc]. URL: https:// yandex.ru/video/preview/?text= седьмая печать фильм 1957 смотреть онлайн в хорошем качестве бесплатно \&path=wizard\&parent-reqid=1626537113994426-9992757575890671665-vla14657-vla-17-balancer-prod-8080-BAL-9334\&wiz_type=vital\&filmld=622952163142072590 (дата обращения: 12.07.2021). 
Раздел II

ТЕОРИЯ 



\section{ГЛАВА 2}

\section{Цифровизация образования как смена образовательных ритуалов}

Актуальный тренд развития системы образования - цифровизация образования меняет парадигму образовательных отношений и задает вектор трансформации в управлении образованием: от управления, ориентированного на результаты обучения, к управлению образовательными отношениями, то есть управлению процессом.

Изменения привычных ритуалов в образовательных отношениях стали очевидными весной 2020 г., что обусловлено экзогенными факторами «черными лебедями» (в терминологии Нассима Талеба) от COVID-1955. Данное явление является уникальным в контексте трансформации отношений и выхода за пределы аналогового мира «офлайн» в мир «онлайн».

Участники образовательных отношений, являясь агентами изменений этих отношений, формируют определенное состояние общества в целом и его готовность к изменениям. Люди школы, как влиятельные участники образовательных процессов, могут создавать новые взаимодействия и модифицировать мир образования.

Собственно дефиниция «цифровизация образования» имеет множество трактовок, и в настоящее время в профессиональном сообществе не достигнут консенсус в этом вопросе. Мы предлагаем собственную трактовку дефиниции «цифровизация образования», анализируем некоторые подходы к расшифровке понятия «цифровая трансформация». Делаем попытку аргументировать свой выбор.

В контексте темы исследования, проводимого в рамках гранта фонда РФФИ по теме «Управление развитием образовательных отношений субъектов в начальной школе в условиях цифровизации», развитие образовательных отношений рассматривается через феномен изменений (трансформации). Статус «фундаментального исследования» по гранту налагает ответственность за поиск фундаментальных оснований для объяснения происходящих изменений во взаимодействиях между участниками образовательных отношений в условиях цифровизации и приводит к формулировке цели - нащупывания релевантных теорий, объясняющих явление цифровой трансформации как смену образовательных ритуалов.

В этом контексте и возникает исследовательская проблема - поиск объективного измерителя или объясняющей теории изменений в образовательных отношениях в новой нормальности - в цифровой реальности.

5 COVID-19 (от англ. COrona VIrus Disease 2019; ранее - коронавирусная инфекция 2019-nCoV) - наименование вирусного возбудителя (коронавируса) и вызываемого им заболевания. 
Теоретическая рамка базируется на междисциплинарном подходе: общей теории систем; социологическом, антропологическом и психолого-педагогическом подходах.

Исследовательский метод можно отнести к методу дедукции через «нащупывание» релевантных теорий: от теории социальных изменений и социального действия к теории «зоны ближайшего развития» обучающихся.

В рамках исследования закрепляются термины «образовательные ритуалы» — как образовательное поведение участников образовательных взаимодействий, происходящее в рамках определенных формальных и неформальных правил, и «учебные ритуалы» - как система символического поведения в отношениях субъектов учебного процесса для достижения заданных учебных результатов.

\section{1. Введение в проблему}

Изменчивость и неопределенность мира при консервации учебных ритуалов в образовательных отношениях, акценты на обновление, декларируемые в документах национального проекта «Образование», при догоняющем состоянии школьной системы позволяют заявить, что для развития школы необходимо делать ставку не только на профессиональные знания и опыт педагогов и лидеров школьного образования, но и на их возможности и желание постоянно меняться для решения новых задач и инициировать сами изменения. По смыслу противоречий дискурс сосредоточен на дефиците такой

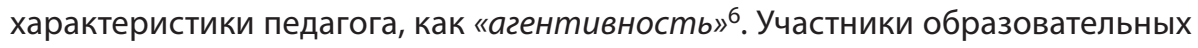
отношений, являясь агентами изменений этих отношений, формируют определенное состояние общества в целом и его готовность к изменениям. Именно так люди школы могут создавать новые взаимодействия и модифицировать мир образования, мир человека.

С одной стороны, действия людей школы детерминированы прежними структурами взаимодействий, рутинами, привычными ритуалами, законсервированными нормами и правилами. С другой стороны, мир неопределенности с эффектами «черных лебедей» предлагает новые вызовы и вместе с ними риски повреждения привычных, комфортных отношений, интеллектуальный страх перед нестандартным и неизбежным событием. «Понять, как сделаться нечувствительным к повреждению от переменчивости, легко; предсказать событие, которое приведет к повреждению, намного сложнее» [Талеб].

Одним из таких событий, провоцирующих «повреждения», в терминологии Нассима Талеба, является ситуация массового перевода системы образования (на всех уровнях) в онлайн-форматы как наиболее яркого и точного сигнала, раскрывающего понимание феномена цифровизации образования и явления изменения учебных ритуалов. Выход на онлайн-обучение актуализировал проблему изменений в образовательных отношениях и достиг своего пика к весне 2020 г., обусловленный экзогенными факторами — «черными лебедями» [Казакова; Исаева; Заиченко, Набокова; Оборин], связанными с явлением COVID-19.

«COVID-феномен» в контексте человеческих отношений, образования в частности, уже стал темой отдельных исследований и обсуждений и в даль-

\footnotetext{
6 См. главу 4 данной монографии.
} 
нейшем потребует особого изучения. Этот феномен сам по себе является уникальным в контексте трансформации отношений в любой сфере деятельности человека и выхода человеческих отношений за пределы аналогового мира «офлайн» в мир «онлайн». Развивается новый вид отношений, возникает расширяющееся поле выборов и ограничений одновременно [Казакова; Кузьминов] как в системе образования, так и в частной жизни; наблюдаются разнообразные форматы коммуникаций, которые в конечном счете и являются фундаментом образовательных отношений. Замечено, что множественность форм коммуникации без разумных пределов их применения приводит к проблеме размытости и размазанности коммуникаций, слому рациональности поведения, потере ориентиров [Радаев].

Размышления о проблеме трансформации образовательных и учебных ритуалов в данном случае сосредоточены на периоде перехода учебного процесса из аналоговой в цифровую среду. И мы делаем умозрительную попытку презентовать теории, объясняющие процесс изменений в образовательных отношениях в цифровой реальности и аргументировать их объясняющую роль в процессе изменений.

Еще раз акцентируем внимание на том, что дефиниция «цифровизация образования» в экспертном сообществе не находит точного определения и является самостоятельной темой для исследования и согласования позиций. Дискуссии экспертов в данной области позволяют выявить две противоположные точки зрения: с одной стороны - технократический взгляд на цифровизацию [Абрамова; Уваров; Цифровая трансформация...], с другой - нечетко выраженная гуманистическая позиция экспертов. «Технократы» склонны ставить акценты в теме цифровизации образовательной среды на взаимодействии типа «человек - машина» [Обучение цифровым...; Рабочий доклад...], в то время как гуманитарии предпочитают придавать феномену цифровизации поведенческое значение, их взгляд на смыслы цифровизации связан с формированием культуры цифрового поведения участников образовательных отношений. По сути, эти позиции являются взаимодополняющими. Мы понимаем под «цифровизацией образования» формирование отношений между участниками образовательного прочесса как агентами изменений учебных ритуалов в чифровой образовательной среде.

В этой связи возникают контекстные проблемы для постановки исследовательских вопросов:

1) проблема несформированности консенсуса по дефинициям «цифровая трансформация»; «цифровизация образования»; «цифровая образовательная среда»;

2) проблема поиска объективного измерителя или объясняющей теории изменений в образовательных отношениях в новой - цифровой реальности;

3) проблема поиска теории, объясняющей понятие учебных ритуалов.

Поиск, а точнее «нащупывание» ${ }^{7}$, объясняющей теории изменений в образовательных отношениях сфокусирован, с одной стороны, на собственно теоретическом обосновании феномена изменений, с другой стороны ${ }^{8}$,

\footnotetext{
7 Не путать с «теорией нащупывания» Леона Вальраса - здесь нет связи, есть эксплуатация термина.

${ }^{8}$ См. главу 5 данной монографии.
} 
на заимствованном эмпирическом материале из различных источников, подтверждающем проблему размытых представлений людей школы о феномене цифровой трансформации и цифровизации образования.

\section{2. Теоретическая рамка 9}

Теоретическая рамка базируется на междисциплинарном подходе: общей теории систем; социологическом и психолого-педагогическом подходах, социологической антропологии.

Мы склонны придерживаться позиции аналитического реализма [Parsons 1949] и описываем некую идеальную картину отношений в цифровой школе, исходя из Парсонсовского суждения «чтобы понять реальные связи, необходимо создать идеальные типы, то есть связи "нереальные", аналитические» [lbid]. Это тем более оправданно, что в данной монографии есть главы теоретико-эмпирического типа, когда теория проверяется на экспериментальном материале. В нашем случае теория имеет аналитический характер в том смысле, что не является копией реальности, а представляет собой теоретическую реальность.

Мы создаем концептуальную схему, и в качестве теоретической рамки исследования базовыми стали следующие теории:

1) теория социального действия Т. Парсонса [Parsons 1937, 1949];

2) теория «лиминальности» и ритуалов Геннепа и Тернера [Gennep; Turner];

3) теория социальных изменений (типология) социального процесса П. Штомпки [Штомпка; Sztompka];

4) теория «зоны ближайшего развития» Л. С. Выготского [Выготский 1956];

5) теория деятельности и развития А. Н. Леонтьева, С. Л. Рубинштейна [Леонтьев; Рубинштейн].

Логика отбора именно этих теоретических оснований расшифровывается в последующих параграфах.

Исследовательские амбиции автора данной главы, связанные с проблемой поиска аргументированной теории о включении в научный оборот понятия «образовательные ритуалы» и «учебные ритуалы», подстрахованы словами британского антрополога Бронислава Малиновского: «минимальное определение науки выводимо из любого действия, прагматически направленного на достижение результата» [Малиновский].

Включая в дискурс понятие «ритуал», мы исходим из этимологии слова, откуда вытекает, что важнейшей функцией ритуала была (и остается) функция упорядочивания [Артемьева]. Под ритуалом в общем смысле мы понимаем стереотипную последовательность действий, выполняемых в определенных обстоятельствах. Ритуалы, как институты, упрощают социальное поведение человека, стабилизируют взаимодействия, позволяют реагировать на различные внешние воздействия автоматически, не задумываясь над своим действием.

Социологический взгляд на ритуалы сформирован следующим образом: это «любые формальные действия, следующие установленному образцу и выражающие, посредством символа, общественный или общий смысл...

\footnotetext{
9 Первая итерация теоретической рамки: [Заиченко].
} 
понятие ритуала часто используется для обозначения всякого регулярно использующегося образца взаимодействия» [Аберкомби].

Ритуалы ориентированы на любые модели социального поведения человека, формирующие его роли в обществе. Когда в нашем дискурсе появляется слово «урок», в традиционном понимании, сразу возникает картинка этого ритуального процесса: учитель, обладающий «сакральным» знанием, и внемлющий ему ученик. Мы эксплуатируем понятие ритуала именно потому, что цифровая трансформация изменяет стереотипную последовательность действий процесса учения - старые ритуалы рушатся под натиском новых.

В рамках исследования закрепляются термины «образовательные ритуалы» - как образовательное поведение участников образовательных взаимодействий, происходящее в рамках определенных формальных и неформальных правил, и «учебные ритуалы» - как система символического поведения в отношениях субъектов учебного процесса для достижения заданных учебных результатов. В практике отношений это можно сопоставить следующим образом: образовательные ритуалы - это любые виды взаимодействий между субъектами в пространстве школы; учебные ритуалы - это взаимодействия между участниками в процессе конкретного занятия (урок, семинар, проект, практика и пр.). Мы оставляем открытым для дискуссий тезис о том, что в условиях цифровизации нивелируются некоторые функции образовательных и учебных ритуалов и на смену им приходят другие функции, типа академической автономии и «свободы от школ» (по Илличу).

\section{3. Теория социального действия и образовательные роли}

Теория социального действия [Parsons 1937, 1949] рамочно используется нами в контексте суждений автора о проверке того, насколько теоретические ожидания совпадают с найденными фактами, со скидкой на «ошибки наблюдения» и так далее, насколько теория является «верифицированной» [Parsons 1949]. Т. Парсонс выбирает термин «действие», предполагающий осмысленный процесс, активность самого действующего индивида. Парсонс создал две модели социального действия (взаимодействия): «волюнтаристскую» модель единичного действия и кибернетическую концепцию систем действия, включающую четыре основных взаимосвязанных типа: социальная система, культура, личность и организм. Для анализа функций систем действия было предложено четыре функциональных реквизита, известных как схема AGIL (адаптация - цель - интеграция - латентность):

- адаптация (adaptation);

- целедостижение (goal attainment);

- интеграция (integration);

- поддержание латентного образца (latent pattern maintenance).

Первые две функции системы относятся к ее связи с внешней средой, а две другие характеризуют внутреннюю организацию взаимодействия социализированных индивидов. Иначе рассуждая, Парсонсовская парадигма «действия» как концептуальная схема включает четыре компонента, которые образуют систему: 1) наличие действователя, или актора, - 
действующего организма; 2) существование цели, на достижение которой направлено действие актора, - «предполагаемое будущее положение вещей»; 3) наличие ситуации, в которой происходит действие (условия действия, определяемые объективными обстоятельствами, и выбираемые средства для достижения цели); 4) существование нормативной ориентации, то есть усвоенных стандартов поведения.

Парсонс рассматривает систему личности как интегрированную в социальную систему через два механизма: социализацию и социальный контроль (рис. 1).

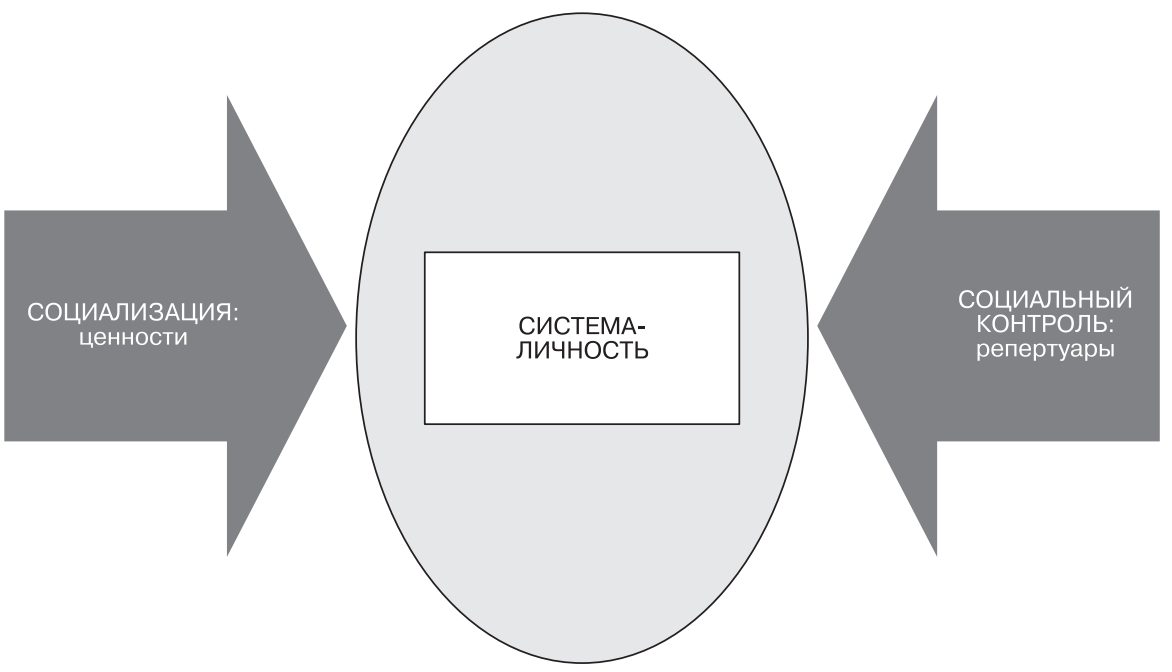

Puс. 1. Система-личность интегрирована в социальную систему

Механизм социализации трактуется как форма усвоения личностью ценностей, убеждений, языка и других символов. Социализированная личность - это личность, усвоившая нормы поведения и ставшая участником социального взаимодействия.

Механизм социального контроля представляет собой систему статусноролевых репертуаров. Социальный контроль позволяет личности использовать стандартные схемы поведения в стандартных ситуациях, что является своеобразной страховкой от «плохих» возможных последствий своего поведения. В социальный контроль включены:

1) институты - стандартные формы взаимных ожиданий; санкции (средства поощрения и наказания);

2) ритуалы - символические средства для выражения своих мотивов и ожиданий:

3) средства безопасности - социальные формы изоляции отклонений от нормального институционального образца;

4) реинтегративные структуры - организации, корректирующие отклонение и управляющие социализацией (например, тюрьмы и школы);

5) средства физического принуждения.

Если Парсонсовскую модель социального контроля переложить на школу, то получим некую аналоговую модель социального контроля в школе (табл. 1). 
Аналоговые статусно-ролевые репертуары в образовательных отношениях, по теории Парсонса

\begin{tabular}{|c|c|}
\hline $\begin{array}{l}\text { Статусно-ролевые репертуары } \\
\text { социального контроля по Парсонсу }\end{array}$ & $\begin{array}{c}\text { Аналоговые статусно-ролевые репертуары } \\
\text { в школьном образовании }\end{array}$ \\
\hline $\begin{array}{l}\text { Институты, в том числе: } \\
\text { • позитивные санкции; } \\
\text { • негативные санкции }\end{array}$ & $\begin{array}{l}\text { 1) Модель оценивания учебных достижений может являться как } \\
\text { позитивной, так и негативной в зависимости от включенных } \\
\text { критериев; } \\
\text { 2) система аттестации педагогов может мотивировать на до- } \\
\text { стижения, а полученная категория стимулируется позитивной } \\
\text { санкцией — повышением оклада; } \\
\text { 3) педагог, включенный в процесс цифровизации обучения, } \\
\text { может быть поддержан позитивной санкцией (деньги, слава, } \\
\text { преференции, репутация инноватора), а может быть не включен } \\
\text { в поле внимания администрации и коллектива, что равносильно } \\
\text { негативной санкции }\end{array}$ \\
\hline $\begin{array}{l}\text { Ритуалы для выражения мотивов } \\
\text { и ожиданий }\end{array}$ & $\begin{array}{l}\text { Ритуалы: } \\
\text { 1) публичное выражение благодарности за качественную работу; } \\
\text { участие в инновационном движении; участие в проектах цифро- } \\
\text { визации; } \\
\text { 2) типичный перечень действий со стороны учителя и ученика } \\
\text { при сдаче экзаменов; } \\
\text { 3) обращение ученика к учителю (или необращение) в ожидании } \\
\text { помощи со стороны учителя (или неожидание) при трудностях, } \\
\text { возникающих при решении задания }\end{array}$ \\
\hline $\begin{array}{l}\text { Средства безопасности при отклонении } \\
\text { от норм }\end{array}$ & $\begin{array}{l}\text { 1) Отчисление из образовательной организации за несоблюдение } \\
\text { необходимых норм или неуплату; } \\
\text { 2) увольнение из организации по инициативе работодателя; } \\
\text { 3) уменьшение педагогической нагрузки, что влечет за собой } \\
\text { уменьшение зарплаты }\end{array}$ \\
\hline Реинтегрированные структуры & $\begin{array}{l}\text { 1) Администрация школы; } \\
\text { 2) конфликтная комиссия в образовательной организации; } \\
\text { 3) психолого-педагогическая служба; } \\
\text { 4) организации для детей с девиантным поведением }\end{array}$ \\
\hline Средства физического принуждения & $\begin{array}{l}\text { На уровне школы отсутствуют. } \\
\text { На уровне неформальных норм могут присутствовать и в детских, } \\
\text { и во взрослых (родительских) коллективах }\end{array}$ \\
\hline
\end{tabular}

Участники образовательных отношений, даже ориентированные на различные ценности и цели, вынуждены согласовывать свои действия в определенных ситуациях. Способ координации действий определяется усвоенными культурными «паттернами». В процессе взаимодействия формируются нормы, включающие в себя устойчивые ожидания относительно действий участников ситуации.

Роли, которые «играются» участниками, в нашем случае участниками образовательных взаимодействий, должны быть «социально оперативными»тогда взаимодействие будет выполнять надлежащую функцию, будет функциональным. Но это происходит только тогда, когда эта роль усвоена участниками ситуации личностно. Так, например, роль учителя в системе оцифрованных отношений в модели «ученик - учитель» меняется кардинально. Учитель уже не единственный режиссер образовательного спектакля, появилась великая 
информационная сила Интернета, и учитель должен примерять на себя роль «оператора» во взаимодействии «ученик - Интернет - учитель». Работа с потоками информации пришла на смену формированию запаса знаний. И это значит, что традиционные «уроки» не вызывают никакого интереса, и если учитель по-прежнему играет роль режиссера, обладающего сакральным знанием о сути спектакля, то образовательная сила спектакля существенно падает. Учитель не «вживается» личностно в новую роль, ученик теряет интерес к той роли, которую ему навязывают, в результате индивидуальные ожидания сторон не актуализируются, не распознаются. В идеале должна произойти такая трансформация образовательных отношений, которая переведет систему на модель эквивалентного обмена действиями (по Парсонсу), что «предполагает согласованное определение ситуации всеми ее участниками, которое есть не что иное, как взаимно ориентированное подкрепление, - никаких других норм и санкций здесь не требуется. Поэтому система ролевых отношений является саморегулирующейся» [Parsons 1949].

Нет сомнений в том, что цифровизация переводит школу в новую культуру взаимодействий, которая требует изменений «образца».

На этот счет у Парсонса есть любопытная идея о первой модернизационной трансформации, связанной с возникновением письма. Письмо, как внешняя форма речи, дает возможность «объективировать» ценности и идеи, то есть отделить их от носителей и тем самым придать им безличную форму нормативного образца.

Можно поэксплуатировать эту идею и переложить ее на феномен интернетизации образования, которая так же деперсонифицирует информационное поле образования и позволяет распространить культурные образцы (ценности и нормы) на широкие группы людей. В этом случае «цифра» (как и письмо в «кейсе» Парсонса) становится источником накопления и систематизации новой образовательной культуры, производства знания, профессиональной специализации, триггером для формирования новых ролевых репертуаров для всех участников образовательных отношений. И еще один существенный акцент: цифровая трансформация (по аналогии с возникновением письма) приводит в действие объективный процесс автономизации личности с доминирующим местом не для внешних, а для внутренних норм. Распознавание этих внутренних норм - дорожная карта для персонализированной модели образования. И лучше всего с этой ролью уже сегодня может справляться человек, использующий «цифру» - технологию «цифрового следа».

Итак, теория социального действия Парсонса дает нам некоторые основания для предварительных выводов в контексте цифровизации образования:

1) цифровизацию образования можно рассматривать как социальное действие в том случае, если участники образовательных отношений личностно усвоили свои новые роли;

2) успешность цифровой трансформации образования возможна:

- при условии перехода на модель эквивалентного обмена действиями между всеми участниками образовательных отношений, то есть на саморегулирующуюся систему ролевых отношений;

- при наличии механизмов социального контроля как системы статусно-ролевых репертуаров;

3) адекватность управления процессом цифровой трансформации определяется его настройкой на социальное действие, и на уровне образовательной организации управление должно формироваться (учиты- 
вать) по четырем «реквизитам» схемы AGIL: адаптация - целедостижение — интеграция — поддержание латентного образца (рис. 2).

ВНЕШНЕЕ ВОЗДЕЙСТВИЕ
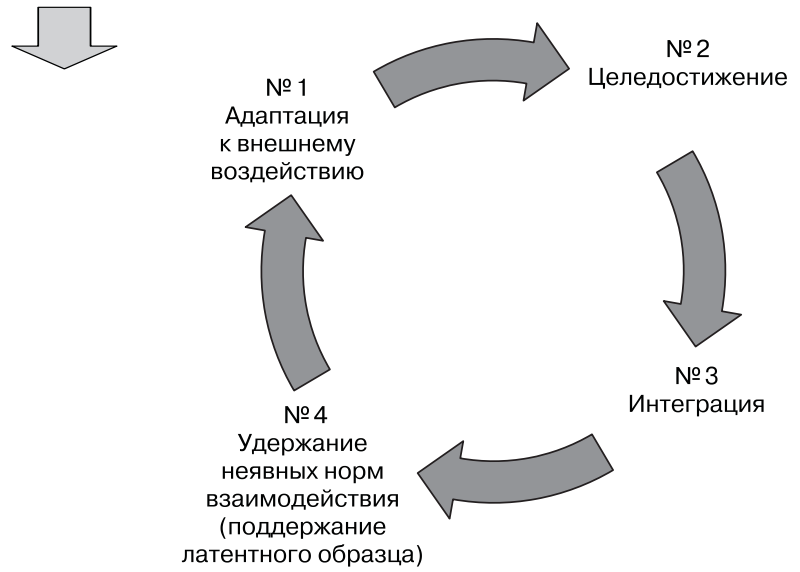

Puc. 2. Схема AGIL в контексте цифровой трансформации

\section{4. Теория «лиминальности» и ритуалы}

Изменчивость мира и перманентность кризисных состояний в образовании с неизбежностью подводят нас к использованию теории лиминальности как объясняющей теории процесса трансформации отношений. Феномен трансформации отношений в цифровой образовательной среде мы рассматриваем через призму теории лиминальности, то есть перехода отношений из привычного состояния в новое, при этом наблюдается потеря прежних статусов (ролей) в отношениях субъектов, нивелируется понимание иерархии в структуре «ученик - учитель».

Авторы понятия «лиминальность» [Gennep; Turner] включали три стадии в ритуал перехода:

1) отделение (separation) - как лишение индивида прежних статусных характеристик;

2) собственно переход (transfer) - как некое переходное состояние;

3) реконструкция (reconstruction) - конструирование новой системы отношений.

Ритуал перехода, по мнению Геннепа [Gennep], является обязательным атрибутом изменений любого уровня и типа (страны, места, социального статуса, ролевой позиции) и присущей этому переходу дихотомией между «устойчивой» и «переменной» структурами. Лиминальность включает множество изменений: социального статуса, ценностей и норм, идентичности (identity) и самосознания, осмысления и понимания, сознания, языковой практики. По своему смыслу вторая фаза - фаза трансфера, или собственно лиминальности, - это транзит между стабильной и трансформирующейся структурами.

В контексте школы примером лиминальности может являться переход от традиционной классно-урочной структуры образовательных отношений к структуре внеклассной, например цифровой или потоковой. По аналогии 
с ритуалом «перехода» можно выделить три этапа в процессе трансформации в образовательных отношениях при переходе «в цифру»:

1) традиционные классно-урочные «вертикальные» образовательные отношения «ученик - учитель», «учитель - родитель» актуализируются в виртуальном пространстве, меняя статусные роли всех участников образовательных отношений;

2) появляются новые нормы коммуникаций - взаимодействие через цифровое пространство (в том числе искусственный интеллект) посредством гаджетов, виртуальная постоянная (системная) обратная связь;

3) конструируются способы адекватного использования новых норм взаимодействий и новых возможностей в этих отношениях.

Феномен лиминальности особенно интересен применительно к осмыслению процессов, происходящих в трансформирующемся обществе. Более того, лиминален вообще любой процесс изменения [Тульчинский].

Дополняя Геннепа, Тернер особое внимание уделяет лиминальной фазе, выполняющей функцию порога, отделяющего друг от друга разные этапы жизни и деятельности.

Мы рассматриваем теорию лиминальности как адекватную по отношению и к отдельной личности, и к организации в целом. Стадию лиминальности личности можно описать следующим примером: период обучения в вузе - это промежуточная, лиминальная стадия перехода из мира ученичества в мир специалиста. Модельная версия такого транзита проходит через несколько фаз, и некоторые из них являются ритуальными: сдача ЕГЭ - поступление в вуз - учеба в вузе - аттестация в вузе (защита выпускной работы) - выход на рынок труда. Ритуал перехода из ученичества в трудовую деятельность универсален, даже если количество фаз перехода меняется, например, если выпадает фаза получения профессионального образования, в любом случае этот ритуал представляет собой «умирание» индивида в роли ученика и «воскрешение» в роли специалиста.

Позаимствуем образное выражение лиминальности [Фусу]: «это состояние неопределенности или дезориентации, которое появляется в центральной части ритуала перехода, когда участники ритуала выходят из предстоящего статуса, но еще не обретают новый. Во время лиминальной стадии участники ритуала „стоят на пороге“ между предыдущим способом структурирования собственной идентичности, времени, общества - и новым, который будет установлен с помощью ритуала».

Разве не то же самое происходит при переходе в цифровое пространство образования?

Фаза лиминальности осязаемо может быть скоротечной (как, например, это произошло при переходе системы школьного образования из офлайн в онлайн в период пандемии весной 2020 г.), но понимание, осмысление, структурирование собственной идентичности как ученика и родителя, так и учителя не происходят быстро и требуют времени на адаптацию к новым нормам отношений и согласования этих новых норм в организации (см. рис. 2).

Мы держим рамку «организации», так как школьное образование все еще «не освободилось от школ», по образному выражению И. Иллича [Иллич], и, базируясь на форматах классно-урочной системы в организации, педагоги переносят старые форматы обучающих коммуникаций на новые онлайн-технологии. Существенным дополнением к интерпретации результатов исследования, пониманию смысла исследования, объектом которого объявлен 
феномен «трансформации отношений», является для нас замечание «философа нестабильности» И. Пригожина: «неустойчивости могут возникнуть в любой системе, стоит лишь ввести подходящие возмущения» [Пригожин]. И в этом смысле цифровизация образовательного пространства может способствовать формированию неустойчивых и быстро изменяющихся форматов образовательных отношений, когда в любой момент времени может возникнуть новый тип отношений, не сводимый к предыдущим, и «точки» смены типов отношений можно определить как «точки бифуркации», которые трансформируют образовательное пространство в целом.

Наш фокус на теории социальных изменений [Штомпка; Sztompka] ocoбенно важен в ситуации зимы - весны 2020 г. Экзогенно сформированный источник трансформации межличностных отношений ${ }^{10}$ с выходом из реальной в виртуальную среду отражается на системе образования эффектом матрешки, «двойным отбором»: трансформируется поле взаимоотношений и на глобальном уровне, общества в целом, и на локальном уровне отдельных школ и классов. И в этой связке наше исследование по «трансформации образовательных отношений в условиях цифровизации» приобретает дополнительный вектор для наблюдения на последующих этапах.

Школу как организацию мы определяем как «мягкое поле взаимоотношений» [Штомпка].

В теоретическую рамку объясняющих теорий теория социальных изменений включена для использования понятия «межличностного поля» и наблюдения за процессом цифровой трансформации не только школы, но общества в целом, которое базируется, по Штомпке ${ }^{11}$, на четырех базовых и двух дополнительных критериях (табл. 2).

Таблица 2

Критерии процесса социальных изменений П. Штомпки в контексте цифровизации образования

\begin{tabular}{|c|c|c|}
\hline $\begin{array}{l}\text { Наименование } \\
\text { критерия } \\
\text { по Штомпке }\end{array}$ & Расшифровка критерия & $\begin{array}{c}\text { Комментарии, контекстные процессу } \\
\text { цифровизации }\end{array}$ \\
\hline 1 & 2 & 3 \\
\hline Форма процесса & $\begin{array}{l}\text { - Направленный процесс, т. е. необратимый, } \\
\text { то, что нельзя «повернуть вспять»; может } \\
\text { быть постепенным и/или скачкообразным; } \\
\text { - } \quad \text { ненаправленный процесс }\end{array}$ & $\begin{array}{l}\text { Цифровая трансформация - направлен- } \\
\text { ный процесс, однако на уровне школы в } \\
\text { лиминальном периоде он может прохо- } \\
\text { дить как постепенно, так и скачкообразно }\end{array}$ \\
\hline Результат процесса & $\begin{array}{l}\text { - } \quad \text { Морфогенез, т. е. результат приводит к } \\
\text { фундаментальным изменениям; } \\
\text { - } \quad \text { трансмутация, когда происходят незна- } \\
\text { чительные изменения, модифицирующие } \\
\text { отношения. } \\
\text { Можно различать: } \\
\text { - } \quad \text { трансформация — синоним к «изменение } \\
\quad \text { чего-либо»; } \\
\text { репродукция - указывает на изменение } \\
\text { внутри чего-либо }\end{array}$ & $\begin{array}{l}\text { Цифровая трансформация приводит к } \\
\text { фундаментальным изменениям и может } \\
\text { быть отнесена к типу морфогенеза, по- } \\
\text { рождает новые формы коммуникации, } \\
\text { новые возможности для образовательной } \\
\text { аналитики (цифровой след), новые обра- } \\
\text { зовательные отношения через цифровые } \\
\text { форматы и обучающие технологии и пр. }\end{array}$ \\
\hline
\end{tabular}

10 Объявленные по странам «статусы» жизни населения в условиях «самоизоляции», «карантина», «чрезвычайной ситуации» и пр.

11 П. Штомпка при описании критериев процесса изменений дает ссылки на терминологию Мертона и Кендалл, см.: Merton R. K., Kendall P. L. The Boomerang Response // Channels. National Publicity Council for Health and Welfare Service. 1944. V. 21. P. 1-7. 
Окончание табл. 2

\begin{tabular}{|c|c|c|}
\hline 1 & 2 & 3 \\
\hline $\begin{array}{l}\text { Возможность } \\
\text { осведомленности } \\
\text { населения о ре- } \\
\text { зультатах процесса } \\
\text { изменений }\end{array}$ & $\begin{array}{l}\text { - } \\
\text { Явные процессы, которые можно распоз- } \\
\text { нать, выявить цель, предсказать; } \\
\text { латентные (неявные) процессы, когда } \\
\text { результаты изменений возникают не- } \\
\text { ожиданно и их нельзя сразу воспринять как } \\
\text { положительные или отрицательные; } \\
\text { процесс-бумеранг, когда изменения } \\
\text { происходят вопреки ожиданиям и планам } \\
\text { «с точностью до наоборот» }\end{array}$ & $\begin{array}{l}\text { Разные типы участников образователь- } \\
\text { ных отношений находятся в разной } \\
\text { степени осведомленности о процессах } \\
\text { цифровизации образования. } \\
\text { Все виды процессов по уровню про- } \\
\text { зрачности их результатов (явные, ла- } \\
\text { тентные, бумеранги) возможны в разных } \\
\text { школах в период лиминальности }\end{array}$ \\
\hline $\begin{array}{l}\text { Движущие силы } \\
\text { процесса изме- } \\
\text { нений }\end{array}$ & 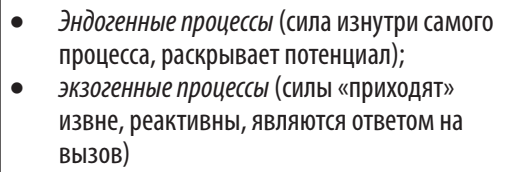 & $\begin{array}{l}\text { Стартовый уровень цифровизации - } \\
\text { экзогенный, последующий уровень } \\
\text { возможен как эндогенный (зависит от } \\
\text { временных рамок, в которых изучается } \\
\text { процесс цифровизации) }\end{array}$ \\
\hline \multicolumn{3}{|c|}{ Дополнительные критерии } \\
\hline $\begin{array}{l}\text { Уровень социаль- } \\
\text { ной реальности }\end{array}$ & $\begin{array}{l}\text { - Макроуровень по типу «дурной бесконеч- } \\
\text { - } \quad \text { мости» (уровень мира, страны, региона); } \\
\text { ства, ассоциациии, политические партии, } \\
\text { армия, бюрократия); } \\
\text { - } \quad \text { микроуровень (в повседневной жизни } \\
\text { человеческих индивидов: в малых группах, } \\
\text { семьях, школах, объединениях по роду } \\
\text { занятий, дружеских кружках) }\end{array}$ & $\begin{array}{l}\text { Процесс цифровизации захватывает все } \\
\text { уровни социальной жизни }\end{array}$ \\
\hline $\begin{array}{l}\text { Временно́й аспект } \\
\text { рассматриваемого } \\
\text { процесса }\end{array}$ & $\begin{array}{ll}\text { - } & \text { Крайне короткие, мгновенные; } \\
\text { - } & \text { быстротекущие; } \\
\text { - } & \text { долговременные («эпохальные») }\end{array}$ & $\begin{array}{l}\text { Процесс цифровизации образования от- } \\
\text { носительно долговременный, если ори- } \\
\text { ентироваться на территорию страны, и } \\
\text { может быть быстротекущим для уровня } \\
\text { организации. } \\
\text { Во времени процесс цифровых изме- } \\
\text { нений разделяется на два типа цифрового } \\
\text { неравенства: } \\
\text { - неравенство технического оснаще- } \\
\text { ния школ; } \\
\text { неравенство цифровых компетен- } \\
\text { ций участников образовательных } \\
\text { отношений }\end{array}$ \\
\hline
\end{tabular}

Штомпка уточняет понятие «межличностного поля» в типологии ИНИВ 12 (идеальное, нормативное, интеракционное и возможное). Эта типология «пригодится» нам для наблюдения и выявления реальных взаимосвязей между участниками образовательных отношений в проводимом эксперименте по управлению образовательными отношениями в условиях цифровизации ${ }^{13}$.

Формулируем контекстные выводы, исходя из понимания концепта «ритуал», теорий лиминальности и социальных изменений:

1) цифровая трансформация изменяет ритуалы как стереотипную последовательность действий в образовательных отношениях. В рамках исследования закрепляются термины «образовательные ритуалы» — как образовательное поведение участников образовательных взаимодействий, происходящее в рамках определенных формальных и неформальных правил, и «учебные ритуалы» - как система символического

\footnotetext{
12 В оригинале это аббревиатура INIO (ideal, normative, interactional, opportunity).

13 В данной монографии теме эксперимента посвящен раздел IV.
} 
поведения в отношениях субъектов учебного процесса для достижения заданных учебных результатов;

2) современный процесс цифровизации образования фиксируем как период лиминальности, с учетом того, что для разных школ и уровней образования достигнуты разные фазы лиминальности, при этом фаза реконструкции образовательных отношений не наступила;

3) процесс цифровой трансформация является направленным (то есть необратимым) процессом; в лиминальном периоде может проходить как постепенно, так и скачкообразно; стартовый период стимулируется экзогенно; результаты приводят к фундаментальным изменениям образовательных отношений.

\section{5. Зоны ближайшего развития и деятельность}

Две последующие теории выделены в силу их смысловой непротиворечивости предыдущим авторам и исследовательским подходам и включены в теоретическую рамку в качестве концепта для объяснения возможных и необходимых изменений в отношениях между участниками образовательного процесса.

Популярность и широкое использование трудов Л. Выготского и А. Леонтьева в отечественных и зарубежных исследованиях психолого-педагогической направленности подсказывают возможность краткого изложения аргументов, по которым мы включаем основные положения теорий этих выдающихся ученых, контекстные нашему исследованию.

Мы выбираем базовые для экспериментальной части исследования концепты: 1) «зоны ближайшего развития» и 2) «деятельностная» теория — и эксплуатируем в целях объяснения некоторых результатов экспериментальной части нашего исследования ${ }^{14}$.

Так как наш дискурс цифровизации постоянно апеллирует к теме социальных изменений, логично обратиться к словам Л. Выготского о том, что социальная ситуация развития - это специфическая для каждого возраста система отношений между ребенком данного возраста и социальной действительностью, которая «определяет строго закономерно весь образ жизни ребенка, или его социальное бытие» [Выготский 1984]. И это означает, что те фундаментальные изменения, которые реально происходят в образовательных отношениях в условиях цифровизации, диктуют новую социальную ситуацию развития.

«Зоны ближайшего развития» Л. Выготского [Выготский 1956, 2005] и «деятельностная» ${ }^{15}$ теория А. Леонтьева [Леонтьев] помогают выстроить логику наблюдения за поведением обучающихся и изменениями, происходящими в их поведении, через цифровой след. Через деятельностный подход можно определить последовательность действий, раскрывающих направление развития деятельности: «потребность - мотив - деятельность», так как именно мотив и деятельность являются внешними, объективно наблюдаемыми проявлениями, зафиксированными через цифровой след. Используем

\footnotetext{
${ }^{14}$ См. раздел IV « Эксперимент» монографии.

15 Рамки монографии не позволяют остановиться на других значимых именах, связанных с развитием «деятельностного подхода» в педагогике и психологии. Теория А. Леонтьева логично связана с теорией Л. Выготского о зонах актуального и ближайшего развития.
} 
следующую «триаду» Леонтьева: «деятельность - действие - операция». Деятельность определяется мотивом, действие определяется целью, операция определяется конкретными условиями ее протекания.

Если условия протекания операции как взаимодействия между учителем и учеником опосредованы компьютером (или любым другим гаджетом), то мотивом для деятельности может оказаться обеспечение автономии ученика, отделения от непосредственного взаимодействия с учителем или мотивом может быть самоустанавливаемая скорость обучения. Однако это не означает, что эти мотивы всегда приведут к оптимальным результатам.

На уровне действия, которое определяется целью, в условиях обучения с применением цифровых технологий это может быть стремление освоить различные образовательные платформы для собственного самосовершенствования или выполнить задание быстро и освободить время для других дел и событий.

Теория «зон ближайшего развития» позволяет разделить наблюдение за трансформацией образовательных отношений в цифровой среде на два уровня: 1) уровень «актуального развития» - в учебной деятельности с заданиями, которые школьники могут выполнить самостоятельно и 2) уровень «зоны ближайшего развития» как зоны будущего развития - в учебных действиях, которые выполняются с помощью взрослого. Важность выделения «зоны ближайшего развития» в контексте трансформации образовательных отношений в цифровой среде состоит в том, что эта «зона» для каждого ребенка имеет свои «персональные» рамки, что можно зафиксировать через цифровой след, и зависит от готовности взрослых участников образовательных отношений оказать помощь в развитии школьника. Можно утверждать, что классическое правило обучения детей на этапе актуального развития «со взрослым лучше, чем без него» работает как в традиционном, так и в цифровом формате обучения. То, что изначально доступно для ребенка под руководством взрослых, присваивается ребенком и становится его собственным достоянием, «процессы развития идут вслед за процессами обучения» [Выготский 2005].

«Большая или меньшая возможность перехода ребенка от того, что он умеет делать самостоятельно, к тому, что он умеет делать в сотрудничестве, и оказывается самым чувствительным симптомом, характеризующим динамику развития и успешность умственной деятельности ребенка» [Там же].

Одна из базовых идей Выготского о том, что процесс обучения понимается как деятельность, происходящая в сотрудничестве между взрослым и ребенком на позиции «равных», комфортно ложится на логику обучения в условиях цифровизации. Более того, эта идея как условие организации учебной деятельности заложена в гипотезу эксперимента по обучению в начальной школе: цифрровизация будет способствовать трансформачии образовательных отношений в начальной школе из традиционной массовой модели обучения в модель персонализированного обучения в том случае, если их взрослые участники смогут сотрудничать на паритетной основе с детьми и совместно вырабатывать условия проявления субъектной позиции учащихся в проектировании образовательного процесса.

Таким образом, теоретическая рамка «замкнулась» в цепочке аргументов: от теории общих систем - к социологическому «взгляду» на феномен трансформации отношений и психолого-педагогическим основаниям, обосновывающим логику изменений образовательных отношений в условиях цифровизации образования. 


\section{Вместо заключения}

Предложенные теоретические основания, объясняющие неизбежность смены образовательных ритуалов, являются не столько неколебимым фундаментом новой «образовательной нормальности», сколько поводом для дискуссий, источником для новых суждений и оригинальных экспериментов в области цифровизации образовательных отношений. Цифровизация обеспечивает новые возможности для образования, и уровень этой новизны вполне сравним с появлением более пяти веков назад книгопечатного станка и книги.

Можно с очевидностью ожидать профессионального включения в разговор о смене образовательных ритуалов со стороны нейробиологов, психолингвистов, педагогических дизайнеров и иных специалистов, которым еще не придуманы имена.

Но любой поворот идей не будет противоречить базовой для нас объясняющей теории - теории лиминальности. Переход отношений из привычного состояния в новое требует времени, так как сопровождается потерей прежних статусов (ролей) в образовательных отношениях, где нивелируется понимание иерархии в структуре этих отношений. В привычные ритуалы как взаимодействия между людьми с разными социальными и профессиональными ролями включается искусственный интеллект. В дебютных взаимодействиях (в настоящее время) это примитивная машинная включенность, позволяющая фиксировать цифровой след школьника и с его «помощью» контролировать и корректировать его учебное поведение. Процесс цифровой трансформации приведет к изменениям функционала учебных и образовательных ритуалов.

Но, вероятнее всего, ближайшее цифровое будущее образования приведет нас к «освобождению от школ», по образному выражению Ивана Иллича.

Обращаясь к текстам Ивана Иллича, мы находим актуальную идею для сегодняшних трансформаций в образовательных отношениях - идею о специальных образовательных компетентностях, которые необходимо «отделить от учебного плана» [Иллич]. Иллич пишет о трех типах таких компетентностей: «первый относится к созданию и действию образовательных изменений сетей; второй - это руководство учениками и родителями в использовании этих сетей; третий - необходимость действовать как primus inter pares, предпринимая трудные интеллектуальные исследования. Только первые два типа можно понимать как независимые ветви одной профессии: образовательные администраторы и педагогические советники. Чтобы проектировать сети и оперировать ими, как я предлагаю, не требуется большое количество людей, но это должны быть люди с наиболее глубоким пониманием образования и управления им, в перспективе совершенно отличные и даже противоположные тем, что работают сейчас в школах» [Illich].

\section{Литература}

1. Аберкомби Н. Социологический словарь / Н. Аберкомби, С. Хилл, Б. С. Тернер. М. : Экономика, $2004.620 \mathrm{C}$.

2. Абрамова М. А. Цифровизация образования в условиях цифрового неравенства / М. А. Абрамова, М. Фарника // Профессиональное образование в современном мире. 2019. Т. 9. № 4. 
3. Артемьева А. А. К вопросу о ритуале: этимология и понятие термина // Вестник Московского университета МВД России. 2010. № 7.

4. Батыгин Г. С. Структурный функционализм Толкотта Парсонса // Вестник РудН. Серия «Социология». 2003. № 4-5. С. 6-34.

5. Выготский Л. С. Проблема обучения и умственного развития в школьном возрасте // Л. С. Выготский. Избранные психологические исследования. М., 1956.

6. Выготский Л. С. Психология развития человека. М. : Смысл; Эксмо, 2005.

7. Выготский Л. С. Проблема возраста // Выготский Л. С. Собрание сочинений: в 6 т. Т. 4. М. : Педагогика, 1984.

8. Зачченко Н. А. Цифровизация образования как триггер изменений образовательных отношений // Экономика и управление. 2020. Т. 26. № 11. С. 1245-1257. Dol: https://doi.org/10.35854/19981627-2020-11-1245-1257

9. Заиченко Н. А., Набокова М. В. Цифровизация — тест на COVID // Народное образование. 2020. № 5. C. 71-80.

10. Иллич И. Освобождение от школ. 1971 [Электронный ресурс]. URL: https://ru.theanarchistlibrary. org/library/ivan-illich-osvobojdenie-ot-shkol.pdf (дата обращения: 26.08.2020).

11. Казакова Е. И. Цифровая трансформация педагогического образования // Ярославский педагогический вестник. 2020. № 1(112). С. 8-14. D0I 10.20323/1813-145X-2020-1-112-8-14.

12. Кузьминов Я. И. Эксклюзивное интервью // РБК. 17.11.2020 [Электронный ресурс]. URL: https:// tv.rbc.ru/archive/ekskluziv/5fb427392ae596d6c4e9d386 (дата обращения: 12.07.2021).

13. Леонтьев А. Н. Деятельность. Сознание. Личность. М., 1977.

14. Малиновский Б. Научная теория культуры и другие эссе [1944]. М. : 0ГИ, 2005.

15. Оборин М. С. Влияние пандемии COVID-19 на образовательный процесс // Сервис в России и за рубежом. 2020. T. 14. № 5. С. 153-163. D01 10.24411/1995-042Х-2020-10514.

16. Обучение цифровым навыкам: глобальные вызовы и передовые практики : аналитический отчет. М. : Корпоративный университет Сбербанка, 2018.

17. Парсонс Т. 0 структуре социального действия. М. : Академический проект, 2000.

18. Пригожин И. Порядок из хаоса : Новый диалог человека с природой / И. Пригожин, И. Стенгерс. М. : Прогресс, 1986.

19. Проблемы и перспективы цифровой трансформации образования в России и Китае. II Российскокитайская конференция исследователей образования «Цифровая трансформация образования и искусственный интеллект». Москва, 26-27 сентября 2019 г. / А. Ю. Уваров, С. Ван, Ц. Кан [и др.] ; отв. ред. И. В. Дворецкая ; пер. с кит. Н. С. Кучмы ; Нац. исслед. ун-т «Высшая школа экономики». М. : Изд. дом Высшей школы экономики, 2019.

20. Радаев В. Миллениалы: как меняется российское общество / В. В. Радаев ; Нац. исслед. ун-т «Высшая школа экономики». 2-е изд.-М. : Изд. дом Высшей школы экономики, 2020.

21. Рабочий доклад Департамента корпоративного обучения Московской школы управления «Сколково». «Цифровое производство: методы, экосистемы, технологии». Ноябрь 2017 г.

22. Рубинштейн С. Л. Человек и мир // Вопросы философии. 1966. № 7.

23. Талеб Н. Н. Антихрупкость. Как извлечь выгоду из хаоса. М. : КоЛибри; Азбука-Аттикус, 2014.

24. Тульчинский Г. Л. Проективный философский словарь: новые термины и понятия / под ред. Г. Л. Тульчинского, М. Н. Эпштейна. Алетейя, 2003.

25. Тэрнер В. Символ и ритуал. М. : Главная редакция восточной литературы издательства «Наука», 1983.277 c.

26. Школьный барометр. COVID-19: ситуация сучением и обучением в российских школах. Аналитический бюллетень НИУ ВШЭ обэкономических и социальных последствиях коронавируса в России и в мире / Н. В. Исаева, А. Г. Каспржак, А. А. Кобцева, М. А. Цатрян. 2020.

27. Цифровая трансформация отраслей: стартовые условия и приоритеты : докл. кXXII Апр. междунар. науч. конф. по проблемам развития экономики и общества, Москва, 13-30 апреля 2021 г. / Г. И. Абдрахманова, К. Б. Быховский, Н. Н. Веселитская, К. О. Вишневский, Л. М. Гохберг [и др.] ; 
рук. авт. кол. П. Б. Рудник ; науч. ред. Л. М. Гохберг, П. Б. Рудник, К. О. Вишневский, Т. С. Зинина ; Нац. исслед. ун-т «Высшая школа экономики». М. : Изд. дом Высшей школы экономики, 2021.

28. Штомпка П. Социология социальных изменений / пер. с англ. под ред. В. А. Ядова. М. :Аспект Пресс, 1996.

29. Фусу Л. И. Концепции лиминальности в научном дискурсе как междисциплинарная проблема // Контекст и рефлексия: философия о мире и человеке. 2017. Т. 6. № 3А. С. 240-246.

30. Gennep A V. The rites of passage / trans. by M. B. Vizedom, G. L. Caffe. London : Routledge and Kegan Paul, 1960.

31. Illich I. Deschooling society. London: Penguin, 1973.

32. Prigogine I. The philosophy of instability. Futures, 1989.

33. Turner V. Liminal to liminoid in play, flow, and ritual: An essay in comparative symbology. Rice University Studies, 1974.

34. Parsons T. Structura of Social Action. N. Y., London : McGraw Hill, 1937. P. VI.

35. Parsons T. Essays in Sociological Theory. New York : Free Press, 1949.

36. Sztompka P. The Sociology of Social Change. Oxford and Cambridge : Blackwell, 1993. 


\section{ГЛАВА 3}

\section{Цифровая трансформация школы \\ и изменения в управлении учебным процессом}

\section{1. Самообучение как основа управления образованием}

Цифровая модернизация оказывает значительное влияние на все аспекты образовательного процесса, приводит к изменениям в дидактике и установлению новых ритуалов в отношениях между его субъектами. Необходимость выработки стратегии цифровой трансформации делает особенно актуальными вопросы управления учебным процессом на разных ступенях образования и в первую очередь в общеобразовательной школе как в социальном институте, обладающем особой значимостью для развития общества.

В последующем изложении мы не будем касаться вопроса, как цифровизация влияет на изменение содержания образования, методик преподавания и форм организации обучения, а сосредоточим внимание на том, что нового могут привнести компьютерные технологии в ролевые отношения между субъектами учебного процесса.

Цифровизация, как и другие инновационные процессы, связанные с реализацией потенциала новых технологий, приводит к большей регламентации ритуалов в сфере образования, формализации процедур взаимодействия между различными участниками образовательных отношений. Гуманитарная по своей природе сфера образования приобретает новые черты и в управленческом аспекте сближается с системами технологического характера. Фундаментальные положения, обобщающие законы управления, которые действуют применительно к техническим устройствам, живым организмам и социальным структурам, были сформулированы основоположником кибернетики Н. Винером [Винер 1968, 2019]. Его работы, написанные в период, когда значимость развития вычислительной техники для социальной сферы еще не была очевидной, сохраняют свое значение и в настоящее время, когда использование цифровых технологий в образовании становится одной из наиболее актуальных тенденций.

Вместе с тем единство законов управления вовсе не отрицает необходимость учета специфики природы различных объектов. Очевидно, что система образования, в которой объектами и субъектами управления являются люди, вступающие в различные отношения между собой, не может уподобляться технической системе, в которой компоненты лишены субъектности, а все процессы предельно формализованы.

Здесь надо отметить, что полвека назад идеи использования компьютеров в образовательном процессе сразу же привлекли внимание многих 
специалистов в области управления [Берг]. При сравнении приоритетов сегодняшней цифровой трансформации с представлениями 1960-х гг. обращает на себя внимание, что в те времена преобладали методы централизованного управления всеми процессами и в том числе обучением, а в наши дни все участники образовательных отношений располагают компьютерными инструментами, поддерживающими их влияние на учебный процесс в соответствии с субъектными ролями, то есть компьютерное управление становится децентрализованным и полисубъектным.

Для сложно организованных структур, к которым относится система образования, Винер сформулировал концепцию управления, основанного на самообучении субъектов, влияющих на принятие решений. Согласно этой концепции, управление должно быть динамическим итеративным процессом, в котором все решения основываются на информации, получаемой субъектом управления по каналам обратной связи в реальном времени.

Обратная связь понимается как поток информации, характеризующий состояние объекта управления и направленный к субъекту. Субъект, по Винеру, не должен придерживаться какой-то фиксированной стратегии управления без учета последствий, к которым привели его предшествующие действия. Если цель управления не была достигнута, необходимо скорректировать свой план действий, основываясь на информации о текущем состоянии объекта управления, то есть на обратной связи. «...Обратная связь есть метод управления системой путем включения в нее результатов предшествующего выполнения ею своих задач» [Винер 2019].

Для каждого субъекта, участвующего в процессе управления, использование обратной связи является формой познания. Винер подчеркивает, что человек как биологический объект обладает значительным потенциалом развития, проводит примерно 40\% своей жизни в фазе учения и, следовательно, способен корректировать свои действия в связи с поступлением новой информации. Это представление относится ко всем участникам образовательных отношений, способным изменять поведение за счет анализа обратной связи. Поэтому процесс управления может быть определен как самообучение различных субъектов и, в идеале, системы в целом.

Концепция самообучения может стать основой системы профессионального роста педагогов на стадии цифровизации школы. А. Ю. Уваров [Уваров], сопоставляя различные сценарии цифровой трансформации, указывает на два принципиально разных пути. Консервативный сценарий сохраняет администрирование всех процессов сверху. Именно этот принцип управления Н. Винер критиковал, исходя из представлений о вероятной неадекватности управления реальному состоянию объекта: «административные должностные лица - будь то в правительстве, в университете или в акционерном обществе - должны принимать участие в двустороннем потоке связи, а не просто отдавать приказы, исходящие сверху. Иначе может оказаться, что высшие должностные лица основывают свою политику на совершенно неправильном представлении о фактах, которыми располагают их подчиненные» [Винер 2019]. В противоположность административному управлению сценарий развития реализуется на основе самообучения: «Школы преобразуются в полноценные обучающиеся организации с результативно-персонализированной организацией обучения» [Уваров]. Очевидно, что анализ современного эксперта исходит из того же противопоставления консервативного 
администрирования и самообучающейся системы, сформулированного Н. Винером в середине XX в.

Анализ целевых установок субъектов, участвующих в управлении образованием, выходит за рамки настоящей главы. В контексте обсуждаемой темы важно лишь подчеркнуть, что цифровые технологии предоставляют качественно новые возможности для сбора, анализа и интерпретации информации об объектах управления и тем самым создают условия для реализации в системе образования принципов самообучения как в педагогическом, так и в управленческом смысле этого понятия. Каждый из участников образовательных отношений выбирает из предоставляемого массива информации 16 те данные, которые необходимы для реализации его субъектной роли. Поэтому эффективное взаимодействие в управлении в полной мере реализуется лишь при условии, что каждый субъект (исходя из собственного целеполагания) строит свой контур обратной связи и использует доступные ему данные для выбора адекватных воздействий на объект управления.

\section{2. Учебный процесс как объект управления}

Ключевым положением кибернетики Винера является неразрывная связь между заранее заданной целевой установкой, на которую направлено управление, и постоянно обновляемой информацией, характеризующей текущее состояние объекта управления. В условиях цифровой трансформации и развития технологий искусственного интеллекта появляется возможность реализовать на практике представление о самообучении как о процессе, в котором управление постоянно совершенствуется за счет накопления информации о состоянии управляемого объекта. Таким образом, понятие самообучения становится ключевым и для достижения планируемых образовательных результатов, и как обоснование процедур совершенствования управленческих решений.

Кибернетика, будучи формальной дисциплиной, позволяет строить модели отношений между субъектами и объектами управления даже для сложных систем социального типа. Мы будем понимать под объектом управления учебный процесс (УП), то есть одну из составляющих образовательного процесса, реализуемого в рамках формального обучения. Применительно к практике общеобразовательной школы УП может быть определен как область образовательных отношений, непосредственно связанная с выполнением учебных действий обучающимися под руководством (прямым или опосредованным) других (взрослых) субъектов.

Согласно современным представлениям, целью управления УП является максимально полное удовлетворение потребностей обучающегося, учет его индивидуальных особенностей в контексте достижения желаемых (с точки зрения общества) образовательных результатов. Этой цели должны быть подчинены усилия всех уровней образовательной иерархии. При этом необходимо учитывать, что на состояние УП влияют различные субъекты, реализующие собственные сценарии поведения и вступающие друг с другом в сложные субъект-субъектные отношения.

${ }^{16}$ В пилотном эксперименте (см. раздел IV «Эксперимент» данной монографии), являющемся составной частью исследования, основу этого массива составляет цифровой след учебных действий, фиксируемый на образовательной платформе. 
Как и во многих других управленческих задачах, разработка и реализация стратегии управления УП осложняется недостаточностью точных сведений об объекте, его внутренних механизмах, качественных и количественных характеристиках. Классическая теория управления рекомендует рассматривать такой объект как «черный ящик», о внутренних свойствах которого можно судить, наблюдая его реакции на различные воздействия со стороны субъекта или субъектов управления. Очевидно, что подобное стимулирование и изучение реакций объекта должно предшествовать непосредственно управлению. Эта фаза исследования называется идентификацией объекта ${ }^{17}$. Методы обработки результатов наблюдения для уточнения описания объекта управления были систематизированы П. Эйкхоффом [Эйкхофф]. Развитие цифровых технологий в управлении образованием делает эти методы применимыми и для построения формальных моделей учебного процесса.

Особую сложность представляет идентификация такого объекта, который пока еще только проектируется и не существует в реальности, следовательно, не может быть изучен непосредственным наблюдением. В подобных случаях требуется создание модельного прототипа, чтобы использовать его в качестве полигона для исследования основных характеристик того объекта, которым предстоит управлять в будущем. Исследование процессов цифровой трансформации является примером такой управленческой задачи. Необходимо создать условия для активного проявления субъектного поведения различных участников образовательных отношений: как самих обучающихся, так и взрослых, участвующих в процессе обучения. В пилотном эксперименте эти условия были созданы в рамках инновационной учебной практики — информационного тренинга ${ }^{18}$.

Чтобы оценить предполагаемые эффекты цифровизации, нужны экспериментальные данные, наблюдения за учебными и управленческими действиями, осуществляемыми в цифровой среде. Сегодня образовательная среда пока не является цифровой, и если проводить идентификацию УП в существующих условиях, то мы рискуем получить неадекватное представление о действиях субъектов и о факторах, влияющих на результативность управления. Поэтому для получения достоверного прогноза на перспективу должна быть предложена модель, которая в существенных проявлениях соответствует представлениям об образовательных отношениях в цифровой среде и может быть использована для эксперимента, в ходе которого будет решаться задача идентификации объекта управления - цифрового УП.

Для решения задачи идентификации следует изучать изменения характеристик объекта как реакции на различные воздействия. В качестве основных процессов, подлежащих моделированию, целесообразно выделить следующие:

- учебные действия обучающихся;

- управление индивидуальными и групповыми учебными траекториями обучающихся со стороны учителя;

- мониторинг результатов учебных действий;

\footnotetext{
17 Идентификация - определение характеристик объекта и выявление приложенных к нему воздействий с помощью наблюдения за его входами и выходами и статистической обработки полученных данных. См: Экономико-математический словарь [Электронный реcypc]. URL: https://economic_mathematics.academic.ru/1710/Идентификация_объекта (дата обращения: 12.07.2021).

18 См. раздел IV «Эксперимент».
} 
- внутришкольная оценка качества;

- оперативное управление со стороны администрации образовательной организации;

- взаимодействие педагогов и родителей вокруг образовательных результатов конкретных обучающихся ${ }^{19}$.

\section{3. Субъекты управления и отношения между ними}

В современной педагогике, как и в кибернетике, одним из ключевых понятий является субъект ${ }^{20}$. В образовательных отношениях прошлого роли преподавателя и ученика сводились к позициям управляющего и управляемого, фактически лишая обучаемого субъектности, то есть влияния на выбор образовательного маршрута. Это не означает, что в этой модели педагог управлял, игнорируя реакцию ученика. Он периодически анализировал сигналы обратной связи, чтобы иметь представление, к каким результатам приводит его управление. Но главная характеристика субъекта - это право на управляющее воздействие в соответствии с принятым целеполаганием, и это право целиком оставалось за преподавателем. Подобные системы, в которых субъектностью исполнителя пренебрегают, характеризуются жесткой дисциплиной. Они типичны для индустриального производства конвейерного типа или военной организации, но не подходят для современной системы образования, в которой одной из главных ценностей является развитие личности обучаемого. В то же время нельзя забывать о том, что собственно обучение является лишь одним из уровней иерархической системы управления образованием. Эта система работает на определенные цели и не может предоставить полную свободу не только ученикам, но и педагогам, непосредственно вовлеченным в учебный процесс.

Целеполагание задается сверху и ограничивает свободу принятия решений и самостоятельность участников образовательных отношений. Тут нет неразрешимого противоречия между идеей субъектности и идеей подчиненности. Человек - настолько сложная система, что может одновременно выступать и в роли субъекта, и в роли объекта управления. Например, в ходе аттестационных процедур субъектность ученика сводится к минимуму. В других образовательных ситуациях отношение между субъектностью и подчиненностью определяется ритуалами взаимодействия педагогов и обучаемых. При репродуктивном обучении акцентировалась объектная роль ученика, а сегодня, когда педагогика в образовательном процессе отводит более значимое место активному учению, планированию собственных действий, самоконтролю, в поведении обучающегося начинает преобладать субъектность.

Если мы поднимемся вверх по образовательной иерархии, то увидим, что по отношению к задачам управления образовательным процессом в масштабах школы учитель и сам в значительной степени теряет свою субъектность. В жестко регламентированной системе администрирования он вынужден

19 Все перечисленные процессы анализируются на основе цифрового следа, фиксируемого в рамках пилотного эксперимента (см. раздел IV «Эксперимент»).

20 Здесь и далее применительно к субъектам управления термин «субъектность» используется как равнозначный термину «агентивность», являющемуся калькой английского аналога (см. главу 4). 
подчиняться спускаемым сверху установкам и практическим рецептам, то есть превращается в объект управления по отношению к институциям, определяющим образовательную политику. Поэтому любая управленческая реформа, а тем более столь масштабная, как цифровая трансформация, должна переопределять границы субъектности всех уровней иерархии, распределение полномочий и ответственности между ними.

Начнем рассмотрение многоуровневой системы управления снизу, то есть с позиции ученика относительно других субъектов, участвующих в образовательных отношениях. Как уже было отмечено, в деятельностной педагогике ученик сочетает в себе две роли: и объекта, и субъекта управления. Отсутствие баланса между этими ролями может привести к нежелательным последствиям.

Если субъектность ученика игнорируется, то он становится пассивным участником процесса обучения, страдают мотивация и способность к сознательному учению. Формальные результаты такого обучения могут быть достаточно высоки, но пассивность обучающегося не способствует личностному развитию, реализации интеллектуального и творческого потенциала. Педагог, управляющий таким УП, в котором его ученики не являются самостоятельными субъектами, рассматривает их ответы на контрольные вопросы не столько как свидетельство достижения ими образовательных результатов, сколько как сигналы обратной связи, подтверждающие, что он как преподаватель выполнил свои обязанности.

Напротив, если субъектность ученика преувеличивается, то он может получить чрезмерную свободу в определении целей УП и, в частности, своего собственного целеполагания. Субъектность ученика может в такой ситуации вступить в противоречие с субъектностью других участников образовательного процесса и прежде всего учителя. Это, в свою очередь, приводит к конфликтам между семьей, стоящей на стороне ребенка, и системой формального образования. Механизмы разрешения подобных коллизий, удовлетворяющие все стороны, пока должным образом не выстроены, что в сложноорганизованном обществе чревато кризисом школы как важнейшего социального института.

Оптимальный уровень субъектности ученика в его взаимоотношениях со взрослыми участниками образовательного процесса может быть рассмотрен в контексте учения о зонах развития и их границах [Выготский]. Очевидно, что сознательное образовательное поведение не может быть реализовано без учета возрастных, личностных и когнитивных возможностей обучающегося. Положение Выготского о том, что ребенку для перехода в зону ближайшего развития требуется помощь взрослого, здесь следует трактовать не только в познавательном, но и в управленческом аспекте.

Если самостоятельное учение находится в зоне актуального развития ребенка, роль взрослых может сводиться к обеспечению условий для самостоятельной работы обучающегося. Напротив, если это требование не выполняется, то предоставлять обучающемуся право принимать ответственные решения в процессе обучения - преждевременно. Оценить, в какой степени самостоятельные действия посильны конкретному ученику, - задача, которая становится ключевой в управлении учебным процессом. До тех пор, пока нет надежных методов оценивания реальных субъектных возможностей ребенка, практическая реализация персонализированной модели будет сталкиваться с серьезными трудностями. 


\section{4. Смена образовательных ритуалов в цифровой среде}

Цифровая трансформация может рассматриваться как изменение в отношениях между субъектами образовательного процесса. В этом контексте особую значимость приобретает представление об алгоритмическом характере действий и взаимодействий в цифровом формате, так как детерминированность отношений упрощает построение адекватной модели. Кроме того, в процессе цифровой трансформации в некоторых ситуациях могут меняться не только сами алгоритмы, но и их исполнители, что также соответствует представлению о смене образовательных ритуалов в процессе цифровизации ${ }^{21}$.

Рассмотрим некоторые взаимодействия между субъектами на примере учебной практики, переносимой из привычной образовательной среды в цифровую.

В традиционном обучении отношения между преподавателем и учеником строились по стандартной схеме (рис. 3): преподаватель направляет ход учебного процесса, обучающийся откликается на его воздействия. В терминах теории управления: ученик - объект, а преподаватель - субъект. Изложение материала - прямая связь, выполнение контрольных заданий обратная. Эта простая схема отношений подразумевает определенность ритуала и заданность ролей. Ученик подчинен преподавателю, который в идеальной схеме - полностью контролирует УП и направляет его в сторону достижения планируемых показателей. Он же оценивает результаты обучения на основании проверки контрольных заданий. Отметим еще раз, что для многих педагогов контрольное задание психологически воспринимается как способ оценки собственной работы, а не достижений обучающегося. Если преподаватель удовлетворен оценкой, которую получил ученик, цикл управления можно считать завершенным.

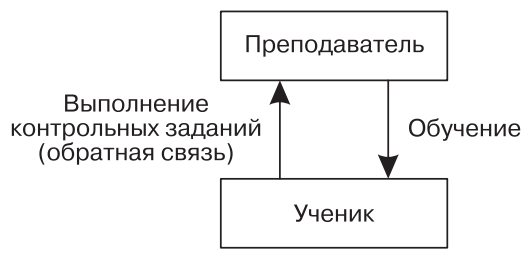

Puc. 3. Субъект-объектная модель отношений

Во многих случаях эта традиционная педагогическая схема продолжает успешно работать и сейчас, но ее ограничения становятся особенно заметны, когда обсуждается возможность перехода к персонализированной модели обучения. Если представить, что в модели, изображенной на рис. 3, преподаватель взаимодействует не с одним учеником, а с учебным коллективом, то становится ясно, что каждый из контуров управления действует тем медленнее, чем больше учеников в классе. Это замедление связано, конечно, не с изложением учебного материала, а с контролем результатов, на который затрачивается очень много времени. Фактически контур обратной связи размыкается после того, как ученик выполнил контрольное задание. Независимо от того, какова оценка, она приходит с существенной задержкой, когда обучающийся уже утратил ментальную связь с выполненным заданием.

\footnotetext{
${ }^{21}$ См. главу 2.
} 
Кроме того, в психологическом аспекте у этой схемы есть существенный недостаток. С точки зрения ученика, преподаватель, проверяющий выполненную работу, оказывается оппонентом, соперником, над которым нужно «одержать победу». Иногда ради этой цели, чтобы ввести преподавателя в заблуждение, используются не самые похвальные методы. Но даже когда все сделано честно, остается ощущение того, что ученик и преподаватель находятся «по разные стороны баррикад». Роль контролера — не самая выгодная для учителя, и для повышения эффективности обучения желательно найти способ перестроить отношения с учеником таким образом, чтобы они стали партнерскими и более доверительными.

Современная педагогика считает, что следует отказаться от идеи, что ученик является лишь пассивным объектом управления, отношения должны стать субъект-субъектными. Это, в частности, означает, что ученик хотя бы в некоторой степени должен научиться воспринимать обучение как собственную задачу, чтобы в его отношении к учебному процессу появились элементы самоуправления и самоконтроля. На рис. 4 модель дополнена (по сравнению с рис. 3) контуром самопроверки, выполняемой обучающимся.

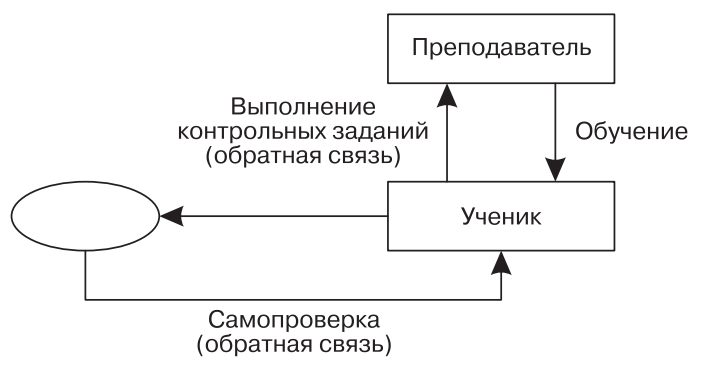

Рис. 4. Модель с самопроверкой

Алгоритм работы модели с самопроверкой, изображенной на рис. 4, сложнее, но эффективнее. Ученик проверяет свою работу, прежде чем передать ее на проверку преподавателю. Если ему самому удается обнаружить хотя бы часть ошибок и исправить их, то и итоговая оценка преподавателя окажется выше, чем в предыдущей схеме.

Добиться ответственного отношения к работе непросто даже тогда, когда ученик представляет собой уже сформировавшуюся личность, осознающую собственную мотивацию к учению. Тем более сложно достижение полноценной субъектности происходит у детей младшего возраста, когда они только приступают к регулярным занятиям. Их сложно приучить к самопроверке, и без внешнего контроля они не смогут добиваться требуемых результатов. Поэтому в схеме, приведенной на рис. 4, сочетаются два вида обратной связи: самопроверка и проверка преподавателя.

Критерием готовности ученика к субъектной роли может служить его способность к самообучению, по Винеру. Как уже было отмечено, самообучение в кибернетическом смысле - это циклический процесс, состоящий из нескольких фаз: познавательное действие, оценка результата этого действия, коррекция поведения с целью улучшения результатов. Если проанализировать этот цикл, то окажется, что в качестве обратной связи должна использоваться оценка совершенного учеником действия. Эту оценку, в принципе, может осуществлять и сам ученик, но такое поведение возможно только 
в пределах зоны актуального развития. А вот для перехода в зону ближайшего развития, по Выготскому, требуется взаимодействие ученика с каким-то другим участником УП, который, в частности, может выступать в качестве источника информации (обратной связи) для принятия учеником решения о дальнейших действиях.

\section{5. Цифровая среда: самообучение ученика}

В современной образовательной среде в роли такого инструмента обратной связи все чаще выступает компьютер. Появление цифровых инструментов, работающих в контуре управления, может существенно повлиять на субъектные отношения, перераспределить функции и ответственность. Представим себе, что у педагога есть возможность передоверить проверку контрольных заданий компьютерной программе, которая проанализирует ответы, выявит ошибки и сообщит результат ученику. У того появится возможность сразу же самостоятельно проделать «работу над ошибками» и представить исправленный вариант для повторной проверки. Эта процедура может продолжаться и несколько раз - до тех пор, пока не будет достигнут желаемый результат. Конечно, таким образом можно проверить далеко не всякое задание. Объективно оценить любое учебное действие - это задача, которую, возможно, удастся доверить искусственному интеллекту, а это произойдет еще не скоро. Но все же немалую долю учебных заданий можно формулировать так, чтобы проверка осуществлялась по предварительно заданному однозначному алгоритму, с выполнением которого программа может справиться не хуже, чем человек. Если составлению заданий с формализуемыми ответами уделить должное внимание и перенести соответствующие учебные активности на цифровые платформы, то уже сегодня компьютер сможет оказать существенную помощь в освобождении учителя от рутинных функций контроля.

Схема новой модели (рис. 5) внешне похожа на рис. 3, но роли распределены совсем по-другому. В контуре управления теперь активная роль субъекта отводится ученику, а контрольная - компьютеру. Прямая связь - выполнение задания, обратная - автоматическая проверка. Технологическое усовершенствование привело к изменению ролевых отношений. В компьютеризированной модели по сравнению с исходной создан потенциал для того, чтобы пассивное восприятие учебного материала превратилось в активное учение, то есть для самообучения одного из субъектов образовательного процесса - самого обучающегося.

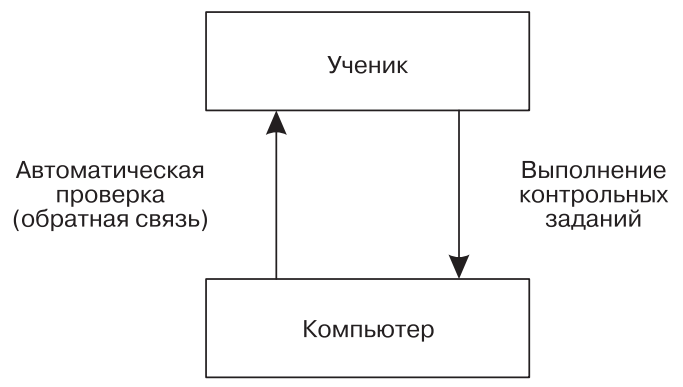

Puc. 5. Модель активной цифровой практики 
При использовании компьютера обратная связь работает оперативно, ученик узнает результат проверки, пока он еще не успел отвлечься от сути выполненного задания (в отличие от ситуации проверки заданий учителем, при которой результат собственной деятельности ученик узнает не сразу, да и ошибки в этом случае приходят к нему уже исправленными). С точки зрения личностного развития это благоприятная ситуация: в момент получения обратной связи ученик еще находится «в рабочем режиме» и готов немедленно и самостоятельно реагировать на сообщение о том, что им были допущены ошибки. И в этом ролевом распределении, как показано на рис. 6 , результаты могут стать выше по сравнению с моделью, представленной на рис. 5, если добавить локальную обратную связь, то есть контур самопроверки.

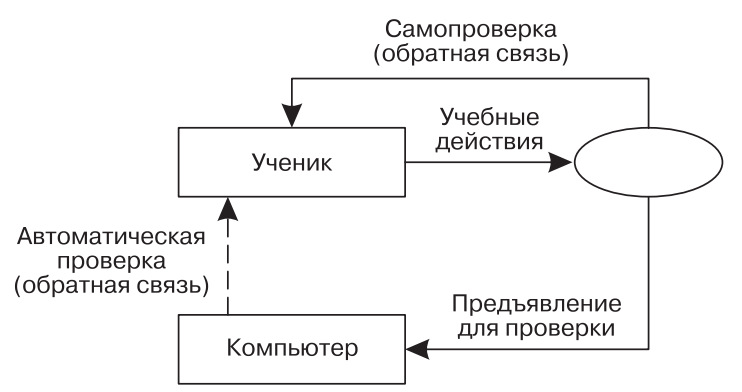

Рис. 6. Модель цифровой практики с самопроверкой ученика

Отметим попутно, что переход от взаимодействия «учитель - ученик» к взаимодействию «ученик - компьютер» несет с собой и смену психологической установки в личностных отношениях. Теперь в роли оппонента выступает не «живой» преподаватель, а «железный» компьютер. Негатив в отношениях, если он есть, не переносится на личность «контролера», а замыкается во взаимодействии между учеником и компьютерной программой. Как правило, в детском восприятии компьютер рассматривается как источник достоверной информации. Обижаться на «железку» за снижение оценки не приходится. Но даже если можно подозревать некорректность в компьютерной программе, то негативный результат проверки во всяком случае психологически не расценивается как необъективное и недоброжелательное отношение «лично ко мне». Поэтому сигнал обратной связи, полученный от программы в ответ на выполненные учебные действия, помогает сформировать у ученика более объективное отношение к своей работе. Возникают условия для адекватной самооценки достигнутых результатов, а на основе правильной самооценки развивается и сознательное отношение к обучению в целом.

С другой стороны, когда контрольные функции выполняет компьютер, у учителя уже нет оснований оставаться оппонентом по отношению к своему ученику. Его новая субъектность ближе к роли наставника, который не оценивает результат, а способствует его достижению.

\section{6. Цифровая среда: самообучение учителя}

Перейдем теперь на следующий уровень образовательной иерархии и проанализируем, как могут измениться в цифровой среде роль учителя и его взаимодействие с обучающимися. В изображенных на рис. 5 и 6 контурах 
вроде бы нет места для преподавателя. Передача даже части функций от педагога компьютеру вызывает естественный протест у всех, кто понимает, насколько сложно может складываться процесс обучения у школьников. И как важна в достижении зоны ближайшего развития роль взрослых, особенно в младшем возрасте, когда у детей еще не сформировались умение учиться и необходимая самостоятельность. Нет сомнений, что для достижения планируемых образовательных результатов детям требуется помощь учителя. Но вот только помощь не должна сводиться именно к контролю. И если цифровизация частично может избавить учителя от контрольных функций (оставив за ним проверку творческих заданий открытого типа), отношения между ним и учеником должны развернуться в сторону сотрудничества.

Таким образом, возникает модель, в которой роль преподавателя остается лидирующей, как и в схеме на рис. 4, но взаимоотношения с учеником строятся на других основаниях. Несмотря на главенствующее положение педагога (супервизора) ученик обладает субъектностью, а его действия контролируются им самим, а также через обратную связь, замыкаемую на компьютер (рис. 7).

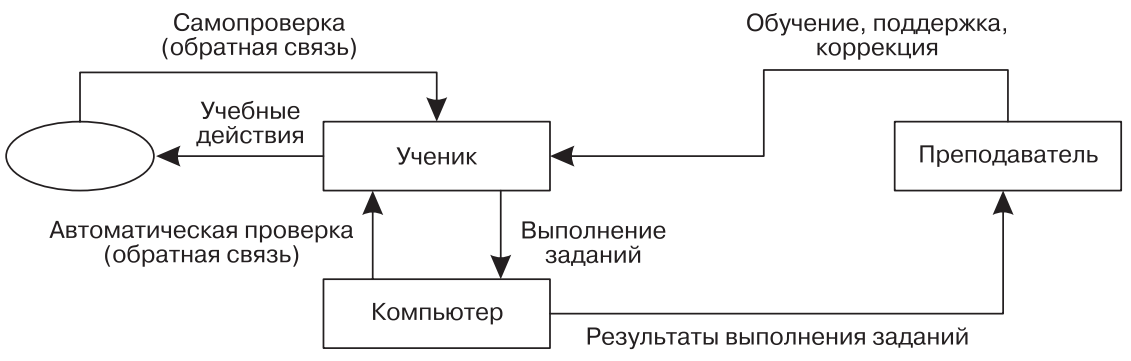

Рuс. 7. Модель супервизорного управления

В целом организация обучения остается традиционной, однако в новом контуре управления учитель становится скорее наставником, а не оппонентом ученика. Его роль можно сравнить с ролью тренера, поддерживающего своего воспитанника, помогающего советами, ободряющего в трудные минуты. В личностном плане достижение образовательного результата становится победой ученика. Здесь возникает вопрос: над кем? Ответ: над компьютером, который в этот момент представляет собой соперника, которого нужно победить своими правильными действиями.

Так в цифровой модели возникает возможность для установления более продуктивных отношений между педагогом и обучающимся. Ребенок с помощью взрослого превращается в субъект управления собственным учением, компьютер обеспечивает его обратной связью, необходимой для объективной самооценки. А учитель становится супервизором, который ориентирует УП в необходимом направлении с учетом реальных образовательных результатов.

Когда ученик имеет возможность самостоятельно наблюдать за результатами собственной активности, видеть достигаемый в ходе собственных действий прогресс, в контуре управления УП возникает положительная обратная связь, способствующая закреплению позитивных изменений и их динамике. Внешняя оценка влияет на способность ученика к объективной самооценке, повышает его мотивацию к ежедневной учебной деятельности, 
укрепляет уверенность в себе, побуждает к дальнейшему развитию. Самообучение ученика становится важной составляющей управления УП. В таких обстоятельствах у учителя нет необходимости постоянно вмешиваться в ход обучения и брать «рычаги управления» на себя. Наблюдая за действиями ученика и постепенно повышая учебную нагрузку, он должен следить за тем, чтобы уровень этих заданий соотносился с границами зон развития и не вышел за пределы возможностей ребенка.

Если же компьютер фиксирует негативные тенденции в работе ученика, которые не удается преодолеть за счет собственных усилий обучающегося, учитель должен вовремя вмешаться, чтобы снять стрессовую ситуацию, помочь преодолеть трудности, обрести уверенность. Очень часто для этого достаточно спокойной доверительной беседы, но эффективная поддержка может основываться только на точном понимании природы трудностей, испытываемых учеником. Здесь также важна роль компьютера, который фиксирует все учебные действия и сохраняет их для анализа - создает своего рода «цифровой след» ученика. Этот след учебных действий является важнейшим источником обратной связи для учителя, который может ознакомиться с историей выполнения заданий, выявить пробелы в подготовке учащегося, определить дефициты умений, приводящие к неудовлетворительному результату, и вместе с учеником найти правильный путь к исправлению ситуации.

Таким образом, в процессе обучения начинают совместно работать два контура управления (рис. 8). На нижнем уровне сам ученик принимает решение о том, как он должен строить свое поведение в зависимости от результатов выполнения учебных заданий (например, повторно выполнить те же действия, чтобы улучшить свои показатели). А на более высоком - учитель, обладая подробной и объективной информацией, может вносить необходимые изменения в УП с учетом особенностей конкретного ученика, подбирать проверочные и контрольные задания, чтобы компенсировать выявленные дефициты и развить имеющиеся компетенции.

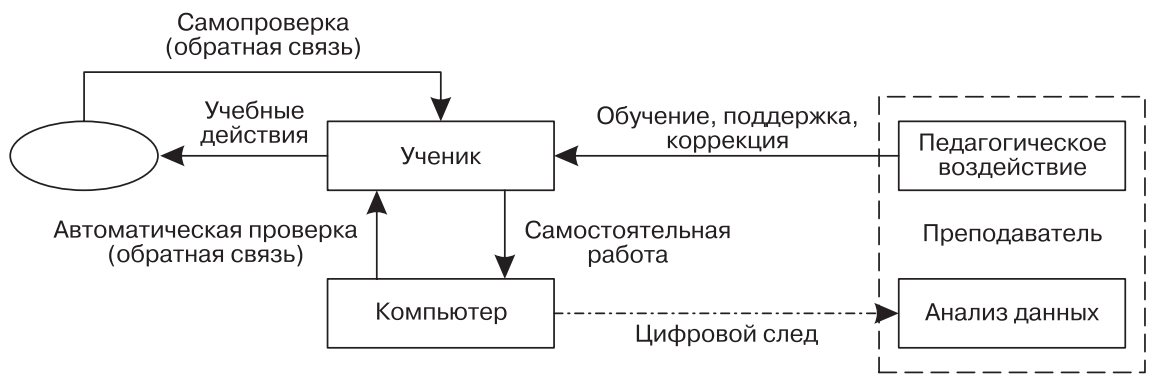

Puc. 8. Модель супервизорного управления с использованием цифрового следа

В сфере ответственности учителя остаются анализ собранных в процессе учебных действий данных об индивидуальных особенностях ученика, принятие решения о выборе дальнейшей учебной траектории и непосредственное взаимодействие с учеником. Если на цифровой платформе собираются сведения о многих учениках, занимающихся тренингом, то по мере накопления данных может сформироваться статистически репрезентативное представление о том, как должны учитываться те или иные показатели, измеряемые в ходе обучения. 
Накопление «больших данных» позволяет создать экспертную систему, которая возьмет на себя аналитическую работу и сможет предложить педагогам рекомендуемые для данного ученика учебные программы. Использование искусственного интеллекта не просто освободит учителя от необходимости самому анализировать цифровой след, но и позволит учесть многие дополнительные факторы, которые могут повлиять на принятие решений. Но экспертная система, работающая по заданным алгоритмам, ни при каких обстоятельствах не должна подменять педагога как субъекта управления. Ее роль - вспомогательная, советующая, а окончательное решение и взаимодействие с учеником остаются за учителем (рис. 9).

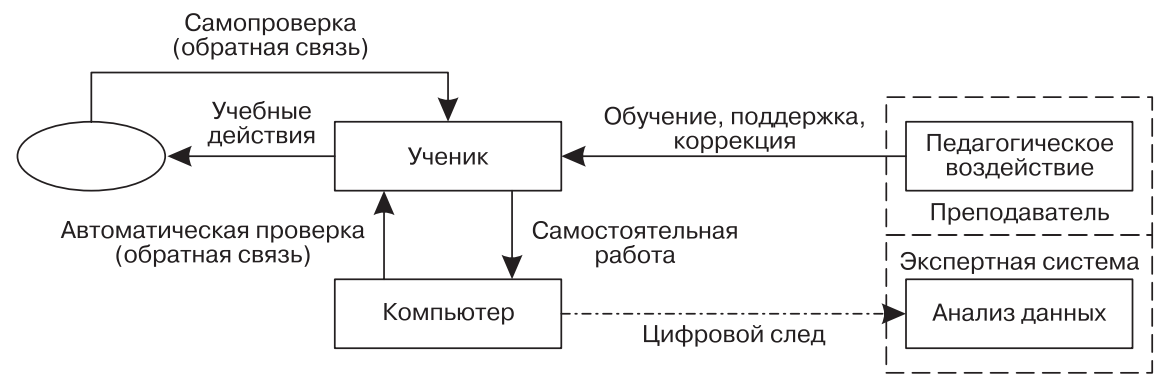

Pис. 9. Модель с экспертной системой

Когда педагог имеет оперативный доступ к цифровому следу, у него появляется возможность оперативно корректировать ход УП, изменять индивидуальные траектории с учетом реальной ситуации. На цифровой платформе (ЦП) организуется регулярный мониторинг текущих результатов, который становится информационной основой формирующего оценивания. Если учитель в достаточной степени мотивирован, чтобы анализировать данные, накапливаемые в ходе учебных действий, то фактически ЦП становится инструментом самообучения не только ученика, но и учителя (в кибернетическом смысле этого термина). В управление с обратной связью полноценно включаются обе субъектные роли, и УП приобретает новое качество.

Развивая этот подход, можно обеспечить доступ к цифровому следу не только учителю, но и другим взрослым участникам образовательного процесса: членам педагогического коллектива, а также родителям ученика и, при необходимости, психологам. Все они, имея объективные данные об учебных действиях, могут внести свой вклад в процесс формирующего оценивания и повлиять на результативность и эффективность обучения.

\section{7. Иерархия алгоритмов управления в цифровой среде}

Мы рассмотрели на простом примере, как в цифровой модели могут изменяться отношения, непосредственно связанные с учебными действиями. Появление компьютера смещает акценты в отношениях «ученик - учитель». Это по-прежнему контур управления с обратной связью, но роли распределены по-новому. Повышение субъектности ученика не означает снижение значимости фигуры учителя, находящегося в непосредственном контакте с обучаемым. Меняются образовательные ритуалы, педагог избавляется от рутинных функций контроля, но по-прежнему остается важнейшим участни- 
ком образовательных отношений. Именно от него зависит, по каким образовательным маршрутам будет двигаться каждый ученик, так как важнейшей функцией учителя становится именно корректировка индивидуальных и групповых траекторий (рис. 10).

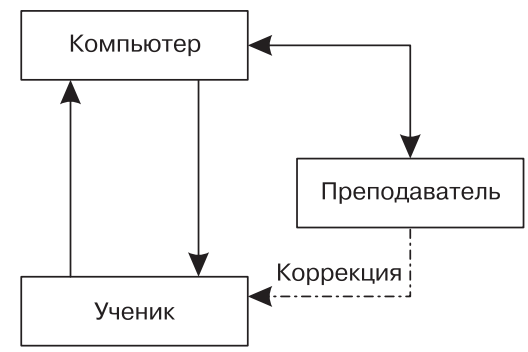

Puc. 10. Коррекция действий ученика

Рассмотрим теперь другие образовательные отношения, связанные с управлением УП. Учитель очевидно находится лишь на нижнем уровне административной иерархии, его действия контролируются и корректируются на уровне администрации школы (рис. 11).

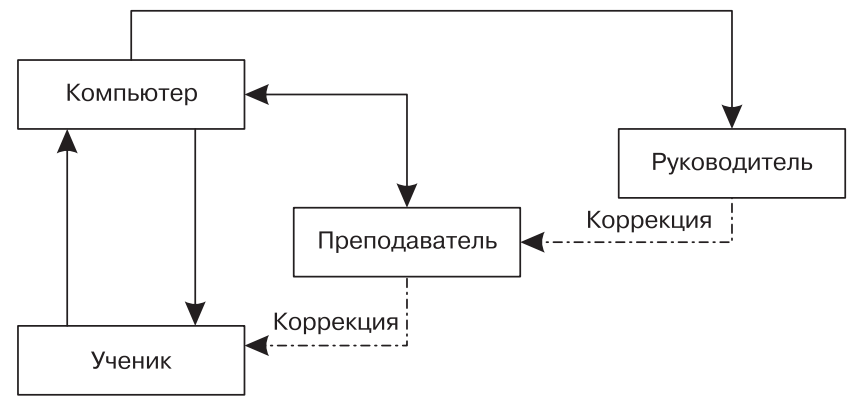

Puc. 11. Коррекция действий ученика и учителя

Отношения между преподавателем и его руководителем (школьным координатором) не связаны напрямую с учебными действиями учеников. Они основываются на оценке администратором результативности и эффективности обучения. И в этом аспекте оценивания с появлением компьютера возникают новые отношения. Здесь важно подчеркнуть, что в цифровом следе фиксируются не только учебные действия учеников, но и события, связанные с поведением учителя. Например, школьный координатор видит, как регулярно проводились занятия, насколько равномерно были загружены члены учебного коллектива, оперативно ли реагировал учитель в ситуациях, когда требовалась коррекция действий того или иного ученика. Компьютер предоставляет руководителю объективную, основанную на фиксации учебных действий информацию мониторинга УП. В этом отношении педагог перестает быть единственным источником информации, на основании которой принимает решения его руководитель. Фактически учитель исключается из канала обратной связи, а компьютер становится инструментом независимой оценки действий обучающихся.

Таким образом, на основании результатов мониторинга, фиксируемых в виде цифрового следа, руководитель может оценить, в какой степени 
учитель был вовлечен в учебный процесс, прибегал ли он к формирующему оцениванию, влиял ли должным образом на работу учеников. Это означает, что на ЦП моделируются отношения в иерархической системе управления учебным процессом. Администратор, корректируя организацию учебного процесса, выступает в роли «учителя для учителя», то есть в свою очередь включается в общий процесс самообучения системы.

Двигаясь аналогичным образом от управления на уровне отдельной образовательной организации к управлению группой школ, то есть кластером, мы переходим на новый уровень, где компьютер, собирая статистические данные, может включить в процесс управления администратора кластера (рис. 12).

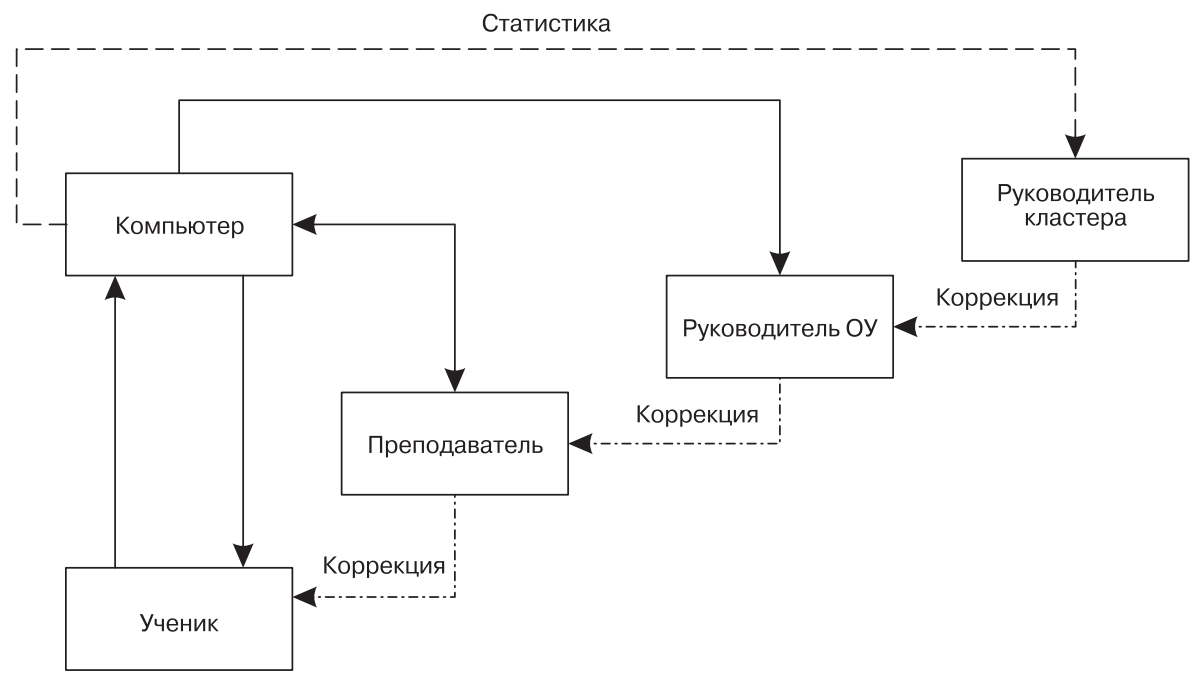

Puc. 12. Коррекция действий на уровне кластера

На этом уровне иерархии объективные данные, собираемые и обрабатываемые на ЦП, могут быть положены в основу сравнительного анализа эффективности работы различных образовательных учреждений. Сопоставляя динамику результатов с накапливаемыми на ЦП большими данными, руководитель кластера имеет возможность корректировать работу школ в организационном и методическом планах.

\section{8. Влияние родителей учеников на управление УП}

Еще один тип субъектов образовательного процесса - родители школьников. Сегодняшняя практика взаимодействия семьи и школы не может быть сведена к заранее определенным ритуалам, слишком многое зависит от конкретной образовательной ситуации. Но перспектива цифровой трансформации школы заставляет уделить особое внимание реализации субъектной позиции родителей. Новые возможности могутбыть связаны с информационной прозрачностью цифровой образовательной среды, в которой родители получают доступ к цифровому следу своих детей и могут строить свои отношения с педагогами на основе объективных данных об учебных действиях (рис. 13). 


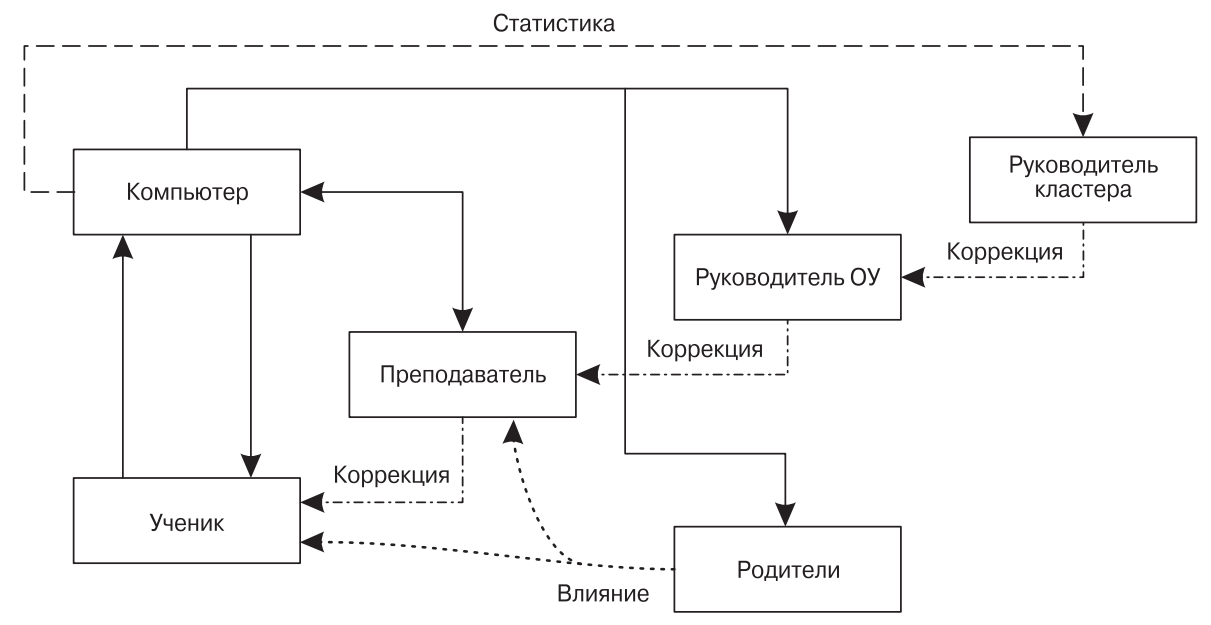

Puc. 13. Влияние родителей на управление УП

Родители не имеют доступа к механизмам непосредственной коррекции действий других субъектов, но могут оказывать свое влияние на принимаемые решения. Далеко не каждый родитель согласен выступить в роли стейкхолдера, то есть самостоятельного субъекта, включающегося в управление УП. Чаще родители выражают свое отношение через коммуникации с другими участниками образовательных отношений. Но наиболее активные родители демонстрируют готовность занять более агентивную позицию, собирать и анализировать данные обратной связи и транслировать свои предложения педагогам и администраторам. Важно, чтобы этот диалог был компетентным и конструктивным. Сегодня в практике школы такой уровень отношений встречается нечасто. Во многом это связано с тем, что обсуждение достижений и проблем ребенка ведется на эмоциональном уровне, а не на основе самообучения - вдумчивого анализа обратной связи, то есть текущих результатов. Модель, в которой учителю и родителям доступны данные цифрового следа, может изменить ситуацию в лучшую сторону. Родители станут лучше понимать учебные и личностные проблемы своего ребенка и смогут помочь учителю в выборе наиболее подходящей траектории.

\section{Выводы}

1. Цифровизация может рассматриваться как самостоятельная фаза развития системы образования, характеризующаяся качественно новым уровнем информационного обеспечения системы управления за счет цифрового следа как источника обратной связи.

2. На этапе цифровой трансформации все участники образовательных отношений получают доступ к сведениям, которые позволяют гибко менять свою стратегию управления УП в соответствии с собственным представлением о целеполагании.

3. Для управления цифровым УП требуется построение модели, основанной на фиксации учебных действий. В этой модели информационная основа отношений привязана к индивидуальной траектории ученика, а вся иерархия управления направлена на повышение результативности обучения. 
4. Уровень информационного обеспечения, достигаемый в ходе цифровизации, позволяет всем субъектам, участвующим в управлении УП, строить свое поведение согласно концепции самообучения.

5. Включение цифровых технологий в контур управления приводит к изменению ролевых функций различных субъектов, перераспределению ответственности между ними и смене образовательных ритуалов.

6. Сопоставляя схемы, приведенные на рис. 10-13, можно отметить, как на одной и той же информационной основе - данных, собираемых на ЦП в процессе учебных действий, постепенно выстраивается иерархия управленческих механизмов с обратными связями, соответствующими различным отношениям между субъектами образовательного процесса.

\section{Литература}

1. Берг А. И. Состояние и перспективы развития программированного обучения / А. И. Берг. М. : Знание, 1966. 26 с.

2. Винер Н. Кибернетика, или Управление и связь в животном и машине. 2-е изд. М. : Советское радио, 1968 [Электронный ресурс]. URL: http://filosof.historic.ru/books/item/f00/s00/z0000889/ st000.shtml (дата обращения: 12.07.2021).

3. Винер Н. Кибернетика и общество. ACT, 2019 [Электронный ресурc]. URL: https://www.gumer.info/ bibliotek_Buks/Science/viner/01.php (дата обращения: 12.07.2021).

4. Выготский Л. С. Мышление и речь. Изд. 5, испр. М. : Лабиринт, 1999. 352 с.

5. Уваров А. Ю. Цифровая трансформация и сценарии развития общего образования / Национальный исследовательский университет «Высшая школа экономики», Институт образования. М. : НИУ ВШЭ, 2020. 108 с. (Современная аналитика образования. № 16(46)).

6. Эйкхофф П. Основы идентификации систем управления. М. : Мир, 1975. 


\section{ГЛАВА 4}

\section{Цифра и агентивность учителя в международных исследованиях}

В данной главе представлен сравнительный анализ работ зарубежных исследователей по проблеме развития цифровых компетенций учителей начальной школы, цифровой грамотности этих учителей и приобретения этих компетенций через цифровое обучение. Следует заметить, что понятия «цифровые компетенции» и «цифровая грамотность» широко используются в описаниях международных исследований и часто взаимно заменяют друг друга. Объем данного аналитического сравнительного анализа ограничен статьями, цитируемыми в базах данных Scopus и Web of Science (WoS) за последние пять лет, иллюстрирующими разнообразные проблемы, связанные с приобретением учителями цифровых навыков и развитием их цифровых компетенций в педагогической практике.

При отборе исследовательских работ уделено особое внимание такому явлению, как непосредственное «агентивное» участие самих учителей в приобретении и овладении цифровыми навыками. Настоящий анализ посвящен выявлению «агентивных ориентаций» [Emirbayer] и роли этих ориентаций при формировании учителем своей цифровой грамотности. Отобранные исследования непосредственно к теории агентивности не относятся, но имеют прямое отношение к понятию «цифровой опыт». Феномен агентивного участия учителей тесно связан в ранее проведенных исследованиях с новаторским поведением учителей [Toom 2015; Eteläpelto 2014] и, напротив, с их сопротивлением нововведениям [Vähäsantanen]. Теоретическая концепция «агентивность» может представлять особый интерес в связи с приобретением учителями навыков цифровой грамотности, поскольку ассоциируется со способностью учителя действовать эффективно и стратегично в любой профессиональной ситуации. Понятию агентивности посвящается следующий параграф этой главы.

Цифровая грамотность в современных международных исследованиях часто имеет тесную связь с тем, как учителя относятся к информационнокоммуникационным технологиям (ИКТ), а также с их склонностью применять новаторские или консервативные стратегии преподавания в классе [Toom 2017; Heikonen]. Растущее число количественных исследований о цифровой компетентности учителей может свидетельствовать о том, что учителя не всегда положительно относятся к использованию ИКТ в классе [Wu; Admiral], особенно на начальной ступени образования, которая представляет наибольший интерес в рамках данной монографии.

Стратегия выборки исследований, предлагаемая в этом контексте, основывается на предварительном исследовательском вопросе «Какова роль 
агентивности учителя в получении им цифровых компетенций (навыков) в целях преподавания?». И мы делаем попытку найти ответ на этот вопрос через призму текущих международных исследований, посвященных цифровой грамотности учителей и приобретению ими цифрового опыта. Следует акцентировать внимание читателя на том, что все англоязычные статьи, включенные в выборку, эксплуатируют такие контекстные понятия, как: 1) цифровая грамотность учителей (digital literacy of teachers); 2) цифровые навыки (digital skills); 3) ИКТ-обучение учителей (teachers ICT development); 4) цифровая компетентность учителей (teachers digital competence); 5) начальное образование (primary education), - и не включают понятие «агентивность» (agency) ${ }^{22}$.

Итак, основная цель данной работы заключалась в анализе того, включает ли феномен цифровой грамотности учителей, исследованный на международном уровне за последние пять лет, концепцию агентивности при поиске объяснений мотивации учителей к овладению цифровыми навыками; их склонности к применению цифровых стратегий или их сопротивления использованию цифровых устройств в педагогической практике. Поскольку автор склонен придерживаться позиции, что агентивность проявляется во всех практиках учителей - не только нерутинных [Brock], но и вполне рутинных, обеспечивающих определенный профессиональный модус вивенди [Archer 2007, 2010], целью было выяснить, освещают ли исследования цифровой грамотности учителей (в частности, учителей начальной ступени обучения) данный опыт с точки зрения агентивности учителя; является ли концепция агентивности значимой и прослеживается ли ее включение в исследование феноменов, которые, по мнению автора, не могут не включать ее, поскольку эти феномены непосредственно связаны с выбором [Emirbayer; Giddens], стратегичностью [Priestley] и направленным, в идеале рефлексивным, действием [Archer 2007].

В период с июня 2019 по декабрь 2020 г. автором было просмотрено не менее 70 статей из баз Scopus и WoS и выбрано 10 статей различного методологического дизайна (включающего количественный, качественный и смешанный исследовательские подходы) для более тщательного анализа и ответа на поставленный исследовательский вопрос. Выбор статей для подробного анализа был чисто субъективным и основывался на таких критериях, как: 1) интересная постановка проблемы, несхожесть с другими отобранными статьями; 2) методологический репертуар (предпочтение отдавалось статьям с количественным либо смешанным методом и большой выборкой респондентов); 3) отсутствие теории агентивности в качестве теоретической рамки.

В заключение сформулирован вывод: ни одно из включенных в мониторинг исследований не берет в качестве рамки теорию агентивности, но все они могут быть включены в дискуссию о данной социологической теории, поскольку последняя находит отражение во всех феноменах - структурных, культурных и индивидуальных, которые сопровождают процесс цифровизации работы учителя и освоения им относящихся к этому процессу компетенций.

22 Для нового научного термина «agency» (англ.) в русском языке пока нет устоявшегося перевода, поэтому дан авторский перевод; аналогом можно назвать термин «субъектность» (без ссылок на конкретных авторов, поскольку на русском языке этот феномен автором не изучался). 


\section{1. Агентивность учителя}

Понятие агентивности учителя активно исследуется в течение последнего десятка лет с различными эпистемологическими подходами и преимущественно с помощью качественных методов исследования [Biesta; Edwards; Vähäsantanen]. Проистекая из социологического дискурса о дуальности динамики «индивидуального действия» и «структуры», когда первое меняет последнюю и, в свою очередь, «во втором акте» [Stetsenko] изменяется само [Archer 2013; Giddens], дискуссия об агентивности учителя имеет преимущественно прагматический оттенок, ставя целью понять, какой должна быть среда, выражаемая в: 1) государственной политике; и 2) организационной культуре, для того, чтобы учитель как «агент изменений» [OECD; Heijden] действовал «агентивно». Агентивность учителя в данном контексте ассоциируется с «новаторством» [Toоm 2015], «умением действовать креативно», «в соответствии с высшими профессиональными ценностями» [Edwards], «во благо общества, учащихся и организации» [lbid]. Агентивный учитель, согласно финским исследователям [Toom 2015, 2017; Pietarinen], склонен разнообразить свой педагогический репертуар, ориентирован на прогрессивные методики и сам является активным обучающимся, всегда улучшая собственную практику [Priestley]. Однако агентивным учитель может быть и в практиках противостояния идеям и реформам [Vähäsantanen], а также в рутинизации собственных практик и их репродукции [Billet; Priestley; Lai]: то, что со стороны может выглядеть, как «плыть по течению», для самого учителя может требовать неимоверных усилий и подбора качественных стратегий, поддерживающих его профессиональные ориентации (или профессиональный модус вивенди [Archer 2007]), значимые для его собственной профессиональной идентичности [Eteläpelto 2013].

В большинстве международных исследований агентивность учителя обладает «трансформирующей силой» [Edwards; Toom 2015, 2017; Hökkä], она способна менять как самого учителя, так и его среду, которая, в свою очередь, продвигает учителя еще дальше, в значительной степени подготавливая его для последующих трансформаций. В частности, такого взгляда на агентивность учителя придерживается социокультурный субъектно-ориентированный подход к изучению агентивности [Eteläpelto 2013]. В наименьшей степени исследователи говорят об агентивности учителя как о «репродуцирующей силе», направленной на репликацию или рутинизацию практик [Archer 2007, 2010, 2013], хотя ряд исследований, посвященных социологическому понятию агентивности, подтверждают, что модус вивенди любого агента (не только в профессиональном поле, но и в поле жизни) поддерживается его определенными персональными «опасениями и запросами», которые проистекают в первую очередь из его рефлексий о том, что для него является значимым на определенном отрезке пути [lbid], и именно они определяют выбор его «агентивной стратегии» [lbid].

Резюмируя, под агентивностью учителя мы будем понимать его способность делать ситуативный выбор, действовать направленно и стратегично, ориентируясь на собственные профессиональные ценности и «запросы», а также способность к трансформации ситуации, даже если выбор этой ситуации не был им определен [Archer 2010, 2013; Emirbayer; Priestley]. 


\section{2. Международные исследования о цифровых компетенциях учителей и место агентивности в них}

Современные международные исследования в области цифровой грамотности учителей (включая учителей начальной ступени обучения) многообразны и используют различные эпистемологические подходы и методологические инструментарии. В основном они концентрируются на таких темах, как:

1) выявление взаимосвязей между уверенностью учителя в своих силах и его подходом к обучению (конструктивистский против консервативного) с его ИКТ-компетенциями и уровнем их освоения [Sangkawetai];

2) выявление взаимосвязи ИКТ-аттитюдов и реального применения технологий в классе [Valtonen; Håkansson Lindqvist; Admiral];

3) определение влияния организационной культуры и лидерства на успешное освоение ИКТ учителями [Håkansson Lindqvist];

4) нащупывание связи между стратегиями обучения с ИКТ-аттитюдами [Admiral; Spiteri; Wu];

5) выявление взаимосвязи между способностью учителя профессионально развиваться с помощью ИКТ и влиянием такой модели развития на непосредственное применение технологий на практике [Као];

6) определение уровня стресса учителей при использовании технологий в зависимости от их уверенности в ИКТ [Dong];

7) выделение навыков «цифровой безопасности» учителя и его умения критически оценивать контент, спровоцированный применением ИКТ [Tomczyk].

Результаты исследований, сконцентрированных на перечисленных темах, противоречивы, но все они затрагивают общие феномены.

Так, в работе [Sangkawetai], со ссылкой на ряд уже проведенных исследований [Russell; Fraillon], утверждается, что одной из основных причин недостаточного использования ИКТ в классе является низкая уверенность педагога в собственных навыках [Lee], в то время как высокий уровень такой компетенции способствует применению новых стратегий обучения, которые мотивируют учащихся и приводят к более высоким результатам. Авторы утверждают, что интеграция ИКТ в методики и структуру урока зависит от того, насколько стратегия учителя ориентирована на ученика. Такая структура включает методы глубокого обучения (методы, направленные на поиск учащимся собственного смысла в обучении и его «свободу» в постижении материала [Entwistle], личностно-ориентированный подход и активное применение ИКТ). Все это, по мнению авторов [Sangkawetai], способствует более быстрому освоению когнитивных навыков, ИКТ также позволяет учащемуся самостоятельно конструировать полученные знания и выбирать для этого подходящие технологические инструменты, которые создают связь между полученным знанием и реальным миром. Количественное исследование было проведено на выборке из 1857 педагогов направления STEM (Science, Technology, Engineering, Mathematics - предметы естественно-научного цикла) в 619 различных школах Таиланда [lbid]. К основным результатам можно отнести следующие: установлена положительная взаимосвязь между личной уверенностью учителя в своих силах, его уверенностью в собственном владении ИКТ и структурой преподавания в классе. Личная ИКТ-уверенность педагога показала положительную взаимосвязь 
с методами погружения и личностно-ориентированным подходом. Сравнивая учителей начальной и средней ступеней обучения, авторы пришли к выводу, что для обеих когорт ИКТ-уверенность является наилучшим предиктором использования методик глубокого обучения [Entwistle] с активным применением ИКТ и личностно-ориентированным подходом. Однако для учителей начальной ступени вышеперечисленные компоненты сочетались с методикой обучения, ориентированной на результаты; для учителей же средней ступени данные компоненты коррелировали со структурой урока (его целями и задачами), ориентированной на освоение учащимися мастерства, что предполагает не соревновательный аспект (сравнение результатов учащихся), а направленность на их собственное понимание материала, как и их мотивацию к обучению [Sangkawetai]. Стоит отметить, что авторы исследования не включают теорию агентивности ни в обзор литературы, ни в интерпретацию результатов, хотя личностно-ориентированный подход в преподавании, как и ряд других новаторских методик, как правило, активно обсуждается [Soini; Toom 2015] в связи с наличием «агентивной позиции» учителя в классе.

Исследование, проведенное в Швеции [Håkansson Lindqvist], акцентирует внимание не только на выявлении взаимосвязей между педагогическими стратегиями, но и на прямом влиянии организационной культуры школы, в частности фигуры лидера организации, на успешное освоение учителями педагогических технологий. Дизайн исследования включал заполнение директорами «журналов саморефлексий» [Moon] и дальнейшее проведение полуструктурированных интервью с 32 директорами участниками национальной программы Швеции для директоров школ [Håkansson Lindqvist]. Исследование напрямую не включало концепцию учительской агентивности, и авторы пришли к заключению о необходимости формирования адекватной среды организации, необходимой для успешного приобретения учителями ИКТ-компетенций, аналогичной такой «благоприятной среде», которую, например финские исследователи [Toоm $2015,2017]$, считают обязательной для развития агентивности. В частности, директора подчеркивали, что для того, чтобы иметь возможность повышать свои ИКТ-знания, учителям необходим такой капитал организации, как «коллегиальность», «совместное обучение коллегами друг друга», «дискуссии как новый способ передачи информации». Результаты исследования показали, что директора воспринимают процесс цифровизации школы как комплексную концепцию, которая затрагивает результаты обучения, цифровизацию учебных планов, непрерывное повышение квалификации учителей в области ИКТ и увеличение использования технологий на уроках. Внедрение такой концепции неизбежно ведет к повышению не только цифровых, но и педагогических, административных и лидерских компетенций самих директоров. При этом повышение квалификации всего учительского состава влечет за собой и непрерывное повышение качества знаний и ИКТ-навыков учащихся как обязательное условие для успешного использования ИКТ-компетенций учителя в классе.

Авторы [Admiral] выявили несколько типов учителей в зависимости от их готовности сопротивляться инновациям или, наоборот, внедрять технологии в свой педагогический репертуар. Исследования в области представлений учителей о подходах к преподаванию, упоминаемые авторами, сконцентрированы вокруг парадигм так называемого фронтального 
обучения (или традиционных методов, где акцент делается исключительно на передачу знаний) и «личностно-ориентированного обучения», направленного на самостоятельное конструирование знаний учащимися и их совместное творчество, ассоциируемое с конструктивистским подходом. Использование информационных технологий в классе авторы связывают именно с конструктивистским подходом, однако эмпирических оснований для уверенного утверждения такой взаимосвязи недостаточно. В качестве примера авторы ссылаются на исследование 1120 учителей начальной школы в Тайване [Liu], большая часть которых заявили, что придерживаются личностно-ориентированного подхода в преподавании, но не ассоциируют его с конструктивистской методикой с применением технологий. Лонгитюдное исследование, проведенное в Австралии [Orlando 2013] также подтвердило на выборке из пяти учителей начальной и средней школы, что принятие личностно-ориентированной модели в обучении не означает применение информационных технологий в комбинации с конструктивистским подходом, который ассоциируется с ориентацией на учащегося и его собственный процесс построения индивидуального знания через открытие [Vygotsky].

В конкретном исследовании типологизация учителей была проведена на выборке из 1609 учителей в 59 школах Нидерландов. Учителям было предложено ответить на вопросы, связанные с технологическими инновациями, внедряемыми в их школах согласно государственной программе поддержки технологических инноваций в комбинации с личностно-ориентированным подходом [Admiral]. Анализ результатов дал возможность разделить респондентов на пять кластеров, включавших разное количество человек выборки, эти кластеры и послужили основанием для типологизации учителей по их представлениям о подходах к преподаванию и использованию технологий:

1-й тип - «учитель, применяющий личностно-ориентированный подход и использующий технологии» (444 респондента): в этой выборке большую часть составляли мужчины, находящиеся в середине карьеры (6-20 лет опыта преподавания);

2-й тип - «учитель, настроенный критично к использованию технологий в школе» (296 респондентов): несмотря на позитивную корреляцию с личностно-ориентированным подходом и использованием технологий на практике, эта когорта тем не менее относилась критично к использованию технологий в своей школе, в основном это учителя, находящиеся в середине карьеры (6-20 лет опыта преподавания);

3-й тип - «учитель, испытывающий дискомфорт в применении технологий» (398 респондентов): в этой выборке оказались учителя (в основном женщины) в возрасте от 51 года и более, с опытом работы не менее 11 лет;

4-й тип - «учитель, не принимающий личностно-ориентированное обучение» (344 респондента): эта группа учителей характеризовалась низким средним значением по показателю «личностно-ориентированное обучение», но высокой уверенностью в использовании технологий в обучении, в кластер вошли в основном мужчины с небольшим опытом преподавания;

5-й тип - «учитель с ярко выраженной критической позицией» (120 респондентов): эта группа характеризовалась критичным отношением как к личностно-ориентированному подходу, так и к использованию технологий. Уверенные в том, что результаты обучения зависят исключительно от учащегося, 
а не от усилий учителя, представители этой когорты являлись преимущественно педагогами со стажем более 30 лет, подвергающими сомнению любые инновации в классе, способные поколебать неприкосновенность фигуры учителя.

Стоит отметить, что типологизация учителей по кластерам также сочеталась с исследованием их убеждений о том, что они считают «эффективной преподавательской практикой»; соответственно, не только частое или редкое использование ИКТ, но и выбор «фронтальной подачи» в пользу конструктивистских подходов обозначался ими как оптимальный. Хотя авторы исследования никаким образом не акцентируют внимание на учительской агентивности, здесь мы видим явное подтверждение того, что учителя могут быть одинаково агентивны как в новаторстве, так и в выборе консервативных траекторий работы.

Ряд публикаций [Spiteri; Tezci] также обнаруживают, что на аттитюды, знания и навыки учителей влияет прежде всего организационная культура школы. Культура, которая направлена на качество преподавания, которая позволяет учителям работать в сотрудничестве и делиться знаниями, в большей степени поощряет использование ИКТ [Hsu; Tondeur]. При этом, когда учителя чувствуют, что они уважаемы и их работа ценится, их мотивация использовать технологии, как правило, выше [lbid]. Согласно данным таких исследований, для того чтобы педагоги начальной ступени образования активно использовали технологии на своих уроках, необходимы ИКТ-компетентные лидеры, а также соответствующая техническая поддержка, которая будет способствовать желанию внедрять технологии на уроке [Omwenga; Tezci]. Ряд исследований дифференцируют программы на «традиционную» учебную программу и учебную программу с применением технологий, где последняя является более сложной и разнообразной и всегда ведет к инновациям в преподавании предмета [Aesaert]. Авторы [Spiteri] утверждают, что использование технологий в преподавании не обусловлено возрастом учителя, но обусловлено стажем работы и опытом. Так, учителя, опыт которых не превышает пяти лет, как правило, используют технологии в своей педагогической практике реже, чем более опытные их коллеги [Gu], что противоречит упомянутой ранее типологизации учителей, выведенной нидерландскими исследователями. Многие исследования указывают на так называемый «конфликт девайсов», когда учителя преподают и одновременно все еще сами обучаются использованию ИКТ в преподавании [Orlando 2016], что значительно затрудняет интеграцию ИКТ с уроком [Wake]. Социальные установки учителей в отношении ИКТ влияют на частоту применения этих технологий в классе. Их уверенность в себе и вера в то, что технологии важны для обучения, - главные факторы, влияющие на интеграцию ИКТ в процесс обучения, эти же факторы влияют и на то, с какой степенью уверенности ИКТ применяют учащиеся [Al-awidi; Wastiau]. Однако компаративное исследование [Wu] ряда продвинутых образовательных систем (Финляндия, Шанхай, Сингапур, Тайвань и Южная Корея) выявило, что высокий уровень владения определенными, даже самыми сложными, навыками ИКТ со стороны учителя не всегда отражает его положительное отношение к обязательному внедрению и обучению таким навыкам. В выборку данного исследования вошло 1197 респондентов: 406 из материкового Китая, 143 из Сингапура, 153 из Финляндии, 341 из Тайваня, 154 из Южной Кореи. Все учителя материкового Китая были из Шанхая - города центрального подчинения. Так, несмотря на высокое владение 
навыками Python среди учителей Южной Кореи и Сингапура, согласно исследованию [lbid], в выборке именно учителя из этих стран были не согласны с внедрением навыков программирования в школе при непосредственной поддержке учителя, который бы сопровождал процесс их освоения. На вопрос, как именно лучше изучать навыки программирования, представители всех стран согласились, что лучшие способы подачи материала — это практические задачи по написанию кода, визуальные методы программирования, построение робототехники и проведение занятий в специальных клубах за стенами школы. При этом представители Шанхая (52\%) полностью согласны с тем, что изучать программирование необходимо в пределах школы под руководством учителя, в то время как представители Финляндии (35\%) и Сингапура (25\%) считают, что лучше это делать за ее пределами. Также большая часть учителей из Китая (55\%) и часть учителей из Тайваня (37\%) полностью убеждены, что такой навык можно получить с помощью книг и специализированных веб-ресурсов, с чем не согласны учителя из Финляндии (40\%), Сингапура (20\%) и Южной Кореи (23\%). Стоит отметить, что во всех перечисленных странах внедрение обучения таким навыкам начинается в начальной школе, а в Сингапуре даже на более ранней ступени [lbid]. Интересно отметить и то, что самым позитивным суждением относительно важности развития навыков будущего, включая «компьютерное мышление», обладали представители Шанхая, хотя учителя этой выборки и не являлись самыми грамотными в данной области. В исследовании прослеживается попытка авторов связать социальные установки учителей с их реальными педагогическими практиками, а по его результатам очевидно, что в области овладения технологиями социальные установки и реальные практики учителей не всегда связаны. Хотя в данном исследовании, как и в предыдущих, не применялась теория агентивности, оно показало, что учитель может иметь убеждения относительно важности каких-либо компетенций, однако далеко не всегда его профессиональный модус вивенди включает программу действий по овладению данным мастерством.

Исследователи взаимосвязи ИКТ-аттитюдов с самоэффективностью при выборе стратегий профессионального развития и умением профессионально развиваться через интернет-источники среди 368 педагогов начальной школы в Тайване [Као] пришли к выводу, что интернет-самоэффективностью можно назвать «веру в собственную способность использовать Интернет для эффективного осуществления каких-то целей». Эта вера включает способность учителя как обрабатывать цифровые источники, так и активно взаимодействовать с другими пользователями в Интернете в процессе совместного прохождения курсов профессионального развития. Интересен вывод, что учителя с обширными интернет-практиками имели более позитивное отношение к интеграции информационных технологий в процесс обучения и более активно и результативно участвовали в онлайн-курсах профессионального развития, нежели учителя, которые использовали Интернет не так часто. В данном случае не аттитюды влияют на «агентивное» обучение (которое происходит по инициативе учителя и является значимым для него), а, наоборот, сначала учитель накапливает цифровой опыт и вслед за этим формируется доверительное отношение к использованию технологий в развитии собственного репертуара.

Согласно [Dong], технологии могут быть причиной фрустрации, если учитель не готов к «технологически обоснованной педагогике». Такую фрустра- 
цию ряд ученых называют «технострессом» [Joо]. Техностресс определяется как «современный синдром адаптации, вызванный неспособностью справляться с новыми компьютерными технологиями адекватным образом» [Brod, p. 16]. Он ведет к негативным проявлениям, таким как чувство тревоги, умственное утомление, скептицизм, неэффективное поведение [Dong]. В ряде исследований также выявлено, что недостаток внешней поддержки (техническая поддержка, ассистирование) и низкий уровень собственных способностей (ИКТ-грамотности, умственных способностей) всегда были предикторами техностресса [Fuglseth; Salanova]. Также в исследовании [Al-Fudail] обнаружено, что учителя испытывали техностресс в моменты, когда возникало несоответствие между их личными характеристиками (способности, нужды) и технологической поддержкой в школе (техническая поддержка, обучение). Опираясь на социальную когнитивную теорию [Bandura 1986], которая тесно взаимосвязана с теорией человеческой агентивности [Bandura 2001], авторы [Dong] утверждают, что вера учителей в свою способность справляться со сложностями, связанными с технологиями, влияет на их чувства и установки относительно интеграции технологий в процесс преподавания.

Данные, собранные в рамках исследования в Шанхае среди 375 учителей, подтвердили, что снижению техностресса способствует как административная, так и коллегиальная поддержка, а также общий уровень педагогического технологического контент-знания. При этом стресс может возникать, когда запрос на компетентность учителя в области технологий превышает имеющийся у него компетентностный арсенал [Fuglseth]. Примечательно, что авторы использовали социальную когнитивную теорию, которая легла в основу объяснения психологом Альбертом Бандурой [Bandura 1986, 2001] эффективности человеческого действия, его саморефлексии, умения предсказывать горизонт будущего и действовать агентивно; но теория агентивности напрямую ими не обсуждалась.

\section{Заключение}

Целью данной работы было выявление роли «агентивности учителя» в его цифровом опыте через призму ряда отобранных международных исследований, посвященных цифровой грамотности учителей и приобретению цифровых навыков. Основной целью автора было выявление агентивности учителя в тех исследованиях, которые напрямую никак к данной теории не относились, а были сконцентрированы на поиске потенциала учителя в его ИКТ-стратегиях и овладении им цифровыми компетенциями. Поскольку автор придерживается той позиции, что «агентивное действие» [Emirbayer] возможно во всех моделях поведения - не только в трансформирующих и новаторских, но и в тех, которые удерживают учителя от новаторства (в частности, при определении педагогического репертуара), его внутренней гипотезой было предположение о том, что теория агентивности так или иначе будет прослеживаться во всех исследованиях цифрового поведения учителей, поскольку эти исследования находятся на стыке разговоров о «трансформации» и «репродукции», при столкновении нового и рутинного. На деле ни в одном из отобранных исследований агентивность учителя не упоминалась напрямую, хотя именно способность учителя быть агентивным 
является рычагом, дающим смелость в освоении нового [Eteläpelto 2017], как и активной репродукции значимых рутинных паттернов [Billet]. Тем не менее имплицитно все исследования, посвященные приобретению и наращиванию ИКТ-экспертности среди педагогов, так или иначе отсылают к теории агентивного действия.

Эти исследования показали, что:

1) учителя должны иметь достаточный запас саморефлексии, чтобы быть способными обучаться цифровым технологиям и внедрять их в классе;

2) учителя склонны применять методы обучения, которые считают значимыми, и это не всегда напрямую связано с их положительным отношением к ИКТ, то есть их стратегии могут быть не только трансформирующими, но и репродуцирующими (в выборе привычных методик преподавания, например);

3) учителя лучше осваивают ИКТ, если коммуницируют друг с другом и открыты как к обмену, так и к передаче опыта; таким образом, коллективное действие способно к большей трансформации, чем индивидуальное;

4) освоение цифровых навыков учителями требовательно к окружающей их среде - она должна быть поддерживающей и благоприятной, тогда технологии не будут восприниматься как источник стресса, а будут способствовать профессиональному саморазвитию и положительному изменению.

Комбинация всех перечисленных феноменов активно обсуждается в теории агентивности, и именно они характеризуют «агентивное поведение» учителя. Однако заметим, что качественное «цифровое действие» связывается исключительно с разнообразием, инновационностью, усложнением и улучшением, а значит, в большей степени с трансформацией, чем с репродукцией. Это может означать, что к исследованию учительского цифрового поведения, цифрового обучения и цифровых компетенций больше подошла бы парадигма «субъектно-ориентированного социокультурного подхода» (подробнее об этом см. [Eteläpelto 2013, 2017]), который предлагает взгляд на учителя как на «активного агента, способного обучаться через всю жизнь» [lbid], или «теория морфогенеза» Маргарет Арчер, которая в противовес ее тезису о «морфостазе» выделяет агентов, способных менять своими действиями социальный дизайн [Archer 2013].

К основным ограничениям исследования, описанного в этой главе, можно отнести субъективный способ формирования выборки: все отобранные для анализа зарубежные работы основаны на субъективной исследовательской позиции и ограничены рамками объекта исследования начальной школы. Другим ограничением, связанным с субъективностью, может быть сама цель исследования. Автор допускает, что поиск определенной концепции в статьях, где исследование этой концепции не было изначально заявлено их авторами, может выглядеть методологически необъективным. Между тем стоит отметить и потенциал такого эксперимента. Реально допустить, что применяемая стратегия позволяет расширить возможности для изучения того, что широкое социологическое понятие «агентивность» может лежать в основе различных теорий, которые применялись для изучения совершенно разных, отличающихся от этого понятия явлений, таких как «цифровые навыки», «цифровые компетенции», «цифровые аттитюды», «цифровое поведение», «цифровые отношения» учителей. 


\section{Литература}

1. Admiral W. Teachers in School-based Technology Innovations: A Typology of Their Beliefs on Teaching and Technology / W. Admiral, M. Louws, D. Lockhorst, T. Paas [et al] // Computers and Education. 2017. V. 114. P. 57-68. D0l: https://doi.org/10.1016/j.compedu.2017.06.013

2. Aesaert $K$. The content of educational technology curricula: a cross-curricular state of the art/K. Aesaert, R. Vanderlinde, J. Tondeur, J. van Braak // Education Technology Research and Development. 2013. V. 61(1). P. 131-151. D0l: https://doi.org/10.1007/s11423-012-9279-9

3. Al-Awidi H. M. The effect of student teaching experience on preservice elementary teachers' self-efficacy beliefs for technology integration in the UAE / H. M. Al-Awidi, I. M. Alghazo // Educational Technology Research and Development. 2012.V. 60 (5).P. 923-941. Dol: https://doi.org/10.1007/s11423-012-9239-4

4. Al-Fudail M. Investigating teacher stress when using technology / M. Al-Fudail, H. Mellar // Computers \& Education. 2008. V. 51 (3).P. 1103-1110. D0l: https://doi.org/10.1016/j.compedu.2007.11.004

5. Archer M. Conversations About Reflexivity. Routledge, 2010.

6. Archer M. Making our Way through the World: Human Reflexivity and Social Mobility. Cambridge : Cambridge University Press, 2007.

7. Archer M. Social Morphogenesis. Dordrecht: Springer, 2013.

8. Bandura A. Social cognitive theory: an agentic perspective // Annual Review of Psychology. 2001. V. 52. P. $1-26$.

9. Bandura A. Social foundation of thought and action: A social-cognitive view. Englewood Cliffs, NJ : Prentice-Hall, 1986.

10. Biesta G. How is agency possible? Towards an ecological understanding of agency-as-achievement (Working Paper 5) / G. Biesta, M. Tedder. Exeter : The Learning Lives Project, 2006.

11. Billett S. Subjectivity, self and personal agency in learning through and for work // The SAGE handbook of workplace learning / M. Malloch, Cairns, K. Evans. SAGE Publications Ltd, 2011. P. 60-72. D01: https:// www.doi.org/10.4135/9781446200940.n5

12. Brock. Structure, Culture and Agency: Selected Papers of Margaret Archer (1st ed.)/T. Brock, M. Carrigan, G. Scambler. Routledge, 2016. DOl: https://doi.org/10.4324/9781315678870

13. Brod C. Technostress: The human cost of the computer revolution. Boston : Addison Wesley Publishing Company, 1984.

14. Dong Y. Exploring the Structural Relationship Among Teachers' Technostress, Technological Pedagogical Content Knowledge (TPACK), Computer Self-efficacy and School Support / C. P. Kao, Y. T. Wu, Y. Y.Chang [et al] // Asia-Pacific Edu Res. 2020. V. 29. P. 147-157. D0l: https://doi. org/10.1007/s40299-019-00461-5

15. Edwards A. Recognizing and realizing teachers' professional agency // Teachers and Teaching. 2015. V. 21. No. 6. P. 779-784. DOI: https://doi: 10.1080/13540602.2015.1044333

16. Emirbayer M. What is agency? / M. Emirbayer, A. Mische // American Journal of Sociology. 1998. V. 103. P. 962-1023. D0l: https://doi.org:10.1086/231294

17. Entwistle N. Approaches to study and perceptions of university teaching-learning environments: Concepts, measures and preliminary findings / N. Entwistle, V. McCune, J. Hounsell. 2002 [Электронный ресурc]. URL: www.ed.ac.uk/et//docs/ETLreport1.pdf. (date of access: 12.07.2021).

18. Eteläpelto A. Emerging Conceptualizations on Professional Agency and Learning // Agency at Work. Professional and Practice-based Learning / ed. by M. Goller, S. Paloniemi. 2017. V. 20. Springer, Cham. D0l: https://doi.org/10.1007/978-3-319-60943-0_10

19. Eteläpelto A. Identity and Agency in Professional Learning / A. Eteläpelto, K. Vähäsantanen, P. Hökkä, S. Paloniemi // International Handbook of Research in Professional and Practice-based Learning / ed. by S. Billett, C. Harteis, H. Gruber. Springer, Dordrecht : Springer International Handbooks of Education, 2014. DOl: https://doi.org/10.1007/978-94-017-8902-8_24

20. Eteläpelto $A$. What is agency? Conceptualizing professional agency at work / A. Eteläpelto, K. Vähäsantanen, P. Hökkä, S. Paloniemi // Educational Research Review. 2013. V. 10. P. $45-65$. 
21. Fraillon J. [et al]. International computer and information literacy study: ICILS. 2013 [Электронный ресурc].URL:http://www.iea.nl/fileadmin/user_upload/Publications/Electronic_versions/ICILS_2013_ Technical_Report.pdf (date of access: 12.07.2021).

22. Fuglseth $A$. The effects of technostress within the context of employee use of ICT / A. M. Fuglseth, Ø. Sørebø // Computers in Human Behavior. 2014. V. 40 (40). P, 161-170. D0l: https://doi.org/10.1016/j. chb.2014.07.040

23. Giddens $A$. The constitution of society: Outline of the Theory and Structuration. University of California Press, 1984.

24. GuX. Meeting the "digital natives": Understanding the acceptance of technology in classrooms / X. Gu, Y. Zhu, X. Guo // Journal of Educational Technology \& Society. 2013. V. 16 (1). P. 392-402. D0I: https:// www.jstor.org/stable/jeductechsoci.16.1.392

25. Håkansson Lindqvist M. Digitalization and school leadership: on the complexity of leading for digitalization in school / M. Håkansson Lindqvist, F. Pettersson // International Journal of Information and Learning Technology. 2019. V. 36 (3). P. 218-230. D0l: https://doi.org/10.1108/ IJILT-11-2018-0126

26. Heijden H. R. M. A. van der. Characteristics of teachers as change agents / H. R. M. A. van der Heijden, J. J. M. Geldens, D. Beijaard, H. Popeijus // Teachers and Teaching. 2015. V. 21 (6). P. 681-699. D0I: https://doi.org/10.1080/13540602.2015.1044328

27. Heikonen L. Student-teachers' strategies in classroom interaction in the context of the teaching practicum / L. Heikonen, A. Toom, K. Pyhältö, J. Pietarinen, T. Soini // Journal of Education for Teaching. 2017. V. 43 (5). P. 534-549. DOI: https://doi.org/10.1080/02607476.2017.1355080

28. Hökkä P. Teacher educators' collective professional agency and identity - Transforming marginality to strength / P. Hökkä, K. Vähäsantanen, S. Mahlakaarto // Teaching and Teacher Education. 2017. V. 63. P. 36-46.

29. Hsu S. The impact of multilevel factors on technology integration: The case of Taiwanese grade 1-9 teachers and schools / S. Hsu, P. Kuan // Educational Technology Research and Development. 2013. V. 61 (1). P. 25-50. D0l: https://doi.org/10.1007/s11423-012-9269-y

30. Joo Y. J. The effects of secondary teachers' technostress on the intention to use technology in South Korea / Y. J. J00, K. Y. Lim, N. H. Kim // Computers \& Education. 2016. V. 95. P. 114-122. D0I: https:// doi.org/10.1016/j.compedu.2015.12.004

31. Kao C. P. Understanding Web-Based Professional Development in Education: The Role of Attitudes and Self-efficacy in Predicting Teachers' Technology-Teaching Integration / C. P. Kao, Y. T. Wu, Y. Y.Chang [et al] // Asia-Pacific Edu Res. 2020.V.29. P. 405-415. D01: https://doi.org/10.1007/s40299-019-00493-x

32. Lai C. Teacher Agency and Professional Learning in Cross-Cultural Teaching Contexts: Accounts of Chinese Teachers from International Schools in Hong Kong / C. Lai, Z. Li, Y. Gong // Teaching and Teacher Education. 2016. V. 54. P. 12-21. D0l: https://doi.org/10.1016/j.tate.2015.11.007

33. Lee $Y$. Enhancing pre-service teachers' self-efficacy beliefs for technology integration through lesson planning practice / Y. Lee, J. Lee // Computers \& Education. 2014. V. 73. P. 121-128.

34. Liu S. H. Factors related to pedagogical beliefs of teachers and technology integration // Computers \& Education. 2011. V. 56. P. 1012-1022. D0l: https://doi.org/10.1016/j.compedu.2010.12.001

35. Moon J. A. Learning Journals // A Handbook of Reflective Practice and Professional Development. 2nd ed. London and New York, NY : Routledge Taylor \& Francis Group, 2006.

36. OECD. TALIS 2018 Results (Volume I): Teachers and School Leaders as Lifelong Learners. Paris : TALIS, OECD Publishing, 2019. D0l: https://doi.org/10.1787/1d0bc92a-en

37. Omwenga E. Assessing the influence of the PTTC Principal's competency in ICT on the teachers' integration of ICT in teaching Science in PTTCs in Nyanza Region, Kenya / E. Omwenga, C. Nyabero, L. Okioma // Journal of Education and Practice. 2015. V. 6. No. 35.

38. Orlando J. Digital natives come of age: the reality of today's early career teachers using mobile devices to teach mathematics / J. Orlando, C. Attard // Mathematics Education Research Journal. 2016. V. 28 (1). P. 107-121. Dol: https://doi.org/10.1007/s13394-015-0159-6 
39. Orlando J. ICT-mediated practice and constructivist practices: Is this still the best plan for teachers' uses of ICT? // Technology, Pedagogy and Education. 2013. V. 22. P. 231-246. D0I: https://doi.org/10.1080/ 1475939X.2013.782702

40. Pietarinen J. Teacher's professional agency — a relational approach to teacher learning / J. Pietarinen, K. Pyhältö, T. Soini // Learning: Research and Practice. 2016. V. 2 (2). P. 112-129. D0l: https://doi.org/ 10.1080/23735082.2016.1181196

41. Priestley M. Teacher Agency: An Ecological Approach / M. Priestley, G. Biesta, S. Robinson. London : Bloomsbury Academic, 2015.

42. Russell M. Examining teacher technology use: Implications for preservice and in-service teacher preparation / M. Russell, D. Bebell, L. O'Dwyer, K. O'Connor // Journal of Teacher Education. 2003. V. 54 (4). P. 297-310.

43. Salanova $M$. The dark side of technologies: Technostress among users of information and communication technologies / M. Salanova, S. Llorens, E. Cifre // International Journal of Psychology. 2013. V. 48 (3). P. 422-436. DOI: https://doi.org/10.1080/00207594.2012.680460

44. Sangkawetai C. Predictors of K-12 Teachers Instructional Strategies with ICTs / C. Sangkawetai, J. Neanchaleay, R. Koul, E. Murphy // Technology, Knowledge and Learning 2018. V. 25. P. 149-177 [Электронный ресурс]. URL: https://link.springer.com/article/10.1007\%2Fs10758-018-9373-0 (date of access: 12.07.2021).

45. Soini T. What contributes to first-year student teachers'sense of professional agency in the classroom? / T. Soini, J. Pietarinen, A. Toom, K. Pyhältö // Teachers and Teaching. 2015. V. 21(6). P. 641-659.

46. Spiteri M. Literature Review on the Factors Affecting Primary Teachers' Use of Digital Technology / M. Spiteri, S.-N. Chang Rundgren // Tech Know Learn. 2020. V. 25. P. 115-128. D0I: https://doi. org/10.1007/s10758-018-9376-x

47. Stetsenko A. Radical-Transformative Agency: Continuities and Contrasts with Relational Agency and Implications for Education // Front. Educ. 2019. V. 4. P. 148. D0l: http://doi:10.3389/feduc.2019.00148

48. Tezci E. Turkish primary school teachers' perceptions of school culture regarding ICT integration // Educational Technology Research and Development. 2011. V. 59(3). P. 429-443. DOI: https://doi. org/10.1007/s11423-011-9205-6

49. Tom czyk $Ł$. Skills in the area of digital safety as a key component of digital literacy among teachers // Educ Inf Technol. 2020. V. 25. P. 471-486. DOI: https://doi.org/10.1007/s10639-019-09980-6

50. Tondeur J. Responding to challenges in teacher professional development for ICT integration in education / J. Tondeur, A. Forkosh-Baruch, S. Prestridge, P. Albion, S. Edirisinghe // Educational Technology \& Society. 2016. V. 19 (3). P. 110-120 [Электронный ресурc]. URL: https://www.jstor. org/stable/jeductechsoci.19.3.110 (date of access: 12.07.2021).

51. Toom A. Early career teachers' sense of professional agency in the classroom: associations with turnover intentions and perceived inadequacy in teacher-student interaction / A. Toom, T. Soini, L. Heikonen, J. Pietarinen, K. Pyhältö // Asia-Pacific Journal of Teacher Education. 2017. D0l: https:// doi.org/10.1080/1359866X.2016.1169505

52. Toom A. Teachers' professional agency in contradictory times / A. Toom, K. Pyhältö, F. Rust // Teachers and Teaching. 2015. V. 21(6). P. 615-623.

53. Vähäsantanen K. Professional Agency, Identity, and Emotions While Leaving One's Work Organization / K. Vähäsantanen, A. Eteläpelto // Professions and Professionalism. 2015. V. 5(3). Dol: https://doi. org/10.7577/pp.1394

54. Valtonen T. Examining Pre-service Teachers Technological Pedagogical Content Knowledge as Evolving Knowledge Domains: A Longitudinal Approach / T. Valtonen, E. Sointu, J. Kukkonen [et al] // Journal of Computer Assisted Learning. 2019. DOI: https://doi.org/10.1111/jcal.12353

55. Vygotsky L. Sobraniye sochinenii. T. 2. Pedagogika, 1982.

56. Wake D. Teacher candidates' perceptions of technology supported literacy practices / D. Wake, J. Whittingham // Contemporary Issues in Technology and Teacher Education. 2013. V. 13 (3). P. 175-206 
[Электронный ресурc]. URL: https://www.learntechlib.org/primary/p/42101/ (date of access: 12.07.2021).

57. Wastiau P. The use of ICT in education: A survey of schools in Europe / P. Wastiau, R. Blamire, C. Kearney, V. Quittre, E. van de Gaer, C. Monseur // European Journal of Education. 2013. V. 48 (1). P. 11-27. DOI: https://doi.org/10.1111/ejed.12020

58. Wu L. Teacher's Perceptions and Readiness to Teach Coding Skills: A Comparative Study Between Finland, Mainland China, Singapore, Taiwan, and South Korea / L. Wu, C.-K. Looi, J. Multisilta [et al] // Asia-Pacific Edu Res. 2020. V. 29. P. 21-34. D0l: https://doi.org/10.1007/s40299-019-00485-x 


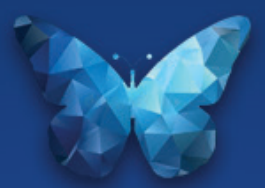

Раздел III

ЭМПИРИКА 



\section{ГЛАВА 5}

\section{Цифровая риторика о «цифре» в образовании}

Дискуссии о влиянии цифровых технологий на развитие школьного образования приобретают в последнее десятилетие рутинный характер. На этапе «пандемического онлайна» в жизни вообще и в образовании в частности (весна 2020 г.) дискуссионный пафос сдвинут в сторону влияния «цифры» не столько на развитие абстрактной системы образования, сколько на развитие «конкретного» ребенка в школе и дома. Смещение вектора рассуждений о пользе и вреде онлайн-образования «от общего к частному» вернуло этим дискуссиям свежесть и актуальность. Виртуальный формат спорных суждений и включенность в тему цифровизации образования публичных персон самого высокого уровня (президент, премьер, руководитель банка, Нобелевский лауреат и др.) подогревают дискуссионный азарт. Этот информационный шум является основанием для формулирования некоторых исследовательских вопросов, ответам на которые и посвящена данная глава монографии:

1) какие информационные сигналы подает обществу цифровая риторика политиков, ученых, бизнесменов в отношении цифровизации образования?

2) как эти информационные сигналы отражаются в сознании потенциальных «агентов изменений», то есть представителей школьного профессионального сообщества, - с чем они соглашаются и чему противостоят?

Под «цифровой риторикой» мы будем понимать мультимедийный формат распространения информации, убеждений, суждений различных персон и коллективов (клубных сообществ), представляющих как собственное мнение о некотором явлении, так и мнение своих коллег, членов презентуемого сообщества.

Рядом с этой расшифровкой можно поставить и другое определение: «Цифровая риторика - это способ информирования, персонификации и вдохновляющего действия через цифровые носители, которые составляются, создаются и распространяются через платформы multimedia» [Цифровая риторика].

Термин «цифровая риторика» мы выбираем из терминологического арсенала Ричарда А. Ленхема [Lanham]. Позже, в 2009 г. Элизабет Лош, теоретик СМИ и специалист по цифровой риторике 23 , определила цифровую риторику в четырех категориях; мы уточняем понимание цифровой риторики, используя две категории по Лош: 1) «условности новых цифровых жанров, которые используются для повседневного дискурса, а также для особых случаев

${ }^{23}$ См.: Элизабет Лош - Elizabeth Losh [Электронный ресурc]. URL: https://ru.abcdef.wiki/ wiki/Elizabeth_Losh (дата обращения: 07.07.2021). 
в жизни среднестатистических людей» и 2) «общественная риторика, часто в форме политических сообщений от государственных учреждений, которая представлена или записана с помощью цифровых технологий и распространяется с помощью электронных распределительных сетей» [Losh].

Исходя из этих предпосылок предложен материал, состоящий из трех информационных пулов.

Первый пул - это сборка простых суждений в отношении явления ци $\phi$ ровизации образования, как позитивных, так и негативных, высказанных публичными людьми и размещенных на цифровых ресурсах. Доступ к прочтению выбранных суждений открыт для каждого пользователя Интернета. Мы выбрали суждения публичных персон из пяти условных представительских кластеров: государственной власти, бизнеса, науки и образования, СМИ, общественности («простых людей»).

Второй пул - сборка ответов от представителей профессионального педагогического сообщества на некоторые суждения, высказанные по поводу внедрения в школьное образование цифровых технологий. Формат опроca - google-анкета, «запущенная» через журнал «Управление качеством образования» в феврале - марте 2020 г.

Третий пул - локальное анкетирование педагогов и родителей одной из школ Санкт-Петербурга, вполне успешно пережившей короткий этап абсолютного «онлайн-образования» и включенной в эксперимент по цифровому образованию для начальной школы.

Без претензии на репрезентативность, объем совокупной выборки 1712 респондентов (в том числе 1401 - по онлайн-опросу из 43 регионов России) в возрасте от 20 до 67 лет из разных типов образовательных организаций и уровней образовательных программ.

Важно было выявить:

- многозначность и/или противоречивость суждений о феномене цифровизации образования, обусловленных личным цифровым опытом и/или наблюдениями за образовательным поведением детей;

- фиксацию рисков, вреда и пользы цифрового обучения;

- неоднозначность отношения кцифровой риторике публичных персон и гипотетический уровень влияния этих риторических суждений на формирование собственного мнения респондентов о перспективах «цифры» в школе.

На данном этапе (лето 2021 г.) исследовательское любопытство было удовлетворено в части сравнения результатов по трем информационным пулам. Выборочная презентация здесь результатов исследования может быть полезна для последующего исследования эволюции цифровой риторики в контексте такого явления, как цифровизация школьного образования.

\section{1. Дискурс риторики (вместо введения в проблему)}

Формат данного раздела монографии ближе к жанру эмпирики без претензии на теоретическое обоснование дискурса риторики. Воспользуемся утверждениями специалиста в этой области и согласимся с тем, что риторика «устанавливает границы правдивости (высказывания) и пытается ответить на вопрос: существует ли между правдой и ложью определенная зона, внутри которой в принципе невозможно ответить — правдиво ли данноеутверждение» [Шатин]. 
Изобретение термина «риторика» приписывают Платону. Однако более адекватное для нашего контекста содержание этого понятия стоит отнести к Аристотелю: «всё дело риторики направлено к возбуждению того или иного мнения... следует заботиться о стиле... стиль оказывается важным вследствие нравственной испорченности слушателя» [Аристотель].

То есть дискурс риторики изначально выступает как орудие в борьбе интересов тех или иных групп влияния.

«Благодаря риторике возникает особая зона коммуникации, которая в прямом смысле слова располагается между правдой и ложью и тем самым определяет специфику этого вида коммуникации» [Шатин]. В этом смысле цифровая риторика не отличается по своим целям от риторики «классической»: здесь так же формируется зона коммуникации с читателем или «смотрителем» ресурса.

Используем простейшую поисковую технологию для выявления популярности темы «цифровизация образования»: при поиске в Яндексе обнаруживаем 5 млн запросов с 7,9 тыс. ежемесячных показов, поисковик Google дает примерно такой же уровень (4,7 млн запросов).

Конкретизируем тему в поисковиках и делаем запрос по словосочетанию «против цифровизации образования»: Яндекс показывает 7 млн запросов против 793 тыс. результатов в Google. В нашу задачу не входит выяснение причин такой количественной разницы по запросам в поисковых системах. Нас больше вдохновляют на исследование популярность темы и противоречивость риторики.

Далее выходим через поисковики на цифровую риторику и запрашиваем у обоих поисковиков информацию, привязанную к обсуждению проблемы цифровизации образования как с позитивной, так и с негативной коннотацией «риторов». В данном случае нам важны персональные высказывания политиков, бизнесменов, ученых, педагогов за период 2019-2021 гг., размещенные в открытом доступе в Интернете, что позволяет нам не нарушать закон о персональных данных.

Контекстные теме смысловые суждения, яркие высказывания мы собрали в таблицу (табл. 3), изложив их последовательно по периодам, а не по формальному статусу персоны, и на основании этих риторических высказываний мы впоследствии сформировали анкету-цитатник для опроса профессиональной педагогической общественности.

Как можно заметить, прочитав высказывания «риторов», за три неполных года (2019-2021) цифровая риторика не изменилась. Не замечено и влияние на цифровую риторику событий, связанных с «черными лебедями» COVID-19, при том что школа в этот период пережила технологический и эмоциональный стресс. Мы не учитываем в цифровой риторике нейтральную позицию, мы разделяем наших риторов на апологетов данности цифрового мира образования и самой жизни человека и, ровно наоборот, оппонентов цифрового мира, не желающих принимать и/или учитывать цифровую данность для образовательных процессов. Эта «эпоха противостояния» часто сравнивается с периодом индустриального саботажа луддитов (1811 г.) в ходе промышленной революции. Длительность процесса сближения суждений двух риторически спорящих сторон относительно цифровизации образования, вероятнее всего, будет связана с отношением самых близких «влиятельных взрослых», то есть педагогов и родителей, к процессу цифровизации образования. 
Высказывания (суждения) публичных персон о цифровизации образования

\begin{tabular}{|c|c|c|}
\hline Дата & $\begin{array}{c}\text { Персона (участник), } \\
\text { событие }\end{array}$ & Цитата или описание смысла со ссылкой на источник \\
\hline 1 & 2 & 3 \\
\hline $\begin{array}{l}\text { Март } \\
2019 \text { г. }\end{array}$ & $\begin{array}{l}\text { Александр Мурашов, про- } \\
\text { фессор кафедры журналистики } \\
\text { Гродненского государственного } \\
\text { университета имени Янки } \\
\text { Купалы, канд. филол. наук, } \\
\text { д-р пед. наук (Беларусь). } \\
\text { Из журнала «Народное об- } \\
\text { разование» }\end{array}$ & $\begin{array}{l}\text { «Цифровизация» образования — попытка устранить живого } \\
\text { человека с его мыслями, чувствами, словами, устранить живую } \\
\text { речь с ее бездонной глубиной, с говорящими паузами, с пульсиру- } \\
\text { ющим биением интонации, живые отношения — из преподавания } \\
\text { и учения; } \\
\text { «...Преподавание станет искусством, преподаватель — рито- } \\
\text { рической личностью. Альтернативы не существует. Все стан- } \\
\text { дартное, очевидное и банальное заберет „цифра“. Все креативно } \\
\text { потентированное останется у человека» }\end{array}$ \\
\hline $\begin{array}{l}\text { Ноябрь } \\
2019 \text { г. }\end{array}$ & $\begin{array}{l}\text { Дмитрий Песков, специальный } \\
\text { представитель Президента РФ } \\
\text { по вопросам цифрового } \\
\text { и технологического развития; } \\
\text { генеральный директор } \\
\text { АНО «Платформа НТИ» } 24\end{array}$ & $\begin{array}{l}\text { «Преимущество ситуации и ее ужас состоят в том, что границ } \\
\text { цифровизации не существует. Нет ни одной сферы деятельности, } \\
\text { которую нельзя было бы полностью перевести „в цифру“»; } \\
\text { "„Цифра“ становится вопросом политическим, и те, кто еще не- } \\
\text { сколько лет назад был ярым сторонником цифровизации, сегодня } \\
\text { обязаны задуматься об ограничителях» }\end{array}$ \\
\hline $\begin{array}{l}\text { Декабрь } \\
2019 \text { г. }\end{array}$ & $\begin{array}{l}\text { Елена Казакова, профессор } \\
\text { СПбГУ, член-корр. РАО, научный } \\
\text { руководитель программы } \\
\text { «Школьная лига РОСНАНО». } \\
\text { Из выступления на конференции } \\
\text { «Школа уходит в цифру» } 25\end{array}$ & $\begin{array}{l}\text { «...Вокруг нас развивается мощный цифровой мир. Наша реаль- } \\
\text { ность давно отрастила второе свое существование. К нашей реаль- } \\
\text { ной жизни добавилась наша виртуальная жизнь. И сегодня мы } \\
\text { не можем мыслить о себе вне контекста: а что при этом проис- } \\
\text { ходит в параллельном виртуальном событии? ... Мы все чаще } \\
\text { рассматриваем наше бытие, воспринимая эти два мира как единое } \\
\text { целое....» }\end{array}$ \\
\hline $\begin{array}{l}\text { Март } \\
2020 \text { г. }\end{array}$ & $\begin{array}{l}\text { Михаил Мишустин, глава } \\
\text { Правительства РФ. } \\
\text { Международный форум } \\
\text { «Цифровое будущее глобальной } \\
\text { экономики»»б }\end{array}$ & $\begin{array}{l}\text { «Нам нужны. .. особые люди, с особыми навыками и особым } \\
\text { опытом, - если хотите „„цифровой спецназ“" правительства»; } \\
\text { «...Цифровые данные — новая нефть XXI века» }\end{array}$ \\
\hline $\begin{array}{l}\text { Апрель } \\
2020 \text { г. }\end{array}$ & $\begin{array}{l}\text { Родители и учителя РФ. } \\
\text { Из открытого письма } \\
\text { В. В. Путину против цифровиза- } \\
\text { ции образования в РФ } 27\end{array}$ & $\begin{array}{l}\text { «Мы, российские граждане, патриоты России: родители, педагоги } \\
\text { и просто неравнодушные люди, налогоплательщики Российской } \\
\text { Федерации, образование которых позволяет оценить преступность } \\
\text { внедрения данной программы, просим остановить финансирова- } \\
\text { ние федерального проекта „Цифровая образовательная среда“ } \\
\text { и остановить внедрение дистанционного обучения в школы, вузы } \\
\text { и другие учебные учреждения» }\end{array}$ \\
\hline $\begin{array}{l}\text { Апрель } \\
2020 \text { г. }\end{array}$ & $\begin{array}{l}\text { Юрий Зинченко, д-р психол. } \\
\text { наук, академик РАО. } \\
\text { Московский международный } \\
\text { салон образования }\end{array}$ & $\begin{array}{l}\text { «...У цифровизации, как у медали, две стороны: с одной стороны, } \\
\text { это возможности, а с другой стороны, это риски, которые надо } \\
\text { учитывать, уметь прогнозировать и минимизировать. Один из } \\
\text { них — деформация традиционных форм социализации ребенка } \\
\text { и подростка» }\end{array}$ \\
\hline
\end{tabular}

24 «Цифровое» образование: пусть никто не останется лишним [Электронный ресурс]. URL: https://www.kommersant.ru/doc/4171063 (дата обращения: 12.06.2021).

25 Школа уходит в цифру? [Электронный ресурc]. URL: https://www.youtube.com/ watch?v=t70ywyYf56I (дата обращения: 10.06.2021).

26 Там же.

27 Открытое письмо Владимиру Владимировичу Путину против цифровизации образования в РФ [Электронный ресурc]. URL: https://docs.google.com/forms/d/e/1FAlpQLSfCyB3DT unt00TPTtCXmLZPHTbc8y9awqPrUK2ibsQew1zWXw/viewform (дата обращения: 07.07.2021). 
Продолжение табл. 3

\begin{tabular}{|c|c|c|}
\hline 1 & 2 & 3 \\
\hline $\begin{array}{l}\text { Июль } \\
2020 \text { г. }\end{array}$ & $\begin{array}{l}\text { Дмитрий Песков, специальный } \\
\text { представитель Президента РФ } \\
\text { по вопросам цифрового и техноло- } \\
\text { гического развития; генеральный } \\
\text { директор АНО «Платформа НТИ» }\end{array}$ & $\begin{array}{l}\text { «...Должна появиться функция цифрового омбудсмена - } \\
\text { не человек, а функция...»; } \\
\text { «Качественное дистанционное образование решает за- } \\
\text { дачу цифровой справедливости для тех, у кого нет доступа к } \\
\text { элитному образованию, потому что оно позволяет ребенку из } \\
\text { отдаленного населенного пункта иметь те же возможности, } \\
\text { что и у ребенка из центральной столичной школы. В этом } \\
\text { смысле дистанционное образование — это воплощенный } \\
\text { цифровой коммунистический рай на Земле. Однако здесь есть } \\
\text { одно ключевое цифровое неравенство —- доступ в Интернет» }\end{array}$ \\
\hline $\begin{array}{l}\text { Сентябрь } \\
2020 \text { г. }\end{array}$ & $\begin{array}{l}\text { Петербургские ученые - участ- } \\
\text { ники круглого стола «Концепция } \\
\text { возрождения образования и науки в } \\
\text { России», Петербургский Дом ученых. } \\
\text { Из открытого письма Президенту РФ } \\
\text { В. В. Путину о категорическом несо- } \\
\text { гласии с политикой Правительства РФ } \\
\text { в сфере образования и науки } 28\end{array}$ & $\begin{array}{l}\text { «В своем обращении академики и профессора требуют } \\
\text { немедленно остановить государственное финансирование } \\
\text { и реализацию проектов вроде„цифровая образовательная } \\
\text { среда“» }\end{array}$ \\
\hline $\begin{array}{l}\text { Ноябрь } \\
2020 \text { г. }\end{array}$ & $\begin{array}{l}\text { Дмитрий Песков, специальный } \\
\text { представитель Президента РФ } \\
\text { по вопросам цифрового и техноло- } \\
\text { гического развития; генеральный } \\
\text { директор АНО «Платформа НТИ»29 }\end{array}$ & $\begin{array}{l}\text { «...Искусственный интеллект должен не замещать учителя, } \\
\text { а быть его помощником»; } \\
\text { «Технология ИИ развивается слишком быстро } \\
\text { и не усваивается обществом. „Слишком быстро“ означает, } \\
\text { что общество не понимает, как развивается технология, } \\
\text { страхи растут гораздо быстрее возможностей»; } \\
\text { «Нам нужны цифровые судьи и цифровые адвокаты» }\end{array}$ \\
\hline $\begin{array}{l}\text { Декабрь } \\
2020 \text { г. }\end{array}$ & «Рамблер» ${ }^{30}$ & $\begin{array}{l}\text { «Цифровая трансформация „с сумом“ больше не является } \\
\text { выбором, а становится условием выживания не только } \\
\text { в условиях конкуренции, но и в ситуации неопределенности» }\end{array}$ \\
\hline $\begin{array}{l}\text { Декабрь } \\
2020 \text { г. }\end{array}$ & $\begin{array}{l}\text { Владимир Путин, Президент России. } \\
\text { Из материалов международной } \\
\text { онлайн-конференции «Artificial } \\
\text { Intelligence Journey» (Al Journey) }\end{array}$ & $\begin{array}{l}\text { «В наступающее десятилетие нам предстоит провести цифро- } \\
\text { вую трансформацию всей страны, всей России, повсеместно } \\
\text { внедрить технологии искусственного интеллекта, анализа } \\
\text { больших данных» }\end{array}$ \\
\hline $\begin{array}{l}\text { Март } \\
2021 \text { г. }\end{array}$ & $\begin{array}{l}\text { 1) } \\
\text { Максим Киселев, генеральный } \\
\text { директор АНО «Развитие челове- } \\
\text { ческого капитала»; } \\
\text { 2) Дзесара Гояева, руководитель } \\
\text { научно-методического отдела } \\
\text { компании ISMART; } \\
\text { 3) Александр Ларьяновский, } \\
\text { управляющий партнер Skyeng. } \\
\text { Из выступлений на Forum.Digital } \\
\text { Education }\end{array}$ & $\begin{array}{l}\text { 1) С приходом диджитализации должна измениться и па- } \\
\text { радигма образования в нашей стране, оно должно стать } \\
\text { более практико-ориентированным; } \\
\text { 2) цифровизация образования вызывает опасения у многих } \\
\text { родителей и учеников; } \\
\text { 3) «Пока мы будем смотреть на учителей как на тех, кого } \\
\text { нужно заставлять что-то делать, - ничего не получится. } \\
\text { Они должны увидеть все те же выгоды от цифровизации, } \\
\text { которые видим мы. Наши учителя должны чувствовать, } \\
\text { что цифровизация им выгодна, что у них никто ничего } \\
\text { не забирает или, что еще хуже, как это чаще всего быва- } \\
\text { ет, не добавляет новую нагрузку» }\end{array}$ \\
\hline
\end{tabular}

28 «От предательства до фашизма»: академики, педагоги и родители выступили единым фронтом против грефовщины и асмоловщины в образовании [Электронный ресурс]. URL: https://narodsobor.ru/2020/10/03/ot-predatelstva-do-fashizma-akademiki-pedagogi-i-roditelivystupili-edinym-frontom-protiv-grefovshhiny-i-asmolovshhiny-v-obrazovanii/ (дата обращения: 07.07.2021).

29 Коленцова Р. «Нам нужны цифровые судьи и цифровые адвокаты» : интервью // Известия. 11 ноября 2020 [Электронный ресурс]. URL: https://iz.ru/1084806/olga-kolentcova/namnuzhny-tcifrovye-sudi-i-tcifrovye-advokaty (дата обращения: 07.07.2021).

30 Рамблер [Электронный ресурc].URL: https://finance.rambler.ru/economics/45524922/?utm_ content=finance_media\&utm_medium=read_more\&utm_source=copylink (дата обращения: 02.07.2021). 
Окончание табл. 3

\begin{tabular}{|c|c|c|}
\hline 1 & 2 & 3 \\
\hline $\begin{array}{l}\text { Апрель } \\
2021 \text { г. }\end{array}$ & $\begin{array}{l}\text { Татьяна Черниговская, профессор } \\
\text { СПбГУ, д-р пед. наук, д-р филол. наук, } \\
\text { член-корр. РАО }\end{array}$ & $\begin{array}{l}\text { «....Мы попали в совершенно другой мир, это цифровой мир } \\
\text { независимо от того, кто как далеко в нем продвинулся... } \\
\text { Искусственный интеллект нас уже „уложил“. Семантический } \\
\text { провал между интуицией и логикой преодолен, и это похоже } \\
\text { на когнитивную атаку» (из выступления на стратегической } \\
\text { сессии «0бразование в цифровую эпоху»)31 }\end{array}$ \\
\hline $\begin{array}{l}\text { Май } \\
2021 \text { г. }\end{array}$ & $\begin{array}{l}\text { Анна Швабауэр, канд. юрид. наук, } \\
\text { эксперт Общественного уполномочен- } \\
\text { ного по защите семьи. } \\
\text { Расширенное заседание думского } \\
\text { Комитета по информационной полити- } \\
\text { ке, информационным технологиям } \\
\text { и связи по вопросам внедрения } \\
\text { в школах «уроков» цифровой грамот- } \\
\text { ности (цифровой гигиены) }\end{array}$ & $\begin{array}{l}\text { «С точки зрения родительского сообщества первая угроза } \\
\text { сейчас — масштабная цифровизация образования, вне- } \\
\text { дрение так называемой цифровой образовательной среды. } \\
\text { Напомню, что против проекта постановления Правительства } \\
\text { о внедрении ЦОС проголосовало } 54000 \text { человек, за было } \\
\text { всего } 400 \text { человек»; } \\
\text { «Перевод на цифровую образовательную среду — удар } \\
\text { по когнитивным и аналитическим способностям наших } \\
\text { детей. И когда говорится, что компьютер - решение любой } \\
\text { задачи, — это ложь, не соответствующая научным, эксперт- } \\
\text { ным и эмпирическим данным» }\end{array}$ \\
\hline $\begin{array}{l}\text { Июль } \\
2021 \text { г. }\end{array}$ & $\begin{array}{l}\text { Виктория Храпова, учитель истории } \\
\text { школы № 998, победитель олимпиады } \\
\text { «Современный московский учитель»32. } \\
\text { Интервью газете «Вести образования» }\end{array}$ & $\begin{array}{l}\text { «Учителю следует постоянно учиться и развивать свои на- } \\
\text { выки, чтобы успевать за современными детьми. Говоря их } \\
\text { же языком, нужно быть ИТ-френдли» }\end{array}$ \\
\hline
\end{tabular}

\section{2. Методология исследования}

На основе смыслов цифровой риторики, представленной в табл. 3, был сформирован «цитатник» из 15 цитат (табл. 4), положенный в основу google-анкеты для опроса педагогов (в том числе учителей, руководителей разных уровней системы общего образования) и родителей. Респондентам предлагалось «согласиться» или «не согласиться» с определенной цитатой. Цитатник был дополнен блоком характеристик будущих респондентов: возраст (для обеих категорий респондентов), опыт (стаж) работы в школе и должность (для педагогов).

Идея опроса - выявить представления педагогической общественности о проблеме цифровизации образования, при том что информационной базой для выявления отношения учителей к феномену цифровизации стала цифровая риторика.

Следует уточнить, что стартовые опросы ${ }^{33}$ в целях исследования были начаты в январе 2020 г., то есть в период до объявления карантинных ограничений в образовательной системе страны и до получения массового опыта дистанционного (в том числе онлайн) образования для всех субъектов образовательных отношений (учеников, учителей, родителей, администраторов).

31 Татьяна Черниговская vs Андрей Курпатов. Образование В Цифровую Эпоху (часть 1) [Электронный ресурc]. URL: https://yandex.ru/video/preview/?text= татьяна черниговская цифровизация школы\&path=wizard \&parent-reqid=1625910825423046-8733384152124559908-vla14663-vla-I7-balancer-prod-8080-BAL-2575\&wiz_type=vital\&filmld=9797845489956373306 (дата обращения: 12.07.2021).

32 «Чтобы успевать за современными детьми, учителю нужно быть ИТ-френдли» : интервью // Вести образования. 9 июля 2021 [Электронный ресурс]. URL: https://vogazeta.ru/ articles/2021/7/9/city_education/17555-moskovskiy_uchitel_rasskazala_kak_byt_v_tsentre_ sovremennyh_pedagogicheskih_trendov (дата обращения: 02.07.2021).

33 Опросы проводились в рамках магистерского исследования по программе обучения «Управление образованием» (направление «Государственное и муниципальное управление») студентки Захаровой (Набоковой) Марии Викторовны. 
Перечень цитат, использованных для опроса

\begin{tabular}{|c|c|}
\hline № цитаты & Текст цитаты \\
\hline 1 & Цифра вошла в нашу жизнь, и никуда от нее не уйти \\
\hline 2 & Раннее знакомство с электронными средствами убивает креативность и талант в детях \\
\hline 3 & Цифровизация не решит никаких проблем школы \\
\hline 4 & $\begin{array}{l}\text { Цифровизация образования — это не что иное, как изменение взаимоотношений между участни- } \\
\text { ками образовательного процесса }\end{array}$ \\
\hline 5 & $\begin{array}{l}\text { Цифровизация образования — это еще один шаг к выращиванию сильно зависимого и некомпе- } \\
\text { тентного поколения }\end{array}$ \\
\hline 6 & $\begin{array}{l}\text { Цифровизация ломает учителя, ломает родителей, ломает детей, а позитивный эффект от цифрови- } \\
\text { зации непонятен }\end{array}$ \\
\hline 7 & $\begin{array}{l}\text { Если мы желаем оцифровать мир образования — надо начинать от начальной школы, именно там } \\
\text { цифровые компетенции формируются моментально }\end{array}$ \\
\hline 8 & $\begin{array}{l}\text { Я вижу прекрасное цифровое будущее, которое облегчает жизнь человека и позволяет ему иметь } \\
\text { свободное время для себя }\end{array}$ \\
\hline 9 & Цифровизация — это путь развития школы, и это востребовано обществом \\
\hline 10 & $\begin{array}{l}\text { Именно учитель В эпоху тотального доступа к любой информации должен научить ребенка алгорит- } \\
\text { му добычи нужной информации }\end{array}$ \\
\hline 11 & $\begin{array}{l}\text { Границ цифровизации не существует. Нет ни одной сферы деятельности, которую нельзя было бы } \\
\text { полностью перевести «в цифру». И нам необходимо задуматься об ограничителях }\end{array}$ \\
\hline 12 & $\begin{array}{l}\text { Цифра — это возможность сделать образование персонализированным, и это лучший из вариан- } \\
\text { Тов для школьника }\end{array}$ \\
\hline 13 & $\begin{array}{l}\text { Следует признать, что реальная ответственность за цифровизацию образования будет за школой, } \\
\text { а значит, за учителем }\end{array}$ \\
\hline 14 & $\begin{array}{l}\text { Все проблемы с цифровизацией школы связаны с тем, что никто не понимает, по каким правилам } \\
\text { будет жить школа при цифровизации }\end{array}$ \\
\hline 15 & $\begin{array}{l}\text { В конечном счете цифровизация обезличит всех нас, мы перестанем дружить, общаться, быть } \\
\text { «человеками»! }\end{array}$ \\
\hline
\end{tabular}

\section{Исследование было разделено на два этапа:}

1) стартовый (январь - февраль 2020 г., то есть до объявления карантина и перехода на онлайн-образование) анкетный опрос профессиональной общественности по российским регионам на предмет суждений педагогов о феномене цифровизации общего образования; выборка составила 1401 человека. Данный опрос проводился в анкетной google-форме через журнал «Управление качеством образования» ${ }^{34}$, подписчиками которого являются руководители и педагоги образовательных организаций регионов РФ;

2) актуальный (апрель - май 2020 г., то есть во время карантина и массового перехода на дистант) анкетный опрос в локальном школьном кластере на примере одной школы, где выборка составила: 65 сотрудников школы (учителя, педагоги дополнительного образования, заместители директора), 246 родителей учащихся.

Блиц-характеристика выборки говорит о том, что мы не претендуем на репрезентативность, так же как не было цели достичь репрезентативности в выборке по цифровой риторике.

34 Научно методический журнал «Управление качеством образования: теория и практика эффективного администрирования» [Электронный ресурc]. URL: https://uko.effektiko.ru/ (дата обращения: 12.07.2021). 
В соответствии с периодами исследования и для удобства описания результатов мы разделили группы респондентов на два кластера. Две группы по периодам опросов получили условные названия «кластер профессиональной общественности» и «локальный школьный кластер».

В целях исследования были сформулированы следующие гипотезы:

1) представления респондентов о феномене «цифровизация в общем образовании» будут различаться по критерию «массового опыта» цифрового образования, так как у первых этого опыта до объявления карантинных ограничений в образовательной системе страны не было, а у вторых такой опыт появился с марта 2020 г., от момента объявления карантина;

2) представления респондентов локального школьного кластера о феномене цифровизации будут различаться по таким критериям, как: возраст (если это родители и/или учителя); опыт (педагогический стаж, если это учителя).

\section{3. Результаты ${ }^{35}$}

Для удобства чтения, при сравнении представлений о цифровизации кластера профессиональной общественности - респондента эпохи «до COVID-19» и локального школьного кластера - респондента эпохи «COVID-19» мы именуем эти две совокупности соответственно «массовый респондент» и «локальный респондент». Будем иметь в виду, что это не просто разные когорты респондентов, но разные «эпохи цифровизации» школьного образования, и обозначим эти условные периоды как «до С-19» и «во время С-19».

Кажется очевидным предварительный прогноз о значимых различиях в представлениях участников о процессе цифровизации не только школьного образования, но жизни человека вообще в периоды «до С-19» и «во время С-19». Однако мы получили не столь однозначную картину: «до С-19» почти половина $(45,3 \%)$ «массового респондента» (кластер профессиональной общественности) согласилась с возможностью «прекрасного цифрового будущего» (цитата № 8), а «во время С-19» таких цифровых оптимистов в «локальном респонденте» (среди учителей и родителей) набралось не более $28,5 \%$ (рис. 14).
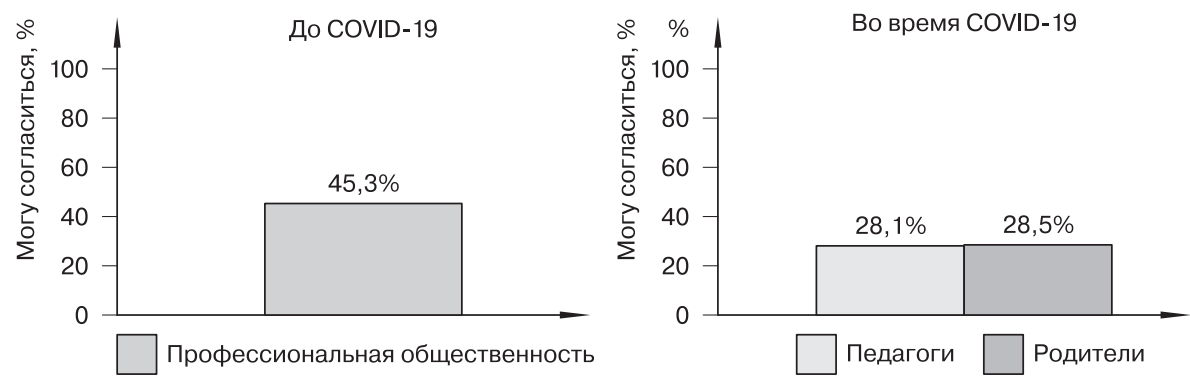

Puc. 14. Распределение ответов по цитате № 8 «Я вижу прекрасное цифровое будущее, которое облегчает жизнь человека и позволяет ему иметь свободное время для себя»

Следующая выбранная цитата (№ 7) должна была дать информацию о некотором совокупном мнении участников образовательных отношений

35 Результаты первого и второго этапов впервые опубликованы: [Заиченко, Набокова]. 
по поводу того, с какого возраста следует оцифровывать обучение школьников. Среди отечественных и зарубежных исследователей диапазон этих мнений находится в границах цифрового старта от трех до 12 лет [Neumann; Kervin]. В нашей выборке мнения респондентов разделились и по периодам опроса, и по категории респондентов (рис. 15). «До С-19» более 60\% респондентов отмечали, что цифровые компетенции следует формировать уже в начальной школе. «Во время С-19» респонденты из локального школьного кластера были более осторожны, и только в 30 случаях из 100 они соглашаются с тем, что возраст начальной школы приемлем для начала формирования цифровых компетенций. При этом учителя более оптимистичны (43,8\% согласившихся), чем родители (30,5\%).
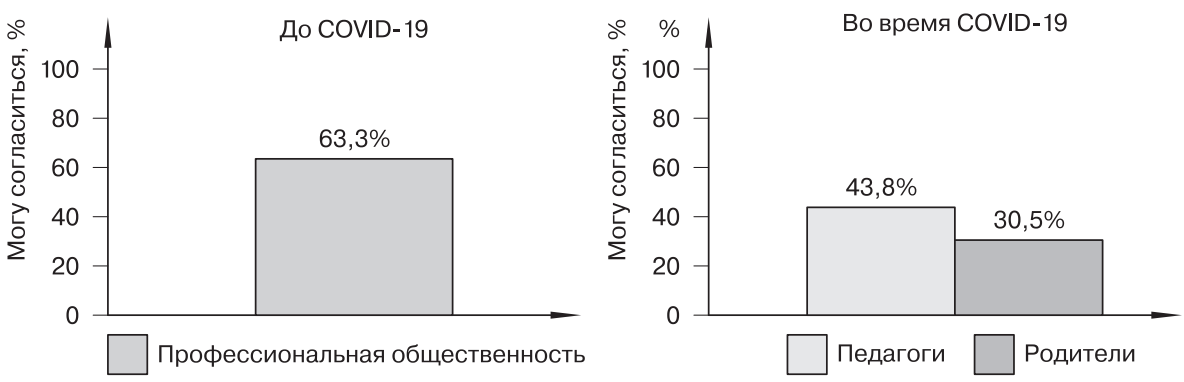

Puc. 15. Распределение ответов по цитате № 7 «Если мы желаем оцифровать мир образования - надо начинать от начальной школы, именно там цифровые компетенции формируются моментально»

Отношение респондентов к потенциалу цифрового образования в смысле его позитивного влияния на развитие форматов персонализированного обучения (цитата № 12) выглядит совсем не оптимистично после того, как они попробовали «жить» в цифровом образовании «во время С-19» (рис. 16). «До С-19» профессиональная общественность в большинстве своем $(61,8 \%)$ верила в потенциал цифровизации в направлении персонализации. Однако на локальном примере «во время С-19» скепсис родителей и педагогов относительно позитивного влияния цифровизации на возможности развития персонализированного обучения оказался чрезвычайно высоким. Абсолютное большинство родителей $(86,6 \%)$ и учителей $(81,2 \%)$, получив первый опыт онлайн-образования (в данной школе многие занятия проводились на платформе Zoom), не согласились с тезисом о положительном влиянии цифровизации на развитие персонализированного обучения.
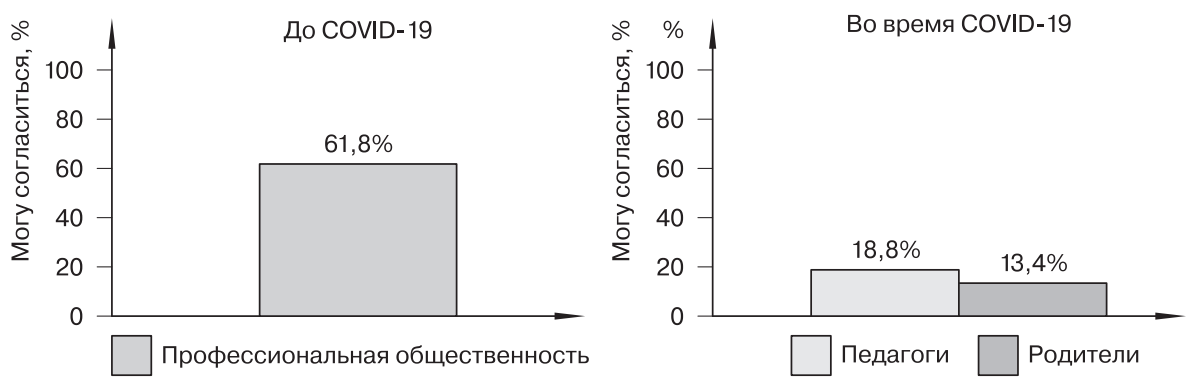

Puс. 16. Распределение ответов по цитате № 12 «Цифрра - это возможность сделать образование персонализированным, и это лучший из вариантов для школьника» 
Также родительский пессимизм оказался выше пессимизма учителей своей же школы и усредненного пессимизма «массового респондента» в отношении того, как цифровизация может повлиять на человеческие отношения (рис. 17).
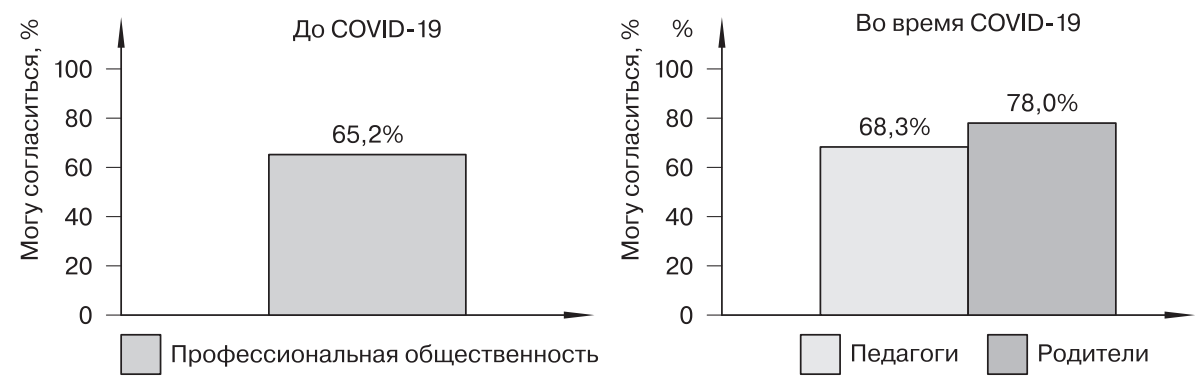

Рис. 17. Распределение ответов по цитате № 15 «В конечном счете чифровизация обезличит всех нас, мы перестанем дружить, общаться, быть „человеками“!»

Заключительным аккордом в этой цепочке представлений респондентов, отвечающих на вопросы анкеты «до С-19» и «во время С-19», может служить выраженное мнение о будущем школы в контексте цифровизации образования (рис. 18). Пережитый этап цифровой жизни школы отразился на представлениях участников образовательных отношений о цифровом будущем школы и общества: меньше половины педагогов и только каждый третий родитель - участники опроса выразили позитивное отношение к будущему «цифрового» школьного образования.
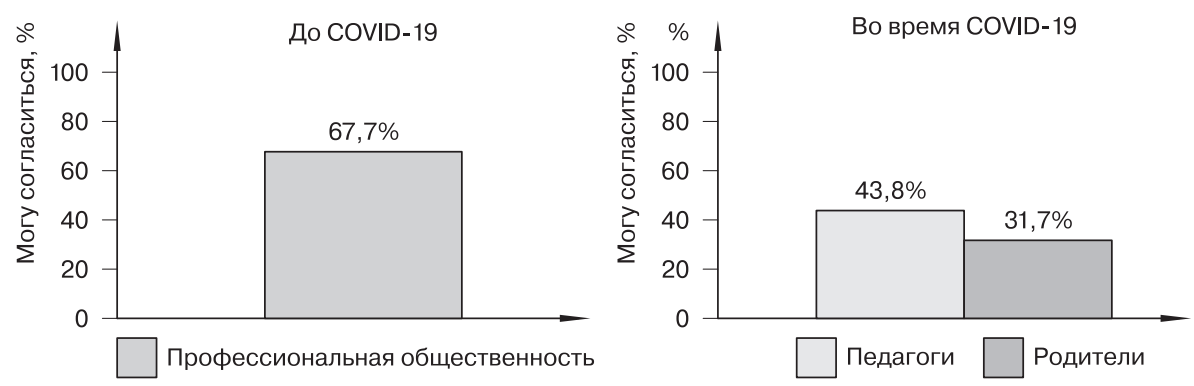

Рис. 18. Распределение ответов по цитате № 9 «Цифровизация — это путь развития школы, и это востребовано обществом»

Блиц-анализ результатов исследования частично подтверждает гипотезу о том, что ответы респондентов, у которых есть опыт «цифрового образования» (педагоги и родители локальной выборки), и других, у которых этого опыта еще не было, различаются. Только примерно каждый третий (28,1 и 28,5\%) из когорты «педагоги и родители, пережившие первые трудности цифрового обучения», соглашается «с прекрасным цифровым будущим, которое облегчает жизнь человека», при этом из массовой когорты «профессиональной общественности» (без опыта «цифрового карантина») каждый второй соглашался с этой цитатой.

Педагоги и родители, прошедшие через опыт «цифрового» карантина, менее оптимистичны в сравнении с «профессиональной общественностью» по поводу того, с какого возраста стоит начинать оцифровывать образование детей: $43,8 \%$ и $30,5 \%$ педагогов и родителей соответственно считают, что 
нужно оцифровать мир образования, начиная с начальной школы, при том что профессиональная общественность в период до карантина соглашалась с этим более чем на 60\%. Одновременно все когорты респондентов в большинстве своем согласны, что «цифровизация нас обезличивает».

В чем единодушны респонденты в своих ответах до и во время С-19 и вне зависимости от категории (представители школьной администрации, учителя или родители), так это в представлениях о том, что «Все проблемы с цифровизацией школы связаны с тем, что никто не понимает, по каким правилам будет жить школа при цифровизации». Причем в период «до С-19» с этим утверждением соглашались около $82 \%$ респондентов, а после получения опыта жизни в цифровом обучении доля таких респондентов снизилась до 76\%.

Для подтверждения второй гипотезы, о различиях в представлениях прошедших через «опыт цифры» и не переживших такой опыт по критериям «возраст» (если это родители и/или учителя) и «опыт» (педагогический стаж, если это учителя), для локальной выборки было проведено анкетирование по 15 цитатам, из них для проверки гипотезы мы выбрали семь цитат: № 1-5, 9, 12 (см. табл. 4), так как именно по ним видны ярко выраженные различия в ответах респондентов.

Так, с утверждением «Цифровизачия образования - это не что иное, как изменение взаимоотношений между участниками образовательного прочесса» (цитата № 4) согласны 100\% учителей, чей педагогический стаж составляет 20 и более лет, и только примерно каждый второй из менее опытных учителей, со стажем до 5 лет (рис. 19).

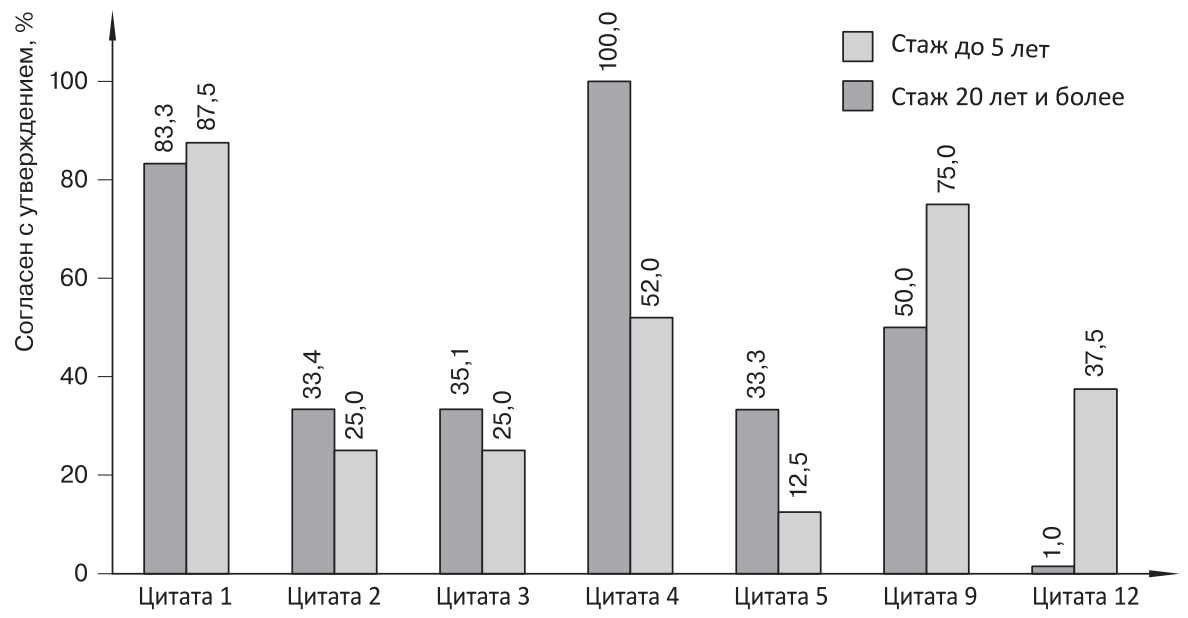

Puc. 19. Распределение ответов «Согласен с утверждением» учителей с разным педагогическим стажем по выбранным цитатам

Большинство респондентов (около 85\%) из локальной когорты учителей с пережитым опытом внезапной цифровизации и ведения уроков в Zoom, вне зависимости от педагогического стажа, согласны с цитатой № 1 «Цифра вошла в нашу жизнь, и никуда от нее не уйти» (см. рис. 19).

Чем моложе учителя, тем реже они соглашаются с цитатой № 2 «Раннее знакомство с электронными средствами убивает креативность и талант в детях» (25\% согласившихся имеют педагогический стаж до 5 лет (см. рис. 19). Их более опытные коллеги (20 и более лет) в 33 случаях из 100 согласны с этим утверждением. 
Рядом по смыслу стоит «проверочная» цитата № 5 «Цифровизация образования - это еще один шаг к выращиванию сильно зависимого и некомпетентного поколения» (см. рис. 19). Наши респонденты подтверждают свое первоначальное суждение о том, что цифра никак не может «убить таланты», а молодое поколение учителей еще в большей степени (их почти 88\%) отрицает утверждение о том, что цифра «выращивает» некомпетентное поколение.

Небольшая разница в представлениях опытных и молодых учителей наблюдается в ответах по цитате № 3 «Цифровизачия не решит никаких проблем школы». Молодые учителя на 75\% верят в то, что цифра сможет решить какие-то проблемы, в отличие от опытных коллег (около 65\%) (см. рис. 19). Но в результате большинство учителей настроены на то, что цифровизация может решить некоторые проблемы школы.

Наиболее полярные представления о феномене цифровизации между опытными и менее опытными учителями, как уже сказано, наблюдаем по цитате № 4 «Цифровизация образования - это не что иное, как изменение взаимоотношений между участниками образовательного процесса» (см. рис. 19). Опытные учителя полностью разделяют такое суждение, и только примерно каждый второй из молодых учителей думает так же.

С цитатой № 9 «Цифровизация - это путь развития школы, и это востребовано обществом» согласны 75\% молодых педагогов, тогда как только половина учителей со стажем 20 лет поддерживают этот тезис (см. рис. 19).

Различия в суждениях респондентов о феномене цифровизации наблюдаются по цитате № 12 «Цифра - это возможность сделать образование персонализированным, и это лучший из вариантов для школьника»: опытные учителя (стаж 20 лет и более) единодушно (99\%) не соглашаются с этим утверждением (см. рис. 19).

Ответы респондентов из группы «родители» первоначально были разделены на четыре подгруппы по возрасту, но поскольку значимых различий между ними по ответам не обнаружено, для презентации мы выделили по критерию «возраст» две подгруппы, примерно равные по количеству ответов: «до 40 лет» и «40 лет и старше». Анкетирование проводилось по тем же 15 цитатам, из которых были выбраны семь цитат, где оказались наиболее выраженные различия в ответах.

Неожиданно самыми заметно различными в «возрастных» подгруппах оказались ответы родителей на цитату № 1 «Цифра вошла в нашу жизнь, и никуда от нее не уйти»: чем старше респондент, тем чаще он соглашается с данным утверждением (почти $82 \%$ против 60\%) (рис. 20).

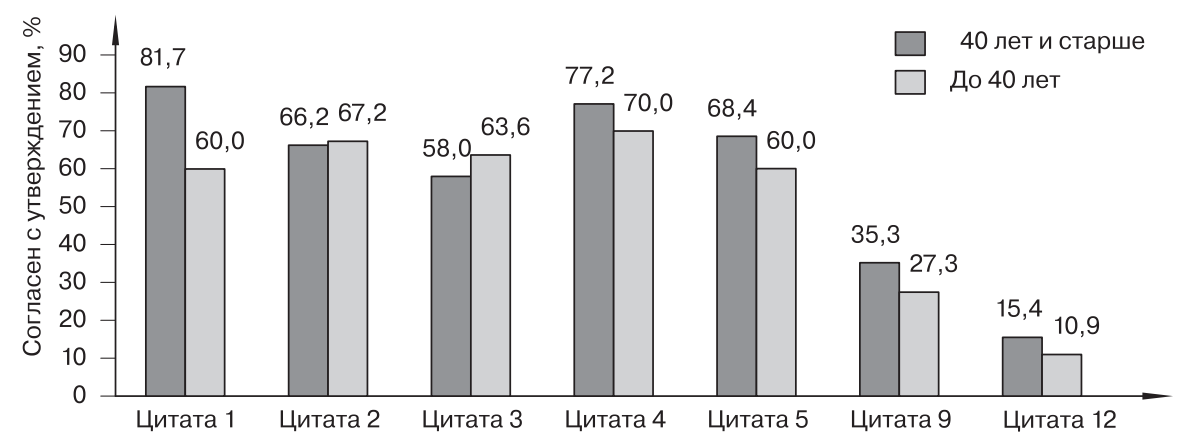

Puc. 20. Распределение ответов «Согласен с утверждением» родителей разного возраста по выбранным цитатам 
Различия в ответах на все другие цитаты оказались незначительными (см. рис. 20). То есть наша гипотеза о том, что возраст родителей будет влиять на их представления о разных аспектах феномена «цифровизации образования», не подтвердилась.

Однако интересно сравнить представления о феномене цифровизации образования когорты родителей с представлениями других респондентов.

Так, например, с цитатой № 1 «Цифра вошла в нашужизнь, и никуда от нее не уйти» соглашаются 92,9\% когорты «профессиональная общественность», более $85 \%$ педагогов, но только 60\% родителей в возрасте до 40 лет поддерживают это суждение. Конфликт представлений учителей и родителей о влиянии цифровизации на подрастающее поколение мы наблюдаем по цитате № 5 «Цифровизация образования — это еще один шаг к выращиванию сильно зависимого и некомпетентного поколения». С этим суждением соглашается каждый третий опытный респондент-учитель со стажем более 20 лет, 10\% молодых учителей, но родители видят риски цифровизации для образования своих детей, и более $60 \%$ родителей соглашаются с данным суждением вне зависимости от возраста.

Возраст не является значимым фактором, но значимой оказывается роль взрослого (учитель или родитель), когда респондент выражает свое отношение к цитате № 9 «Цифрровизация - это путь развития школы, и это востребовано обществом». Чем моложе респонденты-учителя, тем больше среди них согласных с утверждением о востребованности обществом цифровизации школьного образования, и наоборот, чем моложе родители, тем меньше доля согласных с этим утверждением.

Скептически отнеслись родители всех возрастов к цитате № 12 «Цифра это возможность сделать образование персонализированным, и это лучший из вариантов для школьника» (их не более $12 \%$ в среднем), а представители профессиональной общественности, не имевшие опыта онлайн-образования, были согласны с этим утверждением в январе 2020 г. на 38,2\%.

Анализ результатов исследования показал, что учителя с педагогическим стажем 20 лет и более, столкнувшись с опытом «цифрового карантина», оказались более подготовленными к функционированию в цифровых условиях, чем молодые учителя.

\section{4. Заключительный эпизод}

Переходя к заключительным выводам по представленному фрагменту исследования, уточним экспозицию.

Мы не формулировали гипотез, связанных с выявлением зависимостей между цифровой риторикой и опросом педагогической общественности за один и тот же период времени наблюдений. Хотя было бы логично эту связку искать.

В начале главы было поставлено два вопроса:

1) какие информационные сигналы подает обществу цифровая риторика политиков, ученых, бизнесменов в отношении «цифровизации образования?

2) как эти информационные сигналы отражаются в сознании потенциальных «агентов изменений», то есть представителей школьного профессионального сообщества и родителей - с чем они соглашаются и чему противостоят? 
Ответ на первый вопрос может звучать так: 1) цифровая риторика подает противоречивые сигналы обществу по отношению к феномену «цифровизация образования»; 2) цифровая риторика не использует «пандемическую эпоху» в качестве базового аргумента для объяснения необходимости цифры в школе (аналитические материалы и выводы исследований в цифровую риторику мы не включаем).

Ответ на второй вопрос должен быть расшифрован более подробно. Но логично предположить, что если информационные сигналы противоречивы, то и отражение этих сигналов в сознании агентов изменений, умноженное на их личный опыт знакомства с цифрой в школе, будет противоречивым.

В отличие от цифровой риторики в контексте цифровизации образования, где не обнаружен водораздел «до С-19» и «во время С-19», у общества этот раздел ощутим: эффект «С-19» разделяет наших респондентов на тех, кто получил опыт внезапного массового онлайн-обучения, и тех, кто этого опыта не получил.

Из 15 цитат по шести из них (№ 1-5, 15; см. табл. 4) различия в ответах составили менее $10 \%$. Больший интерес представляют цитаты, по которым либо есть ощутимые различия в ответах респондентов, либо единодушно подтверждена потенциальная, ожидаемая респондентами проблема от цифровизации (табл. 5).

Таблица 5

Наиболее значимые цитаты и различия в ответах педагогов в периоды «до C-19» и «во время C-19»

\begin{tabular}{|c|c|c|c|}
\hline \multirow{2}{*}{$\begin{array}{c}\text { № } \\
\text { цитаты }\end{array}$} & \multirow{2}{*}{ Текст цитаты } & \multicolumn{2}{|c|}{ «Согласен», \% } \\
\hline & & «Д० (-19» & «Во время (-19» \\
\hline 6 & $\begin{array}{l}\text { Цифровизация ломает учителя, ломает родителей, ломает } \\
\text { детей, а позитивный эффект от цифровизации непонятен }\end{array}$ & 44 & 56 \\
\hline 7 & $\begin{array}{l}\text { Если мы желаем оцифровать мир образования — надо } \\
\text { начинать от начальной школы, именно там цифровые компе- } \\
\text { тенции формируются моментально }\end{array}$ & 63 & 44 \\
\hline 8 & $\begin{array}{l}\text { Я вижу прекрасное цифровое будущее, которое облегчает } \\
\text { жизнь человека и позволяет ему иметь свободное время } \\
\text { для себя }\end{array}$ & 55 & 28 \\
\hline 9 & $\begin{array}{l}\text { Цифровизация — - это путь развития школы, и это востребо- } \\
\text { вано обществом }\end{array}$ & 68 & 43 \\
\hline 10 & $\begin{array}{l}\text { Именно учитель в эпоху тотального доступа к любой инфор- } \\
\text { мации должен научить ребенка алгоритму добычи нужной } \\
\text { информации }\end{array}$ & 76 & 82 \\
\hline 11 & $\begin{array}{l}\text { Границ цифровизации не существует. Нет ни одной сферы } \\
\text { деятельности, которую нельзя было бы полностью перевести } \\
\text { «в цифру». И нам необходимо задуматься об ограничителях }\end{array}$ & 74 & 60 \\
\hline 12 & $\begin{array}{l}\text { Цифра — это возможность сделать образование персонали- } \\
\text { зированным, и это лучший из вариантов для школьника }\end{array}$ & 62 & 19 \\
\hline 13 & $\begin{array}{l}\text { Следует признать, что реальная ответственность за цифрови- } \\
\text { зацию образования будет за школой, а значит, за учителем }\end{array}$ & 51 & 32 \\
\hline 14 & $\begin{array}{l}\text { Все проблемы с цифровизацией школы связаны с тем, что } \\
\text { никто не понимает, по каким правилам будет жить школа } \\
\text { при цифровизации }\end{array}$ & 82 & 78 \\
\hline
\end{tabular}


В заключительных выводах мы ставим акценты на представлениях респондентов из локального кластера, то есть периода «во время С-19» как переживших практический опыт цифрового образования и, вероятнее всего, более осознанно относящихся к явлению цифровизации образования:

- вне зависимости от стажа педагогической деятельности большинство учителей (около 85\%) считают, что процесс цифровизации школьного образования перешел «точку невозврата» и «цифра прочно вошла в жизнь школы», однако более 70\% учителей, прошедших опыт «цифры», не видят «прекрасного цифрового будущего для школы»;

- педагоги, прошедшие через опыт внезапного дистанционного образования, в три раза ниже оценивают возможности цифры в персонализации образовательного процесса, чем педагоги, не имеющие опыта «жизни в цифре», и в два раза менее оптимистичны по поводу цифрового будущего образования;

- чем моложе учителя и чем меньше их педагогический стаж, тем более оптимистично они настроены на позитивное влияние «цифры» на развитие школы и тем увереннее они в своем мнении о том, что цифровое образование «в помощь развитию детских талантов»;

- чем старше и опытнее учителя, тем больше они соглашаются с суждением о том, что смыслы цифровизации образования связаны прежде всего с изменением взаимоотношений между участниками образовательного процесса, и наоборот, молодые специалисты не видят этой зависимости в сочетании «цифра - отношения»;

- большинство родителей периода «во время С-19» не приветствовали раннее вхождение детей в цифровое образование и согласились с тем, что цифровизация не решает никакие проблемы школы и будет способствовать выращиванию сильно зависимого и некомпетентного поколения; практически никто из родителей не верит в то, что цифровизация сможет перевести систему образования на рельсы персонализированного обучения. При этом чем старше родители, тем чаще они соглашаются с тем, что «цифра прочно вошла в нашу жизнь, и никуда от нее не уйти».

Итак, противоречивость цифровой риторики подтверждается противоречивостью суждений общества (педагогов и родителей) о феномене «цифра в школе». Вне зависимости от того, что, по данным исследований [Цифровая экономика...], только $18 \%$ россиян используют Интернет для чтения газет и журналов (в отличие от $81 \%$ финнов или эстонцев), создается впечатление улавливания сигналов цифровой риторики и абсолютно гармоничной их противоречивости.

\section{Литература}

1. Аристотель. Риторика // Античные риторики. М.,1978. С. 128.

2. Заиченко Н. А., Набокова М. В. Цифровизация — тест на COVID // Народное образование. 2020. № 5. C. 71-80.

3. Цифровая риторика [Электронный ресурс]. URL: http://ru.knowledgr.com/17770875/ ЦифроваяРиторика (дата обращения: 10.07.2021).

4. Цифровая экономика: 2021 : краткий статистический сборник / Г. И. Абдрахманова, К. О. Вишневский, Л. М. Гохберг [и др.] ; Нац. исслед. ун-т «Высшая школа экономики». М. : НИУ ВШЭ, 2021. $124 \mathrm{C}$. 
5. Шатин Ю. Дискурс риторики: между правдой и ложью // Альманах «45 параллель». 2013. № 17(257) [Электронный ресурс]. URL: https://45Il.net/diskurs_ritoriki (дата обращения: 09.07.2021).

6. Lanham R. A. The Electronic Word: Democracy, Technology and the Arts. Chicago : U Chicago P, 1993.

7. Losh E. Virtualpolitik : An Electronic History of Government Media-Making in a Time of War, Scandal, Disaster, Miscommunication, and Mistakes. Cambridge, MA : MIT Press, 2009. 432 p.

8. Neumann M. Using tablets and apps to enhance emergent literacy skills in young children // Early Childhood Research Quarterly. 2018. V. 42. P. 239-246. D0l: 10.1016/j.ecresq.2017.10.006.

9. Kervin L. Powerful and Playful Literacy Learning with Digital Technologies // Australian Journal of Language and Literacy. 2016. V. 39 (1). P. $64-73$. 


\section{ГЛАВА 6}

\section{Цифровое неравенство школ как предмет исследования}

Актуальность проблемы исследования цифрового неравенства школ обусловлена несколькими взаимосвязанными обстоятельствами: процессами цифровой трансформации образования, возрастающими требованиями к цифровому обеспечению школьного образовательного процесса и, соответственно, возрастающими требованиями к цифровой компетентности (грамотности) всех участников образовательных отношений, в первую очередь к тем, кто управляет учебным процессом в школе (администраторы), и к тем, кто учит (педагоги).

Цифровая трансформация образования обострила проблему цифрового неравенства школ, которая особенно проявилась в период глобального кризиса, связанного с распространением COVID-19, когда начался тотальный и экстренный переход школ на дистанционное обучение.

Мы предлагаем некоторые результаты исследования по выявлению признаков цифрового неравенства в региональном разрезе в представлениях респондентов этих регионов.

Цифровое неравенство рассматривается нами с двух точек зрения: неравенство в наличии технических средств (технологчческое неравенство) и неравенство в отсутствии цифровых навыков (компетентностное неравенство) у администрации и педагогов общеобразовательных школ.

Региональная выборка включает несколько территорий, в том числе респондентов мегаполиса - Санкт-Петербурга. Логично было предположить, что ресурсная обеспеченность мегаполиса будет значительно отличаться от ресурсной обеспеченности других региональных территорий. И, возможно, уровень цифровой технологической обеспеченности будет положительно влиять на уровень цифровой компетентности педагогов и администраторов.

В рамках изучения вероятного цифрового неравенства общеобразовательных школ крупного мегаполиса (Санкт-Петербург) и школ российских регионов возникла необходимость поиска ответов на следующую группу исследовательских вопросов:

- Что такое «цифровое неравенство»?

- Каковы факторы, породившие цифровое неравенство?

- Существует ли цифровое неравенство в общеобразовательных школах российских регионов? В чем оно заключается?

- Каково представление школьных администраторов и педагогов общеобразовательных школ об их готовности к изменениям в условиях ци $\phi$ ровизации образовательного процесса?

Мы концентрируемся на понятии «цифровое неравенство» с точки зрения отечественных и зарубежных авторов, даем базовые характеристики 
этого нового явления для исследователей, имеющего множество трактовок. В результате анализа опросов выявляем цифровое неравенство в паре «мегаполис - регион», то есть в общеобразовательных школах мегаполиса (Санкт-Петербург) и школ российских регионов.

\section{1. Теория вопроса}

Понятие «цифровое неравенство», или «цифровой разрыв», стало широко использоваться в последнее десятилетие в исследовательских текстах на старте перехода к новой экономике, «основанной на знаниях» [Уваров], основанной «не на движении товаров, ресурсов, материалов, а на движении идей, движении знаний» [Материалы международного семинара...], связанной с возросшим значением информационно-коммуникационных технологий (ИКТ), проникновением «цифры»в социальную, экономическую, индустриальную и образовательную системы.

Появление нового понятия, как правило, связано с необходимостью не только обозначить новое явление, но и объяснить изменения, происходящие в окружающей действительности, в частности в школьном образовании.

История появления термина и самого явления «цифровое неравенство» (англ. digital divide, digital gap) началась в США на рубеже XX и XXI вв. в процессе информатизации страны. Тогда вышла серия отчетов Национального управления электросвязи и информации Министерства торговли США о результатах исследования использования телекоммуникационных технологий в США, в которых содержалась статистика и фиксировался факт существования цифрового неравенства среди граждан США [Falling Through... 1998, 1999, 2000; A Nation Online... 2002]. В отчетах утверждалось, что «цифровой разрыв», как разрыв между теми, кто имеет доступ к новым технологиям и не имеет такого доступа, «является одной из ведущих проблем страны в области экономических и гражданских прав» [Falling Through... 1998]. Здесь же впервые была проанализирована проблема цифрового разрыва на примере сельских и городских территорий.

Обращаясь к отечественным исследованиям в данной области, выделяем работу Т. М. Шамсутдиновой, где обозначены пять причин, ограничивающих доступ граждан к цифровой инфраструктуре:

1) низкий уровень доходов населения;

2) пожилой возраст;

3) низкий уровень образования;

4) специфическое географическое расположение региона;

5) принадлежность населения к коренным народам (национальным меньшинствам) удаленных территорий [Шамсутдинова].

Появление термина «цифровое неравенство» сопровождается дискуссиями в зарубежных, отечественных научных кругах и в профессиональных педагогических сообществах. Предмет дискуссий - его контекстуальное использование. При описании понятия «цифровое неравенство» исследователи обозначают как минимум шесть потенциальных проблем цифровизации, приводящих к неравенству:

1) наличие/отсутствие физического и/или финансового доступа к использованию современных ИКТ;

2) уровень владения/невладения цифровыми компетентностями; 
3) наличие/отсутствие достаточной технической оснащенности территорий (количество оборудования, качество технического оснащения, а также количество единиц техники на душу населения);

4) целеполагание в использовании ИКТ;

5) возможность и необходимость постоянного образования: обучения, переобучения, повышения квалификации в области освоения ИКТ;

6) управление информационными ресурсами и проектами (создание этого направления обучения и соответствующих программных продуктов для образовательных учреждений в масштабах страны).

Появление русскоязычного термина «цифровое неравенство» в России исследователи связывают с международным семинаром «Проблемы преодоления „цифрового неравенства“ в России и странах СНГ», который состоялся 28 ноября 2000 г. в Москве ${ }^{36}$ [Международный семинар...]. На семинаре была выделена одна из базовых проблем информационного общества, становление которого, с последующей информатизацией общественных процессов, будет связано с «расслоением» социума с точки зрения доступа к информационному пространству. В работе семинара приняли участие представители $\mathrm{OOH}$, федеральных министерств, Совета безопасности, Исполнительного комитета СНГ, исследовательских агентств, коммерческих и общественных организаций, а также эксперты в области Интернета из России и стран СНГ. Участники семинара представили несколько проектов по преодолению цифрового неравенства: обеспечение граждан доступом к информации через сеть Министерства путей сообщения РФ; развитие сети электронной торговли в странах Содружества; создание общественных информационных центров, в которых каждый желающий мог бы бесплатно или за минимальную плату получить доступ к важнейшим информационным ресурсам; либерализация рынка информационных услуг. Правительство России в сотрудничестве с Всемирным банком выказало готовность открыть на одном из государственных сайтов биржу идей для преодоления цифрового неравенства и т. д. Образование предлагалось рассматривать двояко: в качестве «создателя образовательного потенциала - интеллектуальной ресурсной среды информационного общества - с одной стороны и активного организованного потребителя информационных услуг - с другой» [Материалы международного семинара...]. При этом подчеркивалось, что современные информационно-коммуникационные технологии - это всего лишь инструмент для реализации конкретных методов и методик обучения, которые требуют развития и совершенствования. Это касается прежде всего методического обеспечения цифровизации образования.

Английскому термину «digital divide» в русском языке соответствуют как минимум семь понятий: «цифровой барьер», «цифровое неравенство», «цифровое разделение», «цифровой разрыв», «цифровой дисбаланс», а также «информационная изоляция», «информационное неравенство» и др.

Приведем некоторые примеры из всего многообразия трактовок и аспектов изучения понятия «цифровое неравенство».

Так, О. В. Перфильева, рассматривая проблемы цифрового неравенства в 2007 г., характеризовала это явление как «разрыв между теми, кто

36 Международный семинар «Проблемы преодоления „цифрового неравенства“ в России и странах СНГ». Москва, 28 ноября 2000 г. [Электронный ресурс]. URL: https://a-z.ru/gov_ house/8/index.htm (дата обращения: 12.07.2021). 
располагает регулярным и эффективным доступом к современным информационно-коммуникационным технологиям, и теми, кто подобным доступом не располагает» [Перфильева].

Этот же процесс в 2014 г. рассматривался исследователями С. А. Дятловым и Т. А. Селищевой: «Цифровой разрыв (или информационное неравенство) это неравенство в доступе к информационно-коммуникационным технологиям, имеющее своим следствием усиление экономического, социального, культурного неравенства» [Дятлов, Селищева].

В том же году другие исследователи [Кузнецов, Маркова] дали личностноориентированное понимание термина «цифровой разрыв (барьер)»: «зависимость успеха человека от его способности использовать информационнотелекоммуникационные технологии для решения деловых и повседневных задач». По утверждению этих авторов, отсутствие способностей использовать достижения современных ИКТ приводит к цифровому неравенству.

В журнале «Мониторинг общественного мнения: экономические и социальные изменения» предлагаются два подхода к определению цифрового неравенства: неравенство в доступе и неравенство в целях использования [Волченко].

Е. В. Химичук рассматривает цифровое неравенство как многокомпонентное явление, характеризующееся пятью категориями: технической, социально-исторической, экономической, психологической, правовой [Химичук]. Каждой из категорий приписывается собственная значимость. Нельзя сказать, что все предложенные категории рядоположенны.

В нашем понимании цифрового неравенства наиболее адекватными категориями являются «техническая» и, согласно [Химичук], «экономическая»как конфликт между знанием и компетентностью.

Идею цифрового неравенства обозначает еще один термин, предложенный Э. Харгиттаи, - «цифровой разрыв второго уровня» (англ. second-level digital divide), где под вторым уровнем неравенства понимаются различия в цифровых навыках людей [Hargittai].

Таким образом, понятие цифрового неравенства уже выходит за первоначальную трактовку отсутствия физического (технологического) доступа к цифровым технологиям, перейдя в сферу цифровой компетентности.

Как точно замечено, «компетенция - это договорной (консенсусный) ожидаемый результат образования» [Блинов]. Особенности «цифровой компетентности» некоторые авторы трактуют в обязательной связке с компьютерной грамотностью и уточняют, что «конвергенция профессий в цифровую эпоху ведет к стиранию грани между универсальными и профессиональными компетенциями» [Там же]. В результате эти наборы компетенций являются «перетекающими» в зависимости от профессиональной деятельности.

На основе разработок отечественных исследователей ([Лебедев 2020а; Буданцев; Адамович; Сапрыкина, Волохович; Добрякова; Беликов] и др.) мы выделяем восемь компонент цифровой компетентности специалиста:

1) когнитивная - знание основ информационных процессов, места и роли информации в современном обществе; знание методов и средств обработки информации; прикладные знания в области современных ИКТ и систем;

2) деятельностная - умения и навыки в решении профессиональных задач с использованием средств вычислительной техники. Например, умение работы в компьютерных сетях и навыки работы с разнообразным программным обеспечением; 
3) поведенческая - готовность, демонстрируемая на практике, к определению и реализации собственной программы профессионального образования и готовность применять цифровые инструменты в профессиональной и общественной деятельности;

4) мотивационно-ценностная - система ценностных ориентиров на самоопределение, самосовершенствование, профессиональную самореализацию и самопознание своих профессиональных качеств и возможностей в меняющемся обществе, в условиях информатизации социально-экономических процессов; мотивы и модели поведения, ориентированные на ближайшие и отсроченные результаты образовательной деятельности при работе в цифровой образовательной среде;

5) коммуникативная - степень открытости и восприимчивости к чужому опыту; умение построения системы коммуникаций как в обычном межличностном общении, так и с применением современных телекоммуникационных средств;

6) рефлексивная - потребность в рефлексии, в оценке и анализе личного опыта, в осознании смысла педагогической деятельности и своего места в цифровом мире;

7) личностная - определенные личностные качества (ответственность, дисциплинированность, креативность, умение работать в команде, лидерство и др.) и собственный взгляд на то, как процесс цифровизации образования повлияет или может повлиять на характер отношений участников образовательного процесса в контексте дальнейшей информатизации общества;

8) аналитическая - оценивание своей деятельности и ее результатов, интерпретация данных о качестве образовательного процесса и его результатах, критериях оценки результатов образовательного процесса.

Поскольку тема цифрового неравенства - обсуждаемая и актуальная, можно привести еще много примеров исследований различных аспектов этого явления. Мы ограничимся перечислением разнообразных проблем цифрового неравенства, которые исследуют современные авторы:

- методики расчета индекса цифрового неравенства [Архипова, с. 12];

- вопросы регионального цифрового неравенства [Индекс готовности...; Кузнецов, Маркова];

- неравенство для лиц пожилого возраста [Лысенко, Федосеева];

- цифровое неравенство в паре «город - село» [Гайнанов, Шарифьянов; Санникова] и др.

В данном исследовании мы фиксируем под цифровым неравенством общеобразовательных школ два типа неравенства:

1) наличие или отсутствие технических средств обучения в образовательной организации (технологическое неравенство);

2) наличие или отсутствие цифровых навыков у администрации и учителей (компетентностное неравенство).

\section{2. Организация исследования}

Проведенное исследование включало теоретическую и эмпирическую части. Эмпирика собиралась методом онлайн-анкетирования на базе googleформ. Респондентами стали администрация и педагоги 35 общеобразовательных школ Санкт-Петербурга и 27 школ российских регионов. Выборка 
случайная, представлена 1786 респондентами, в том числе 228 - представители административных команд школ более чем из 10 регионов России. В разрезе территорий выборка представлена респондентами поселений городского типа (49 чел.), сельских поселений (29 чел.), остальные респонденты проживают в городах.

Мы бы не стали обобщать результаты, полученные через опросы по данной выборке, на всю генеральную совокупность по характеристике межрегиональных различий. В данном случае мы апробируем количественный подход к исследованию, возможность получения каких-либо особенных характеристик в межрегиональном разрезе в контексте цифровизации школы. На последующем этапе исследования, в 2022 г. мы перейдем на качественный уровень и через фокус-группы с руководителями и индивидуальные интервью с педагогами будем уточнять региональные/территориальные особенности школьной цифровизации.

Этап получения количественных данных методом google-опроса проводился с середины мая по июнь 2021 г. на добровольной и полностью анонимной основе. Анкета включала вопросы для педагогов и администраторов школ с целью проверки того, насколько текущая ситуация в школах соответствует сформулированным гипотезам о цифровом неравенстве. В табл. 6 представлено территориальное расположение респондентов.

Таблица 6

Распределение респондентов по регионам

\begin{tabular}{|c|c|c|c|}
\hline \multirow{2}{*}{ Регион } & \multicolumn{3}{|c|}{ Количество респондентов, чел. } \\
\hline & Bcero & Администраторы & Учителя \\
\hline Санкт-Петербург & 1306 & 158 & 1148 \\
\hline Архангельская область & 15 & 2 & 13 \\
\hline Вологодская область & 15 & 4 & 11 \\
\hline Республика Карелия & 85 & 17 & 68 \\
\hline Псковская область & 34 & 4 & 30 \\
\hline Другие регионы СЗФ0 & 125 & 20 & 105 \\
\hline Алтайский край & 29 & 3 & 26 \\
\hline Московская область & 30 & 1 & 29 \\
\hline Ямало-Ненецкий автономный округ & 137 & 17 & 120 \\
\hline Другие регионы РФ & 10 & 2 & 8 \\
\hline Итого & 1786 & 228 & 1558 \\
\hline
\end{tabular}

Выборка случайная и вполне может быть охарактеризована как репрезентативная: в опросе участвовали педагоги и руководители из всех типов школ и разных территорий (мегаполис, большие и малые города и поселки, села).

Если рассматривать пограничные характеристики в составе респондентов двух групп (педагоги и административные команды), то можно выделить следующее: 1) молодые специалисты (до 30 лет) в составе педагогов занимают долю $22,1 \%$, в административных командах их доля выше и составляет порядка 31\%; 2) группа «пенсионного возраста» (старше 55 и 60 лет) представлена у педагогов как $25,5 \%$, в составе административных работников те, кому за 60 лет, составляют около 10\% (рис. 21). 


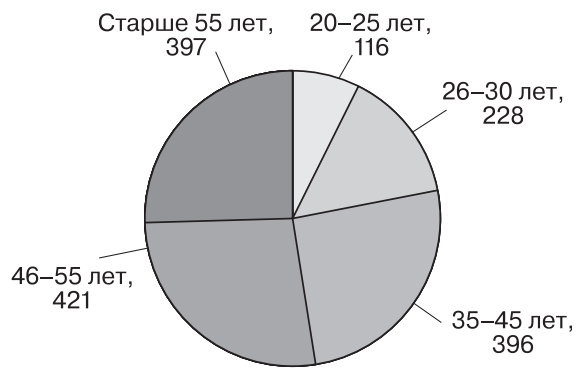

Педагоги

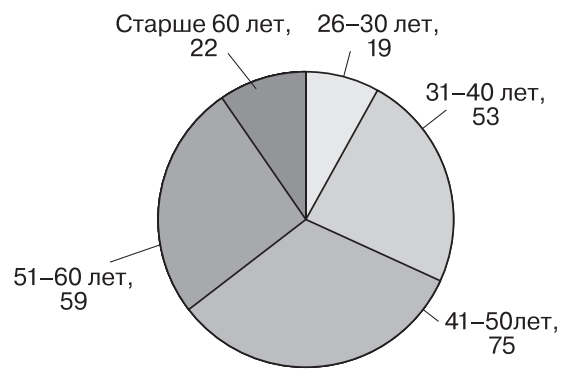

Представители администрации

Puс. 21. Распределение респондентов по возрасту, чел.

В разрезе территорий в паре «мегаполис - регионы» этот показатель дает такую пропорцию: доля «молодых респондентов» в Санкт-Петербурге составила 27\%; в регионах наиболее молодой состав педагогов (до 30 лет) выявлен в Республике Карелия (27\% от общего числа респондентов региона). Самый возрастной регион (педагоги старше 55 лет) - Псковская область (37\% против 27\% в Санкт-Петербурге).

Характеристика выборки по уровню образования респондентов (табл. 7, 8) имеет некоторые незначительные особенности: доля респондентов с высшим образованием составляет в среднем по всей совокупности более 80\%, в том числе в сельских школах (например, в сельской школе Алтайского края высшее образование имеют 25 из 26 преподавателей); респонденты с ученой степенью представлены исключительно Санкт-Петербургом (кроме одного представителя Республики Карелия).

Таблица 7

Распределение респондентов-педагогов по уровню образования

\begin{tabular}{|c|c|c|c|c|c|c|}
\hline \multirow{3}{*}{ Уровень образования } & \multicolumn{6}{|c|}{ Количество, чел. } \\
\hline & \multirow{2}{*}{ Bcero } & \multicolumn{5}{|c|}{ Возраст, лет } \\
\hline & & $20-25$ & $26-30$ & $35-45$ & $46-55$ & 55 и старше \\
\hline Высшее непедагогическое & 167 & 17 & 28 & 47 & 28 & 49 \\
\hline Высшее педагогическое & 1229 & 66 & 184 & 323 & 353 & 303 \\
\hline Среднее специальное & 117 & 20 & 11 & 19 & 30 & 37 \\
\hline Незаконченное высшее & 18 & 12 & 2 & 3 & 1 & - \\
\hline Ученая степень & 23 & 1 & 2 & 11 & 2 & - \\
\hline Прочее & 2 & - & 1 & 1 & - & - \\
\hline
\end{tabular}

Таблица 8

Распределение респондентов - представителей администрации по уровню образования

\begin{tabular}{|l|r|r|c|c|c|c|c|}
\hline \multirow{2}{*}{ Уровень образования } & \multicolumn{7}{|c|}{ Количество, чел. } \\
\cline { 2 - 9 } & \multirow{2}{*}{ Всего } & \multicolumn{7}{|c|}{ Возраст, лет } \\
\cline { 3 - 9 } & & До 25 & $\mathbf{2 6 - 3 0}$ & $\mathbf{3 1 - 4 0}$ & $\mathbf{4 1 - 5 0}$ & $\mathbf{5 1 - 6 0}$ & $\mathbf{6 0}$ и старше \\
\hline Высшее непедагогическое & 40 & - & 5 & 12 & 12 & 8 & 3 \\
\hline Высшее педагогическое & 172 & 2 & 12 & 40 & 57 & 42 & 19 \\
\hline Среднее специальное & 4 & - & 1 & - & - & 3 & - \\
\hline Незаконченное высшее & 1 & - & - & - & 1 & - & - \\
\hline Ученая степень & 11 & - & - & 1 & 5 & 5 & - \\
\hline
\end{tabular}


По территориальному признаку респонденты распределились следующим образом: педагоги и администраторы, работающие в мегаполисе (Санкт-Петербург), - 1306 (73\%), в городах других регионов - 396 (22\%), в сельской местности - 84 (5\%).

С целью выявления возможного цифрового неравенства школ материалы исследования разделены на три части:

1) оснащенность школ компьютерной техникой;

2) доступность и использование педагогическим составом образовательных организаций информационных технологий и средств коммуникации;

3) самооценка педагогами уровня собственного владения цифровыми инструментами.

\section{3. Результаты исследования}

Для анализа ситуации возможного цифрового неравенства школ мегаполиса (Санкт-Петербург) и школ российских регионов респондентам была предложена анкета, содержащая показатели, отражающие, по мнению авторов, ряд характеристик технологического оснащения образовательного учреждения (17 показателей) и характеристики, позволяющие судить о готовности педагогов и представителей администрации школ к работе в условиях цифровой образовательной среды (более 25 показателей).

Анализ результатов опроса администраторов учебных заведений в части оснащенности школ компьютерным оборудованием показал, что практически 100\% школ во всех регионах имеют хотя бы один стационарный компьютерный класс и стационарный компьютер учителя в учебном кабинете, небольшое отклонение отмечено только для двух регионов: Санкт-Петербург (99\% - наличие компьютерных классов и 95\% - наличие компьютера учителя) и Ямало-Ненецкий АО (94\% по обоим показателям).

По другим показателям наличия оборудования для учебного процесса мы можем зафиксировать значительный разброс по разным регионам (рис. 22).

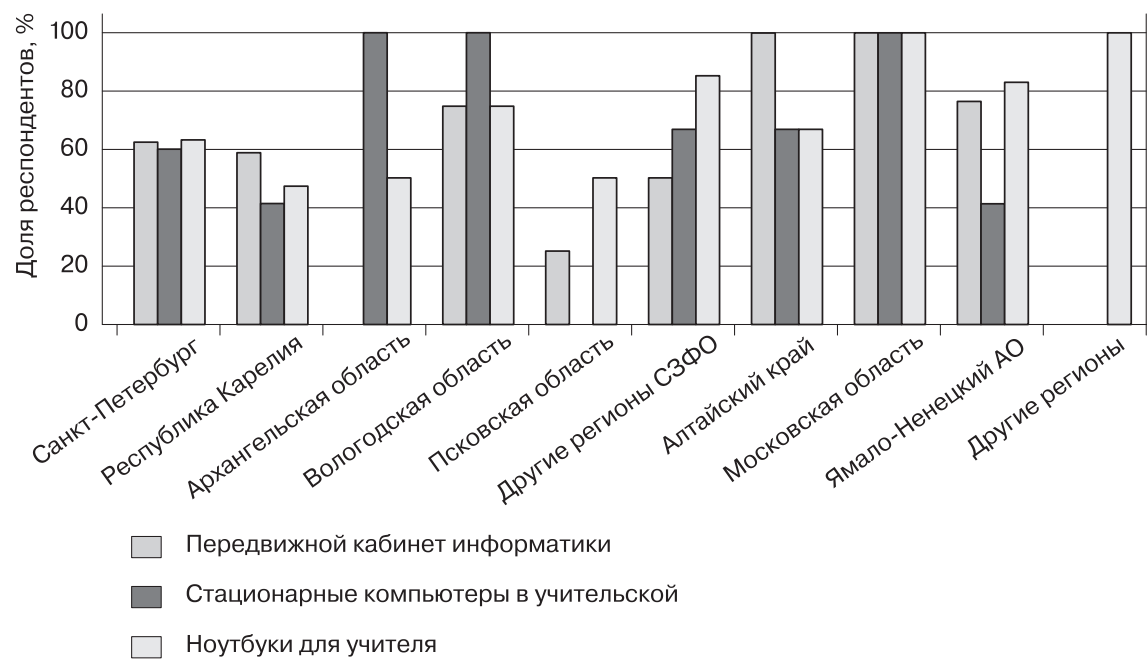

Puc. 22. Распределение респондентов по наличию компьютерного оборудования для организации учебного процесса 
По показателю наличия мобильных кабинетов можно отметить выявленное неравенство между всеми регионами опроса. В Санкт-Петербурге (63\% положительных ответов) не выявлено преимущества перед школами Вологодской области и Ямало-Ненецкого АО (по 75\% положительных ответов) и Алтайского края (100\%) несмотря на то, что в последних двух регионах значительная часть школ расположены в сельских поселениях. Низкая оснащенность мобильными классами отмечена в Псковской области (25\%), полное отсутствие мобильных классов зарегистрировано в школах Архангельской области.

Два других показателя отражают оснащенность компьютерной техникой учителей вне компьютерных и учебных классов. Так, наличие хотя бы одного стационарного компьютера в помещении учительской отметили $60 \%$ респондентов из Санкт-Петербурга. В регионах отмечен существенно более низкий уровень, например, представители Республики Карелия и Ямало-Ненецкого АО дали положительный ответ на этот вопрос в 40 случаях из 100, а в Псковской области положительных ответов не было.

По показателю оснащенности учителей ноутбуками зафиксирован существенный разброс между школами разных регионов. Более низкую оснащенность (по сравнению с Санкт-Петербургом, где получено 63\% положительных ответов) показали школы Республики Карелия (47\%), Архангельской и Псковской областей (по 50\%), а более высокие показатели отмечены в Вологодской области (75\%), Алтайском крае (67\%) и Ямало-Ненецком АО (82\%).

Полученные ответы на вопрос «Как организована сеть в вашей школе?» показали, что в среднем порядка 80\% школ имеют доступ к Интернету (выделенная линия либо бесплатный Wi-Fi, рис. 23). Наилучшие показатели выявлены в Вологодской области (100\% респондентов указали наличие Wi-Fi) и Apхангельской области (более $80 \%$ выбрали вариант «Проводной Интернет» и около $20 \%$ - «Бесплатный Wi-Fi»). Наименьшая доступность к Интернету выявлена в Псковской области (41\% - проводной Интернет и $26 \%$ - Wi-Fi). В то же время зафиксирована в целом низкая оснащенность общеобразовательных школ бесплатным Wi-Fi, включая Санкт-Петербург (23\%), Республику Карелия (13\%) и Алтайский край (16\%). Более высокий уровень беспроводного Интернета (свыше 30\%) отмечен в школах Вологодской и Московской областей, а также в Ямало-Ненецком АО.

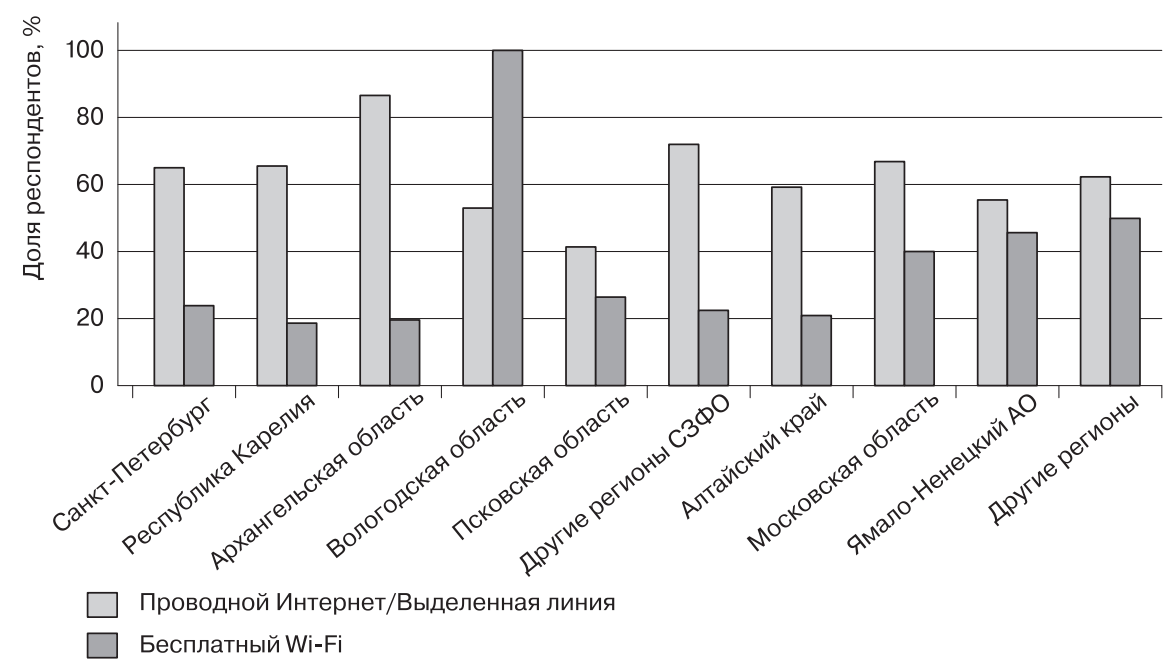

Puc. 23. Оснащенность школ доступом к Интернету 
Близкие данные (порядка 67\%) получены по наличию доступа к Интернету в учебных классах; сильное отклонение от среднего показали только Вологодская область (80\%) и Алтайский край (55\%). В разрезе «город - село» отчетливо видно территориальное неравенство: оснащены Интернетом только 54\% классов сельских школ против 62\% в городских школах. В то же время выявлена обратная зависимость по другим показателям: 50\% школ поселков городского типа предоставляют компьютер педагогу и ученику в свободном доступе (в Санкт-Петербурге - 32\%, в других городах - 39\%) и 54\% сельских и поселковых школ используют компьютер в библиотеке (в СанктПетербурге этот показатель составляет 29\%, в других городах - 36\%). Респонденты из поселковых и сельских школ сообщают о значительно меньшем количестве дополнительной техники для размещения и демонстрации информационных материалов, чем городские респонденты: положительный ответ дали $11 \%$ респондентов сельских поселений, $28 \%$ - в мегаполисе и 19\% - в других городах исследования (рис. 24).

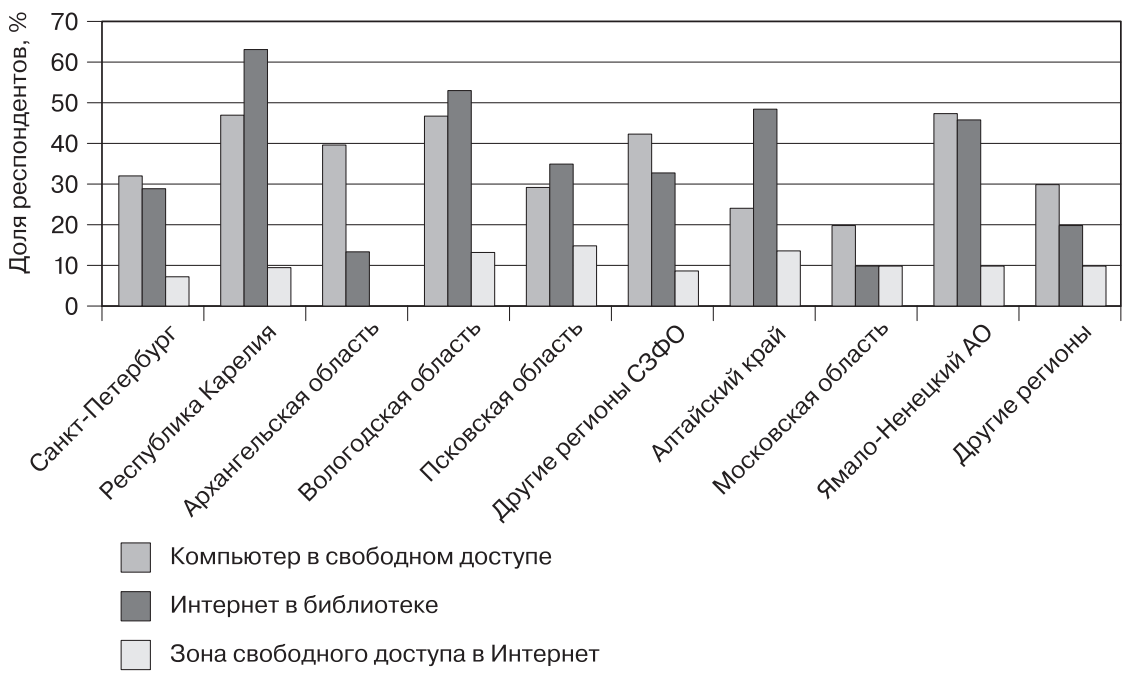

Pис. 24. Предоставление свободного доступа к ПК и Интернету

Положительно ответили на вопрос о наличии техники на рабочем месте с доступом в Интернет в среднем по совокупности 88\% респондентов, при этом максимальное значение (100\% респондентов) зафиксировано в Архангельской области, минимальное (73\%) - в Псковской области. Наличие техники в личном пользовании (дома) отмечают в среднем порядка 90\% и больше респондентов, кроме Республики Карелия (78\%). Однако необходимо отметить, что при общем высоком уровне оснащенности компьютерами (ноутбуками) дома во всех регионах, кроме Архангельской области и ЯмалоНенецкого АО, более $20 \%$ респондентов указали, что эта техника находится не в личном пользовании, а в общем (всей семьи).

Исследование межрегионального неравенства по уровню возможностей использования цифровых образовательных технологий в учебном процессе не дало существенных различий в территориальном аспекте.

В региональном разрезе ответов на вопрос «Участвуете ли вы в сетевых профессиональных сообществах?» вариант «Да, очень часто» во всех регионах разместился между 12 и 20\%. Исключение составили Псковская область 
(3\%) и Ямало-Ненецкий АО (26\%). Самый популярный ответ во всех регионах - «Да, но редко».

Отмечаем, что в региональном разрезе реже других принимают участие в сетевых профессиональных сообществах респонденты из Псковской области (40\%) и Алтайского края (46\%) против 32\% «неучаствующих» в сетевых сообществах представителей школ Санкт-Петербурга. Вероятнее всего, эта особенность в ответах респондентов связана с тем, что значительная их часть работают в сельских школах (в Алтайском крае все респонденты - представители сельских школ, в Псковской области сельские школы составляют примерно 25\%).

Анализ ответов по показателю сетевой активности в возрастном разрезе показывает «прямую зависимость»: чем старше респонденты, тем активнее они в сетевых сообществах (табл. 9).

Таблича 9

Распределение ответов учителей на вопрос

«Участвуете ли вы в сетевых профессиональных сообществах?», \%

\begin{tabular}{|l|c|c|c|c|c|}
\hline \multirow{2}{*}{\multicolumn{1}{c|}{ Вариант ответа }} & \multicolumn{5}{c|}{ Возраст, лет } \\
\cline { 2 - 7 } & $\mathbf{2 0 - 2 5}$ & $\mathbf{2 6 - 3 0}$ & $\mathbf{3 5 - 4 5}$ & $\mathbf{4 6 - 5 5}$ & $\mathbf{5 5}$ и старше \\
\hline Да, очень часто & 7 & 11 & 13 & 21 & 17 \\
\hline $\begin{array}{l}\text { Редко (для поиска конкретной информа- } \\
\text { ции, получения консультации) }\end{array}$ & 5 & 49 & 53 & 50 & 53 \\
\hline Не знаю, что такое сетевое сообщество & 16 & 5 & 3 & 1 & 1 \\
\hline Нет & 72 & 35 & 31 & 28 & 29 \\
\hline
\end{tabular}

Наиболее яркое разделение по региональному признаку получено в ответах респондентов на вопрос «Владеете ли вы навыками онлайн-преподавания?» (рис. 25). При сопоставлении данных по регионам видны принципиальные различия между вариантами ответов. На основании имеющихся данных невозможно выявить устойчивую тенденцию, которая объединяла бы все регионы. Обращает на себя внимание парное сходство между Вологодской и Московской областями, Санкт-Петербургом и другими регионами СЗФО. Вновь выделяются ответы когорты респондентов Псковской области и Алтайского края (логично предположить, что и здесь проявляется влияние территориального компонента в разрезе «село - город»): не владеют навыками онлайн-преподавания 42,3\% респондентов сельских школ (школы мегаполиса и городов - 10\%), и только 11,5\% респондентов сельских поселений выбрали ответ «Да, и применяю это на практике» (школы мегаполиса и городов - в среднем 45\%).

Не менее существенно выражены различия в уровне владения навыками онлайн-преподавания между преподавателями разных возрастных групп. Так, около 60\% учителей в возрасте 26-30 лет ответили, что владеют этими навыками и применяют их на практике. Среди учителей не старше 25 лет и в когорте 35-40 лет ответивших так - до 50\%. А вот в возрастной группе старше 40 лет положительные ответы были получены только у $40 \%$ респондентов. Ответ «Нет, не владею» выбрали 6\% учителей до 30 лет и 12\% учителей старше 35 лет. 


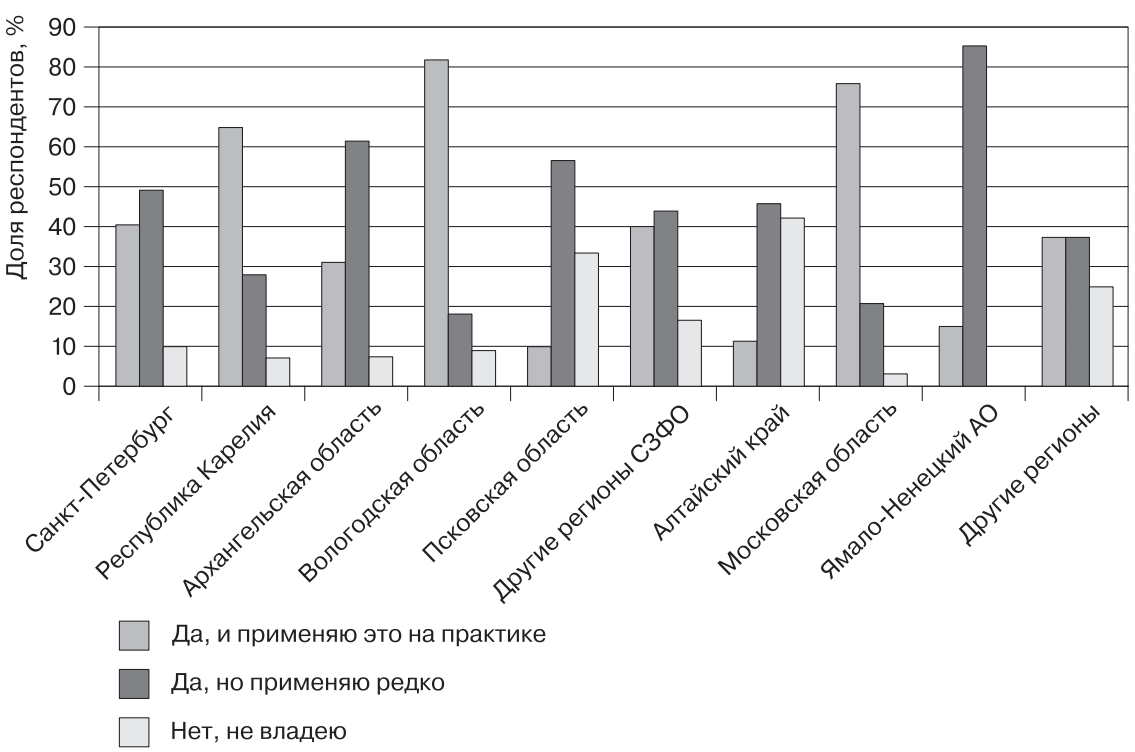

Puc. 25. Распределение ответов респондентов на вопрос «Владеете ли вы навыками онлайн-преподавания?»

Вне зависимости от региона и территории «город - село» подавляющее большинство респондентов (90\%) используют в учебном процессе и для подготовки к урокам интернет-ресурсы (поиск информации, создание презентаций).

В блоке анкеты для анализа неравенства второго типа - владения цифровыми компетенциями мы предложили вопрос о наличии самостоятельно разработанных, персональных онлайн-ресурсов, таких как личные сайты, предметные блоки учебно-методических материалов и пр. Выявлены различия в паре «мегаполис - регионы» в сторону более высокого уровня цифровых компетенций в регионах (рис. 26). Так, 40\% петербургских респондентов утверждают, что имеют свои сайты или интернет-страницы, но некоторые региональные представители (Ямало-Ненецкий AO, Архангельская и Московская области) в этом плане гораздо более продвинуты больше половины из них имеют свое «личное интернет-пространство». При сравнении «мегаполис - регионы» по показателю, отражающему долю педагогов, занимающихся разработкой собственных учебно-методических комплектов (УМК), эта характеристика оказывается не в пользу мегаполиса. В среднем не более 24\% педагогов Санкт-Петербурга положительно ответили на этот вопрос, при этом у региональных респондентов почти всех регионов (кроме Алтайского края) доля положительных ответов превысила $30 \%$.

Относительно проблемных ситуаций по ответам респондентов внимание привлекают данные по Архангельской области, где «личное интернет-пространство» учителя представлено только сайтом учителя, при практически полном отсутствии онлайн-УМК. Значительное число отрицательных ответов получено также от респондентов Вологодской области. Неожиданно высокие показатели по использованию онлайн-УМК в школах Псковской области объясняются малой выборкой из этого региона и, соответственно, относительно высокой долей положительных ответов. 


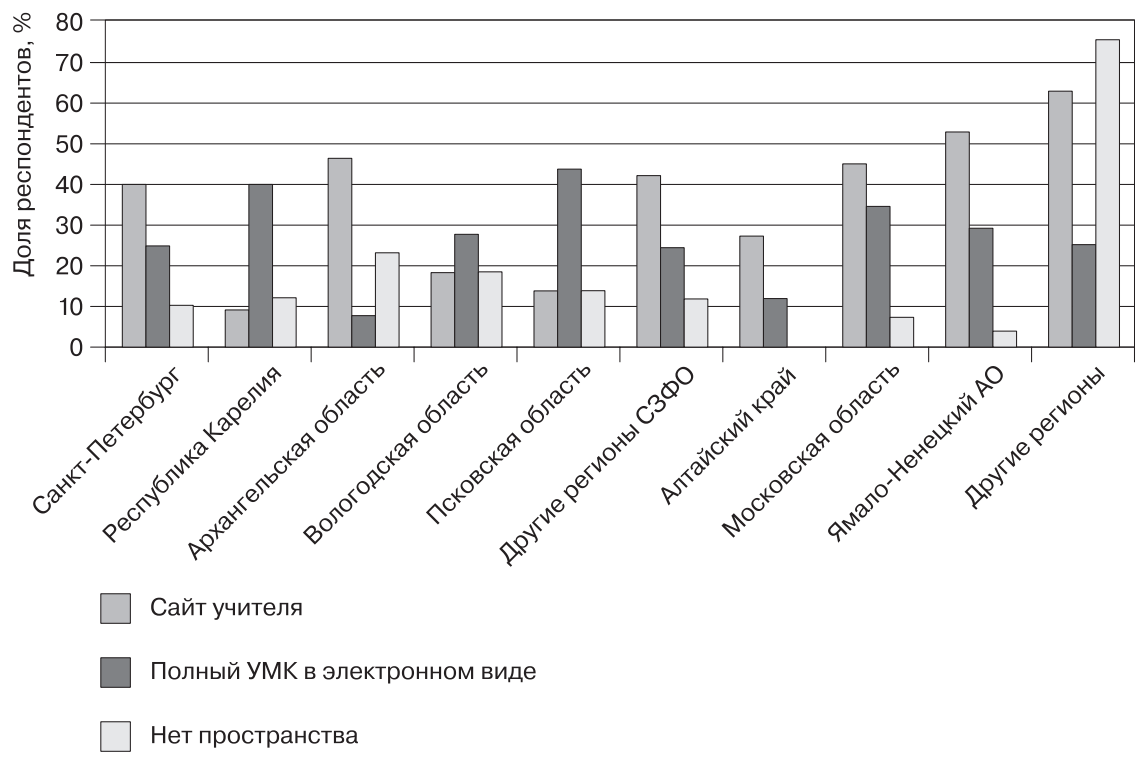

Puc. 26. Распределение ответов на вопрос «Есть ли у вас личное интернет-пространство?»

Анализ ответов по этому же показателю, но в возрастном разрезе, показал, что наиболее активны в плане использования электронных ресурсов учителя старшей возрастной группы (55 лет и старше): только 5\% ответили, что у них нет своего личного интернет-пространства (во всех остальных возрастных группах - 11-12\%), а наличие и использование электронных УМК и собственных авторских курсов подтвердили $33 \%$ учителей старше 55 лет, в то время как среди учителей от 26 до 45 лет эти позиции выбрали 29\%, в возрасте 46-55 лет - 22\%, а в возрасте 20-25 лет 18\% респондентов.

Ответы администраторов школ на этот вопрос показывают в среднем низкую активность в плане создания собственных ресурсов в Интернете. В большинстве регионов личную страницу на сайте школы имеют не более $25 \%$ представителей администрации, более высокое значение зафиксировано только для школ Санкт-Петербурга (42\%) и Алтайского края (67\%). В среднем 50\% респондентов-администраторов отметили, что представлены в сети собственным сайтом (причем доля администраторов из Санкт-Петербурга по этому показателю составляет всего 37\%).

Если говорить об активности административного состава в части разработки собственных учебных материалов для использования в учебном процессе, то здесь показатели еще менее позитивные (рис. 27). На общем фоне можно выделить только результаты по Республике Карелия и относительно высокий показатель по разработанным УМК в Псковской области. В то же время стоит отметить, что администраторы школ нескольких регионов выбрали вариант «Авторские дистанционные курсы», полностью отсутствовавший в ответах преподавателей (в том числе Санкт-Петербург - 10\%, Республика Карелия - более 20\%). Администраторы Архангельской и Московской областей собственных УМК и авторских курсов не имеют. 


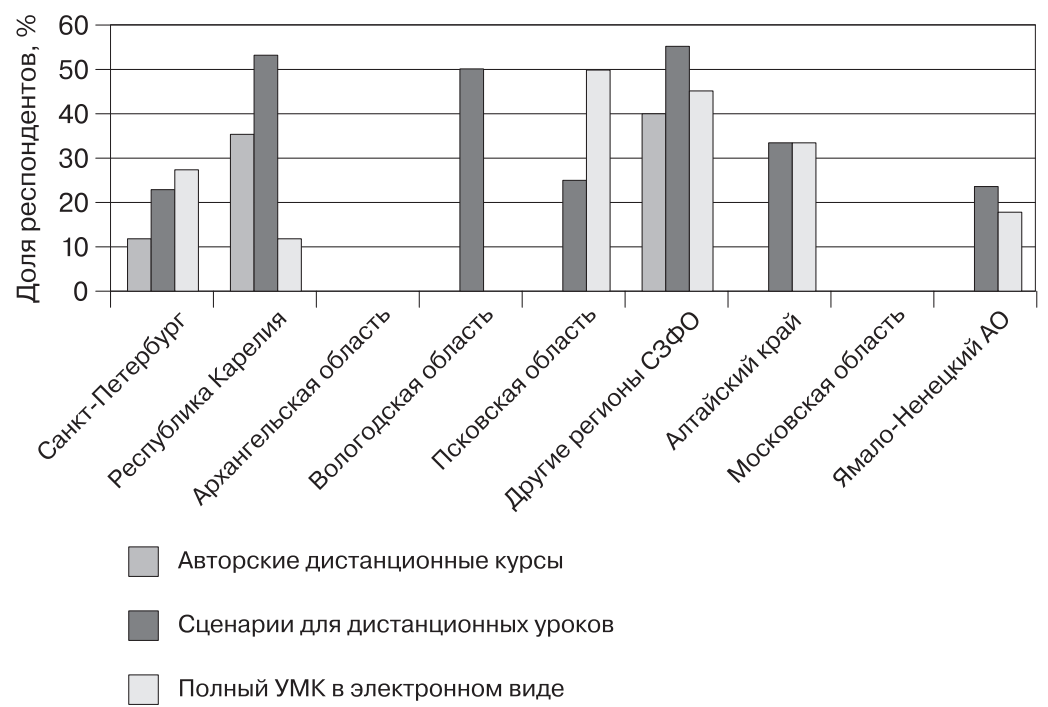

Puc. 27. Распределение ответов представителей администрации школ на вопрос «Есть ли у вас личное интернет-пространство?»

Вполне оптимистично выглядят ответы респондентов на вопрос, связанный с самооценкой собственной компетентности в плане освоения цифровых технологий. В разрезе регионов большинство педагогов и администраторов выбрали вариант самооценки «Хороший уровень, что-то еще не удается, но я легко обучаюсь». Наиболее низко оценивают свой уровень цифровой компетенции педагоги Вологодской и Псковской областей, а также представители Алтайского края (вариант «Ниже среднего уровня, все еще прохожу обучение и испытываю трудности»). В разрезе «город - село» 31\% учителей сельских школ выбрали вариант «Средний уровень», а 12\% - вариант «Ниже среднего»; только 4\% сельских педагогов оценили свой уровень как «Продвинутый пользователь» (рис. 28). В возрастном разрезе в среднем по регионам 60\% респондентов до 55 лет выбрали вариант «Хороший уровень» (после 55 лет положительный ответ на этот вопрос дал каждый второй респондент); вариант «Продвинутый пользователь» отметили $35 \%$ учителей до 30 лет и только 9\% учителей старше 46 лет. Стоит также отметить, что 1\% учителей старше 35 лет выбрали вариант «Низкий уровень, но не вижу необходимости повышать его».

Обобщая все вышесказанное, можно выделить следующее.

Наше первоначальное умозаключение состояло в том, что мы обнаружим признаки цифрового неравенства общеобразовательных школ, расположенных в крупном мегаполисе (Санкт-Петербург) и в разных регионах России, по двум основаниям: 1) технологическое неравенство школ (наличие/отсутствие технических средств обучения) и 2) компетентностное неравенство педагогов (наличие/отсутствие цифровых навыков у учителей и представителей администрации).

Анализ полученных материалов позволил выделить по пять показателей в каждом из двух оснований, которые дают возможность отразить комплексное представление респондентов о различных аспектах возможного цифрового неравенства общеобразовательных школ Санкт-Петербурга и российских регионов. 


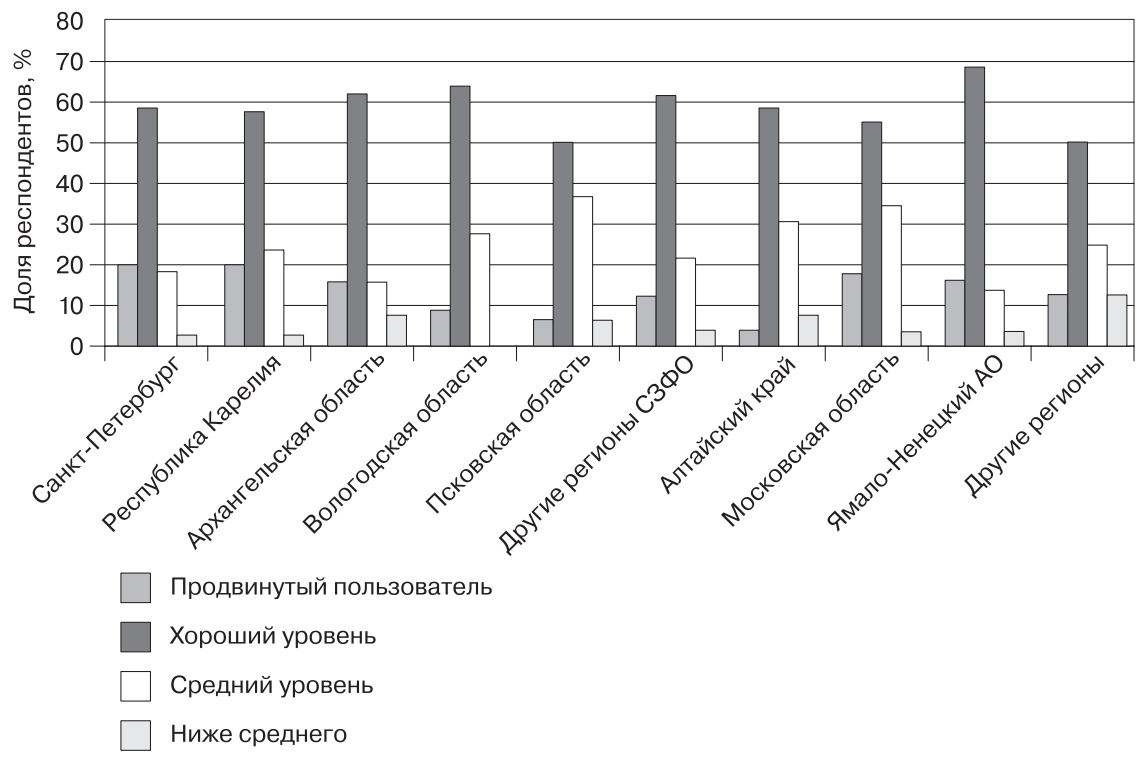

Рис. 28. Распределение ответов респондентов на вопрос «Оцените свой уровень пользователя в цифровом пространстве»

Среди показателей, характеризующих технологическое неравенство школ, наиболее существенны следующие:

1) отсутствие/наличие в школе стационарных компьютерных классов и стационарного компьютера преподавателя в классе;

2) отсутствие/наличие передвижных (мобильных) компьютерных классов;

3) отсутствие/наличие стационарного компьютера в учительской или ноутбука для учителя;

4) отсутствие/наличие доступа к Интернету (проводной, Wi-Fi) и возможности его использования в учебных классах и других помещениях школы;

5) возможность свободного использования Интернета на территории школы.

Выделены пять показателей компетентностного неравенства у представителей администрации и педагогов общеобразовательных школ Санкт-Петербурга и российских регионов:

1) уровень использования интернет-ресурсов для подготовки к урокам;

2) участие/неучастие в сетевых профессиональных сообществах;

3) уровень владения навыками онлайн-преподавания;

4) отсутствие/наличие личного интернет-пространства, включая разработку собственных цифровых образовательных ресурсов;

5) самооценка педагогов и администраторов образовательных учреждений по их собственной готовности к работе в цифровой образовательной среде.

На основе анализа результатов опроса представителей администрации по пяти показателям нет оснований утверждать, что школы Санкт-Петербурга имеют значительные преимущества в технической оснащенности образовательного и административного процессов перед школами российских регионов:

- не выявлено преимуществ мегаполиса (Санкт-Петербург) перед другими регионами по показателю оснащенности стационарными компью- 
терными кабинетами: практически в 100\% общеобразовательных школ и Санкт-Петербурга, и других регионов выборки есть в наличии не менее одного компьютерного класса и рабочего места учителя, оснащенного компьютером;

- выявлено неравенство общеобразовательных школ по показателю наличия/отсутствия передвижных (мобильных) компьютерных классов. В школах Санкт-Петербурга 63\% положительных ответов респондентов, что существенно ниже, чем в таких регионах, как Вологодская область (75\%), Алтайский край (100\%) и Ямало-Ненецкий АО (76\%). Наиболее низкий уровень оснащенности мобильными классами (25\%) в школах Псковской области, а в Архангельской области отмечено полное отсутствие мобильных классов;

- наличие в помещении учительской стационарных компьютеров отметили 60\% респондентов из Санкт-Петербурга. По этому показателю было выявлено явное цифровое неравенство в таких регионах, как Республика Карелия и Ямало-Ненецкий АО (по 41\%), а также в Псковской области (0\%);

- выявлен межрегиональный разброс ответов респондентов по показателю оснащенности учителей ноутбуками: от 82\% в Ямало-Ненецком АО до 47\% в Республике Карелия;

- большой разрыв в рамках технологического неравенства отмечают респонденты по показателю «наличие проводного Интернета (выделенной линии)»: от 85\% в Архангельской области до 40\% в Вологодской;

- в представлениях школьных администраторов наличие бесплатного $\mathrm{Wi-Fi} \mathrm{«колеблется»} \mathrm{от} \mathrm{13 \%} \mathrm{в} \mathrm{Республике} \mathrm{Карелия} \mathrm{до} \mathrm{30 \%} \mathrm{в} \mathrm{школах} \mathrm{Во-}$ логодской и Московской областей и Ямало-Ненецком АО.

Второй тип неравенства - компетентностное неравенство в представлениях администрации и педагогов общеобразовательных школ имеет следующие разрывы:

- интернет-ресурсами для подготовки к урокам пользуются более 90\% педагогов (по всем регионам выборки). Видеозаписи готовых уроков (второй по частоте упоминания вариант ответа) в среднем используют порядка 22-23\% респондентов (Санкт-Петербург). Разброс долей положительных ответов респондентов составляет от 37\% (Вологодская и Псковская области) до 15\% (Республика Карелия и Архангельская область);

- по показателю использования потенциала сетевых профессиональных сообществ в среднем по выборке более $30 \%$ педагогов ответили, что не участвуют в таких сообществах (среди педагогов младше 26 лет - 72\%);

- оценка учителями общеобразовательных школ собственных навыков владения онлайн-технологиями преподавания учебного предмета показала, что в среднем эти навыки сформированы и применяются на практике у 40\% педагогов (в Республике Карелия положительный ответ дали более $70 \%$ респондентов). Не владеет данными навыками каждый третий респондент Псковской области и Алтайского края (при среднем уровне 10\% по всем остальным регионам).

По данному показателю выявлено существенное неравенство в разрезе «город - село»: более $40 \%$ респондентов сельских школ не владеют навыками онлайн-преподавания в сравнении с $10 \%$ городских респондентов, а также в возрастном разрезе: учителя старше 
35-40 лет выбирали ответ «Нет, не владею» вдвое чаще, чем учителя младше 30 лет (12 и 6\% соответственно);

- каждый четвертый респондент (24\%) Санкт-Петербурга утверждает, что разрабатывает собственные электронные учебно-методические комплекты, в то время как в большинстве других регионов положительный ответ на этот вопрос давал каждый третий респондент (более $30 \%$ ). В возрастном разрезе этот показатель имеет нисходящую тенденцию от учителей старшего возраста (старше 55 лет - 33\% положительных ответов) к более молодым педагогам (20-25 лет - 18\%);

- самооценка собственной цифровой компетенции у представителей педагогического состава мегаполиса как «продвинутый пользователь» выше, чем в других регионах (положительный ответ по этому показателю зафиксирован у 20\% респондентов Санкт-Петербурга и 15-16\% у большинства педагогов из регионов). Минимальные показатели самооценки цифровой компетенции (менее 10\%) отмечены у педагогов из школ Алтайского края, Вологодской и Псковской областей. Выявлена низкая самооценка цифровой компетентности у учителей и администраторов сельских школ и у учителей старше 50-55 лет. В то же время в среднем $60 \%$ администраторов из всех регионов оценили свой уровень подготовки как хороший.

Подводя итоги, можно сделать следующие выводы:

1) по возможному технологическому неравенству общеобразовательных школ результаты опроса администрации и учителей не выявили явного преимущества мегаполиса (Санкт-Петербург) над другими российскими регионами. По четырем показателям из пяти как минимум в одном-двух регионах отмечен более высокий уровень технологической оснащенности общеобразовательных школ. Среди российских регионов самые низкие результаты (по четырем из пяти показателей) зафиксированы в Псковской области;

2) по возможному компетентностному неравенству можно отметить в целом невысокий уровень участия педагогов, в том числе жителей мегаполиса, в сетевых профессиональных сообществах, а также среднюю оценку педагогами собственной готовности к работе в цифровой образовательной среде. Наибольший разброс показателей между регионами выявлен по показателям самооценки собственной цифровой компетенции и владения навыками онлайн-преподавания;

3) в возрастном разрезе отмечается более высокий уровень создания и использования электронных УМК и собственных авторских курсов среди учителей старше 55 лет (33\%) по сравнению с молодыми коллегами (18-29\%). В то же время учителя старшей возрастной категории (после 46 лет) невысоко оценили собственный уровень компетенции по владению компьютерными технологиями, включая средства онлайн-образования (дистанционного). Можно предположить, что опытные учителя в большей степени овладели методиками использования цифровых учебных материалов (в том числе УМК) для работы с учениками. В то же время они критически оценивают свою готовность перенести учебный процесс в цифровые форматы (включая онлайнобучение). А более молодое поколение, не испытывая сложностей в овладении дистанционными технологиями, не имеет достаточного 
опыта в адаптации методического обеспечения к условиям работы в цифровой образовательной среде.

Оценивая готовность школ к цифровой трансформации, можно заключить, что полученная информационная картина не дает оснований для однозначных заключений о состоянии образовательных учреждений по формальным показателям (принадлежность к региону, образовательный уровень, активность в профессиональных сообществах, педагогический стаж и др.). В рамках дополнительного телефонного опроса большинство руководителей образовательных учреждений выказали заинтересованность во внедрении цифровых технологий в регулярный учебный процесс, но отмечали при этом отсутствие разработанных методик, дидактических материалов и апробированных проектных решений для более быстрого и эффективного их внедрения.

Следует также отметить, что одной из актуальных задач управления образованием является выбор оптимального масштаба кластеров, в которых должны реализовываться модернизационные процессы. Результаты исследования наводят на мысль, что отдельной школе сложно самостоятельно решить проблему перехода к цифровым отношениям в педагогическом и (особенно) управленческом аспектах. С другой стороны, унифицированные решения, принимаемые на уровне федеральных или региональных систем управления образованием, не могут в полной мере учесть различия стартовых условий. С точки зрения управления необходимо определить оптимальный размер кластера, для которого может быть разработана и внедрена модель управляемого процесса цифровизации - с учетом специфики региона, социального контекста, в которых находятся образовательные организации, и других факторов, значимость которых для цифровой трансформации еще только предстоит исследовать.

\section{Литература}

1. Абрамова М. А., Фарника М. Цифровизация образования в условиях цифрового неравенства // Профессиональное образование в современном мире. 2019. Т. 9. № 4. С. 3167-3175.

2. Адамович К. А. Учащиеся начальных классов и их педагоги в цифровой среде / К. А. Адамович, А. В. Капуза, А. А. Горбунова // Национальный исследовательский университет «Высшая школа экономики», Институт образования. М. : НИУ ВШЭ, 2020.

3. Архипова М. Ю. Разработка композитного индикатора для измерения величины и динамики цифрового неравенства в России / М. Ю. Архипова, В. П. Сиротин, Н. А. Сухарева // Вопросы статистики. 2018. T. 25. № 4. С. 75-87 [Электронный ресурc]. URL: https://voprstat.elpub.ru/jour/article/ view/667?locale=ru_RU (дата обращения: 12.07.2021).

4. Беликов А. А. Анализ спроса на педагогов в области цифровых технологий / А. А. Беликов, Е. Е. Хабирова, М. А. Клубова, В. А. Игнатова // Мониторинг экономики образования. Национальный исследовательский университет «Высшая школа экономики». 2021. № 6.

5. Блинов В. И. Проект дидактической концепции цифрового профессионального образования и обучения / В. И. Блинов, М. В. Дулинов, Е. Ю. Есенина, И. С. Сергеев. М. : Перо, 2019. 72 с.

6. Брагина Е. М., Орлова Д. С. Преодоление цифрового неравенства в условиях Крайнего Севера (на примере Ханты-Мансийского автономного округа — Югры) // Региональная экономика и управление : электронный научный журнал. 2017. № 3(51). С. 7 [Электронный ресурс]. URL: https://eee-region.ru/article/5107/ (дата обращения: 12.07.2021).

7. Буданцев Д. В. Цифровизация в сфере образования: обзор российских научных публикаций // Молодой ученый. 2020. № 27(317). 
8. Волченко О. В. Динамика цифрового неравенства в России // Мониторинг общественного мнения: экономические и социальные перемены. 2016. № 5. С. 163-182. Dol: https://doi.org/10.14515/ monitoring.2016.5.10

9. Гайнанов Д. А., Шарифьянов Т. Ф. Трансформация модели преодоления цифрового неравенства в сельской местности //Управление экономическими системами : электронный научный журнал. 2015. № 12(84). С. 24 [Электронный ресурc]. URL: https://elibrary.ru/item.asp?id=25622289 (дата обращения: 12.07.2021).

10. Гладкова А. А. Модель трех уровней цифрового неравенства: современные возможности и ограничения (на примере исследования Республики Татарстан) / А. А. Гладкова, В. З. Гарифуллин, М. Рагнедда // Вестн. Моск. ун-та. Сер. 10. Журналистика. 2019. № 4.

11. Добрякова М. С. Образовательное неравенство в период дистанционного обучения: феноменологический взгляд / М. С. Добрякова, Е. В. Сивак, О. В. Юрченко // НИУ «Высшая школа экономики». 2021. № 11.

12. Дронов В. Н., Махрова О. Н. Цифровое неравенство Рязанской области : монография // СанктПетербургский ун-т управления и экономики, Ин-т социально-экономических проблем народонаселения РАН. СПб. : Изд-во Санкт-Петербургского университета управления и экономики, 2015. 148 с.; ил.

13. Дятлов С. А., Селищева Т. А. Регионально-пространственные характеристики и пути преодоления цифрового неравенства в России // Экономика образования. 2014. № 2. С. 48-52 [Электронный pecypc]. URL: https://elibrary.ru/item.asp?id=21820670 (дата обращения: 12.07.2021).

14. Индекс готовности регионов России к информационному обществу 2013-2014. Анализ информационного неравенства субъектов Российской Федерации / под ред. Т. В. Ершовой, Ю. Е. Хохлова, С. Б. Шапошника. М., 2015.524 с.

15. Ициксон А. И. Устранение цифрового неравенства // Вестник Южно-Уральского государственного университета. Сер.: Экономика и менеджмент. 2017. Т. 11. № 4. С. 156-164. DOI: https://doi. org/10.14529/em170421

16. Капуза А. В. Учащиеся начальных классов и их педагоги в цифровой среде / А. В. Капуза, А. А. Горбунова, К. А. Адамович // Национальный исследовательский университет «Высшая школа экономики», Институт образования. М. : НИУ ВШЭ, 2020. 32 с. (Факты образования. № 5(30)).

17. Кузнецов Ю. А., Маркова С. Е. Некоторые аспекты количественной оценки уровня цифрового неравенства регионов Российской Федерации // Экономический анализ: теория и практика. 2014. № 32(383). С. 2-13 [Электронный ресурc]. URL: https://www.fin-izdat.ru/journal/analiz/detail. php?ID=63090 (дата обращения: 12.07.2021).

18. Лебедев О. Е. Качество образования: критерии оценки // Управление качеством образования: теория и практика эффективного администрирования. СПб. : Эффектико Групп, № 2, 2020а.

19. Лебедев О.Е. Отношения в системе образования: возможности управления // Человек и образование. 20206. № 3(64).

20. Лысенко Э. А., Федосеева С. В. На пути становления информационного общества: ликвидация цифрового неравенства среди граждан старшего поколения // Информационное общество. 2014. № 1. С. 11-16 [Электронный ресурс]. URL: http://emag.iis.ru/arc/infosoc/emag.nsf/BPA/2ef9e67ce1 92d2c044257сас00442248 (дата обращения: 12.07.2021).

21. Мальсагова К. Б. Информационно-цифровое неравенство в современном российском обществе // Научные записки молодых исследователей. 2016. № 4-5.

22. Мамаева О. Б. «Цифровое неравенство» как новый критерий социальной стратификации в условиях доступа к государственным электронным услугам // Социальная сфера, экономика и управление: вопросы теории и практики : сб. ст. Йошкар-0ла, 2017. С. 65-72.

23. Материалы международного семинара «Проблемы преодоления „цифрового неравенства“ в России и странах СНГ». МоскВа, Дом Правительства РФ, 28 ноября 2000 г. [Электронный ресурс]. URL: https://rudocs.exdat.com/docs/index-224528.html (дата 0бращения: 12.07.2021). 
24. Перфильева О. В. Проблема цифрового разрыва и международные инициативы по ее преодолению // Вестник международных организаций. 2007. № 2(10).

25. Санникова Т. Д. Цифровое неравенство как негативный фактор для благополучия сельского населения // Вестник науки. 2018. T. 1. №6(6). С. 21-27 [Электронный ресурc]. URL: https://вестникнауки.рф/archiv/journal-6-6-1.pdf (дата обращения: 12.07.2021).

26. Сапрыкина Д. И., Волохович А. А. Проблемы перехода на дистанционное обучение в Российской Федерации глазами учителей // Национальный исследовательский университет «Высшая школа экономики», Институт образования. М. : НИУ ВШЭ, 2020.

27. Сафиуллин А. Р., Моисеева О. А. Цифровое неравенство: Россия и страны мира в условиях четвертой промышленной революции // Научно-технические ведомости СПбГПУ. Экономические науки. 2019. T. 12. № 6.

28. Уваров А. Ю. Трудности и перспективы цифровой трансформации образования / Э. Гейбл, И. В. Дворецкая [и др.] ; под ред. А. Ю. Уварова, И. Д. Фрумина ; Нац. исслед. ун-т «Высшая школа экономики», Ин-т образования. М. : Изд. дом Высшей школы экономики, 2019.

29. ХимичукЕ. В. Цифровое неравенство или неравенство в цифрах // Политика и Общество. 2018. Т. 1 [Электронный ресурс]. URL: cyberleninka.ru/article/n/tsifrovoe-neravenstvo-ili-neravenstvo-v-tsifrah (дата обращения: 21.06.2021).

30. Шамсутдинова Т. М. Роль и место образования в преодолении цифрового неравенства (по материалам Республики Башкортостан) // Регионология. 2019. Т. 27. № 2.

31. Шолохов А. В. Информационные аспекты образовательного неравенства // Известия ТРТУ. Тематический выпуск. Раздел ІІ. Исследование и моделирование экономических систем. 2007. № 2. C. 33-36.

32. A Nation Online: How Americans Are Expanding Their Use of The Internet // NTIA. September 2002 [Электронный ресурс]. URL: https:// www.ntia.doc.gov/legacy/ntiahome/dn/html/anationonline2. $\mathrm{htm}$ (date of access: 12.07.2021).

33. Falling Through the Net II: New Data on the Digital Divide // NTIA. July 1998 [Электронный ресурс]. URL: https://www.ntia.doc.gov/report/1998/falling-through-net-ii-new-data-digital-divide (date of access: 12.07.2021).

34. Falling Through the Net: Defining the Digital Divide // NTIA. November 1999 [Электронный ресурс]. URL: https://www.ntia.doc.gov/legacy/ntiahome/fttn99/contents.html (date of access: 12.07.2021).

35. Falling Through the Net: Toward Digital Inclusion // NTIA. October 2000 [Электронный ресурс]. URL: https://www.ntia.doc.gov/ report/2000/falling-through-net-toward-digital-inclusion (date of access: 12.07.2021).

36. Hargittai E. Second-Level Digital Divide: Mapping Differences in People's Online Skills // Cornell University. 2001 [Электронный ресурс]. URL: https://arxiv.org/ftp/cs/papers/0109/0109068.pdf (date of access: 12.07.2021). 


\section{ГЛАВА 7}

\section{Цифровые дети и нецифровые родители}

В научном поле изучение вопросов семейного воспитания, детско-родительских и семейных отношений довольно обширно [Александрова; Александрова, Костина; Коробкова; Хоменко 2012, 2013], но большая их часть относится к так называемому аналоговому, а не цифровому миру.

В контексте исследования разных аспектов цифровой среды внимание ученых привлекают разные проблемы детей: информационная безопасность [Будыкин], увлечение детей гаджетами [Барсукова], формирование интернетзависимости [Малыгин].

В России широкомасштабные исследования человека в цифровой среде в последние 10-15 лет проводятся регулярно ${ }^{37}$ («Интернет глазами школьника», 2007-2008; «Моя безопасная сеть», 2007; «Дети России онлайн», 2010; «Исследование цифровой компетентности российских школьников и родителей» $\left.{ }^{38}, 2020\right)$, однако их фокус направлен преимущественно на изучение цифровой компетентности детей, родителей и педагогов, а не на особенности их взаимодействия в цифровую эпоху. Но именно характер взаимодействия определяет уровень конфликтогенности образовательной среды и влияет на достижение личностных результатов.

Зарубежные ученые пытаются рассмотреть проблему глубже и выходят на исследование психологических и психофизиологических аспектов развития детей и взрослых в информационной среде [Neufeld; Turkle; Hафиса, Алиджон]. Широко изучаются вопросы влияния родителей на становление и развитие современных детей: уровень образования родителей [Harding], влияние ИКТ-знаний родителей на уровень взаимодействия с детьми в образовательном процессе [Нафиса, Алиджон], влияние родительской критики на агрессивность детей [Frazer], влияние материнского поведенческого контроля на поведение детей [Dong], также изучается роль родительского тепла и враждебности в просоциальном поведении подростков [Padilla-Walker]. B работе [Gunderson] изучается влияние родительских похвал и критики на развитие детского интеллекта и учебных целей. Отметим, что ученые пытаются изучать и эффективность программы поддержки семьи [Amorós-Martí]. В последние годы возрос интерес ученых к исследованию родительских аттитюдов в отношении общения детей с виртуальной средой ([Dardanou; Dias] и др.). Более подробный обзор подобных исследований содержится в статье [Писаренко, Заиченко].

37 Фонд Развития Интернет [Электронный ресурc]. URL: http://www.fid.su/projects/research (дата обращения 16.07.2021).

38 Исследование особенностей цифровой социализации разных поколений в рамках проекта РНФ № 18-18-00365 «Цифровая социализация в культурно-исторической перспективе: внутрипоколенческий и межпоколенческий анализ» (руководитель Г.В.Солдатова). 
Можно констатировать, что семья имеет большое значение в образовательном процессе современного ребенка, однако наука пока не дает достаточно полного ответа на вопрос, какие именно родительские и учительские педагогические стратегии, а также представления о новом цифровом мире могут помочь развитию «цифровых» детей.

С целью восполнения этого дефицита в 2020 г. в рамках работы по гранту РФФИ № 19-29-14060 «Управление развитием образовательных отношений субъектов начальной школы в условиях цифровизации» нами было проведено исследование, посвященное изучению позиции родителей учеников начальной школы в отношении перехода на цифровизацию образовательного процесса. Основными задачами исследования было выявление запросов родителей на развитие у детей цифровых навыков, а также изучение «цифровых барьеров» родителей (то есть их опасений и предубеждений против цифровизации) и того «цифрового контекста», в котором они находятся (уровень цифровой компетентности, используемые гаджеты и цифровые инструменты).

Отдельно стояла задача изучения представлений родителей о том, как цифровизация может сказаться на отношениях всех пар субъектов образовательного процесса (детей и родителей, учеников и учителей, детей и сверстников, педагогов и родителей, родителей между собой).

Отметим, что идея опроса состояла не в том, чтобы понять, «как думает большинство», а в том, чтобы увидеть спектр родительских мнений, «поймать» тренды, складывающиеся в родительской среде, и, возможно, выявить определенные типы родителей.

Внимание автора сфокусировано на описании своеобразных «портретов» современных родителей в контексте их отношения к цифровизации.

\section{1. Материалы и методы}

Основным методом исследования было анонимное анкетирование с помощью традиционных бумажных анкет, содержащих 15 вопросов открытого и закрытого типа. Открытые вопросы касались проблем, которые возникают у родителей в связи с цифровизацией образовательного процесса, а также позитивных/негативных ожиданий от ее реализации в перспективе.

Данный метод был выбран в связи с тем, что позволял участвовать в опросе даже тем респондентам, которые не владеют информационными технологиями. К тому же он был привычен для родителей школьников.

Прочедура анкетирования включала два этапа: подготовительный и основной.

На подготовительном этапе происходила апробация разработанного диагностического инструмента, после которой вопросы были откорректированы для лучшего понимания их респондентами и сгруппированы в таблицы для оптимизации объема текста.

На основном этапе в анкетировании участвовало 118 родителей в возрасте от 29 до 61 года, дети которых посещали одну начальную школу. Гендерный и возрастной факторы респондентов не учитывались как значимые.

Опрос проходил в период с 10 по 25 февраля 2020 г. путем раздачи родителям анкет на родительском собрании и последующего сбора анкет в произвольном порядке. Поскольку большинство родителей или членов семьи 
встречают учеников начальной школы после уроков, сбор анкет происходил в момент прихода родителей в школу в один из дней данного периода.

При обработке полученных данных применялся количественный и качественный анализ.

Существенным моментом этого опроса является то, что он проводился в период до наступления пандемии коронавируса и самоизоляции, поэтому позиции родителей были зафиксированы на момент протекания обычной школьной жизни и отражают те страхи, барьеры и ожидания, которые существовали у них в ситуации фрагментарного знакомства с цифровыми инструментами и процессами.

\section{2. Как родители понимают цифровизацию}

Отношение к новому явлению формируется в том числе и по тому, как именно оно «расшифровывается» пользователем. Поэтому первый вопрос, заданный родителям, был именно об этом: «Что вы понимаете под цифровизацией школы?»

В ответах на этот вопрос респондентам предлагалось выбрать не более трех вариантов из списка либо дописать свой вариант.

Основная масса родителей (89\%) выбрали от 1 до 3 вариантов готовых ответов (рис. 29). Эти варианты можно распределить по трем группам:

1) техническое оснащение (варианты а и с, в совокупности около 84\%);

2) способ деятельности (варианты $b, d$, е и $f$, в совокупности около 102\%);

3) новый формат отношений (вариант $g$, около 17\%).

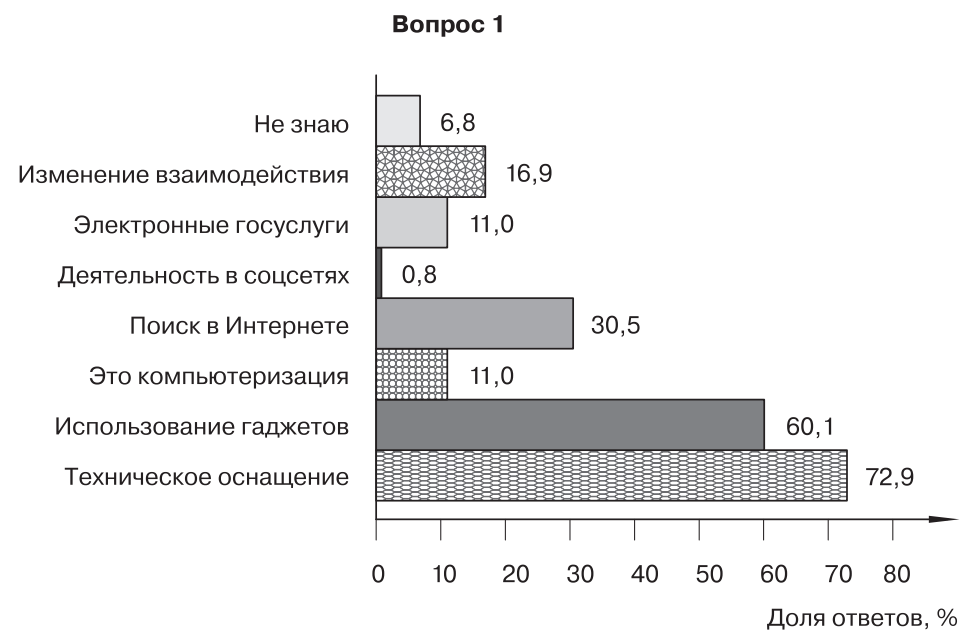

Puc. 29. Понимание термина «цифровизация» родителями учеников начальной школы

Часть родителей (около 7\%) затруднились с ответом, так как у них «не было необходимости думать о том, что такое цифровизация». В одной из анкет, отвечая в дальнейшем на вопрос об опасениях, респондент ответил: «Это будет нескоро».

Примечательно, что подавляющее большинство таких ответов дали родители, имеющие двух и более детей и высказывающие в последующих ответах 
негативные прогнозы относительно цифровизации. По всей видимости, у таких родителей наблюдается интуитивно-негативное отношение к новому для них явлению, и они пока не выработали четкой позиции по многим аспектам данной темы. Это подтверждают и их ответы на последующие вопросы, связанные с решением возможных проблем: более половины «незадумывающихся» родителей не выбрали ни одного варианта из предложенных.

В табл. 10 приведены конкретные формулировки предлагаемых респондентам ответов.

Таблица 10

Распределение ответов родителей начальной школы на вопрос о понимании термина «цифровизация»

\begin{tabular}{|c|l|c|}
\hline Bариант & \multicolumn{1}{|c|}{ Содержание ответа } & $\begin{array}{c}\text { Доля выбравших } \\
\text { данный вариант от- } \\
\text { вета от общего числа } \\
\text { опрошенных, \% }\end{array}$ \\
\hline$a$ & Прежде всего это техническое оснащение школ компьютерной техникой & 72,9 \\
\hline$b$ & Использование учителями на уроках разных гаджетов, презентаций & 60,1 \\
\hline$c$ & $\begin{array}{l}\text { Я не делаю различий между информатизацией и цифровизацией, } \\
\text { компьютеризацией — все одно и то же, просто слова разные }\end{array}$ & 11,0 \\
\hline$d$ & $\begin{array}{l}\text { Это работа учеников и учителей сразличными поисковыми системами } \\
\text { в Интернете (для поиска информации, музыки, фото, видео) }\end{array}$ & 30,5 \\
\hline$e$ & $\begin{array}{l}\text { Это разные активные действия родителей, учителей, учеников } \\
\text { в социальных сетях }\end{array}$ & 0,8 \\
\hline$f$ & $\begin{array}{l}\text { Это возможности использования электронных государственных услуг } \\
\text { через Интернет }\end{array}$ & 11,0 \\
\hline$g$ & $\begin{array}{l}\text { Это изменение поведения и различныхвзаимодействий между участниками } \\
\text { образовательных отношений (родители, учителя, школьники) }\end{array}$ & 16,9 \\
\hline$h$ & Не знаю, не было необходимости думать о том, что такое цифровизация & 6,8 \\
\hline$i$ & Другое & 11,0 \\
\hline
\end{tabular}

Свой вариант предпочли дописать около 11\% родителей.

Приведем примеры этих формулировок (здесь и далее орфография и пунктуация респондентов сохранены, за исключением случаев, затрудняющих понимание смысла написанного).

Некоторые респонденты под цифровизацией понимают «электронное/ дистанционное обучение»:

- «это работа учеников и учителей с разными устройствами (ПК, смартфон, проектор и т. д.) и программным обеспечением для усвоения учебного материала»;

- «это возможность получать образование, в том числе и удаленно, сдавать экзамены, контрольные».

Кто-то считает цифровизацией разные способы связи: «использование информации в цифровом виде через компьютер», «переход на цифровой способ связи, запись и передача данных с помощью цифровых устройств».

Две анкеты содержали негативные прогнозы:

- «1) развитие онлайн-обучения под предлогом внедрения новых прогрессивных технологий; 2) потеря традиционных методик обучения» (39 лет, один ребенок); 
- «цифровизация в моем понимании - это как онлайн-обучение, я против такого метода. Более придерживаюсь традиционной системы обучения» (35 лет, двое детей). Весьма примечательно, что данный респондент (в ответе на другой вопрос анкеты) не смог выделить никаких собственных педагогических проблем, связанных с цифровизацией, однако в целом обеспокоен проблемой «интернет-зависимости». Это можно объяснить тем, что страх данного родителя перед цифровизацией возник на основе не собственного опыта, а каких-то других источников.

Один из респондентов недоумевал: «Непонятно, о чем речь, отсутствует устойчивое смысловое наполнение слова „цифровизация"» (37 лет).

Таким образом, можно констатировать разнообразие трактовок родителями учеников начальной школы термина «цифровизация», среди которых доминирует представление, что это техническое оснащение, используемое в социальной и образовательной деятельности. Ни один респондент, отвечая на этот вопрос, не связал цифровизацию с цифровыми образовательными платформами, хотя в последующих ответах единичные анкеты содержали это слово/инструмент.

В контексте нашего исследования получен важный вывод: значительная часть родителей не понимают, что такое цифровизачия, а представление о том, что цифровизация предполагает иные роли и отношения между участниками образовательного процесса, смену ролей и зон ответственности субъектов, у большинства родителей учеников начальной школы $(74,1 \%)$ пока не сформировано.

\section{3. Как родители оценивают свой уровень цифровой компетентности}

Вопрос об этом задавался родителям с целью определить степень их включенности в цифровую среду, знакомства с ней и уровень использования ими цифровых средств.

Как известно, негативные ожидания, опасения у людей часто связаны с тем, что они плохо представляют себе новый (незнакомый) объект, а потому склонны в большей степени дистанцироваться от него и драматизировать ситуацию. Соответственно, определив уровень так называемой «цифровой компетентности» родителей, основанный исключительно на самооценивании респондентов (как они сами «чувствуют себя» в цифровой среде), можно будет понять, является ли ее повышение действенным способом снизить их тревожность и повысить уверенность в необходимости использования новых инструментов в образовании.

Отвечая на данный вопрос, некоторые респонденты, несмотря на инструкцию, выбирали больше одного ответа, поэтому суммарное количество долей немного превышает 100\% (табл. 11). Также при отражении данных намеренно не выделена позиция «Другое», так как лишь в одной анкете в варианте ответа е женщина написала: «Это лично мой уровень, и я не обязана его оглашать всем» (возраст не указан; анкета заполнена небрежно). Примечательно, что среди родителей учеников начальной школы не нашлось таких, кто не использует никакие цифровые средства (вариант ответа $d$ ), хотя возрастной диапазон участников опроса варьировался от 29 до 61 года. 
Распределение ответов респондентов об уровне их цифровой компетентности

\begin{tabular}{|c|l|c|}
\hline Вариант & \multicolumn{1}{|c|}{ Содержание ответа } & $\begin{array}{c}\text { Доля выбравших данный } \\
\text { вариант ответа от общего } \\
\text { числа опрошенных, \% }\end{array}$ \\
\hline$a$ & $\begin{array}{l}\text { Являюсь уверенным пользователем, разбираюсь в программиро- } \\
\text { вании, знаю законы, связанные с персональными данными }\end{array}$ & 16,9 \\
\hline$b$ & $\begin{array}{l}\text { Являюсь уверенным пользователем, но не разбираюсь в техниче- } \\
\text { ских вопросах }\end{array}$ & 61,9 \\
\hline$c$ & $\begin{array}{l}\text { Использую только некоторые сервисы, иногда прибегаю к помощи } \\
\text { более компетентных людей }\end{array}$ & 25,4 \\
\hline$d$ & Не использую никакие цифровые сервисы и средства & 0 \\
\hline$e$ & Ваш вариант: & \\
\hline
\end{tabular}

После обработки анкет все родители были условно разделены на три группы: «Профессионалы» (выбрали вариант ответа $a$ ), «Компетентные» (b), «Некомпетентные» (с) (рис. 30).

Некоторые респонденты отмечали по два варианта либо дописывали свой (например, «я IT-специалист»). Критерием отнесения родителя к той или иной группе служил более высокий уровень, заявленный респондентом.

Поскольку в рамках исследования предполагалась специальная работа с родителями учеников, дифференциация родителей по компетентностному признаку была принципиальной. Как показал дальнейший анализ ответов, уровень цифровой компетентности родителей связан с их позицией в отношении цифровизации (являются ли они ее сторонниками или противниками).

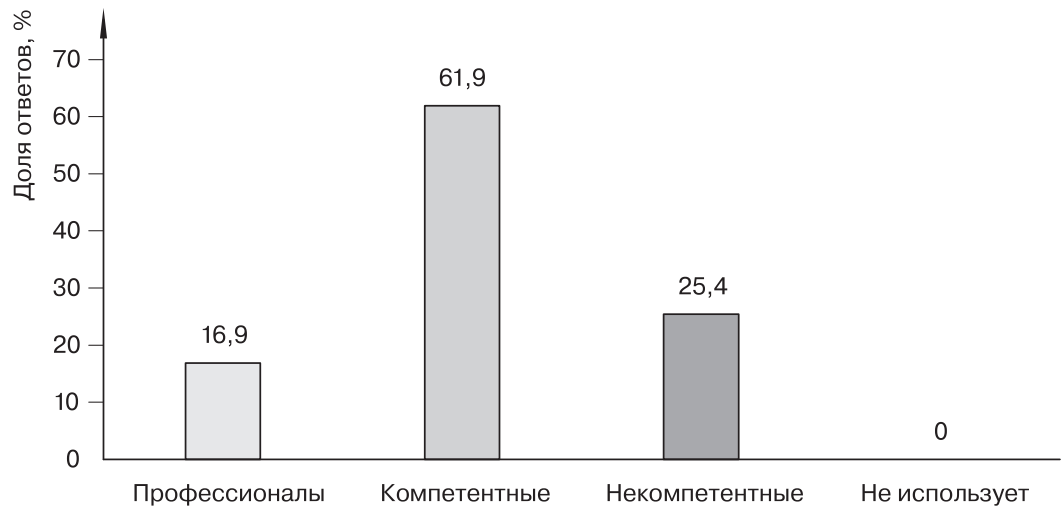

Puc. 30. Уровень цифровой компетентности родителей учеников начальной школы (на основе самооценивания)

Согласно полученным данным, основная масса родителей оценивают себя как уверенного пользователя (группа «Компетентные», более 60\%). Тем не менее довольно высокой для данного возраста (35-40 лет) является доля тех родителей, которые недостаточно активно и уверенно используют цифровые инструменты (группа «Некомпетентные», более четверти всех респондентов). Примерно $1 / 6$ часть позиционируют себя как профессиональных пользователей (группа с условным названием «Профессионалы», около 17\%). 
Это значит, что в родительском сообществе есть те, кто может стать своеобразным проводником и даже экспертом в процессе развития цифровых технологий в образовании.

\section{4. Сторонники и противники цифровизации - кто они?}

Для выявления позиций родителей по отношению к цифровизации были сформулированы два вопроса, заданных последовательно: «Какие опасения возникают у вас в связи с тем, что российские школы будут переходить на обучение с помощью цифровых технологий?» (вопрос № 10) и «Насколько эти опасения существенны лично для вас?» (вопрос № 11).

Два варианта ответа, предусмотренные в вопросе № 11, позволили разделить родителей на «противников» (вариант ответа $a$ ) и «сторонников» цифровизации (вариант ответа $b$ ), так как первый вариант обозначал соответствующуюпозицию максимально четко («...поэтомуя против цифровизации»).

При анализе ответов респондентов на данный вопрос учитывался и уровень их «цифровой компетентности». (Напомним, что выделение опрашиваемых по этому критерию осуществлялось на основе самооценивания родителями своего уровня компетентности в области цифровых технологий.)

Сводные данные с учетом выделенных групп представлены в табл. 12.

Таблича 12

Распределение респондентов по критерию сторонников и противников цифровизации

\begin{tabular}{|c|c|c|c|c|c|c|}
\hline \multirow{2}{*}{$\begin{array}{c}\text { Вари- } \\
\text { ант }\end{array}$} & \multirow{2}{*}{ Содержание ответа } & \multicolumn{2}{|c|}{ Bcero } & \multicolumn{3}{|c|}{$\begin{array}{c}\text { Доля выбравших данный вариант ответа } \\
\text { от общего числа опрошенных, \% }\end{array}$} \\
\hline & & Чел. & $\%$ & $\begin{array}{l}\text { Профессио- } \\
\text { налы }\end{array}$ & $\begin{array}{l}\text { Компетент- } \\
\text { ные }\end{array}$ & $\begin{array}{l}\text { Некомпетент- } \\
\text { ные }\end{array}$ \\
\hline$a$ & $\begin{array}{l}\text { Очень существенны, поэтому я } \\
\text { против введения цифровизации } \\
\text { в школе } \\
\text { («противник» цифровизации) }\end{array}$ & 29 & 24,6 & 21,1 & 28,4 & 18,7 \\
\hline$b$ & $\begin{array}{l}\text { Не очень существенны, так как } \\
\text { можно подумать о том, как } \\
\text { обезопасить детей от проблем, } \\
\text { связанных с цифровизацией } \\
\text { («сторонник» цифровизации) }\end{array}$ & 89 & 75,4 & 78,9 & 71,6 & 81,3 \\
\hline \multicolumn{2}{|l|}{ Итого } & 118 & 100 & 100 & 100 & 100 \\
\hline
\end{tabular}

Оказалось, что подавляющее большинство родителей $(75,4 \%)$ если и видят какие-то проблемы в связи с введением цифровых технологий в школе, то они не представляются им существенными (ответ $b$ ).

Среди остальных 24,6\% респондентов («противников» цифровизации) лишь незначительная часть настроены решительно: из 29 человек этой группы только в трех анкетах вариант ответа $a$ был отмечен дополнительными символами: в двух анкетах рядом стояли по три или четыре восклицательных знака, в одной - подчеркнуто слово «против». Все респонденты, активно обозначившие свою позицию, принадлежали к группе «Компетентные» - то есть родителей, которые являются уверенными пользователями, но не разбираются в технических вопросах. Среди «Профессионалов» и «Некомпетентных» 
наблюдалась более спокойная реакция, дополнительных комментариев или символов в ответах на данный вопрос не обнаружено.

Также был проведен анализ распределения родителей по уровню компетентности внутри групп «сторонников» и «противников» цифровизации (рис. 31).

Противники цифровизации

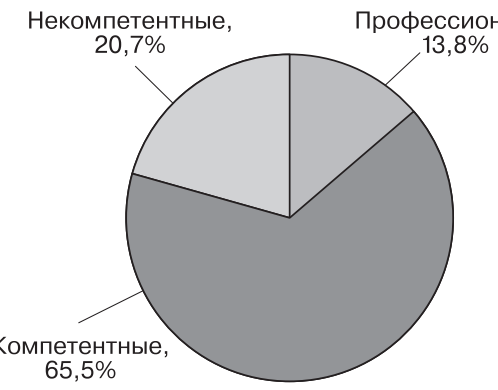

Сторонники цифровизации

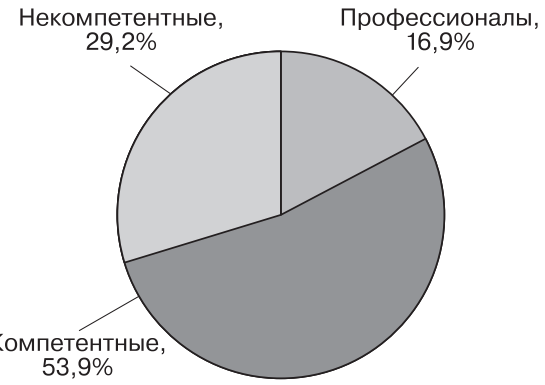

Puc. 31. Распределение сторонников и противников цифровизации по уровню компетентности

Отметим, что среди «сторонников» количество представителей полярных групп - «Профессионалов» и «Некомпетентных» в полтора раза выше, чем среди «противников» (16,9 и 29,2\% соответственно). Это можно объяснить тем, что люди, не испытывающие серьезных опасений, либо хорошо знают предмет, либо вообще в нем не ориентируются (по принципу «нет понимания - нет страхов»). А вот те, кто имеет средний уровень подготовленности (таких 65,5\% среди «противников» и 53,9\% среди «сторонников»), в определенных вопросах руководствуются непроверенной информацией из Интернета, слухами, мифами. Их неспособность к критическому анализу такой информации увеличивает тревожность и протестную активность. Дополнительным аргументом в пользу этого довода служит то, что в некоторых анкетах «протест» был никак не мотивирован: либо респондент не указывал никакой причины, либо комментировал свой протест общими фразами, например «Куда уж больше цифровых технологий??? Еще и в школе???».

Таким образом, можно констатировать, что основная часть родителей не против введения цифровизации в образовании, но уровень их цифровой компетентности может оказывать существенное влияние на степень их лояльности к переходу на новые способы обучения.

Отметим и еще один тренд, выявленный при опросе.

Анализ ответов респондентов на другие вопросы анкеты показал, что именно «Профессионалы» (то есть родители с самым высоким уровнем цифровой компетентности) имеют более четкую позицию по многим вопросам и испытывают меньше опасений от грядущих «цифровых» изменений. Их опасения связаны в большей степени с подготовленностью базы для введения цифровизации (техника, кадры), чем с ее негативным влиянием на субъектов.

Стоит обратить внимание на то, что ответы «Профессионалов» относительно перспектив влияния цифровизации на отношения субъектов образовательного процесса были более развернутыми и конкретными. Все 100\% «Профессионалов» отметили как позитивные, так и негативные последствия, в то время как «Некомпетентные» более чем в половине случаев оставляли 
данный вопрос без ответа либо ограничивались фразами типа «все зависит от конкретных людей», «ничего не могу сказать», «затрудняюсь ответить».

Что касается группы «Компетентных» (то есть тех, кто оценил свой уровень цифровой компетентности как средний), то среди них около $30 \%$ вообще не дали ответов на вопрос, связанный с перспективами развития отношений субъектов образовательного процесса. Можно предположить, что «цифровые» отношения в глазах этих респондентов также размыты, как и отношения реальные, - либо эти родители никогда о них особенно не задумывались, либо не считают их значимыми для себя. Прослеживается тенденция: чем более высокий уровень цифровой компетентности у родителей, тем объемнее их видение перспектив цифровизации в образовании и тем активнее они стремятся выразить свою точку зрения.

Кратко остановимся на тех образовательных дефицитах, которые называют родители в связи со своей цифровой компетентностью (о них заявили только родители со средним и низким уровнями цифровой компетентности). Помимо стандартного «не хватает знаний» родители отмечают и «недостаточность информации о возможностях, которые возникают при использовании цифровых технологий», и необходимость «развития навыков пользования как традиционными, так и цифровыми средствами обучения», переживают, что «родители не всегда готовы помочь ребенку, так как сами не подготовлены». Данные ответы формируют определенный образовательный запрос родителей к системе образования. Если учесть, что сегодня все большая часть мам и пап стараются включаться в школьные дела своих детей (об этом свидетельствуют активно функционирующие родительские чаты), то школе важно своевременно обрабатывать эти запросы и откликаться на них. Заметим, однако, что «откликаться» необходимо не только на проблемы, связанные с «цифровыми» образовательными процессами, но и на психолого-педагогические аспекты семейного воспитания. Именно проблемы, возникающие в семейной среде из-за гаджетов, компьютерных игр и снижения мотивации детей к продуктивным видам деятельности, рикошетом отражаются и на их школьной жизни.

Довольно существенным для определения цифрового профиля родителей являлся вопрос об их личном опыте в использовании цифровых технологий. Это, по мнению исследователей, помогло бы понять, на чем могут быть основаны энтузиазм сторонников и пессимизм противников цифровизации.

Основные результаты ответов на вопрос «Есть ли лично увас опыт использования цифровых технологий в учебном процессе ваших детей?» отражены в табл. 13. Подавляющее большинство родителей имели опыт использования цифровых технологий в образовании своих детей, хотя доля не имевших такого опыта представляется весьма существенной (в совокупности с количеством не ответивших утвердительно - более четверти).

Таблица 13

Распределение ответов родителей о наличии опыта использования цифровых технологий в учебном процессе их детей

\begin{tabular}{|l|c|}
\hline Вариант ответа & Доля выбравших данный вариант ответа от общего числа опрошенных, $\%$ \\
\hline Да & 74,6 \\
\hline Нет & 18,6 \\
\hline Не ответили & 6,8 \\
\hline
\end{tabular}


Самой показательной для нашего исследования является группа тех, кто затруднился с ответом (6,8\%). Можно предположить, что эти респонденты «что-то слышали» от своих детей или педагогов об использовании цифровых средств в образовании, но не понимают, можно ли отнести это к наличию опыта.

Анализ ответов респондентов позволил соотнести уровень цифровой компетентности родителей (ответы на вопрос № 2 анкеты), существенность (значимость для них) опасений в связи с введением цифровизации в школе (ответы на вопрос № 11) и имеющийся у них опыт использования цифровых технологий (ответы на вопрос № 3). Результаты отражены в табл. 14.

Таблица 14

\section{Распределение сторонников и противников цифровизации в зависимости от наличия опыта использования цифровых технологий в учебном процессе их детей}

\begin{tabular}{|l|c|c|c|}
\hline \multirow{2}{*}{ Вариант ответа } & \multicolumn{4}{|c|}{ Доля выбравших данный вариант ответа от общего числа опрошенных, \% } \\
\cline { 2 - 4 } & «Профессионалы» & «Компетентные» & «Некомпетентные» \\
\hline Против цифровизации & \multicolumn{5}{|l|}{} \\
\hline Есть «цифровой» опыт & 100 & 60,0 & 50,0 \\
\hline Нет «цифрового» опыта & - & 40,0 & 50,0 \\
\hline Не против цифровизации & \multicolumn{4}{|c|}{} \\
\hline Есть «цифровой» опыт & 100 & 91,0 & 78,6 \\
\hline Нет «цифрового» опыта & - & 9,0 & 21,4 \\
\hline
\end{tabular}

В группе «Профессионалов» у 100\% респондентов был цифровой опыт, поэтому их суждения, по всей видимости, имеют более объективную основу и отношение к цифровизации более осмысленное. Среди «Компетентных» около 40\% противников цифровизации не имели опыта использования цифровых технологий, а среди «Некомпетентных» родителей эта доля возросла до 50\%. Что касается сторонников цифровизации, то среди самой многочисленной группы респондентов («Компетентных») абсолютное большинство (91\%) имели цифровой опыт, а среди респондентов из группы «Некомпетентных» таких подавляющее большинство (78,6\%).

Соответственно, можно констатировать, что цифровой опыт родителей, полученный в процессе обучения ребенка, существенно влияет на их отношение к цифровизации: чем менее компетентным чувствует себя родитель в информационной/цифровой среде и чем меньше у него опыта взаимодействия с ней, тем более значимы его опасения.

Одно из опасений родителей касается трансформации отношений, которая, по их мнению, неизбежно наступит при переходе к цифровизации. Наиболее уязвимыми, по мнению родителей, при таком переходе станут отношения между детьми и учителями, а также между детьми и их сверстниками, а меньше всего пострадают отношения родителей в классе. В «среднюю» зону попадают детско-родительские отношения, однако причины их дестабилизации, указанные в ответах респондентов, настолько разнообразны, что их анализ требует отдельного изложения. 


\section{5. Демографический портрет родителей: «цифре» все возрасты покорны?}

Последний вопрос анкеты включал информацию о возрасте респондента и его детей. С исследовательской точки зрения была попытка выявить зависимость между возрастными особенностями респондентов и их отношением к цифровизации, а также ответить на вопрос, является ли количество детей (то есть опыт, приобретенный родителем в процессе их воспитания) детерминантой его «цифрового самоопределения» (сторонник или противник цифровизации).

Для выявления описанных выше закономерностей проводился статистический анализ данных. На рис. 32 приведена диаграмма, отражающая удельный вес каждой возрастной группы (в процентах). Основная масса родителей, которые участвовали в опросе, - это люди в возрасте 36-40 лет $(33,5 \%)$, однако тех, кто находится в пятилетнем диапазоне «до» и «после», тоже немало (26,5 и 26,0\% соответственно).

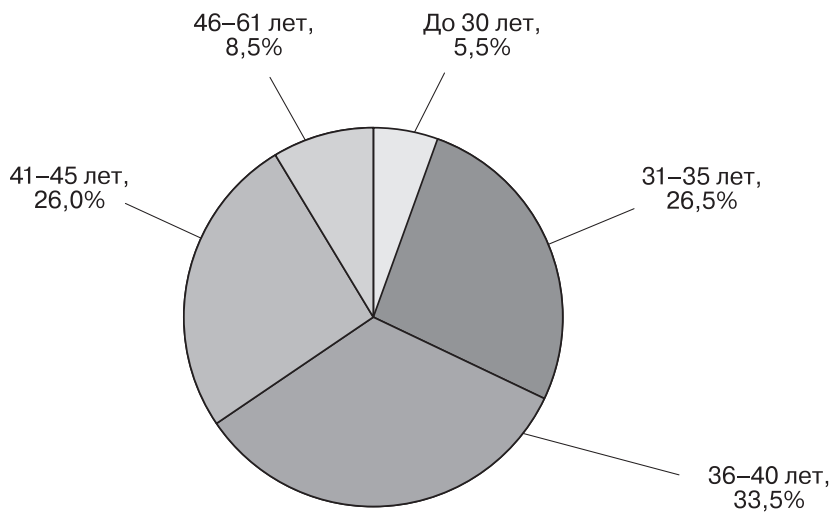

Puc. 32. Распределение респондентов по возрасту (доля от общего числа ответивших на вопрос)

Примечательно, что довольно велико количество респондентов старше 45 лет (46 и больше) - их 8,5\%. Это значит, что цифровая среда не для всех родителей может быть знакомой стихией, и этот факт необходимо учитывать при организации обучения с использованием цифровых технологий.

Сведения о возрастном составе респондентов отражены в табл. 15. Она приведена здесь для того, чтобы наглядно показать широту представленности родителей из разных поколений, дети которых учатся в начальной школе. Сам по себе этот факт очень показателен: мы привыкли, что в начальной школе учатся дети, родители которых относятся к одному поколению. Однако в сегодняшней школе можно наблюдать значительное отступление от этого «правила», и учителям приходится взаимодействовать с родителями очень разных возрастных групп. Соответственно, и аргументы при разговоре с ними должны быть разными, с учетом их жизненного, профессионального и родительского опыта.

Как видно из табл. 15, среди представителей тех, у кого дети учатся в начальной школе, есть родители и до 30 лет, и после 50. Это позволяет предположить, что консолидированные мнения родителей по проблеме цифровизации слабо связаны с их возрастом и поколенческими особенностями. 
Таблица 15

Распределение респондентов разного возраста по всем группам, чел.

\begin{tabular}{|c|c|c|c|c|c|c|c|}
\hline \multirow{2}{*}{ Возраст, лет } & \multirow{2}{*}{ Bcero } & \multicolumn{2}{|c|}{ «Профессионалы» } & \multicolumn{2}{|c|}{ «Компетентные» } & \multicolumn{2}{|c|}{ «Некомпетентные» } \\
\hline & & $3 a$ & Против & $3 a$ & Против & $3 a$ & Против \\
\hline Не ответили & 5 & 1 & - & 3 & - & 1 & - \\
\hline 29 & 1 & - & - & 1 & - & - & - \\
\hline 30 & 5 & - & - & 2 & 2 & 1 & - \\
\hline 31 & 2 & - & - & 1 & - & 1 & - \\
\hline 32 & 6 & 2 & - & 3 & - & 1 & - \\
\hline 33 & 5 & - & - & 2 & 1 & 2 & - \\
\hline 34 & 4 & 1 & - & 3 & - & 一 & - \\
\hline 35 & 15 & 2 & - & 5 & 2 & 3 & 3 \\
\hline 36 & 9 & 1 & - & 2 & 4 & 2 & - \\
\hline 37 & 9 & 2 & - & 4 & 1 & 2 & - \\
\hline 38 & 7 & - & 2 & 1 & 3 & 1 & - \\
\hline 39 & 11 & - & 1 & 5 & 3 & 2 & - \\
\hline 40 & 5 & - & - & 4 & - & - & 1 \\
\hline 41 & 7 & 1 & - & 4 & 1 & 1 & - \\
\hline 42 & 5 & 2 & - & 2 & - & 1 & - \\
\hline 43 & 4 & - & - & 1 & - & 2 & 1 \\
\hline 44 & 4 & - & - & - & - & 3 & 1 \\
\hline 45 & 5 & 1 & 1 & 1 & 1 & 1 & - \\
\hline 46 & 4 & 2 & - & 1 & - & 1 & - \\
\hline 47 & 2 & - & - & 1 & 1 & - & - \\
\hline 49 & 1 & - & - & 1 & - & - & - \\
\hline 53 & 1 & - & - & - & - & 1 & - \\
\hline 61 & 1 & - & - & 1 & - & - & - \\
\hline Итого & 118 & 15 & 4 & 48 & 19 & 26 & 6 \\
\hline
\end{tabular}

Заметим, что среди сторонников цифровизации возрастной диапазон составляет 29-61 год, в то время как среди противников он гораздо уже 30-47 лет. Несмотря на то что люди с возрастом обычно более осторожно относятся ко всему новому, в самой старшей возрастной группе (после 45 лет) только 1 человек из 9 является противником цифровизации.

Зависимости между возрастом и уровнем цифровой компетентности респондентов не выявлено.

Перейдем к анализу сведений о количестве детей, имеющихся у респондентов выделенных ранее групп, и возможной связи данного обстоятельства с их позицией в отношении к цифровизации (сторонники или противники).

В табл. 16 отражено количество детей у сторонников и противников цифровизации, а также количество детей у родителей с разными уровнями цифровой компетентности.

Анализ демографического профиля респондентов не выявил зависимости между количеством детей в семье и уровнем цифровой компетентности родителей. Во всех группах среднее количество детей на одного родителя приблизительно одинаковое - 1,7 или 1,8. 
Таблича 16

Распределение респондентов по количеству детей (все группы)

\begin{tabular}{|c|c|c|c|c|c|c|c|c|}
\hline \multirow{3}{*}{ Количество детей } & \multirow{2}{*}{\multicolumn{2}{|c|}{ Bcero }} & \multicolumn{6}{|c|}{ Число ответов } \\
\hline & & & \multicolumn{2}{|c|}{ «Профессионалы» } & \multicolumn{2}{|c|}{ «Компетентные» } & \multicolumn{2}{|c|}{ «Некомпетентные» } \\
\hline & Чел. & $\%$ & $3 a$ & Против & $3 a$ & Против & $3 A$ & Против \\
\hline Не ответили & 5 & 4,2 & 1 & 1 & 2 & - & 1 & - \\
\hline Ответили & 113 & 95,8 & 14 & 3 & 46 & 19 & 25 & 6 \\
\hline 1 & 49 & 43,3 & 8 & - & 21 & 8 & 10 & 2 \\
\hline 2 & 47 & 41,6 & 4 & 1 & 20 & 9 & 10 & 3 \\
\hline 3 & 15 & 13,3 & - & 2 & 5 & 2 & 5 & 1 \\
\hline 4 & 2 & 1,8 & 2 & - & - & - & - & - \\
\hline Сторонники & 85 & 75,2 & 14 & - & 46 & - & 25 & - \\
\hline 1 & 39 & 45,9 & 8 & - & 21 & - & 10 & - \\
\hline 2 & 34 & 40,0 & 4 & - & 20 & - & 10 & - \\
\hline 3 & 10 & 11,8 & - & - & 5 & - & 5 & - \\
\hline 4 & 2 & 2,3 & 2 & - & - & - & - & - \\
\hline Противники & 28 & 24,8 & - & 3 & - & 19 & - & 6 \\
\hline 1 & 10 & 35,7 & - & - & - & 8 & - & 2 \\
\hline 2 & 13 & 46,4 & - & 1 & - & 9 & - & 3 \\
\hline 3 & 5 & 17,9 & - & 2 & - & 2 & - & 1 \\
\hline «Профессионалы» & 17 & 15,0 & \multicolumn{6}{|c|}{$\begin{array}{l}\text { Общее количество детей }-32, \\
\text { в среднем на одного родителя }-\mathbf{1 , 8}\end{array}$} \\
\hline «Компетентные» & 65 & 57,5 & \multicolumn{6}{|c|}{$\begin{array}{l}\text { 0бщее количество детей }-108, \\
\text { в среднем на одного родителя }-\mathbf{1 , 7}\end{array}$} \\
\hline «Некомпетентные» & 31 & 27,5 & \multicolumn{6}{|c|}{$\begin{array}{l}\text { Общее количество детей }-56, \\
\text { в среднем на одного родителя }-\mathbf{1 , 8}\end{array}$} \\
\hline Сторонники & 85 & 72,0 & \multicolumn{6}{|c|}{$\begin{array}{l}\text { 0бщее количество детей }-135, \\
\text { в среднем на одного родителя }-\mathbf{1 , 6}\end{array}$} \\
\hline Противники & 28 & 23,72 & \multicolumn{6}{|c|}{$\begin{array}{l}\text { Общее количество детей }-51, \\
\text { в среднем на одного родителя - } \mathbf{1 , 8}\end{array}$} \\
\hline
\end{tabular}

Что касается связи количества детей и позиции респондента в отношении цифровизации, то здесь можно заметить определенный тренд: сторонники цифровизации имеют преимущественно одного ребенка. Удельный вес семей с двумя и тремя детьми в этой группе примерно на 6\% ниже, чем у противников (рис. 33).

И несмотря на то, что только в группе сторонников встречаются семьи с четырьмя детьми, можно предположить, что у противников цифровизации опыт столкновения с проблемами из-за гаджетов и Интернета немного выше. Кстати, и среднее количество детей на одного родителя в этих группах отличается - 1,6 у сторонников и 1,8 у противников. Скорее всего, именно опытом взаимодействия с разными средами можно объяснить более интенсивные реакции противников цифровизации на нововведения.

Таким образом, анализ демографических характеристик респондентов показал, что возрастной фактор не играет существенной роли в наличии цифровой компетентности у родителей и в их отношении к цифровизации. 
Сторонники цифровизации

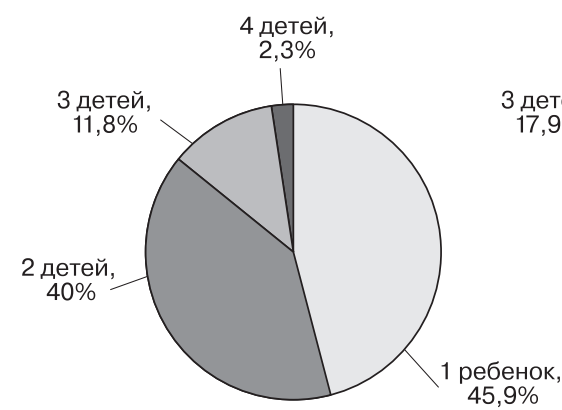

Противники цифровизации

4 детей,

о\%

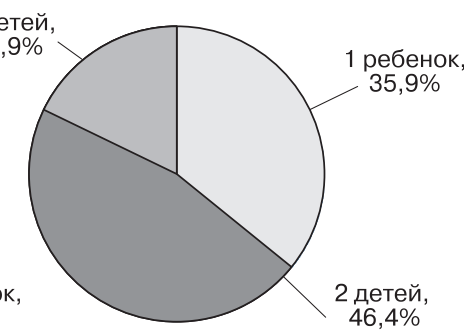

Puc. 33. Распределение сторонников и противников цифровизации по количеству детей в семье (доля от общего числа ответивших на вопрос в своей группе)

В то же время количество детей может являться дополнительным фактором при оценке родителями рисков цифровизации: чем больше у респондента детей, тем более критично он может быть настроен по отношению к нововведениям. Это значит, что при работе с семьей при переходе на цифровые технологии необходимо учитывать не только образовательную компоненту, но и семейный контекст, в котором воспитываются дети.

\section{Заключение}

Опрос родителей, проведенный накануне их реального столкновения с необходимостью сосуществования с цифровым миром, позволил увидеть несколько важных посылов системе образования.

1. Большинство родителей не понимают сути инновационных процессов, связанных с цифровой средой, обладают достаточно разрозненной и не всегда достоверной информацией о том, как устроено современное образование, какую роль в нем играют и будут играть дистанционные технологии, учитель, родители. Понимание того, что цифровизация предполагает иные отношения между участниками образовательного процесса, смену ролей и зон ответственности субъектов, у многих родителей учеников начальной школы пока не сформировано. Они практически не способны увидеть различия между цифровой образовательной платформой и «некачественным интернет-контентом», социальными сетями и специальным сервисом для общения учителей, учеников и родителей. Под цифровизацией они понимают и родительские чаты, и электронные дневники, и бесконтрольный интернетсерфинг ребенка.

2. Несмотря на непонимание, отношение к цифровизации у большинства опрошенных нами мам и пап позитивное, что создает потенциал доверия и к самим технологиям, и к школе, которая собирается их использовать.

Доминирующим мотивом позитивного отношения является не только расширение возможностей для образования и развития ребенка, но и увеличение мобильности в межгрупповой и межличностной коммуникации, ускорение многих актуальных для родителей процессов, снижение временны,х и материальных издержек.

Негативное отношение к цифровизации зачастую связано с «цифровой мифологией», вызванной недостаточной информированностью и компетентностью родителей. 
3. В целом уровень цифровой компетентности родителей учеников начальной школы можно назвать средним, хотя доля тех родителей, которые обладают высоким «цифровым потенциалом», достаточна для того, чтобы они могли стать своеобразными проводниками и даже экспертами в процессе развития цифровых технологий в образовании.

Анализ ответов респондентов в соответствии с их групповой принадлежностью показал, что по многим вопросам позиции родителей, имеющих разный уровень цифровой компетентности («Профессионалов», «Компетентных» и «Некомпетентных»), различаются, иногда существенно. Можно предположить, что повышение цифровой компетентности членов семьи позволит повлиять и на некоторые процессы, связанные с образовательными отношениями между субъектами.

4. Родители понимают, что «цифра» привнесет изменения и в их отношения со своим ребенком и школой. В целом эти изменения можно назвать позитивными. Наибольшее влияние, по мнению респондентов, цифровизация окажет на отношения детей с педагогами и сверстниками. Ухудшение этих отношений возможно из-за чрезмерной вовлеченности детей в цифровую среду, улучшение - из-за обнаружения общности интересов в ее освоении.

Однако большое значение родители придают тому, как будет вести себя учитель в этой новой ролевой модели - отстранится от ученика и отдаст процесс обучения искусственному интеллекту или будет использовать цифровые возможности для совместной учебной работы? Опасения родителей, связанные с возможным отчуждением учителя от учеников, детерминированы тем, что мамы и папы, даже молодые и «продвинутые», осознают свою психолого-педагогическую беспомощность перед цифровым миром и боятся потерять диалог с живым человеком, способным быстро прийти на помощь конкретному ребенку, обладающему своими особенностями. Родители страшатся вступить в неравный бой с цифровизацией и проиграть его. Это порождает возникновение разнообразных «цифровых барьеров», которые в настоящее время вызывают протестные настроения в обществе и заставляют родителей консолидироваться в борьбе против «цифры».

\section{Литература}

1. Александрова Е. А. Особенности современного семейного воспитания в России: ожидания и перспективы / Е. А. Александрова, А. И. Евдокимова, Н. А. Евдокимов, И. В. Таньчева // Человек и образование. 2021. № 1(66). С. 76-84.

2. Александрова Т. В., Костина Л. М. Семейные установки взрослых в связи с их детскими воспоминаниями о родительской семье // Азимут научных исследований: педагогика и психология. 2018. T. 7. № 4(25). С. $277-279$.

3. Барсукова О. В. Ребенок и гаджеты: психологическое исследование мнений современных родителей / О. В. Барсукова, Е. В. Мавлютова, М. А. Савка // Вопросы дошкольной педагогики. 2016. № 1. C. 14-18.

4. Будыкин С. В. Информационная безопасность детей и подростков в понимании родителей и учителей. Ч. 2. Результаты эмпирического исследования / С. В. Будыкин, Н. В. Дворянчиков, И. Б. Бовина // Психология и право. 2016. Т. 6. № 1. С. 25-38. D0l: 10.17759/psylaw.2016060104.

5. Коробкова В. В. Реализация концепции развития воспитательного потенциала семьи в открытом образовательном пространстве // Современная наука: актуальные проблемы теории и практики. Серия: Гуманитарные науки. 2015. № 11-12. С. 83-88. 
6. Малыгин В. Л. Особенности ценностных ориентаций у подростков с интернет-зависимым поведением / В. Л. Малыгин, Ю. А. Меркурьева, А. Б. Искандирова, Е. Е. Пахтусова, А. В. Прокофьева // Медицинская психология в России. 2015. № 4(33) [Электронный ресурc]. URL: https://cyberleninka. ru/article/n/osobennosti-tsennostnyh-orientatsiy-u-podrostkov-s-internet-zavisimym-povedeniem (дата обращения: 16.07.2021).

7. Нафиса Х., Алиджон Х. Влияние ИКТ-знаний родителей на уровень взаимодействия с детьми в образовательном процессе в школах Исламской Республики Иран // Вестник Таджикского национального университета. 2014. № 3-6. С. 207-210.

8. Писаренко И. А., Заиченко Л. И. Родители как субъекты влияния на развитие цифровых навыков детей // Интеракция. Интервью. Интерпретация. 2021. T. 13. № 2. C. 54-80. D0I: https://doi. org/10.19181/inter.2021.13.2.4

9. Хоменко И. А. Квопросу об определении понятия «семейное воспитание» // Ученые записки СанктПетербургского государственного института психологии и социальной работы. 2012. Т. 17. Вып. 1. C. 88-93.

10. Хоменко И. А. Педагогическая стратегия развития семейного воспитания в современной России // Народное образование. 2013. № 1. С. 63-68.

11. Цифровая компетентность подростков и родителей. Результаты всероссийского исследования / Г. У. Солдатова, Т. А. Нестик, Е. И. Рассказова, Е. Ю. Зотова. М. : Фонд Развития Интернет, 2013. 144 с.

12. Amorós-Martí $P$. "Learning together, growing with family": The implementation and evaluation of a family support programme / P. Amorós-Martí, S. Byrne, A. Mateos-Inchaurrondo, E. Vaquero-Tió, A. Mundet-Bolós // Psychosocial Intervention. 2016. V. 25 (2). P. 87-93.

13. Dardanou M. Use of touchscreen technology by $0-3$-year-old children: Parents' practices and perspectives in Norway, Portugal and Japan / M. Dardanou, T. Unstad, P. Dias, O. Fotakopoulou, Y. Sakata, J. 0'Connor // Journal of Early Childhood Literacy. 2020. V. 20 (3). P. 551-573 [Электронный ресурс]. URL: https://doi.org/10.1177/1468798420938445 (date of access: 15.07.2021).

14. Dias $P$. The role of parents in the engagement of young children with digital technologies: Exploring tensions between rights of access and protection, from 'Gatekeepers' to 'Scaffolders' / P. Dias, R. Brito, W. Ribbens [et al] // Global Studies of Childhood. 2016. V. 6 (4). P. 414-427 [Электронный ресурс]. D0l: https://doi.org/10.1177/2043610616676024

15. Dong S. Children's Temperament and Maternal Behavioral Control: Origins of Heterogeneity in Developmental Trajectories of Committed Compliance from Infancy to Age 3 / S. Dong, Z. Wang, S. Lu [et al] // Journal of Child and Family Studies. 2018. V. 27 (8). P. 2668-2677.

16. Frazer A. L. Parental criticism moderates sibling influence on proactive and reactive aggression / A. L. Frazer, P. J. Fite, K. J. Stone, J. Clinkenbeard // Journal of Child and Family Studies. 2018. V. 27 (12). P. 4025-4032.

17. Gunderson E. A. The specificity of parenting effects: Differential relations of parent praise and criticism to children's theories of intelligence and learning goals / E. A. Gunderson, M. B. Donnellan, R. W. Robins, K. H. Trzesniewski // Journal of Experimental Child Psychology. 2018. V. 173. P. 116-135.

18. Harding J. F. The Relationship Between Maternal Education and Children's Academic Outcomes: A Theoretical Framework / J. F. Harding, P. A. Morris, D. Hughes // Journal of Marriage and Family. 2015. V. 77 (1). P. $60-76$.

19. Neufeld G. Hold On to Your Kids. Random House LLC, 2006. P. 320.

20. Padilla-Walker L.M. The role of parental warmth and hostility on adolescents' prosocial behavior toward multiple targets / L. M. Padilla-Walker, M. G. Nielson, R. D. Day // Journal of Family Psychology. 2016. V. 30 (3). P. $331-340$.

21. Turkle S. Reclaiming Conversation: The Power of Talk in a Digital Age. Penguin Press, 2015. 


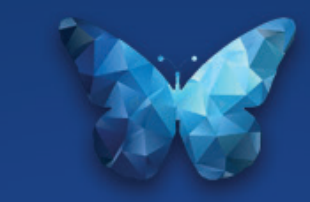

Раздел IV

ЭКСПЕРИМЕНТ 



\section{ГЛАВА 8}

\section{Индивидуальный тренинг в цифровой среде}

Одной из составляющих проекта «Управление развитием образовательных отношений субъектов в начальной школе в условиях цифровизации» является проведение экспериментальной работы на образовательных площадках с последующей разработкой методических рекомендаций для школ, планирующих переход к новым формам организации учебного процесса. Раздел IV «Эксперимент» монографии состоит из двух глав: данная глава содержит научно-педагогическое обоснование инновационной учебной практики, в рамках которой изучаются действия различных субъектов учебного процесса и их взаимоотношения; глава 9 посвящена непосредственно описанию пилотного эксперимента в школах.

Ключевой методологической идеей нашего эксперимента является исследование действий и взаимодействий субъектов учебного процесса в ходе инновационной практики - компьютерного тренинга. Эта активная форма учебной деятельности обучающихся, поддерживаемая различными инструментами обратной связи, может рассматриваться как важная составляющая обучения в начальной школе. В настоящем исследовании под тренингом мы будем понимать повторяющиеся учебные действия, цель которых — формирование и развитие различных умений и навыков. Другими словами, тренинг - это выполнение рутинных операций, производимое до наступления того момента, когда обучающийся начинает безошибочно выполнять необходимые действия, оперируя различными исходными данными.

Идея тренинга как активного учения в целом соответствует деятельностному подходу, который строит процесс обучения вокруг личности обучающегося, и в этом плане тренинг имеет надежную научно-педагогическую основу [Леонтьев]. На стадии цифровизации компьютер становится не только инструментом учебной деятельности, но и источником сигнала обратной связи для обучающегося. Возрастает значимость компьютерного тренинга для процесса обучения в целом ${ }^{39}$, а задача разработки соответствующих методических и дидактических материалов для проведения тренинга приобретает особую актуальность в период поисков новой дидактики. Вот, например, мнение ведущего эксперта Г. С. Ковалевой: «Качество образовательных достижений школьников в основном определяется качеством учебных заданий, предлагаемых им педагогами» ${ }^{40}$. Описываемый в главе 9 пилотный эксперимент основан на оригинальном подходе к созданию тренинговых

39 Подробно эта тема освещена в главе 3 данной монографии.

40 Из выступления на конференции ЕАОКО (Минск, 2019 г.), см.: Восьмая ежегодная международная конференция Евразийской Ассоциации оценки качества образования [Электронный ресурс]. URL: https://eaoko.org/ru/events/EAOKO-2019.html (дата обращения: 12.07.2021). 
заданий, нацеленных на формирование и отладку когнитивных алгоритмов у обучающихся в начальной школе. Ниже приведено обоснование этого подхода через сопоставление учебной практики, в ходе которой дети многократно выполняют рутинные операции, с процессом отладки компьютерных алгоритмов.

\section{1. Алгоритмическая основа когнитивного развития}

Цифровая трансформация школы является необходимым следствием процессов модернизации, затрагивающих все социальные сферы. Цифровизация иногда рассматривается как углубление и закрепление изменений, привнесенных в образовательный процесс в рамках компьютеризации и информатизации [Уваров], однако можно выделить и существенные отличия, характерные именно для этой стадии инновационного развития школы. Новое качество заключается в том, что в фокусе изменений оказывается не столько доступность различных источников образовательной информации и программных инструментов, как это было на предыдущих стадиях, сколько перенос в цифровую среду всей системы отношений, существующей сегодня в школе и вокруг нее.

Цифровизация школы не оставляет в стороне ни педагогов, ни администраторов, ни родителей, ни самих школьников. Всем придется столкнуться с новой реальностью, адаптироваться к ней, переведя все виды учебной, педагогической и управленческой деятельности «на цифровые рельсы». Цифровизация во многом уравняет на единой технологической основе субъект-субъектные отношения между людьми и отношения типа «человек компьютер». Эта тенденция проявится в первую очередь в формализации и регламентации межсубъектных отношений.

Все виды деятельности, связанные с использованием компьютера как инструмента, опираются на алгоритмы, реализованные в виде программных процедур. Говоря техническим языком, в цифровой среде человек, как и компьютер, оказывается исполнителем определенных алгоритмов. Механизмом трансформации становится взаимодействие участников образовательных отношений на цифровой платформе, а основой отношений - «алгоритмизация взаимодействия участников платформы: процедуры взаимодействия участников детерминированы и реализуются в рамках установленного алгоритма» ${ }^{41}$. Межсубъектные взаимодействия, которым раньше (несмотря на наличие ведомственных стандартов, должностных инструкций и регламентов) все же были присущи гибкость в принятии решений, нечеткость правил, субъективность, становятся гораздо более жестко структурированными и контролируемыми на соответствие установленным процедурам.

Перспектива сосуществования людей и компьютеров в образовательной среде привлекает все большее внимание к сравнению механизмов функционирования естественного и искусственного интеллектов. Впервые эта тема стала предметом научного анализа в классическом труде Дж. фон Неймана «Вычислительная машина и мозг» [Нейман]. Сравнивая алгоритмическую

41 Проект «Подходы к определению и типизации цифровых платформ» // Цифровая экономика [Электронный ресурс]. URL: https://files.data-economy.ru/digital_platforms_project.pdf (дата обращения: 12.07.2021). 
основу поведения человека и функционирования вычислительной машины, Нейман предложил концепцию создания искусственного, то есть компьютерного, интеллекта. Сегодня, как и в середине XX в., эта тема вновь находится в фокусе общественного внимания, теперь не только в научном, но и в практическом аспекте. Растет число публикаций, посвященных сравнительному анализу процессов интеллектуального развития и самообучения нейронных сетей, то есть сопоставлению принципов обучения компьютера и человека.

Направленность большинства исследований связана с цифровой реконструкцией естественных процессов когнитивного развития. Эта проблематика рассматривается в контексте создания программного обеспечения, предназначенного для автоматического выполнения тех или иных функций, ранее относившихся к сфере ответственности человека. Компьютер рассматривается как аналог человеческого мозга, обладающий мощным и при этом развивающимся интеллектом. Однако в новой реальности неменьший интерес представляет и обратный ракурс: «мозг как компьютер». Или, другими словами: как алгоритмически должно быть построено обучение человека, чтобы результаты его развития отвечали потребностям цифрового общества? Этот вопрос приобретает особую актуальность в контексте междисциплинарных исследований, совмещающих методологию наук об образовании и технических наук.

В условиях цифровой модернизации существенно изменяется информационно-образовательная среда, поэтому появляются основания для пересмотра некоторых традиционных представлений гуманитарных наук. Педагогическая психология как наука, изучающая методы обучения и воспитания, не может игнорировать существенные изменения в поведении обучающихся, вызываемые влиянием различных источников информации. В предшествующие десятилетия в России развивалась преимущественно деятельностная теория учения, а когнитивному подходу уделялось меньше внимания. В частности, информационные теории критиковались за то, что «познавательная деятельность человека отождествляется с процессами, происходящими в компьютерах» [Талызина]. Представляется, однако, что значимые социальные и технологические изменения заставляют с бо́льшим вниманием отнестись к анализу сходств и различий между процессами, лежащими в основе обучения (в частности, обучения детей в начальной школе), и алгоритмическим по сути поведением компьютерных систем. Речь, конечно, идет не о противопоставлении когнитивного (информационного) подхода деятельностному, а об их сочетании.

\section{2. «Эвристическая» и «алгоритмическая» составляющие познавательной деятельности}

Представление о том, что познавательная деятельность основывается на определенных алгоритмах, становится все более распространенным в преддверии наступления эры искусственного интеллекта. Если компьютер можно научить решать интеллектуальные задачи, почему бы не использовать алгоритмическую модель в учебных практиках, представляя решение учебной задачи в виде последовательности определенных мыслительных операций? 
На первый взгляд кажется, что такая постановка вопроса противоречит принципам современной педагогики, которая не одобряет шаблонов в интеллектуальном развитии, призывает к развитию креативных способностей, поддерживает проявления индивидуальности. Однако поиск новых решений, эвристическая деятельность не могут развиваться без опоры на надежный фундамент: «для того, чтобы познавать, необходимо вначале уметь познавать. Это умение должно предшествовать познанию. Мозг должен иметь какие-то изначально заложенные программы переработки информации» [Аллахвердов]. Когда речь идет об искусственном интеллекте (самообучающиеся системы), все осознают, что сложные алгоритмы не возникают на пустом месте, а могут работать лишь в подготовленной, заранее созданной операционной среде. Можно предположить, что и применительно к человеку должны действовать аналогичные механизмы. Необходимо научиться находить в обучении баланс между двумя составляющими, которые можно условно назвать «эвристической» и «алгоритмической».

В предисловии к третьему изданию (2012) книги Дж. фон Неймана [Нейман] Р. Курцвейл описал структуры, на которых основано восприятие информации мозгом: «Кора головного мозга представляет собой иерархию распознавателей шаблонов». Простейшие шаблоны позволяют человеку различать элементарные зрительные образы. По мере продвижения вверх по этой иерархии человеку становится доступным распознавание все более сложных объектов: букв (символов), слов, предметов, ассоциаций и т. д. Хотя современная наука не может пока с достаточной точностью описать физиологические процессы, приводящие к переходу от простых шаблонов к более сложным, компьютерные аналогии могут помочь в выдвижении гипотез, продуктивных в контексте создания методик обучения и учебных практик, особенно на начальной ступени образования, когда человек только «учится познавать».

В этой логике мозг взрослого человека, получившего полноценное общее и тем более профессиональное образование, можно сравнить с компьютером хорошей конфигурации, оснащенным всем необходимым для его деятельности программным обеспечением. Это сложный комплекс, в котором можно найти аналоги операционной системы, библиотеки стандартных функций, прикладные программы и т. п. Такой «компьютер» обеспечивает своего пользователя необходимыми для различных видов деятельности инструментами, его возможности можно улучшать (hardware upgrade, software update), что соответствует концепции «учиться всю жизнь». Но все же «базовая конфигурация» создается преимущественно формальным образованием.

Теперь попытаемся найти «компьютерные» аналогии для ребенка, который находится на начальной стадии систематического обучения. Потенциальные возможности его мозга пока что используются крайне незначительно. Еще только предстоит выстроить иерархию когнитивных шаблонов, которые станут основой его интеллекта, способности решать разнообразные задачи.

Алгоритмическая природа интеллекта ребенка так же несомненна, как и взрослого, только доступные ему алгоритмы пока значительно проще. Когда ребенок приходит в школу, он оперирует только базовыми операциями простейшими навыками (да и они еще тоже не совсем «отлажены»). Если в плане органов чувств его познавательные возможности уже в значительной 
степени сформированы, то алгоритмическое обеспечение еще только предстоит выстроить шаг за шагом. По мере того как усложняются выполняемые ребенком учебные действия, совершенствуется не только «программное обеспечение», но и сам мозг. Как формулирует Т. В. Черниговская: «Обучение меняет мозг человека в физическом смысле: увеличивается качество нейронной сети, то есть растет серое и белое вещества» ${ }^{42}$. Активный тренинг, связанный с регулярным выполнением действий интеллектуального характера, важен не только для когнитивного, но и для физиологического развития.

На ранней ступени ребенок еще не способен распознавать уже известные ему по предыдущему опыту типы заданий. С алгоритмической точки зрения это означает, что для каждой задачи логика решения, «блок-схема» строится заново. Только позднее становится возможным обобщение, доступные мозгу алгоритмы приобретают способность типологизировать различные учебные задачи. Ребенок обретает способность «распознавать» задачи, с которыми он уже сталкивался, и перестает решать каждую задачу «с нуля». Это происходит только в процессе систематического учения, а пока оно еще не началось, мозг «обычного» ребенка можно сравнить не с хорошо оснащенным компьютером, а с только что приобретенным гаджетом, на который еще предстоит установить все необходимые приложения и настроить в соответствии с собственными предпочтениями пользователя.

Взрослых система образования и собственный повседневный опыт уже познакомили со многими закономерностями, правилами, условностями. Каждый, кто учился в школе, знаком со значениями многих понятий, терминов, символов, пока еще неизвестных ребенку. Детям эти взрослые «конвенции» пока неведомы, с ними приходится знакомиться в процессе обучения, общаясь со старшими, перенимая их приемы и методы. В формальном обучении учителя передают детям «опыт человечества», а также свои собственные представления о том, как решается та или иная задача.

Процесс передачи навыков и умений - это не формальное копирование «матрицы» готового решения от взрослого ребенку. Это адаптация алгоритма действий одного - уже обученного — исполнителя для другого, обладающего пока что меньшими возможностями (как бы сокращенной системой выполняемых операций). Чтобы убедиться в том, что перенос алгоритма произведен корректно, нужно проверить его в действии. Мало объяснений учителя, нужна самостоятельная учебная деятельность, индивидуальная практика, которая поможет убедиться самому и убедить других, что требуемые умения действительно сформировались.

\section{3. Элементарные учебные действия}

В какой степени аналогия между стимулированием когнитивной деятельности ребенка и созданием программного обеспечения компьютера может помочь в решении дидактических задач? В этой логике, связывающей достижение определенных образовательных результатов с усложнением

42 Разговор с Татьяной Черниговской // Прямая речь [Электронный ресурc]. URL: https:// www.pryamaya.ru/tatyana_chernigovskaya_beseda_s_tatyanoy_chernigovskoy_11.07 (дата обращения: 07.09.2021). 
алгоритмического обеспечения мозга ребенка, следует найти подходящие аналогии и для самого процесса обучения. Любой алгоритм должен быть корректно составлен, а его программная реализация должна давать правильные (с точки зрения составителя) результаты. Корректность функционирования проверяется в процессе отладки. Отлаженная программа стабильно работает и может оперировать различными входными данными (в границах используемой информационной модели).

Если вышеизложенное перевести с компьютерного языка на педагогический, то можно отметить сходство целей отладки программы и обучения ребенка, а именно: корректное и при этом стабильное выполнение заданных функций (учебных действий) вне зависимости от условий конкретной задачи данного типа. Есть все основания для сопоставления учебной практики, направленной на формирование умений, с отладкой алгоритма. Поэтому в условиях цифровизации может возникнуть оправданная педагогическая потребность в заимствовании приемов тестирования программного обеспечения для достижения результативности процесса обучения.

Алгоритм, лежащий в основе любой программы, является абстрактной управляющей моделью. Программист должен добиться, чтобы эта модель обеспечивала необходимое поведение компьютера или другого исполнителя алгоритма. Чтобы подтвердить, что написанная программа соответствует логике исходной модели, недостаточно один раз запустить ее на исполнение и убедиться, что получен правильный итоговый результат. Обычно в ходе отладки приходится проверять работу не только программы в целом, но и отдельных ее частей. Для этого в программном коде предусматриваются «контрольные точки», позволяющие выявлять операции, результат которых не соответствует ожидаемому.

Когда речь идет об учебных действиях, точно так же следует обеспечить возможность отладки за счет разделения когнитивного алгоритма на проверяемые операции. Это значит, что при разработке учебных заданий также следует предусмотреть в предполагаемом алгоритме выполнения «контрольные точки», чтобы иметь возможность анализировать не только итоговый результат, но и процесс решения.

Эти промежуточные результаты прохождения познавательного алгоритма естественно связывать с выполнением элементарных учебных действий (далее - ЭУД). К подобным действиям могут относиться различные операции с информационными объектами, в том числе нахождение нужных сведений в информационном источнике, списывание, выполнение арифметической операции, логического вывода, сравнение и т. д. Поясним содержание этого понятия на простых примерах. Пусть дана задача, где нужно определить площадь прямоугольника. Чтобы решить ее, ученик должен найти в условии сведения о длине одной стороны (чтение), затем другой стороны (чтение), затем перемножить эти величины (вычисление) и записать результат в требуемой форме (письмо). А, например, в задании, где требуется записать в таблицу, в какое море впадает река Енисей, нужно найти название этой реки на карте (чтение графической информации), определить направление ее течения (чтение графической информации), проследить путь до устья (логический вывод), прочитать название моря (чтение) и аккуратно вписать его в нужную ячейку (запись в таблицу).

В каждом из этих ЭУД могут быть допущены ошибки, и их происхождение может быть различным (извлечены неверные исходные данные, ошибка 
в вычислении, некорректное написание названия географического объекта и т. п.). Педагог, заинтересованный в формировании у обучающихся устойчивых навыков и умений, не должен полагаться только на проверку ответа. Даже если ответ верен (он мог быть угадан, подсказан, получен в результате наложения нескольких ошибок), нужно проверить, что не было допущено ошибок на промежуточных шагах. А если получен неверный ответ, тем более важно разобраться, в каком месте цепочки ЭУд была допущена ошибка.

Идея фиксации и проверки всех выполняемых ЭУд была положена в основу экспериментального исследования ${ }^{43}$, в котором анализу подвергались типы ошибок, допускаемых обучающимися при выполнении заданий метапредметного типа. Участники эксперимента работали на образовательной платформе, а ход и результаты фиксировались для анализа и интерпретации в виде «цифрового следа». Пример фрагмента записанного следа выполнения задания (трека) приведен на рис. 34.

\footnotetext{
Площадь Африки - самого жаркого материка - составляет 30 миллионов квадратных километров Площадь Африка - самого жаргого материка - составляет 30 миллионов квадратных километров Площадь Африка - самого жаркого материка - составляет 30 миллионов квадратных километров Площадь Африки - самого жаркого материка - составляет 30 миллионов квадратных километров
}

Puc. 34. Пример фиксации результатов выполнения заданий учащимся (трек)

На рис. 34 отображена часть действий ученика, связанных с выполнением одного из заданий тренинга. В этом задании на экране были даны несколько фраз с пробелами, в которые требовалось вписать пропущенные слова. Верхняя строка трека - это тот правильный ответ, который программа готова принять. Следующие строки - это попытки ученика выполнить необходимые ЭУД. Видно, что уже в первой попытке он выбрал нужные по смыслу слова, однако не проверил написанное, в результате чего программа выявила ошибочные действия. После этого, как мы видим, ученик исправил опечатку в слове «жаркого», но не обратил внимания, что слово «Африка» стоит в неверном падеже. Поэтому ему пришлось сделать еще одну попытку, после чего компьютер принял ответ. Очевидно, что ошибка была найдена в результате двух итераций. Анализируя природу допущенных ошибок, можно предположить, что ученик не уделил достаточно внимания проверке результатов каждого из выполненных ЭУД. Дальнейшая работа с этим учеником должна быть нацелена на развитие умения находить и исправлять ошибки списывания непосредственно в первой попытке, а не после получения сигнала об ошибке от компьютера.

Еще одно важное обстоятельство проясняется благодаря рассмотрению аналогии между тренингом и отладкой программы. И в программировании, и в обучении различные на первый взгляд ошибки имеют общую причину, являются следствием того, что некорректно выполняются одни и те же операции. Например, если в электронной таблице неправильно заданы правила округления, это будет проявляться в некорректности данных, получаемых при решении задач различного содержания. Так же обстоит дело и с действиями ребенка. Если он не научился внимательно читать задание, он может по этой причине допускать ошибки в любых типах ЭУД: и в вычислениях,

43 Экспериментальная работа на образовательных площадках и аналитика цифрового следа подробно описаны в главе 9. 
и в логических умозаключениях, и в ответах на конкретные вопросы. И в том и в другом примерах проявления ошибок разные, а причина у них общая: некорректная реализация исполняемого алгоритма. Учителю важно научиться типологизировать и систематизировать обнаруживаемые ошибки, а не рассматривать каждую учебную задачу в отдельности. При анализе и интерпретации некорректных действий обучающегося нужно стремиться найти те ЭУД, выполнение которых у данного ребенка регулярно приводит к ошибкам, то есть выявить корневые причины отклонения от правильного выполнения алгоритма.

Описанная выше концепция, основанная на анализе выполнения ЭУД, кардинальным образом отличается от методов оценивания, используемых в сегодняшней массовой школе. Образовательные результаты формулируются чаще всего в описательном ключе, с опорой на плохо формализуемые и плохо проверяемые понятия. Например, основой существующих образовательных стандартов является универсальное учебное действие (УУД), введенное в современную практику, в частности, А. Г. Асмоловым [Асмолов]. Формирование УУД является ключевой идеей различных методических подходов, рекомендуемых для использования в массовой школе. УУД, понимаемые как «совокупность способов действий учащегося и навыков учебной работы» [Там же] - это скорее рамочный индикатор, нежели практически используемый критерий для оценки результативности обучения. В образовательных отношениях, которые возникают в процессе цифровой трансформации, такой нечетко определенный индикатор не может использоваться из-за субъективности трактовок и невозможности однозначного решения, понимаемого и принимаемого всеми субъектами учебного процесса. ЭУД как элементарное действие может рассматриваться как «единица анализа учения», что дает основание для практической реализации идей деятельностного подхода [Рубинштейн] в условиях, когда компьютер становится частью учебного процесса.

Многие создатели дидактических материалов для младших классов считают приоритетными задания, где есть элемент творчества, а безошибочности рутинных действий уделяют меньше внимания. Стремясь к унификации тестовых заданий, они чаще всего используют модель теста как «черного ящика» (рис. $35, a)$. Проверяется соответствие полученного обучающимся ответа заданному, но ход решения задачи (то есть алгоритм действий ребенка) остается скрытым от педагога. Логика процесса отладки требует другой модели (рис. 35, 6). Мало проверять итоговый ответ, полученный учеником при выполнении задания, - важно убедиться, каким путем он пришел к этому ответу. Имея доступ к «контрольным точкам», педагог получает возможность восстановить ход выполнения задания, понять и объяснить ученику природу допущенной ошибки (непонимание формулировки задания, невнимательность, неумение выполнять определенные действия и т. д.). В технике эти данные, фиксирующие наличие некорректных действий, называются синдромом ошибки и служат для коррекции действия исполнителя алгоритма (в данном случае обучающегося).

Эта техническая аналогия подчеркивает, что переход от теоретической постановки образовательных задач к учебным практикам требует дробления когнитивного алгоритма на проверяемые элементарные операции для контроля корректности всего хода выполнения задания, а не только проверки результата. 


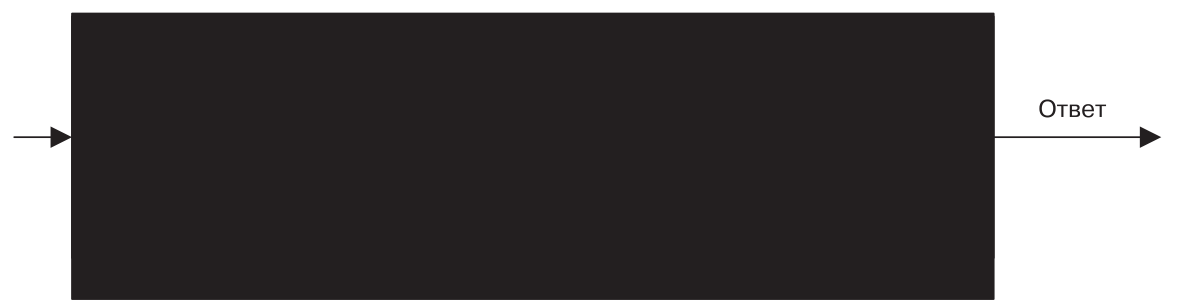

а) тест как «черный ящик»

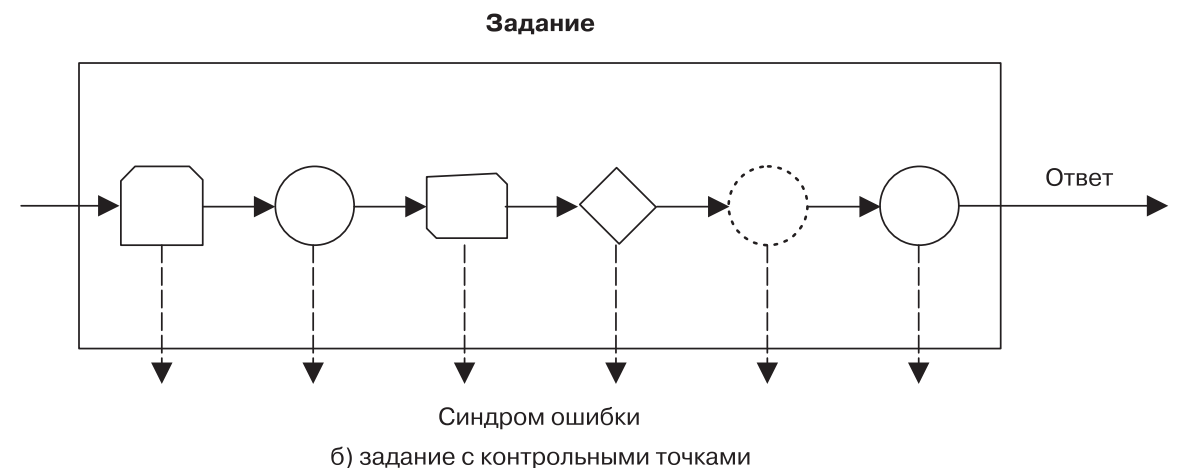

Puc. 35. Контрольные точки в алгоритме выполнения задания

Завершая сравнение двух подходов к разработке дидактических материалов, уместно еще раз сослаться на мнение ведущего российского эксперта по исследованиям PISA Г. С. Ковалевой, которая в своих выступлениях сетует на дефицит учебных заданий, которые позволяли бы не только проверять, но и формировать значимые умения метапредметного типа, необходимые, чтобы наилучшим образом подготовить российских школьников к международной конкуренции ${ }^{44}$.

\section{4. Алгоритмические основы функциональной грамотности}

Возвращаясь к идее баланса между «эвристической» и «алгоритмической» составляющими процесса обучения, можно отметить, что понятие УУД применимо в широко понимаемой образовательной деятельности, но для собственно учебных действий формального обучения планируемые результаты и критерии оценивания должны формулироваться как набор «тактических целей». В первую очередь это требование важно для достижения тех базовых результатов, без которых невозможно полноценное дальнейшее обучение. В начальной школе умению учиться следует уделять особое внимание, чтобы все необходимые ЭУД выполнялись с точностью и безошибочностью отлаженной компьютерной программы. Эти базовые навыки и умения являются инвариантной составляющей любой траектории обучения в

${ }^{44}$ См., например: Восьмая ежегодная международная конференция Евразийской Ассоциации оценки качества образования [Электронный ресурc]. URL: https://eaoko.org/ru/events/ EAOKO-2019.html (дата обращения: 12.07.2021). 
начальной школе, которая может быть соотнесена с понятием «грамотность» в современном его понимании.

Приняв за основу эту метафору, будем разбираться, какие алгоритмические решения должны быть предложены ребенку в качестве базового слоя (ядра), чтобы поверх него можно было постепенно конструировать полноценное «программное обеспечение»: различные компетенции, «навыки XXI века» и все прочее, что относится к «эвристической» составляющей.

Большинство элементарных операций компьютера имеют трехзвенную структуру: «ввод - преобразование - вывод». Процессор считывает исходную информацию из памяти или с устройства ввода, преобразует ее в соответствии с выполняемой командой и выводит результат на внешнее устройство (или временно записывает его туда, где он будет храниться для последующего использования). Развивая эту аналогию, можно и в простейших мыслительных операциях зафиксировать те же три звена: «чтение преобразование - письмо». Здесь уместно воспользоваться определением такой характеристики, как функциональная грамотность, принадлежащим А. А. Леонтьеву: «Функциональная грамотность - это способность человека свободно использовать навыки и умения чтения и письма для получения информации из текста, то есть для его понимания, компрессии, трансформации и так далее (чтение) и для передачи такой информации в реальном общении (письмо)» [Леонтьев 2002]. Отметим, что взгляд ученого подтверждает правомерность предположений, сделанных на основании технических аналогий.

Приведенное определение появилось задолго до феномена цифровизации, а современная трактовка функциональной грамотности дополняет информационный аспект инструментальным. В исследовании «Российская школа: начало XXI века» уточняется: «Важно отметить, что в настоящее время функциональная грамотность рассматривается как навыки работы с информацией, представленной в таких различных форматах, как печатные и визуальные материалы (книги, журналы, знаки, постеры и т. д.), а также различные медианосители (радио, телевизор, компьютер или смартфон)» [Российская школа...]. В этой формулировке подчеркивается ключевая роль действий с информацией, которые укладываются в расширительно понимаемые понятия чтения и письма. Обратим внимание, что функциональная грамотность базируется на умении работать с информацией, не вписанной в контекст конкретного учебного предмета. Другими словами, формирование функциональной грамотности относится к тем метапредметным результатам, которые должны предшествовать предметному обучению, - это задача начальной школы.

Сопоставляя определение А. А. Леонтьева с приведенной выше трехзвенной цепочкой «ввод - преобразование - вывод», можно предположить, что функциональная грамотность представляет собой алгоритмическое ядро дальнейшего обучения. Действия с учебной информацией носят универсальный характер, соответствующие навыки и умения должны формироваться на начальной стадии обучения, пока учебный процесс еще не стал расходиться по предметным колеям. В педагогический арсенал начальной школы должен быть встроен процесс отладки алгоритмов, лежащих в основе функциональной грамотности, то есть требуется практика, состоящая в выполнении каждым ребенком необходимых ЭУД и их оценивании.

Определение А. А. Леонтьева представляется соответствующим практическим потребностям. На его основе можно не только формулировать требо- 
вания к образовательным результатам, но и строить соответствующую этой цели дидактику, разрабатывать необходимые контрольно-измерительные материалы, методы и критерии оценивания.

Переформулируем определение функциональной грамотности таким образом, чтобы стал ясен алгоритм выполнения учебных действий. Эту когнитивную цепочку мы будем называть ReACT. Расшифруем:

- $R e$ - read - читаем. Здесь подразумевается восприятие обучающимся исходной информации, в каком бы формате она ни была представлена. Это может быть в буквальном смысле чтение текста, но к этому же типу действий относятся считывание сведений с карты, схемы, таблицы, восприятие информации на слух и т. д. Информация может быть статичной или динамически меняться - в любом случае мы говорим о чтении, понимая этот термин в расширительном смысле;

- A-analyse - анализируем. Если первая фаза - это непосредственное восприятие информации, то второе звено предполагает соотнесение полученных сведений с заданием, то есть включение исходной информации в контекст определенной учебной задачи. Иногда этот анализ предполагает повторное чтение формулировки задания, так как теперь она воспринимается уже иначе, в определенной смысловой связи с изучением информационного источника (или источников);

- C - compress - «сжимаем» информачию, выделяем значимое. Исходные сведения, предоставляемые в информационных источниках, почти всегда избыточны, если рассматривать их с точки зрения выполнения конкретного задания. Важно уметь сократить объем анализируемой информации, «сжать» ее, выделив то, что требуется для выполнения задания «здесь и сейчас», и отбросив несущественное в данном контексте;

- $T$ - transform - преобразуем (в тот формат, который требуется в задании). Во многих заданиях исходную информацию нужно преобразовать и дать ответ в форме, отличной от первоначального представления. Например, на основании текста нужно заполнить таблицу. Или, найдя информацию на карте, составить корректное высказывание по текстовому шаблону. Эти действия, завершающие алгоритм выполнения задания, могут рассматриваться как расширительное толкование письма, то есть создания собственного информационного объекта.

Цепочка ReACT является универсальным алгоритмом выполнения заданий различного типа. Каждое из звеньев этой цепочки представляет собой последовательность более мелких операций - ЭУД. Если в результате тренинга ЭУД различного типа выполняются обучающимися без ошибок, это значит, что школьники готовы к самостоятельной работе с учебной информацией в логике ReACT. Другими словами, отладка когнитивных алгоритмов на уровне ЭУД приводит к формированию основ функциональной грамотности в трактовке А. А. Леонтьева.

\section{5. Учебные действия как рутина}

Для формирования устойчивых умений ребенок должен многократно выполнять учебные задания, построенные в логике ReACT. Такая цель сама по себе не выглядит привлекательной для детей. Нужно признать, что формирование основ функциональной грамотности - это не увлекательная игра, 
а рутина ${ }^{45}$ учебной деятельности. Убедить детей в необходимости ответственного выполнения этих повторяющихся действий - долг учителя. К каким бы творческим проявлениям ни лежала его душа, никакое серьезное занятие в рамках школьной программы не удастся превратить в свободное проявление предпочтений ребенка. Нельзя рассчитывать, что каждый мальчик или девочка будут охотно повторять упражнения. Но обойтись без этапа учебной рутины нельзя.

Тот, кто хочет стать, например, профессиональным пианистом, должен смириться с гаммами и подолгу играть этюды, чтобы «поставить технику». Без «техники» не обойтись ни в искусстве, ни в спорте, какой бы жанр или вид мы ни выбрали. Техника только гениям дается от природы, остальные должны пройти через долгие часы тренировок. И только потом, когда проблем с техникой уже не останется, начнется то самое творчество, ради которого приходится преодолевать трудности первого этапа.

Точно так же дело обстоит и с учебой. Наивно рассчитывать, что удастся обойтись без однообразных, но необходимых упражнений. Необходимых для того, чтобы сформировался набор навыков - та самая техника выполнения ЭУД. Чем раньше эти навыки появятся и будут доведены до автоматизма, тем меньше раздражения будут вызывать эти рутинные операции. А самое главное - можно будет двигаться вперед, туда, где и начинаются знание, творчество, соревнование, то есть к «эвристической» стадии. Там уже нельзя ограничиться универсальными алгоритмами типа ReACT. Когнитивная деятельность по-прежнему останется алгоритмической по своему характеру, но эти алгоритмы каждый человек отлаживает в процессе своего развития, который основывается на формальном обучении, но далеко выходит за его пределы. В терминах нейрофизиологии (по Р. Курцвейлу) для этого требуется, чтобы сформировался набор распознавателей шаблонов высокого уровня [Нейман]. А рутинный процесс отладки простых когнитивных алгоритмов это тот фундамент, на котором строится любой образовательный маршрут.

Формирование любого умения предполагает активную деятельность самого обучаемого. Когда класс по команде синхронно выполняет одни и те же задания, учителю трудно обеспечить рабочий ритм, подходящий в равной мере для всех учеников. Особенно заметно проявляются негативные аспекты фронтальной работы, когда учебный коллектив неоднороден по составу. Те, кто лучше подготовлен, быстро справляются с заданиями, а после этого или скучают без дела, или торопят учителя, вынуждая его двигаться дальше. Те, кто послабее, не могут действовать в комфортном для себя темпе, отстают от товарищей, раздражаются или, напротив, теряют интерес и впадают в апатию. В результате значительная часть класса обречена на неполноценное учение. По мере усложнения материала их отставание, которое началось в начальной школе, может стать необратимым. Учителям приходится учитывать наличие отстающих и приноравливаться к их возможностям, искусственно замедляя движение всего учебного коллектива.

Так проблема несформированности базовых умений приводит к снижению эффективности учебного процесса в целом. Поэтому индивидуальная работа каждого, постановка учебной техники у всех без исключения учеников

45 Термин «рутина» означает устойчивый порядок действий. Он применяется и в компьютерной литературе (computer routine - программная процедура, subroutine - подпрограмма). 
должны стать приоритетной задачей учителя начальной школы. Он должен найти способы увлечь детей этой рутинной работой, научить их учиться. Опыт подобного тренинга показывает, что основные риски потери мотивации проявляются на начальной стадии. Как только дети привыкают к самостоятельной работе с компьютером и ощущают привлекательность самооценки (с возможностью улучшить свои баллы за счет повторных попыток), их заинтересованность в результате не пропадает даже при отсутствии внешних стимулов (игра, соревнование и т. п.).

\section{6. Распределение субъектных ролей в процессе тренинга}

Регулярно повторяемые ЭУД, собираемые в цепочки типа ReACT и оперативно проверяемые компьютером, и являются основой тренинга — процесса отладки соответствующих когнитивных алгоритмов, в котором активную сознательную роль играет сам обучающийся.

Необходимость учебной рутины именно как «умения учиться» должна быть понятна самому ребенку. Не даст нужного эффекта выполнение технических заданий "для кого-то», при собственном равнодушном отношении к результату. С другой стороны, самостоятельно достичь целей тренинга большинство учащихся начальной школы не в состоянии. Следовательно, педагогическая задача требует наличия «партнера», который обнаружит неверные ответы, подаст сигнал о необходимости скорректировать свое поведение, поможет оценить собственные действия, подскажет, как найти допущенные ошибки. Таким партнером может быть взрослый (учитель, родитель, психолог и т. д.) или компьютер. Преимущества и ограничения обоих вариантов подробно обсуждаются в главе 3, посвященной анализу различных моделей управления учебным процессом с использованием цифровых технологий.

Индивидуальные практики, реализуемые в учебном коллективе, ставят перед учителем задачи организации параллельной самостоятельной работы группы учеников. «На уровне школы источником функциональной неграмотности может выступать отсутствие возможности со стороны учителей начальной и основной школы учитывать особенности каждого ученика» [Российская школа...]. Эта задача может оказаться непосильной, если не использовать возможности цифровых технологий. Функция взрослого заключается в том, чтобы правильно определить возможности каждого ребенка и оказать ему адресную помощь в переходе в зону ближайшего развития. А компьютерный интеллект приходит учителю на помощь, предоставляя в сжатом виде аналитику данных о когнитивном развитии его учеников, необходимую, чтобы правильно построить индивидуальные образовательные траектории. Но и сами ученики не являются в ходе тренинга пассивными исполнителями. Учитель анализирует данные и принимает решения, а ученик, следуя его рекомендациям, управляет своей работой, добиваясь через повторяющуюся деятельность стабильного выполнения ЭУД.

Чтобы компьютер мог включиться в образовательные отношения между учителем и его учениками, задания, которые предлагаются детям на этапе «отладки алгоритмов», должны соответствовать требованию однозначности оценивания. Если предполагается, что ответ может быть дан в свободной форме, то возникает проблема формальной оценки, которую дают 
выполненной работе разные субъекты. На «алгоритмической» стадии такая неоднозначность недопустима, потому что ребенок может потерять ориентир и в самооценке. Ему придется спрашивать мнение взрослого (учителя, родителя), которое может оказаться и запоздавшим, и необъективным. Это, в свою очередь, открывает возможности для произвольной интерпретации ребенком внешней оценки, а значит, и для «лукавства» в самооценке. Поэтому все задания индивидуального тренинга с самооценкой должны иметь формализованную процедуру проверки, доступную как человеку, так и компьютеру.

Изменение ролей учителя и ученика, связанное с появлением нового субъекта отношений - компьютера, важно и для формирования психологических установок ребенка. Можно отметить как минимум два важных обстоятельства:

- привыкнув к новой практике, ребенок начинает рассматривать компьютер как инструмент собственной деятельности. Обратная связь - сигнал о правильном или ошибочном действии - постепенно становится для него фактором самооценки. Поясним на примере. Когда на уроке физкультуры ученик бросает мяч в баскетбольное кольцо, он может сам оценить успешность действия, потому что видит результат. Точно так же о достижении цели в ходе действия, результат которого не столь очевиден, ученик судит по реакции компьютера. Компьютер как бы расширяет возможности непосредственного восприятия результата и тем самым включается в механизм самооценки и самообучения;

- реакция компьютера на учебное действие носит объективный характер. К сигналу обратной связи не примешиваются субъективные факторы, которые во многих случаях склонен учитывать учитель.

Таким образом, можно заключить, что в отладке когнитивных алгоритмов роли распределены между тремя субъектами образовательных отношений:

1) учитель - ставит образовательную задачу;

2) ученик - непосредственно отрабатывает те или иные умения;

3) компьютер - выступает как средство автоматического контроля результата и инструмент самооценки ученика.

\section{Выводы}

1. В условиях цифровой трансформации и сам процесс обучения, и взаимодействия между субъектами образовательных отношений становятся более формализованными. В едином цифровом стандарте должны сосуществовать взаимодействия «человек - человек» и «человек компьютер». Требуется достижение баланса между гуманитарной природой образовательной деятельности и алгоритмической четкостью при выполнении учебных действий в цифровой среде.

2. В рамках образовательного процесса на стадии цифровой трансформации должна увеличиваться доля учебных практик формального обучения, в которых развитие ребенка достигается за счет отладки когнитивных алгоритмов. На начальной стадии обучения эти алгоритмы имеют универсальный характер, так как на их основе строятся базовые навыки и умения. Задача педагога - добиться стабильного и по возможности безошибочного выполнения этих универсальных алгоритмов, представляющих собой цепочки ЭУД. 
3. Основы функциональной грамотности (по Леонтьеву) формируются на базе когнитивной цепочки ReACT, аналогичной по структуре алгоритмам «ввод - преобразование - вывод», характерным для компьютерных операций.

4. В начальной школе велика роль рутинных действий, так как в младших классах закладывается фундамент последующего результативного обучения, то есть умение учиться. Отладка когнитивных алгоритмов достигается в ходе индивидуального тренинга, где компьютер выступает одновременно как инструмент выполнения учебных действий и как источник обратной связи для обучающегося.

5. Успешное выполнение ЭУД, формирование основ функциональной грамотности в начальной школе дают возможность на следующей ступени обучения сместить баланс от «алгоритмической» составляющей к «эвристической».

\section{Литература}

1. Аллахвердов В. М. Сознание как парадокс. СПб. : ДНК, 2000.

2. Асмолов А. Г. Как проектировать универсальные учебные действия в начальной школе: от действия к мысли : пособие для учителя / А. Г. Асмолов, Г. В. Бурменская, И. А. Володарская [и др.] ; под ред. А. Г. Асмолова. М. : Просвещение, 2008.

3. Леонтьев А. А. От психологии чтения к психологии обучения чтению // Материалы 5-й Международной научно-практической конференции (26-28 марта 2001 г.) : в 2 ч. Ч. 1 / под ред. И. В. Усачевой. М., 2002.

4. Леонтьев А. А. Педагогика здравого смысла. Смысл, 2016.530 с.

5. Нейман Дж. фон. Вычислительная машина и мозг / Джон фон Нейман ; [пер. с англ. А. Чечиной]. M. : ACT, 2018. 192 C.

6. Российская школа: начало XXI века / С. Г. Косарецкий, К. А. Баранников, А. А. Беликов [и др.] ; под ред. С. Г. Косарецкого, И. Д. Фрумина ; Нац. исслед. ун-т «Высшая школа экономики», Ин-т образования. М. : Изд. дом Высшей школы экономики, 2019. 432 с. (Российское образование: достижения, вызовы, перспективы / науч. ред. Я. И. Кузьминов, И. Д. Фрумин) [Электронный pecypc].URL: https://ioe.hse.ru/data/2019/04/09/1176079128/Ros.shkola-text.pdf (дата обращения: 12.07.2021).

7. Рубинштейн С. Л. Основы общей психологии. М., 1989. Т. 1. С. 192-193.

8. Талызина Н. Ф. Педагогическая психология : учеб. пособие для студ. сред. пед. учеб. заведений. М. : Академия, 1998. 288 c.

9. Уваров А. Ю. Цифровая трансформация и сценарии развития общего образования / А. Ю. Уваров ; Национальный исследовательский университет «Высшая школа экономики», Институт образования. М. : НИУ ВШЭ, 2020. 108 с. (Современная аналитика образования. № 16(46)). 


\section{ГЛАВА 9}

\section{Пилотный эксперимент}

Чтобы оценить возможные эффекты цифровой трансформации, необходимо подвергнуть исследованию отношения, возникающие в учебном процессе, переведенном на соответствующую технологическую основу. Сегодняшние условия обучения в массовой школе не отвечают требованиям цифровизации ни в методическом, ни в инструментальном обеспечении, поэтому исследование не может быть построено на изучении существующих учебных практик. Для проведения экспериментальной части исследования необходимо создать условия, в которых систематические учебные действия, управленческие решения и коммуникации субъектов учебного процесса будут фиксироваться в цифровом формате.

В рамках пилотного эксперимента все учебные действия обучающихся, а также действия учителей и администраторов в рамках педагогического сопровождения и реакции родителей, наблюдающих за работой детей, служат организационной и информационной основой для анализа развития образовательных отношений в условиях цифровизации. Принципиальным преимуществом цифровых технологий является возможность фиксации событий, происходящих в ходе учебного процесса, и сохранения их для последующего анализа и интерпретации. В этой связи ключевым технологическим решением, используемым в исследовании, является механизм сохранения действий различных субъектов в виде цифрового следа. В современной информационной среде понятие «цифровой след», как правило, трактуется очень широко, например как фиксация истории любых действий пользователей Интернета. В такой трактовке термин используется, в частности, в системах, определяющих персональные предпочтения пользователей на основе контент-анализа их запросов к поисковым системам. В контексте пилотного эксперимента это понятие сужается и ограничивается только действиями на специализированной цифровой платформе, имеющими отношение к выполнению конкретных учебных задач и предусмотренными субъектными ролями обучающихся и взрослых, наблюдающих за процессом и осуществляющих педагогическое сопровождение.

При разработке методологии педагогического эксперимента принимались во внимание следующие требования:

- эксперимент должен проводиться в условиях массовой школы, а не на специально подобранных инновационных площадках, имеющих большой опыт работы с цифровыми технологиями. От участников не требуется предварительной подготовки, единственное условие для образовательных организаций - это готовность проводить регулярные занятия в начальной школе с использованием цифровой платформы, обеспечив каждому ученику доступ в Интернет; 
- исследование отношений должно строиться вокруг регулярной учебной деятельности обучающихся в начальной школе, проводимой с использованием цифровых инструментов, доступных различным субъектам образовательных отношений;

- должна быть предусмотрена возможность сбора и фиксации сведений о действиях субъектов в цифровой среде для накопления и использования «больших данных».

Целью пилотного эксперимента является качественная, а по возможности и количественная оценка значимости факторов, влияющих на развитие межсубъектных отношений в начальной школе в условиях цифровой трансформации. К этим факторам мы относим как уровень сформированности необходимых навыков и умений у обучающихся, так и способность школьных педагогов и администраторов использовать цифровые инструменты для организации учебного процесса. Важной составляющей эксперимента было изучение вовлеченности родителей обучающихся в учебные действия, проводимые в рамках эксперимента.

Таким образом, в экспериментальной части исследования была поставлена задача определить готовность всех участников образовательных отношений к выполнению своих субъектных ролей в цифровой среде, в частности:

- готовность обучающихся к самостоятельному выполнению учебных действий в цифровых форматах;

- готовность учителей к использованию инструментов цифровой платформы для повышения результативности обучения за счет выстраивания индивидуальных и групповых учебных траекторий;

- готовность школьных администраторов к использованию данных мониторинга, собираемых на цифровой платформе, для корректировки учебного процесса на уровне образовательной организации;

- характер отношения родителей обучающихся к цифровым практикам, их готовность к использованию данных, фиксируемых на цифровых платформах, для выстраивания со школой продуктивного диалога для повышения результативности обучения их детей.

\section{1. Организация учебных действий}

Для создания необходимых условий школам, участвующим в эксперименте, была предложена специально разработанная организационная модель, предполагающая проведение регулярных учебных действий на цифровой платформе. В качестве формы учебных действий был выбран индивидуальный компьютерный тренинг. Педагогическое обоснование этой цифровой учебной практики (далее - ЦУП) дано в главе 8 монографии. Выбор именно этой практики обусловлен тем, что алгоритмический характер тренинга позволяет получить цифровой след, удобный для анализа, так как все задания построены на последовательности элементарных учебных действий (ЭУД), выстроенных в логике ReACT. Интерпретация данных осуществляется с использованием синдрома ошибки, что позволяет учителю найти причины неверных действий и сразу же предпринять конкретные шаги к исправлению ситуации. Полученные сведения доступны не только педагогам, но и родителям и могут послужить основой для принятия согласованных управленческих решений. Таким образом, методология эксперимента предусматривает 
не только непосредственное изучение данных, фиксируемых в виде цифрового следа, но и анализ реакций различных субъектов на эти данные.

Организационная модель, предложенная школам, основана на следующих принципах:

- Ц ЦУП дополняет регулярный учебный процесс, а не замещает его существенные элементы, чтобы исследователь мог выделить эффекты именно этой практики из общего фона образовательной деятельности школы;

- цели и средства ЦУП интуитивно понятны как обучающимся, так и взрослым субъектам образовательного процесса;

- Ц ЦУП обеспечивает возможность оценивания как самого учебного процесса, так и его результатов для конкретных обучающихся;

- Ц ЦУП должна быть технологичной и тиражируемой, то есть должно быть обеспечено ее распространение в любых образовательных организациях, имеющих доступ в Интернет.

Технологической основой для цифрового взаимодействия различных субъектов в современных условиях является образовательная платформа. Одним из ключевых признаков цифровой платформы является «алгоритмизация взаимодействия участников платформы: процедуры взаимодействия участников детерминированы и реализуются в рамках установленного алгоритма» ${ }^{46}$. Подобный детерминированный характер взаимодействий наилучшим образом подходит для целей исследования, так как дает четко структурированный цифровой след.

В качестве инструментального решения для проведения исследования были использованы сервисы специализированной цифровой платформы для начальной школы (далее - ЦПНШ) «Учим учиться» ${ }^{47}$. Практическая реализация изложенной выше концепции тренинга позволила развернуть на платформе онлайн-сервисы, предназначенные для различных субъектов учебного процесса. Основное назначение этих сервисов - содействие подготовке всех участников образовательных отношений (школьников и их родителей, учителей, представителей школьной администрации) к цифровой трансформации системы образования [Кондратьева, Рубашкин].

ЦПНШ «Учим учиться» прошла широкую апробацию: в период с сентября 2018 по май 2020 г. на платформе работали свыше 2500 школьников из различных регионов России. Подробные сведения о возможностях платформы и проектах, проводимых на ее основе, размещены на сайте учим-учиться.рф.

Опыт проведенной апробации позволил начать экспериментальную работу сразу в нескольких десятках школ, работающих в различных социальных контекстах: от мегаполиса до малых городов и населенных пунктов в сельской местности. В пилотном эксперименте, начавшемся в 2020/2021 учебном году, приняли участие школы пяти регионов Северо-Запада России. Одной из задач эксперимента была отработка различных механизмов дистанционного взаимодействия между командой проекта и образовательными

46 Проект «Подходы к определению и типизации цифровых платформ» // Цифровая экономика [Электронный ресурc]. URL: https://files.data-economy.ru/digital_platforms_project.pdf (дата обращения: 12.07.2021).

47 Научно-педагогическое обоснование инструментария этой платформы было выполнено разработчиком (ООО «Студия „Март“», Санкт-Петербург) в рамках НИОКР «Обучающая система для формирования у школьников метапредметных компетенций» при поддержке Фонда содействия инновациям (2015-2016 гг.). Регистрационный номер ИКБС ААA-A17-217061440054-6 от 14.06.2017 г. 
организациями. В связи с этим часть школ были объединены в кластеры с единым организационным и методическим руководством. Примерами кластеров являются школы Псковской области (при участии Псковского областного института повышения квалификации работников образования) и школы двух районов Санкт-Петербурга (при участии районных информационно-методических центров). Остальные школы взаимодействовали с командой проекта напрямую. Региональное представительство отражено в табл. 17.

Таблица 17

\section{Состав участников эксперимента}

\begin{tabular}{|l|c|c|c|}
\hline \multicolumn{1}{|c|}{ Регион эксперимента } & Количество школ, ед. & Количество классов, ед. & Количество учеников, чел. \\
\hline Санкт-Петербург & 16 & 19 & 532 \\
\hline Ленинградская область & 1 & 9 & 260 \\
\hline Псковская область & 11 & 12 & 327 \\
\hline Калининградская область & 1 & 8 & 253 \\
\hline Республика Карелия & 1 & 2 & 55 \\
\hline Всего & 30 & 50 & 1427 \\
\hline
\end{tabular}

Программа пилотного эксперимента состояла из трех этапов. Первые два этапа выполнялись учащимися третьих классов в 2020/2021 учебном году ${ }^{48}$. Третий этап будет выполняться этими же школьниками (после перехода в четвертый класс) в 2021/2022 учебном году.

Задачей первого этапа было включение компьютерного тренинга в учебный процесс школ, а также определение стартовых позиций обучающихся и педагогов в плане их готовности к выполнению своих субъектных ролей:

- ученикам на этом этапе были предложены задания так называемого диагностического модуля для выявления у них дефицитов цифровых общеучебных умений, препятствующих результативному обучению;

- педагоги при поддержке команды проекта должны были освоить инструменты и сервисы ЦПНШ, предназначенные для педагогического сопровождения тренинга;

- важной организационной задачей было обеспечить контроль за действиями учителей со стороны администрации в лице школьного координатора;

- временна́я граница между первым и вторым этапами была достаточно условной. Отдельные школы и даже отдельные классы переходили ко второму этапу в разное время — по мере завершения обучающимися диагностического модуля.

Основным содержанием второго этапа была отработка продвижения обучающихся по персонализированным траекториям, построенным с учетом показателей диагностики (то есть первого этапа эксперимента). Главной задачей команды проекта была координация усилий взрослых субъектов учебного процесса, нацеленная на достижение каждым учеником максимального индивидуального прогресса.

В рамках третьего этапа классам будут предложены тренинговые программы, нацеленные на подготовку к основной школе. Предполагается, что

48 Данные и первичная аналитика по первым двум этапам пилотного эксперимента предоставлены Е. Д. Рубашкиным, аналитиком ООО «Студия „Март“». 
опыт выполнения субъектных ролей, полученный в течение учебного года, поможет повысить эффективность учебного процесса, в частности за счет достигнутой в ходе тренинга компенсации индивидуальных и групповых дефицитов общеучебных умений и уменьшения неоднородности ученического коллектива.

Завершая описание организационной модели, необходимо отметить, что в ходе выполнения первого и второго этапов команда проекта активно взаимодействовала со всеми школами в течение всего учебного года, обеспечивая как методическое, так и техническое сопровождение. Вместе с тем сама идея исследования предполагала, что в ходе эксперимента могут быть выявлены различные отклонения действий участников от рекомендованных образцов. В таких случаях проектная команда фиксировала эти проявления, но не стремилась оказать административное воздействие на своих партнеров.

\section{2. Информационный тренинг. Методология эксперимента и субъектные роли}

В качестве дидактической основы для разработки тренинговых заданий была использована инновационная учебная практика - информационный тренинг, разработанная авторами для формирования у школьников учебноинформационных умений [Воровщиков] как основы достижения метапредметных и личностных результатов. Образовательная задача тренинга - не проверка знаний, полученных в учебном процессе, а тренировка способности выполнять требуемые действия с учебной информацией, представленной в различных медийных форматах. Как правило, все необходимые для выполнения сведения содержатся внутри задания. Тренинговые программы представляют собой последовательность разнотипных и разноуровневых заданий, каждое из которых предполагает необходимость выполнения трех ключевых действий: считывание информации с источника, анализ и сжатие информации (выделение существенного в данном контексте), преобразование и вывод ответа в требуемом формате ${ }^{49}$.

Практика информационного тренинга может применяться на разных ступенях обучения, но наиболее полно она соответствует потребностям начальной школы, так как именно в этом возрасте метапредметные результаты имеют приоритетную значимость [Любимов]. Задания способствуют развитию умений выполнять вне предметного контекста типовые действия с учебной информацией, представленной в различных мультимедийных форматах. Тренинг основан на многократном повторении (в различных комбинациях) цепочек ЭУД. Программные сервисы ЦПНШ фиксируют и классифицируют допущенные при выполнении некорректные действия, что позволяет на основе анализа синдрома ошибки выявлять у каждого ученика дефициты умений и компенсировать их.

Дидактические материалы информационного тренинга были разработаны И. Н. Кондратьевой с учетом следующих требований:

1) задания носят не проверочный, а формирующий характер. Вследствие этого в качестве исходной учащимся может быть предложена информация, относящаяся к учебной теме, которая ими пока не изучена:

\footnotetext{
${ }^{49}$ См. главу 8.
} 
в этой информации нужно разобраться самостоятельно с учетом конкретной формулировки задания;

2) для формирования устойчивых умений требуется многократное выполнение однотипных действий (рутинизация обучения в логике отладки когнитивных алгоритмов). Вместе с тем эти операции не должны повторяться в точности одинаково, так как механическим повторением можно сформировать только навыки. Требуется добиться баланса между однотипностью выполняемых ЭУД и разнообразием конкретных заданий, отличающихся друг от друга формулировкой вопроса, формой представления исходной информации, количественными значениями параметров, форматом представления ответа и т. Д.;

3) для целей диагностики дефицитов (первый этап) всем обучающимся должны быть предложены одинаковые задания, чтобы иметь возможность оценить стартовые позиции каждого ученика относительно статистической нормы, полученной для всей генеральной совокупности пользователей, выполнявших задания диагностического модуля 50 ;

4) для дальнейшего прохождения тренинга (второй этап) обучающимся предлагаются три различных по сложности модуля. Выбор модуля для конкретного ученика определяется его результатами, показанными в ходе диагностики. Модули имеют одинаковую внутреннюю структуру, чтобы ученики, идущие по разноуровневым траекториям, выполняли аналогичные задания на своем уровне сложности. Это позволяет выстраивать ступенчатые траектории, при которых ученик, успешно выполнивший свой модуль, может подняться на более высокий уровень.

Информационный тренинг базируется на персонализированной модели: ученику в личном кабинете предлагается последовательность заданий для самостоятельного выполнения в цифровой форме. Практика использует организационную модель, в рамках которой каждый ученик работает в составе класса под руководством преподавателя. Все обучающиеся, входящие в группу, выполняют один и тот же объем учебных действий, но каждый из них работает по индивидуальному временному графику в наиболее комфортном для себя темпе.

Все учебные действия каждого ученика и их результаты автоматически фиксируются на ЦПНШ, правильность выполнения заданий проверяется самой программой (плеером), с помощью которой задания выполняются. Плеер определяет, правильно ли выполнено задание, результат проверки сразу же сообщается ученику, который имеет возможность (в случае выявленных ошибочных действий) самостоятельно найти и исправить допущенные ошибки.

Учителю предоставляются инструменты для наблюдения за учебной работой учеников в онлайн-режиме; при необходимости он может скорректировать поведение каждого ученика в реальном времени. Запись учебных действий каждого ребенка доступна его родителям, учителю, проводящему тренинг (по всему классу), а также другим представителям данной образовательной организации.

Как отмечено выше, в пилотном эксперименте термин «цифровой след» ограничивается только действиями с использованием сервисов ЦПНШ. В это понятие, таким образом, включаются и собственно фиксация хода и результата

50 В настоящее время статистические данные ЦПНШ строятся на основании результатов почти 3500 учеников. 
учебных действий обучающихся, и назначение учителями очередных блоков заданий, и посещение личных кабинетов родителями, и коммуникации, возникающие между педагогами и родителями с использованием функционала их личных кабинетов.

Одной из ключевых гипотез проводимого исследования является представление о том, что при использовании персонализированной модели обучения успешность ребенка во многом зависит от действий окружающих его взрослых. Даже в ходе самостоятельных учебных действий многим детям требуется помощь педагогов или родителей, чтобы справиться с возникающими трудностями. В соответствии с концепцией Л. С. Выготского [Выготский] ребенок нуждается в поддержке взрослого, чтобы перейти в зону ближайшего развития. Эта помощь также должна быть персонализированной, то есть основываться на объективной оценке возможностей конкретного ребенка. Соответствующую информацию для этой оценки различные субъекты могут получить, имея доступ к цифровому следу (рис. 36). Учитель, непосредственно ведущий обучение, другие специалисты сферы образования (педагоги, психологи) и родители составляют микрогруппу, имеющую доступ к одним и тем же объективным данным, и могут на основе их анализа и интерпретации строить свое взаимодействие в интересах ребенка.

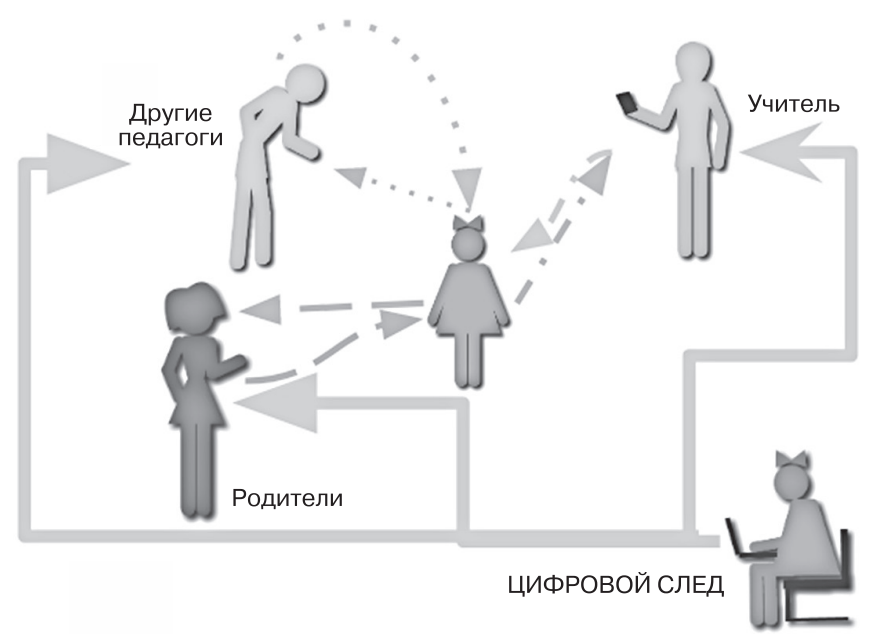

Puc. 36. Цифровой след учебных действий как основа взаимодействия субъектов

Задача моделирования образовательных отношений решается в пилотном эксперименте за счет организации взаимодействия различных субъектов на ЦПНШ. Ученики, учителя, родители, школьные координаторы получают свои личные кабинеты. Все производимые в ходе учебной практики действия различных субъектов фиксируются для последующего анализа экспертной системой платформы. Первичные результаты аналитики автоматически направляются в личные кабинеты педагогов и родителей (с учетом их прав доступа).

В рамках эксперимента отрабатывается также и взаимодействие между учителем и представителями администрации школы. В процессе занятий на ЦПНШ собирается информация, которая позволяет администрации школы оценить готовность учителя работать в рамках регулярной цифровой практики, интерпретировать текущие образовательные результаты своих учеников, 
корректировать индивидуальные и групповые образовательные маршруты. Представитель администрации школы (координатор) получает на цифровой платформе роль наблюдателя, что дает ему информацию о действиях всех учащихся данной школы и обо всех учителях, ведущих тренинг.

Онлайн-сервисы ЦПНШ поддерживают действия различных субъектов образовательных отношений, возникающие в ходе регулярных занятий с использованием сервисов цифровой платформы. Описания ролевых функций представлены в табл. 18.

Таблича 18

\section{Роли, поддерживаемые ЦПНШ с предоставлением личных кабинетов}

\begin{tabular}{|l|l|}
\hline \multicolumn{1}{|c|}{ Субъектная роль } & \multicolumn{1}{c|}{ Действия } \\
\hline Ученик & $\begin{array}{l}\text { Выполняет учебные задания, принимает обратную связь от компьютера, исправля- } \\
\text { ет ошибки, принимает самостоятельное решение о целесообразности повторного } \\
\text { выполнения заданий }\end{array}$ \\
\hline Учитель & $\begin{array}{l}\text { Управляет темпом назначения очередных блоков заданий конкретному ученику } \\
\text { или группе, сопровождает процесс выполнения, анализирует текущие сведения об } \\
\text { учебных действиях, предоставляемые цПНШ, оценивает результаты, корректирует } \\
\text { индивидуальные и групповые траектории, при необходимости вступает в комму- } \\
\text { никации с родителями учеников }\end{array}$ \\
\hline $\begin{array}{l}\text { Координатор } \\
\text { (представитель } \\
\text { администрации школы) }\end{array}$ & $\begin{array}{l}\text { Наблюдает за процессом выполнения заданий и работой учителя, корректирует ор- } \\
\text { ганизацию учебных действий, оценивает групповые результаты учебных действий, } \\
\text { при необходимости - по групповым результатам, фиксируемым на ЦПнш, }- \\
\text { корректирует учебные планы }\end{array}$ \\
\hline Родитель & $\begin{array}{l}\text { Наблюдает за работой своего ребенка, получает сведения о текущих действиях и } \\
\text { результатах аналитики, взаимодействует с учителем и координатором по поводу } \\
\text { организации тренинга, оценки результатов и корректировки индивидуальной тра- } \\
\text { ектории }\end{array}$ \\
\hline
\end{tabular}

Все перечисленные в табл. 18 субъекты, выполняя свои ролевые функции, оставляют «цифровой след». Рассмотрим, какие сведения об их действиях собираются на ЦПНШ.

Ученик: в процессе выполнения каждого задания формируется подробная запись всех выполненных ЭУД - трек задания, который становится доступным учителю и родителю сразу после выполнения. На основе анализа треков экспертная система рассчитывает значения индикаторов, характеризующих умение ребенка работать с учебной информацией и его поведение в процессе тренинга.

По мере увеличения числа школьников, работающих на ЦПНШ, возникает эффект накопления «больших данных», на фоне которых анализируются характеристики конкретного ученика.

Учитель: на ЦПНШ фиксируются график проведения занятий и посещаемость; динамика назначения конкретному учащемуся очередных блоков заданий, частота заходов в свой личный кабинет для отслеживания хода тренинга; наличие реакций на сообщения экспертной системы платформы о проблемах в действиях учащегося, коммуникации с родителями и консультантами проекта по поводу того или иного ученика.

Школьный координатор: фиксируется частота заходов в личный кабинет, а также (опосредованно) результаты коррекции хода образовательного процесса (в части изменения поведения учителя).

Если несколько школ объединены в кластер, то Координатор кластера обеспечивает общее организационное и методическое руководство, 
проведение рабочих совещаний, вебинаров и других мероприятий, связанных с организацией тренинга, анализом собранных данных и принятием организационных решений. Действия координатора кластера на платформе не фиксируются и не анализируются.

Поведение Родителя характеризуется регулярностью посещения личного кабинета, количеством обращений к учителю и консультанту.

Кроме перечисленных выше субъектных ролей, относящихся к образовательным организациям - участникам эксперимента, ЦПНШ поддерживает экспертные роли (супервизор, аналитик, консультант), отвечающие за анализ и систематизацию данных, собираемых на платформе (по всем участникам тренинга и всем образовательным организациям). Эксперты участвуют в психолого-педагогическом сопровождении тренинга, взаимодействуя с различными субъектами учебного процесса.

\section{3. Цифровой след ученика как объект исследования}

В ходе уже завершившихся двух этапов обучающиеся выполняли задания диагностического и тренингового модулей, а педагоги и родители осуществляли наблюдение и педагогическое сопровождение учебных действий.

Диагностический модуль содержит 21 задание, в ходе которых нужно выполнить 297 различных ЭУД. Как правило, на выполнение заданий тренинга отводится один учебный час в неделю. Образовательные организации, работающие с ЦПНШ, сами выбирают организационную форму включения тренинга в учебный процесс. Большинство школ проводили диагностические процедуры в рамках внеурочных занятий, но есть примеры вынесения информационного тренинга за рамки формального обучения (в том числе проведение занятий в удаленном режиме, из дома).

В соответствии с логикой персонализированного обучения темп прохождения тренингового модуля не регламентируется. Скорость выполнения заданий не считается значимым для оценивания фактором. Опыт широкой апробации показывает, что на адаптацию к новой ЦУП у школ уходит примерно от 3 до 6 занятий, после чего в среднем за академический час дети выполняют по 3-4 задания. В табл. 19 представлены данные о динамике выполнения участниками эксперимента диагностических процедур (в списках классов значились 1427 учеников, из которых к выполнению заданий приступил 1321 ученик, полностью выполнили все задания модуля 1178 учеников, то есть порядка 90\%).

Таблица 19

Время, потраченное учащимися на выполнение заданий диагностического модуля

\begin{tabular}{|c|c|c|}
\hline \multirow{2}{*}{ Период выполнения, недель } & \multicolumn{2}{|c|}{ Количество учащихся } \\
\cline { 2 - 3 } & Чел. & $\%$ \\
\hline $1-4$ & 147 & 12 \\
\hline $5-8$ & 256 & 22 \\
\hline $9-13$ & 432 & 37 \\
\hline Больше 13 & 343 & 29 \\
\hline
\end{tabular}


Из табл. 19 видно, что примерно $2 / 3$ учащихся уложились в отведенное на первый этап время (октябрь — декабрь 2020 г.). Большая часть из оставшихся завершили выполнение модуля до конца февраля 2021 г. По результатам фиксации и анализа действий участников образовательных отношений можно предположить, что эта задержка в значительной степени была вызвана недостатками в организации занятий со стороны учителей (см. ниже).

В результате проведения диагностических процедур и последующей статистической обработки данных составляются так называемые диагностические карты, в которых определяются стартовые позиции каждого ученика для последующего тренинга на втором этапе эксперимента.

Основное содержание первичной аналитики заключается в анализе характера ошибок, допущенных учениками в ходе выполнения заданий. Каждое ошибочное действие экспертная система относит к определенному типу ошибки (см. ниже описание показателей диагностической карты). Например, в случае фиксации неверного результата при выполнении арифметического действия к разным типам будут отнесены ошибки извлечения исходных данных (в частности, из-за невнимательного прочтения условия) и собственно ошибки вычислительной операции. Аналогично, к разным типам относятся содержательно неверные ответы и ответы, в которых обнаружена ошибка, допущенная при списывании. Анализируя треки выполненных заданий, экспертная система подсчитывает количество ошибок каждого типа и сводит результаты в диагностическую карту.

Основная часть диагностической карты, на основе которой определяются стартовые позиции учащихся, отражает измерения по 13 индикаторам, которые делятся на три группы:

- по формату источника исходной информации - определяется уровень умений учащегося извлекать информацию из учебных материалов, представленных в разных форматах: 1) текста; 2) таблицы; 3) изображения; 4) нескольких источников информации одновременно; а также 5) использование собственных данных, которые были получены учеником самостоятельно на предыдущих шагах выполнения задания;

- по виду действий с информацией - проверяется сформированность умений: 1) производить вычислительные операции; 2) выполнять операции сравнения; 3) делать логические выводы; а также 4) способность внимательно и без ошибок переписать представленный в исходном источнике текст; 5) общий кругозор - использование сведений, не представленных в явном виде в задании;

- по формату данных - оценивается корректность трансформации исходных данных: 1) из числовой формы в числовую; 2) из текстовой формы в текстовую; 3) их текстовой формы в числовую и наоборот.

На рис. 37 представлен пример визуализации значений перечисленных выше индикаторов на фоне статистических данных по генеральной совокупности всех школьников, выполнявших задания диагностического модуля. Жирной точкой на столбцах диаграммы отображаются значения индикаторов для данного ученика. Средняя зона столбца соответствует «норме»диапазону значений, близких к показателям медианного ученика, верхняя зона - существенно выше «нормы», нижняя - существенно ниже. На рисунке видно, что по большинству показателей значения данного ученика близки к медианным, так как точки находятся или в средней зоне, или близко к ее границам. Несколько индикаторов, попавших в верхнюю зону, не меняют 


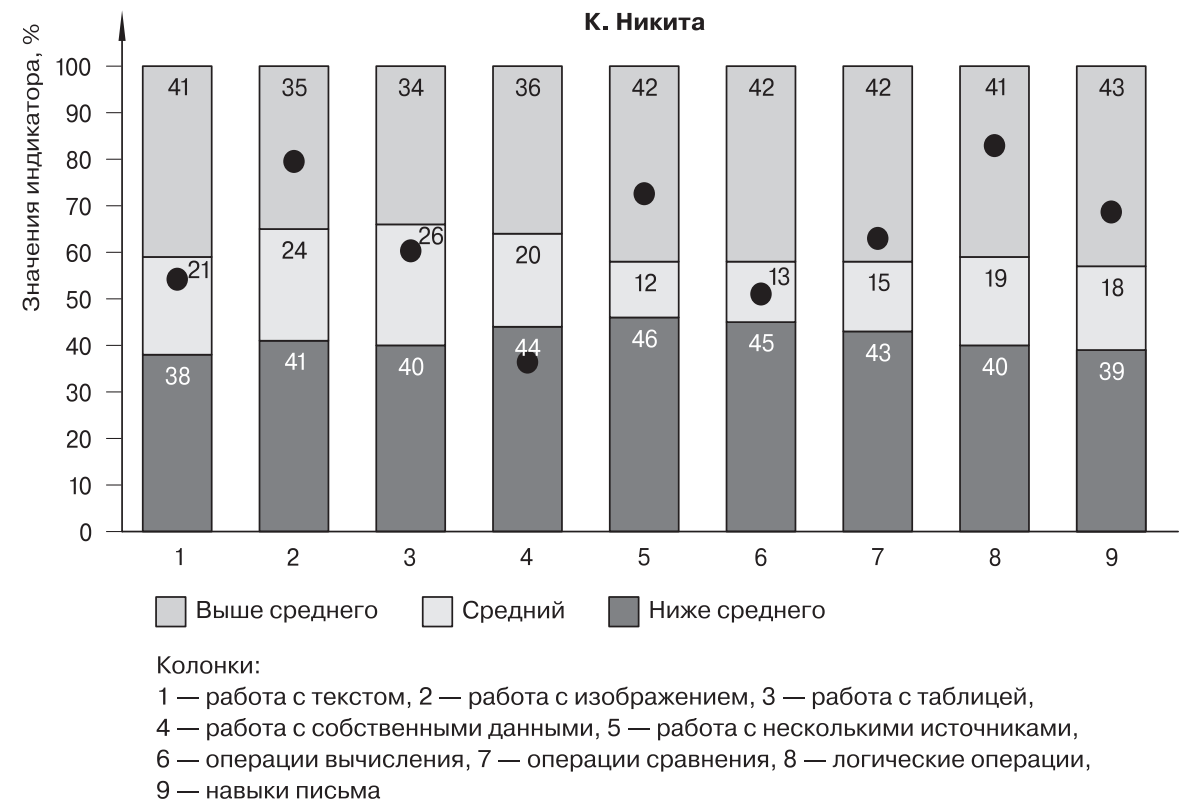

Рис. 37. Фрагмент диагностической карты учащегося

общей характеристики данного ученика. Хотя существенных дефицитов не обнаружено, умения неустойчивы, рекомендуется продолжение тренинга на среднем уровне для достижения стабильных результатов.

В диагностической карте ученика также отображаются следующие сведения:

- количество ошибок, которые сделал ученик при прохождении диагностики: общее и по типам действий (выбор ответа из предложенных, вписывание ответа в заданную цепочку рассуждений, свободный ответ на заданный вопрос);

- количество попыток, которые в среднем затрачивает учащийся на поиск и исправление сделанных ошибок (с первой попытки, со второй или правильный ответ не был найден);

- количество позиций, где учащийся и не пытался найти правильное решение, что указывает на дефицит мотивации.

Эти сведения важны для оценки личностных характеристик. Исследование закономерностей их проявления в зависимости от отношений «ученик учитель» будет предпринято на третьем этапе эксперимента.

На втором этапе каждому ученику была рекомендована одна из трех возможных траекторий тренинга: компенсирующая (К), тренировочная (Т) или развивающая (Р). Задания тренинговых модулей К, Т, Р построены на одних и тех же ЭУД и аналогичных информационных источниках, но тексты и вопросы в разных модулях предлагаются разной сложности.

Выполнение заданий модуля К способствует частичному или практически полному устранению выявленных дефицитов и достижению индивидуального прогресса по большинству индикаторов. Достижение прогресса при выполнении заданий компенсирующего характера позволяет выровнять учебный коллектив по сформированности учебно-информационных умений. Это 
способствует повышению результативности обучения и вне рамок ЦУП, на традиционных уроках.

Задания модуля Т помогают добиться стабильных метапредметных результатов и/или частичного устранения отдельных дефицитов (если таковые были выявлены).

Задания модуля Р предоставляют обучающимся возможность перейти к восприятию более сложных информационных источников, предполагающих необходимость более тщательного предварительного анализа предлагаемых сведений.

На рис. 38 представлено фактическое распределение учащихся, выполнивших все задания диагностического модуля, по уровням сложности назначенных им на втором этапе тренировочных модулей.

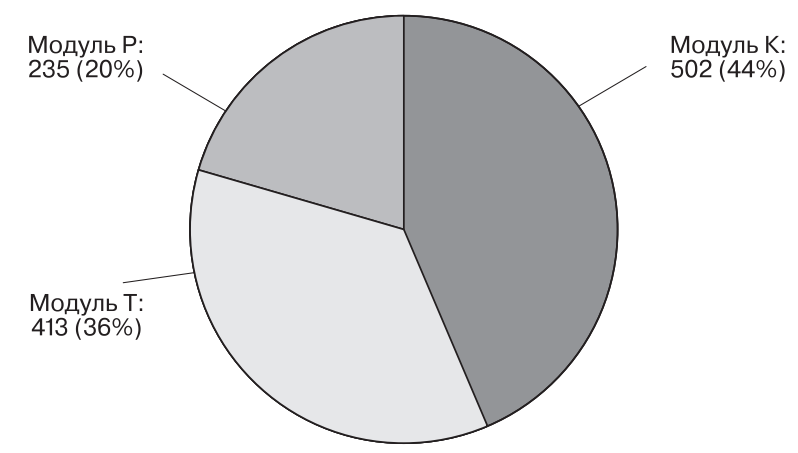

Рис. 38. Распределение участников эксперимента по уровням тренинговых модулей

Экспертная система предлагала рекомендуемый вариант уровня назначаемых модулей, но выбор траектории для каждого ребенка оставался за педагогами школы. В табл. 20 представлены данные о выполнении заданий второго этапа эксперимента на конец учебного года.

Таблица 20

Количество учащихся, выполнивших тренировочные модули

\begin{tabular}{|l|c|c|c|}
\hline \multirow{2}{*}{ Модуль } & \multirow{2}{*}{ Назначено, чел. } & \multicolumn{2}{|c|}{ Выполнено } \\
\cline { 3 - 4 } & & Чел. & $\%$ \\
\hline К (компенсация) & 502 & 365 & 73 \\
\hline Т (тренинг) & 413 & 328 & 79 \\
\hline Р (развитие) & 235 & 179 & 76 \\
\hline
\end{tabular}

Отметим, что на втором этапе многие ученики выполняли задания не только назначенного им уровня, но и - после выполнения заданий в полном объеме - переходили (по собственной инициативе, но с разрешения учителя) на более высокую траекторию. Нередки случаи, когда наиболее мотивированным ученикам удавалось пройти за отведенное на тренинг время все три уровня: от компенсирующего до развивающего.

В табл. 21 представлены данные выполнения заданий тренировочных модулей (Т) учащимися, которые начали второй этап проекта с компенсирующего модуля (K). 
Начало второго этапа: прохождение модулей учащимися, изначально получившими задания модуля K

\begin{tabular}{|l|c|c|c|c|}
\hline \multicolumn{1}{|c|}{} & \multicolumn{4}{|c|}{ Выполненные модули } \\
\cline { 2 - 5 } & Только K & $\mathbf{K , ~ T}$ & $\mathbf{K , ~ T , ~ P ~}$ & $\mathbf{K , ~ T , ~ P , ~ P + * ~}$ \\
\hline Количество учеников, чел. & 295 & 50 & 16 & 4 \\
\hline $\begin{array}{l}\text { Доля от общего числа учащихся, полу- } \\
\text { чивших задания модуля К, \% }\end{array}$ & 81 & 14 & 4 & 1 \\
\hline
\end{tabular}

* Р+ - дополнительный модуль уровня «Развитие». Он доступен тем, кто полностью выполнил модуль Р.

Из табл. 21 видно, что примерно 20\% учеников выполнили не только изначально назначенный им модуль К, но и еще как минимум один модуль. Следует также отметить. что большинство учеников по мере перехода с уровня на уровень показывают улучшение результатов (личный прогресс), несмотря на усложнение условий заданий.

По результатам прохождения учащимися тренинговых модулей, на основании анализа цифрового следа был определен индивидуальный прогресс каждого ученика относительно собственной стартовой позиции (данные диагностической карты). Здесь наибольший интерес представляют сведения об учащихся, выполнявших задания компенсирующего характера (модуля К), так как можно предположить, что именно их прогресс позволит сделать учебный коллектив более ровным по уровню владения метапредметными умениями, и это будет способствовать более эффективному обучению в рамках регулярных занятий.

На рис. 39 представлены данные достижения учащимися совокупного прогресса по всем 13 измеряемым индикаторам. На диаграмме видно, что больше половины участников достигли прогресса более чем по 8 индикаторам из 13, что может свидетельствовать как о проявленной самими учащимися мотивации, так и о положительном результате усилий, затраченных взрослыми участниками образовательных отношений.

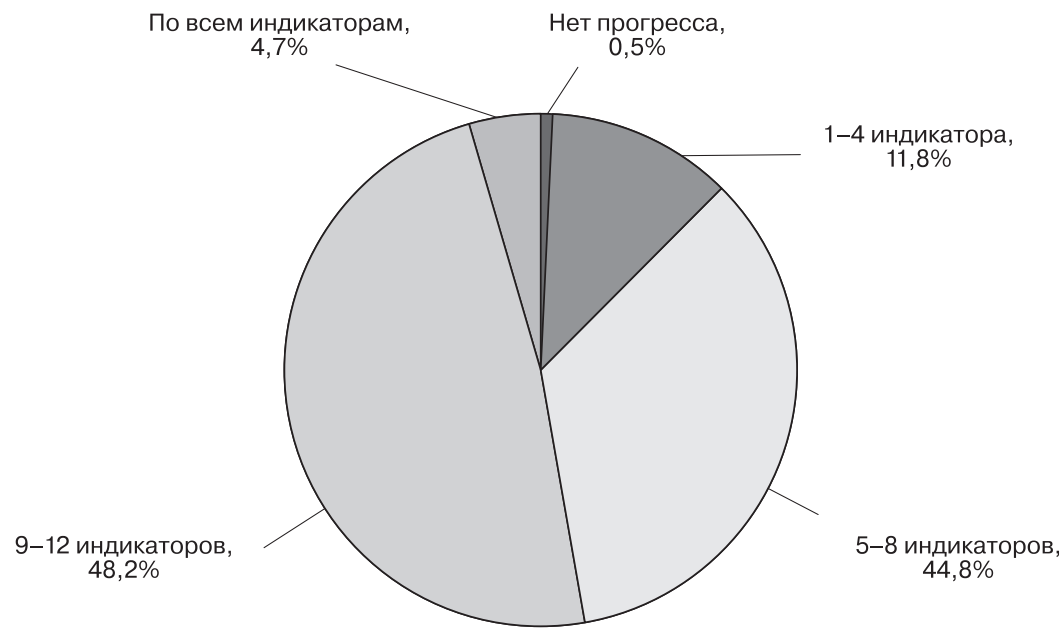

Рис. 39. Распределение участников эксперимента по уровням прогресса 


\section{4. Инструменты учителя: оперативное управление учебной практикой}

Успешность прохождения информационного тренинга обучающимися в значительной степени зависит от педагогического сопровождения. Для выстраивания результативных отношений «учитель - ученик» в персонализированной модели обучения на основе объективных данных о деятельности обучающегося, предоставляемых ЦПНШ, предлагаются различные инструменты для оперативного наблюдения за ходом тренинга как отдельного ученика, так и класса в целом.

Для учителя, ведущего тренинг, основным инструментом является электронный журнал класса (рис. 40). В своем личном кабинете он может видеть результат выполнения очередного задания сразу же после его завершения. В этой матрице строка соответствует ученику, колонка - конкретному заданию тренинговой программы. В каждой ячейке содержится балльная оценка, выставленная компьютером на основе подсчета допущенных учеником ошибок. Для удобства восприятия ячейки окрашены в разные цвета: зеленый цвет ячейки соответствует хорошему или отличному выполнению задания (разница передается оттенком цвета); желтый - удовлетворительные результаты; красный - неудовлетворительные. Даже беглый взгляд учителя на матрицу журнала позволяет сразу же выявить учеников, которым требуется его помощь. Предоставив тем, у кого строка окрашена зеленым, работать самостоятельно, учитель должен разобраться в происхождении желтых и красных ячеек.

Электронный журнал представляет собой интерактивный ресурс. С помощью компьютера, планшета или смартфона можно войти в каждую ячейку, чтобы изучить подробности выполнения задания, так называемый трек. Трек содержит детальную запись всех выполненных ЭУД, где отображены абсолютно все действия ученика: верные и неверные ответы, исправление ошибок (учащемуся предлагаются две дополнительные попытки) или отказ от исправления, а также время выполнения задания, повторное выполнение задания и т. п. Эта фиксация является основой для анализа деятельности ученика. Трек становится доступным учителю сразу после выполнения задания, поэтому он может ознакомиться с результатами ученика непосредственно во время занятий или после их окончания. Изучение трека позволяет учителю понять природу сделанной ошибки: неверно извлеченные исходные данные, ошибки вычисления или списывания, некорректное сравнение или логический вывод и т. п.

Можно пояснить это на следующем примере (рис. 41). Ученик, выполняя задание, верно определил количество проданных шариков, но неверно извлек информацию об их цене. Далее он произвел умножение и получил два неверных ответа, требующих исправления. Однако учитель при изучении цифрового следа ученика может увидеть, что фактически здесь только одна ошибка - извлечения информации, так как вычисление с данными, зафиксированными в тексте, произведено верно.

На втором этапе эксперимента ученики движутся по назначенным траекториям. В процессе работы в дополнение к электронному журналу и трекам заданий учитель получает от экспертной системы информацию о наличии или отсутствии прогресса ученика по каждому из наблюдаемых показателей (рис. 42). Это позволяет использовать методы формирующего оценивания и оперативно вносить коррективы не только в ход тренинга, но и уточнять отношения с другими субъектами, влияющими на успешность ребенка. 
Описанные выше форматы представления данных доступны учителю по всем ученикам его класса. Аналогичные информационные сервисы имеет школьный координатор по всем классам школы, а родители учеников - по своим детям.

\section{5. Фиксация действий учителей и их влияние на результат тренинга}

ЦПНШ позволяет фиксировать действия не только учеников, но и взрослых. Здесь следует отметить, что в рамках эксперимента ставилась задача наблюдения за процессом управления тренингом со стороны преподавателей и координаторов школ. Полученные результаты уже позволяют сделать некоторые предварительные выводы о влиянии поведения взрослых на результативность тренинга.

\section{Регулярность назначения заданий}

Электронный журнал класса предоставляет учителю данные для оперативного управления ходом тренинга. Назначение заданий осуществляется поблочно. На старте автоматически назначается только один (первый) блок заданий, дальнейшее регулирование нагрузки остается за учителем. Рекомендации по назначению заданий были включены в методические материалы для учителей. В частности, было рекомендовано не открывать ученикам доступ сразу ко всем заданиям модуля, а назначать следующий блок, только убедившись, что ученик добросовестно выполнил ранее назначенные задания. Несмотря на это 11 учителей из 50 назначили все задания модуля при первом входе одновременно всем ученикам класса.

Также не рекомендовалось назначать следующие блоки заданий, если результаты ученика по текущему блоку были неудовлетворительными. Анализ действий учителей показал, что практически все они в той или иной степени игнорировали эту рекомендацию и назначали задания, несмотря на плохие результаты ученика, при этом более $30 \%$ учителей делали это регулярно. В итоге это сказалось на индивидуальных и групповых показателях успешности их классов. Ученики 13 из 50 классов показали на первом этапе весьма низкие результаты, и мы вправе предположить, что, по крайней мере частично, неудовлетворительные результаты диагностики явились следствием неправильной организации тренинга.

\section{Сигналы экспертной системы для учителя}

Экспертная система в ходе мониторинга текущих результатов тренинга выявляет типовые «тревожные» ситуации, требующие вмешательства учителя и/или других взрослых. Среди них можно выделить, например, следующие: длительный перерыв в действиях ученика в его личном кабинете, появление в журнале заданий с неудовлетворительными оценками («красные ячейки»), негативная динамика оценок по сравнению с предшествующими периодами и т. д. О возникновении подобных ситуаций экспертная система предупреждает учителя, размещая прямо в электронном журнале соответствующие «флажки», а также текстовые сообщения по конкретным заданиям с возможностью перейти в актуальный трек ученика. Аналогичное оповещение получают и родители этого ребенка. 


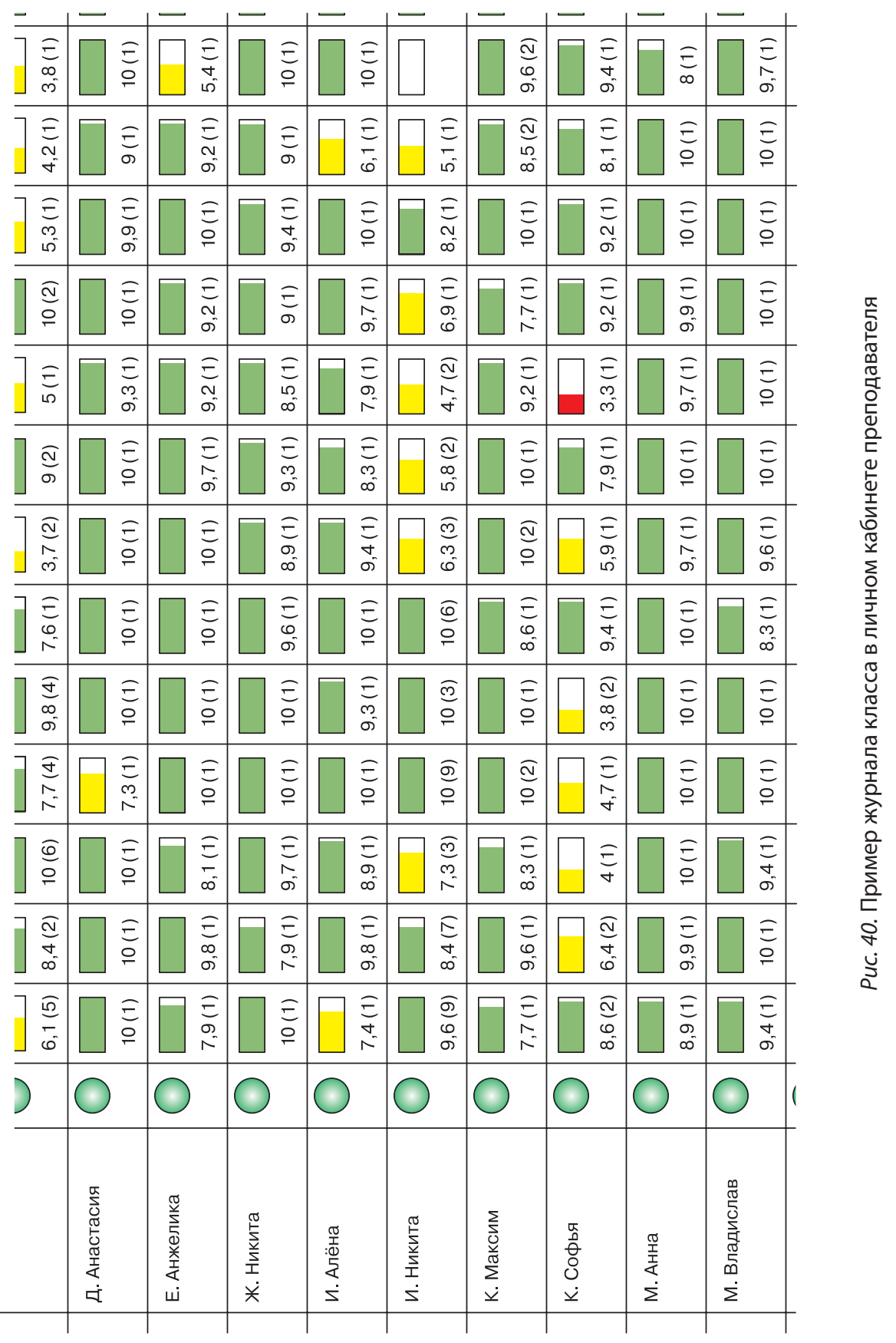




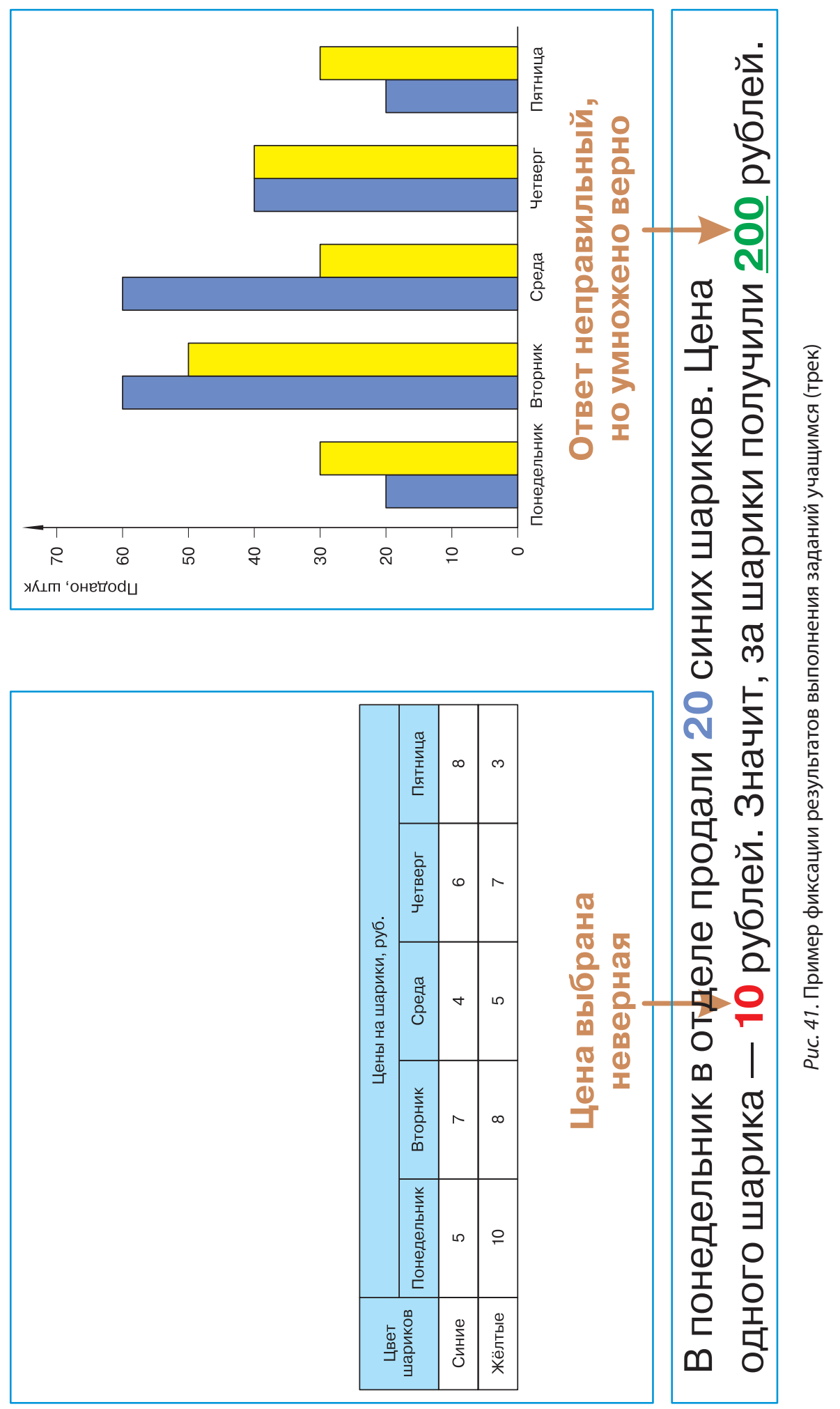




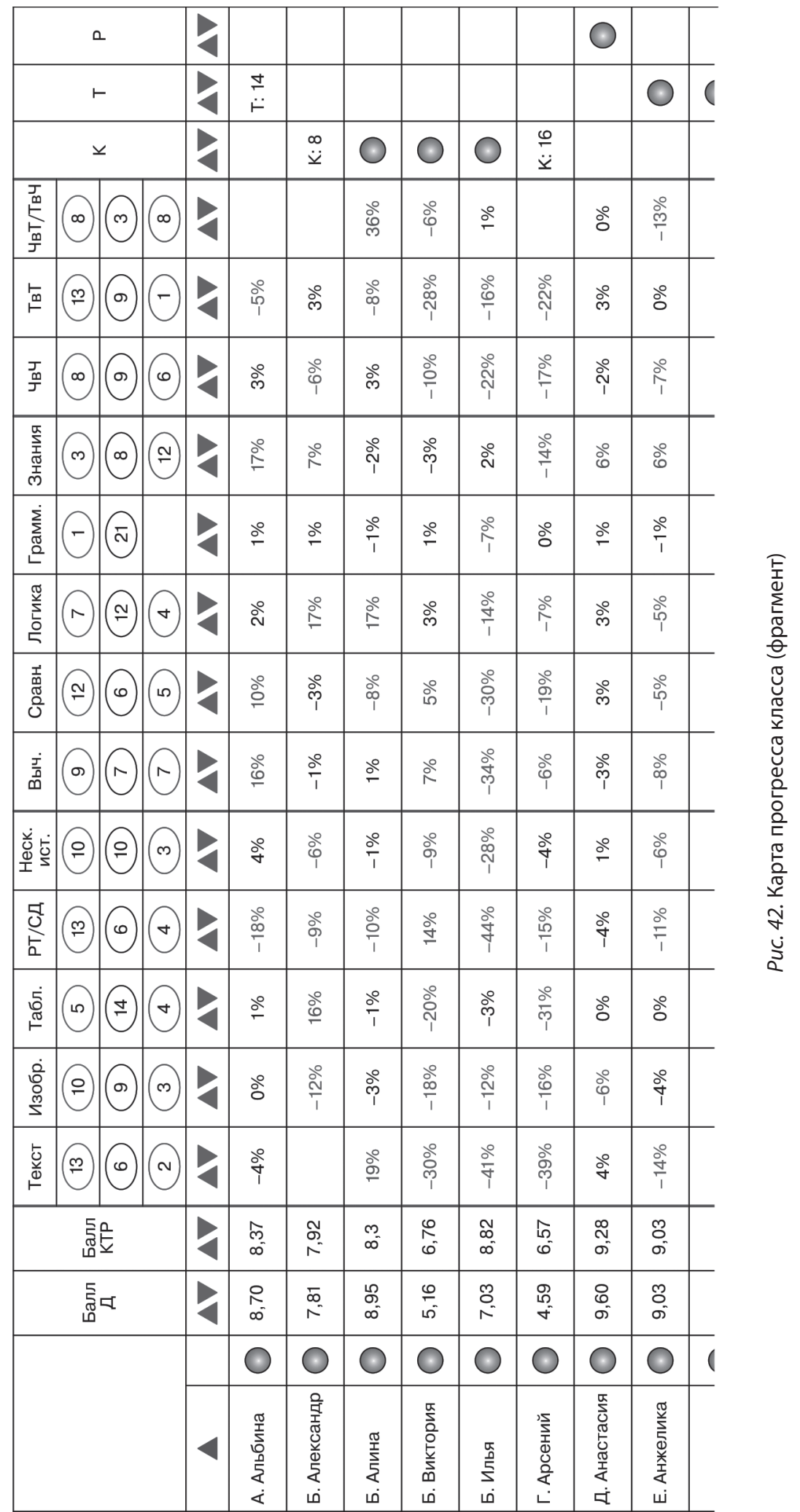


Сигналы экспертной системы получают и учитель, и школьный координатор, который должен обеспечивать контроль за работой учителя, и консультант ЦПНШ, но с разным временным лагом. Сообщения система рассылала по следующему алгоритму:

- через неделю после того, как произошло одно из перечисленных выше событий, сообщение от системы получает учитель (недельный лаг давал ему возможность самостоятельно принять меры в связи с проблемной ситуацией);

- еще через неделю, в случае если учитель не отреагировал на проблемную ситуацию и она осталась неразрешенной, сообщение получает координатор школы;

- еще через неделю, если и координатор не предпринял никаких мер, сообщение получает консультант проекта.

Всего сообщения о проблемных ситуациях получили: учителя 44 классов (из 50 классов - участников эксперимента), то есть почти в 90\% классов были ученики, на проблемы которых учитель не обратил внимания; распределение количества оставшихся неразрешенными проблемных ситуаций представлено в табл. 22.

Таблица 22

Сообщения о проблемных ситуациях, полученные учителями

\begin{tabular}{|l|c|c|c|c|c|}
\hline $\begin{array}{l}\text { Количество } \\
\text { сообщений }\end{array}$ & Не больше 2 & $3-10$ & $11-20$ & $21-40$ & Больше 41 \\
\hline $\begin{array}{l}\text { Количество } \\
\text { классов }\end{array}$ & 6 & 19 & 8 & 9 & 2 \\
\hline
\end{tabular}

После получения сообщений учащиеся восьми классов (в том числе все шесть классов, в которых было не больше двух сообщений) сделали работу над ошибками, и координаторы этих школ сообщений о проблемах уже не получили. В остальных классах эта работа была проделана, но не у всех учащихся ошибки были исправлены. В трех классах учителя никак не отреагировали на сообщения системы, и информация в полном объеме была транслирована координатору школы. Однако координаторы восьми школ (12 классов из 50) не выполнили свои обязанности, количество проблем в этих классах осталось неизменным и было передано консультанту проекта (табл. 23). В то же время в других классах была произведена работа (учителями самостоятельно или под влиянием координаторов), и количество проблемных ситуаций в классах заметно уменьшилось.

Таблица 23

\section{Сообщения о проблемных ситуациях, полученных консультантом ЦПНШ}

\begin{tabular}{|l|c|c|c|c|c|}
\hline $\begin{array}{l}\text { Количество } \\
\text { сообщений }\end{array}$ & Не больше 2 & $3-10$ & $11-20$ & $21-40$ & Больше 41 \\
\hline $\begin{array}{l}\text { Количество } \\
\text { классов }\end{array}$ & 9 & 18 & 3 & 4 & 0 \\
\hline
\end{tabular}

На основании приведенных материалов можно отметить, что цепочка управления, поддерживаемая информацией, предоставляемой экспертной системой ЦПНШ, сработала в 70\% классов. 


\section{Организация учебного процесса: динамика продвижения медианного ученика}

Совместный анализ управленческих и педагогических решений особенно необходим в условиях, когда школа переходит на персонализированную модель обучения. Учителю приходится учитывать индивидуальные особенности детей как при построении их траекторий, так и при планировании учебного процесса в целом. Большая разница в темпах продвижения учеников делает учебный процесс менее предсказуемым. На рис. 43, 44 приведены примеры графиков, представляющих динамику выполнения тренинговых модулей учениками в разных классах.

В ходе анализа этого аспекта управления тренингом были выявлены две основные стратегии назначения заданий, выбранных учителями самостоятельно:

1) стремление к сдерживанию лидеров: все должны двигаться равномерно. Такая стратегия заставляла тех, кто быстро выполнял задания назначенного блока, дожидаться своих одноклассников (иногда довольно долго). Влияние такой стратегии на конечный результат тренинга еще предстоит выяснить, но стоит отметить, что она в определенной степени противоречит идее персонализированного обучения (рис. 43);

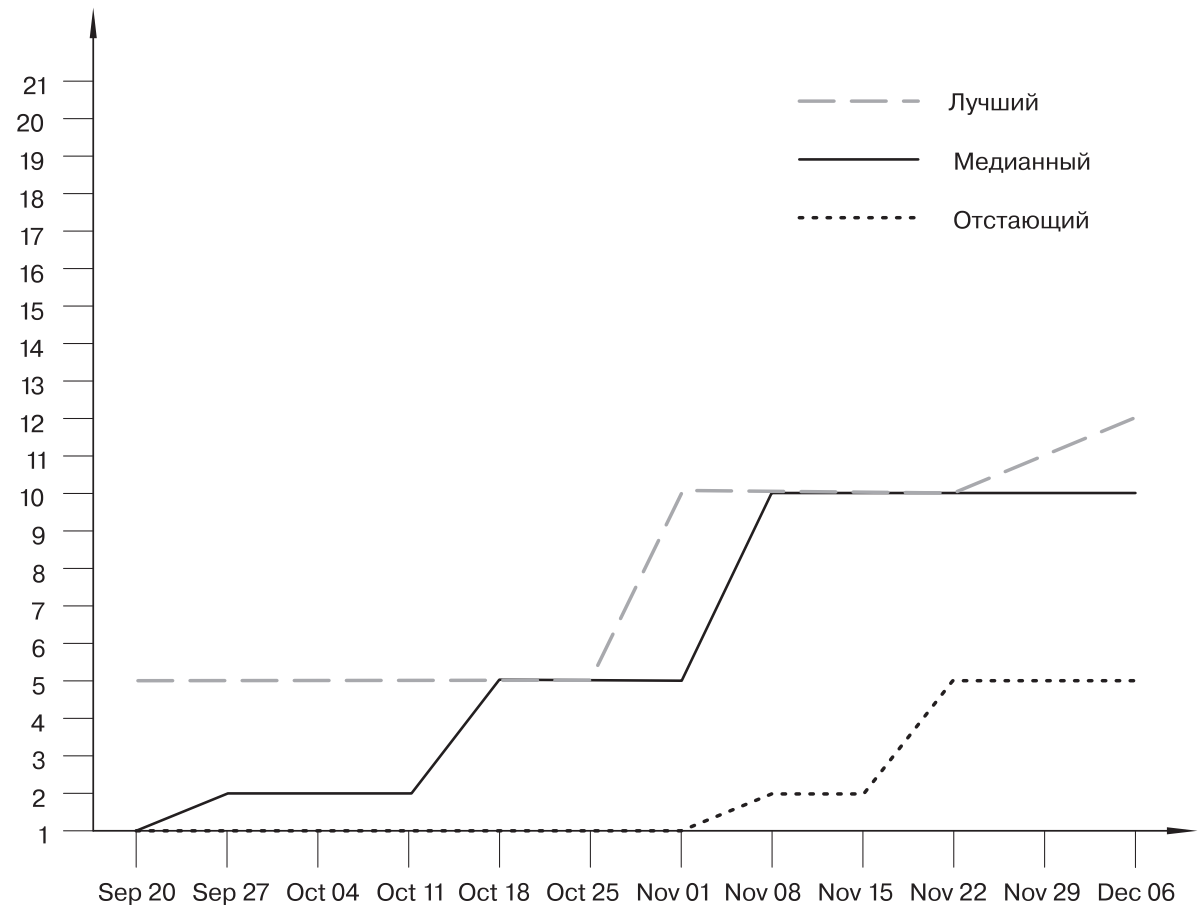

Puc. 43. «Сдерживающий» график назначения заданий

2) предоставление ученикам возможности работать в наиболее комфортном для них режиме. Такая стратегия заставляет учителя более тщательно следить за результатами и динамикой выполнения задания учащимися, но в то же время позволяет ученику сохранять естественный для него темп деятельности и, как следствие, мотивацию к обучению (рис. 44). 


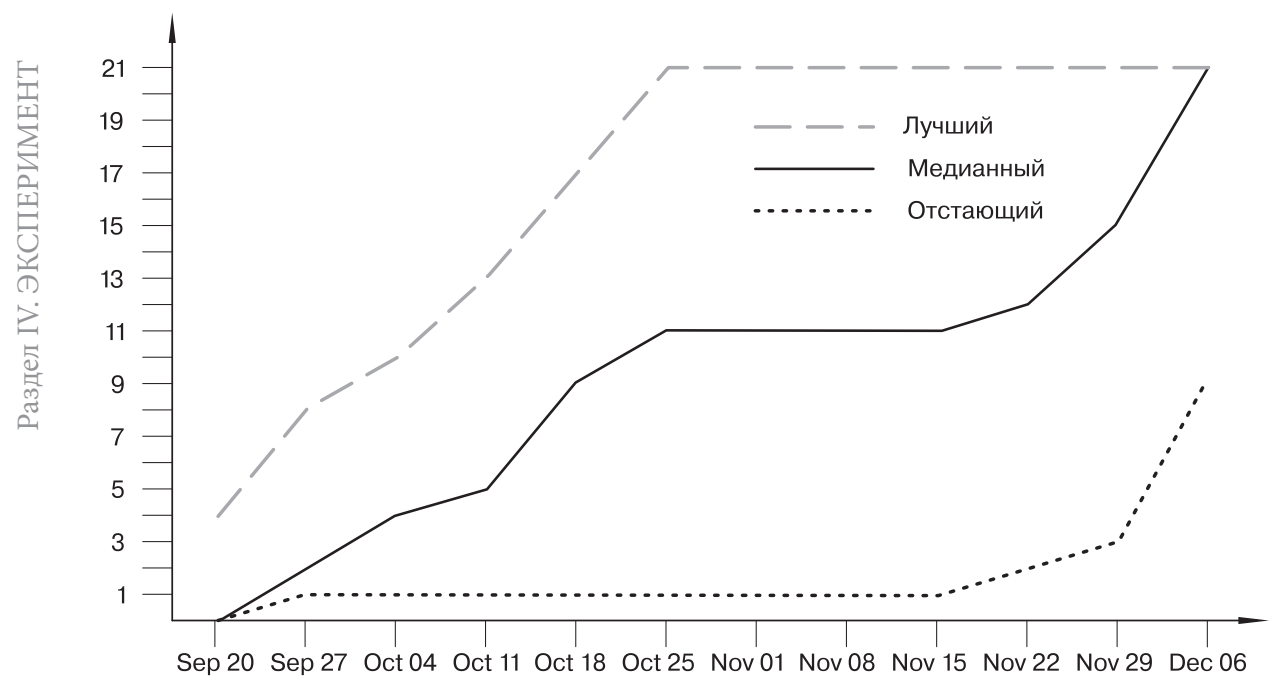

Puc. 44. «Свободный» график назначения заданий

\section{Активность учителей и координаторов школ}

Важным показателем деятельности учителя по организации учебных действий на цифровой платформе является частота его заходов в свой личный кабинет, так как именно там он получает необходимую информацию для понимания возможных проблем конкретных учащихся и выстраивания диалога с ними и их родителями.

Учителя, участвовавшие в эксперименте, проявляли довольно высокую активность в использовании своих личных кабинетов. Первый заход более 80\% преподавателей осуществили в сентябре 2020 г., еще до начала тренинга (октябрь 2020 г.). Заходы осуществлялись для общего знакомства с инструментами ЦПНШ и (как мы можем предположить) чтобы увидеть результаты собственной работы в роли тестового ученика (эта роль позволяет самому учителю выполнить все задания модуля).

На рис. 45, отражающем данные по последним в 2020/2021 учебном году заходам учителей, мы видим, что практически $80 \%$ учителей следили за прохождением тренинга до конца второго этапа, а больше половины продолжали интересоваться ходом работы и в период летних каникул. Это указывает в целом на заинтересованность учителей в результатах учеников. Также можно предположить, что они ценят возможность получить полезные сведения о своих учениках через цифровой след.

Полезной представляется и информация о количестве и частоте заходов учителей в свои личные кабинеты. Общее количество заходов представлено на рис. 46. При этом по частоте заходов учителей в личные кабинеты мы получили следующее распределение: $16 \%$ учителей посещали свои личные кабинеты не реже одного раза в месяц, $24 \%$ - не реже одного раза в две недели, $60 \%$ - не реже одного раза в неделю. Надо отметить, что зависимость между частотой заходов и появлением в личных кабинетах сообщений о существующих проблемах у учащихся выявлена только у половины учителей из тех, которые пользовались личными кабинетами реже одного раза в две недели. Однако регулярность заходов влияла на значительное уменьшение количества проблемных ситуаций после появления предупреждений от экспертной системы. 


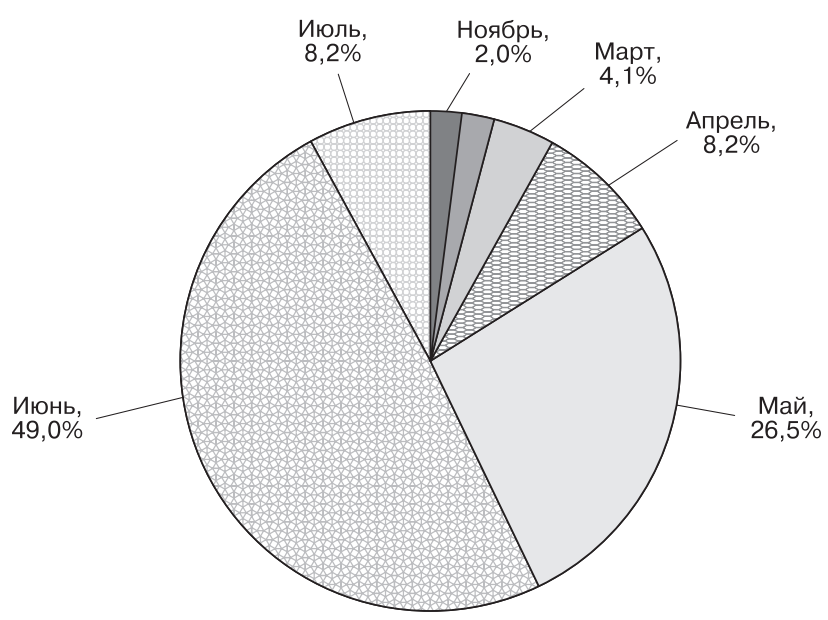

Puc. 45. Последние заходы учителей в свои личные кабинеты в 2020/2021 учебном году

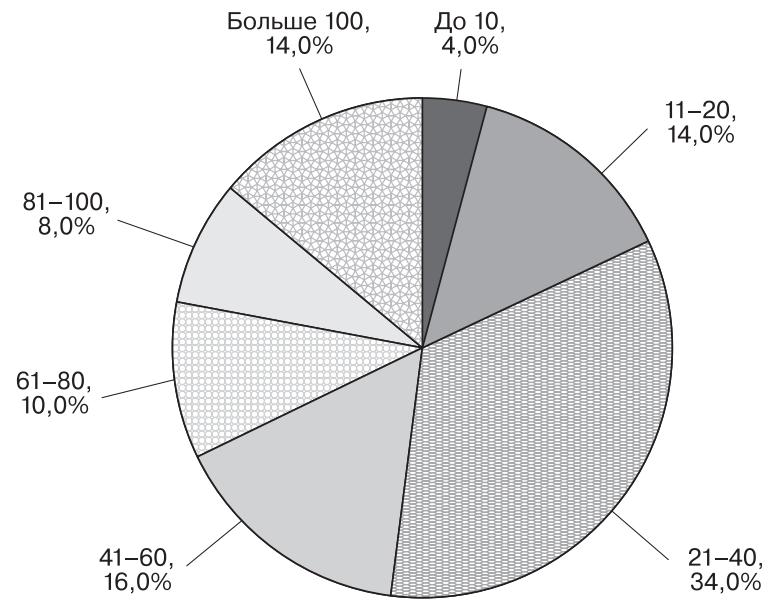

Puc. 46. Общее количество заходов учителей в свои личные кабинеты

Несколько иная ситуация сложилась с активностью координаторов школ. Больше половины координаторов также вошли в свой личный кабинет в сентябре, однако 30\% (а это девять координаторов из 30) ни разу не посетили свои кабинеты. Отсутствие координатора «на рабочем месте» чаще всего влияет на разрыв цепочки «учитель - координатор» при сообщении системой о проблемных ситуациях у учеников, и решение проблемы передается на следующий уровень - консультанта проекта.

Из координаторов, заходивших в личный кабинет в течение учебного года, примерно треть не проявляли никакой активности после января 2021 г. Это означает, что второй этап в семи школах из 21 проходил без прямого участия координатора (или как минимум без анализа ситуации в классах на основе материалов, предоставляемых экспертной системой). Напрашивается вывод, что часть координаторов не осознают значимость предоставляемой информации и важность своего участия в организации учебного процесса. Это реальная управленческая проблема, требующая решения. 
Координаторы, использовавшие данные платформы на протяжении учебного года, заходили в свои кабинеты не реже одного раза в месяц. Такая частота заходов может считаться вполне приемлемой, если по результатам анализа данных координатор обсуждает их с учителем и определяются проблемные места, требующие большего внимания учителя.

\section{Выводы}

Пилотный эксперимент, связанный с моделированием цифровых образовательных отношений, проводился параллельно в 30 образовательных организациях, работающих в различных социальных контекстах в пяти регионах СЗФО. В ходе эксперимента обучающиеся, педагоги и родители школьников использовали различные сервисы цифровой платформы в соответствии со своими субъектными ролями. Школьники выполняли задания в режиме индивидуального компьютерного тренинга, все действия учащихся фиксировались на цифровой платформе. Этот цифровой след использовался взрослыми участниками образовательных отношений для анализа сформированности у обучающихся основ функциональной грамотности и выявления индивидуальных особенностей учебного поведения. Учителя учитывали данные цифрового следа в логике персонализированной модели, то есть при управлении индивидуальными и групповыми траекториями обучающихся. Школьные администраторы также имели доступ к цифровому следу всех обучающихся и к записи управленческих решений учителей, что позволяло корректировать действия педагогов, непосредственно работавших с детьми. Родители школьников в личных кабинетах имели доступ к цифровому следу своих детей и возможность непосредственной коммуникации с учителем и экспертами проекта.

По итогам проектных действий 2020/2021 учебного года можно сделать следующие выводы.

1. Задачи первых двух этапов эксперимента были в целом выполнены, так как школы продемонстрировали свою готовность к инновационной деятельности:

- во всех школах практика информационного тренинга с использованием сервисов ЦПНШ была встроена в учебный процесс на регулярной основе;

- учителя освоили новые цифровые педагогические инструменты, управляли назначением очередных заданий отдельным ученикам или классу в целом; большинство учителей отслеживали цифровой след своих учеников, использовали данные, предоставляемые экспертной системой, для оперативного управления тренингом;

- регулярная работа обучающихся при педагогическом сопровождении со стороны учителей позволила в ходе второго этапа тренинга добиться существенного индивидуального прогресса тем ученикам, у которых на первом этапе были выявлены дефициты значимых умений; у многих «проблемных» детей повысилась мотивация к выполнению учебных действий.

2. Вместе с тем в процессе проведения эксперимента выявились проблемы управленческого характера, негативно повлиявшие на результаты и мотивацию обучающихся: 
- проблемы педагогического сопровождения: около $25 \%$ учителей не проявили умения управлять индивидуальными траекториями, правильно дозировать учебную нагрузку, добиваться от учеников работы над ошибками и т. д.;

- неготовность к использованию сведений, предоставляемых экспертной системой: многие учителя не реагировали на «тревожные сигналы» и не следовали рекомендациям экспертов проекта;

- проблемы управления учебным процессом: более $60 \%$ школьных координаторов оказались неготовыми к тем новым возможностям, которые были им предоставлены в аналитике цифрового следа; они не были активны ни в организации учебных занятий, ни в мониторинге результатов, ни в корректировке действий учителей;

- проблемы коммуникации с семьями учеников: не все родители получили от школ информацию о возможности наблюдения за работой своих детей.

3. Можно заключить, что перенос инновационной ЦУП в регулярный учебный процесс начальной школы не встречает серьезных организационных препятствий, несмотря на ограниченность компьютерного ресурса во многих школах. Вместе с тем эксперимент показывает низкую готовность многих педагогов к использованию принципиально новых информационных возможностей цифровых технологий, к изменениям в межсубъектных отношениях. Перечисленные пробелы будут учтены при организации третьего этапа эксперимента, что позволит, как мы надеемся, добиться более высоких показателей индивидуального прогресса и эффективной работы учебных коллективов.

4. Следует обратить особое внимание всех участников образовательного процесса на потенциал цифрового следа как информационной основы для принятия и согласования управленческих решений. Изменение их поведения в логике гибкого саморегулирования (самообучения) в зависимости от сигналов обратной связи послужит важным фактором развития отношений между субъектами образовательного процесса.

\section{Литература}

1. Воровщиков С. Г. Достоинства и недостатки перечня универсальных учебных действий Федерального государственного образовательного стандарта общего образования / С. Г. Воровщиков // Интернет-журнал «Эйдос». 2012. № 5 [Электронный ресурc]. URL: http://www.eidos.ru/ journal/2012/0829-5.htm (дата 0бращения: 12.07.2021).

2. Выготский Л. С. Проблема обучения и умственного развития в школьном возрасте // Л. С. Выготский. Избранные психологические исследования. М., 1956.

3. Кондратьева И. Н., Рубашкин Д. Д. Начальная школа в условиях цифровизации: активные учебные практики как педагогический инструмент достижения метапредметных результатов. Перспективы и приоритеты педагогического образования в эпоху трансформаций, выбора и вызовов: VI Виртуальный Международный форум по педагогическому образованию : сборник научных трудов. Ч. ІІІ. Казань : Издательство Казанского университета, 2020. 316 с.

4. Любимов Л. Л. Концепция модернизации общего образования. Без лозунгов, призывов и наставлений, но с ответами на вопросы: Что надо делать? Почему это надо делать? Как это можно сделать? / Л. Л. Любимов ; Национальный исследовательский университет «Высшая школа экономики», Институт образования. М. : НИУ ВШЭ, 2020.80 с. (Современная аналитика образования. № 2(32)). 


\section{ШКОЛЫ — УЧАСТНИЦЫ ЭКСПЕРИМЕНТА}

\section{Псковская область}

Координатор - ИПКРО Псковской области

МБОУ «Средняя общеобразовательная школа № 1» (г. Великие Луки)

МБОУ «Дедовичская средняя школа № 2» (пос. Дедовичи)

МБОУ «Куньинская средняя общеобразовательная школа» (пос. Кунья)

МБОУ «Палкинская средняя школа» (дер. Палкино)

МБОУ «Печорская гимназия» (г. Печоры)

Школыг. Пскова

МБОУ «Лицей „Развитие“»

МБОУ «Псковская инженерно-лингвистическая гимназия»

МБОУ «Средняя общеобразовательная школа № 2»

МБОУ «Средняя общеобразовательная школа № 18 имени Героя Советского Союза

генерала армии В. Ф. Маргелова»

МБОУ «Средняя общеобразовательная школа № 24 имени Л. И. Малякова»

МБОУ «Средняя общеобразовательная школа № 47»

\section{Санкт-Петербург}

Василеостровский район

Координатор — ИМЦ Василеостровского района

ГБОУ «Средняя общеобразовательная школа № 5 Василеостровского района Санкт-Петербурга»

ГБОУ «Средняя общеобразовательная школа № 6 Василеостровского района Санкт-Петербурга»

ГБОУ «Средняя общеобразовательная школа № 17 Василеостровского района Санкт-Петербурга»

ГБОУ «Средняя общеобразовательная школа № 19 Василеостровского района Санкт-Петербурга»

ГБОУ «Средняя общеобразовательная школа № 21 Василеостровского района Санкт-Петербурга имени Э. П. Шаффе»

ГБОУ «Гимназия № 32 Василеостровского района Санкт-Петербурга»

Красносельский район

Координатор — ИМЦ Красносельского района

ГБоУ «Школа № 219 Красносельского района Санкт-Петербурга»

ГБОУ «Школа № 242 суглубленным изучением физики и математики Красносельского района

Санкт-Петербурга»

ГБОУ «Средняя общеобразовательная школа № 276 Красносельского района Санкт-Петербурга»

ГБОУ «Школа № 375 с углубленным изучением английского языка Красносельского района Санкт-Петербурга»

ГБоУ «Средняя общеобразовательная школа № 385 Красносельского района Санкт-Петербурга»

ГБОУ «Школа № 509 Красносельского района Санкт-Петербурга»

ГБОУ «Средняя общеобразовательная школа № 549 с углубленным изучением английского языка Красносельского района Санкт-Петербурга»

Другие районы

ГБОУ «Средняя общеобразовательная школа № 77 с углубленным изучением химии Петроградского района Санкт-Петербурга»

ГБОУ «Средняя общеобразовательная школа № 182 Красногвардейского района Санкт-Петербурга»

ГБоУ «Средняя общеобразовательная школа № 621 Колпинского района Санкт-Петербурга»

\section{Ленинградская область}

МБОУ «Гатчинская начальная общеобразовательная школа № 5» (г. Гатчина)

\section{Калининградская область}

МАОУ города Калининграда средняя общеобразовательная школа № 56 (г. Калининград)

\section{Республика Карелия}

МБОУ Петрозаводского городского округа «Центр образования и творчества „Петровский Дворец“» (г. Петрозаводск) 


\section{Раздел V}

\section{В ЧЕМ ВОПРОС?}





\section{ГЛАВА 10}

\section{Образовательные отношения и ценности: зачем нам «цифра»?}

\section{1. Теоретические основы анализа образовательных отношений}

Образовательные отношения неизбежно связаны с оценкой значимости образования. В связи с этим анализ образовательных отношений возможен с позиций аксиологического подхода. Проблема ценности образования рассматривается аксиологией образования, которая является одной из областей педагогической аксиологии.

В работах, опубликованных в XXI в. [Гусинский; Запесоцкий; Касаткин; Кирьянова], отмечается, что образование, с одной стороны, является механизмом трансформации ценностей, а с другой стороны, выступает как объект ценностного отношения. Такое отношение проявляется в характеристиках, свойственных формам общественного сознания: значимость, нормативность, полезность, необходимость, целесообразность. Представления о значимости образования и других перечисленных характеристиках с развитием общества меняются. Эволюция ценностей общества происходит под влиянием множества факторов: объекты оценки могут оставаться прежними, но критерии оценки меняются.

В научной литературе предлагаются различные классификации ценностей. Различают терминальные и инструментальные, социальные и личностные ценности. В социологии используется понятие «ценностные ориентации личности» - разделяемые личностью социальные ценности, выступающие в качестве целей жизни и основных средств достижения этих целей.

При анализе изменений отношения к школьному образованию как ценности вполне возможно опираться на классификацию В. А. Ядова, который выделяет ценности-нормы, ценности-идеалы, ценности-цели и ценности-средства, а также на его выводы о трансформационных процессах, протекающих в обществе [Ядов]. Исходя из данной позиции, школьное образование может рассматриваться как обязательная норма, как самостоятельная цель, как средство реализации других целей. При этом критерием оценки реальной образовательной практики становится ценность-идеал: соотношение сущего и должного, соотношение представлений о существующей практике и представлений о том, какой она должна быть. Ценность образования определяется его значимостью для развития личности. Но для развития личности имеют существенное значение разные виды деятельности, и образовательная деятельность является лишь одной из них.

Применительно к общему образованию терминальные ценности можно описать ключевыми словами, раскрывающими смысл образования: 
воспитание, «школа дисциплины», «школа свободомыслия», сохранение традиций, «культура полезности» или «культура достоинства» (термины А. Г. Асмолова). Инструментальные ценности общего образования в этом случае могут быть определены в терминах, раскрывающих его значимость для изменения социальной структуры общества: «социальный лифт», «социальный фильтр», «социальное равенство». Данный перечень ключевых слов может быть продолжен.

Указанные ключевые слова отражают разные представления о терминальной и инструментальной ценности образования. В связи с этим перед школой всегда стоит проблема выбора ценностных ориентиров. Терминальные личностные ценности можно описать в понятиях «идеалы», «жизненные цели», «самоопределение», «образованный человек». Инструментальные ценности могут найти отражение в понятиях компетентности, функциональной грамотности, познавательной самостоятельности, знания, умения. Участники образовательных отношений могут ориентироваться на разные личностные ценности, которые могут по-разному соотноситься с социальными ценностями.

Ценностные ориентации участников образовательных отношений, с одной стороны, влияют на характер этих отношений, а с другой стороны, складываются под их влиянием. В свою очередь, образовательные отношения выступают фактором, определяющим потенциал системы образования.

Каждая система образования обладает определенным потенциалом, который может быть достаточным или недостаточным для реализации социальных функций этой системы, меняющихся в процессе развития общества. Реальные возможности конкретной системы образования отличаются от ее теоретических возможностей. В связи с этим развитие системы образования можно рассматривать как процесс приближения реальных возможностей системы к теоретическим возможностям. При анализе такого процесса можно опираться на философские исследования по проблемам соотношения возможности и действительности, целеполагания и целереализации.

Реальные возможности системы образования и ее реализуемые возможности также отличаются. Фактором превращения реальных возможностей системы в действительность является управление системой. При анализе феномена управления образовательными отношениями аксиологический подход необходимо сочетать с имеющимся опытом исследований по общим проблемам управления социальными системами и специфическим проблемам управления развитием образовательных систем, а также исследований, раскрывающих смысл и цели образования на разных этапах развития общества [Ван Гиг; Днепров; Лебедев 2011, 2012, 2016; Российская школа...; Смыслы и цели...; Хэтти].

Анализ образовательных отношений предполагает раскрытие сущности понятия «образование».

В «Педагогической энциклопедии», изданной в 1966 г., образование определяется как процесс и результат усвоения систематизированных знаний, умений и навыков. В «Российской педагогической энциклопедии» (1999) под образованием понимается процесс педагогически организованной социализации, осуществляемой в интересах личности и общества, объединяющий обучение и воспитание, обеспечивающий культурную преемственность поколений и готовность человека к выполнению социальных и профессиональных ролей. 
Ориентация не только на социальную, но и на личностную значимость образования сохраняется и усиливается в тексте закона «Об образовании в Российской Федерации», принятого в 2012 г. (ст. 2, п. 1): «Образование единый целенаправленный процесс воспитания и обучения, являющийся общественно значимым благом и осуществляемый в интересах человека, семьи, общества и государства, а также совокупность приобретаемых знаний, умений, навыков, ценностных установок, опыта деятельности и компетенции определенных объема и сложности в целях интеллектуального, духовно-нравственного, творческого, физического и (или) профессионального развития человека, удовлетворения его образовательных потребностей и интересов».

Анализ изменений в определении сущности образования дает основания для следующих выводов:

- происходит расширение круга значимых результатов образовательной деятельности (знания, умения, навыки, ценностные установки, опыт, компетенции);

- фиксируется повышение значимости образования для развития личности (интеллектуальное, духовно-нравственное, творческое, физическое развитие), готовности обучающихся к выполнению социальных ролей;

- отмечается связь между достижением желаемых образовательных результатов и личностной ценностью образования (соответствие интересам, потребностям обучающихся); иначе говоря, отмечается возрастание роли субъективного фактора в достижении ожидаемых образовательных результатов.

Можно сказать, что результативность образования все более определяется его релевантностью, а социальная значимость образования зависит от его личностной значимости.

Показателем личностной значимости образовательных результатов можно считать способность к решению проблем, возникающих в различных сферах и видах деятельности. С этой точки зрения образование можно определить как специально организованный процесс развития у обучающихся способности к самостоятельному решению социально и личностно значимых проблем в различных срерах и видах деятельности на основе использования социального опыта, элементом которого является собственный опыт обучающихся.

Достигнутый уровень образованности определяет приобретенные возможности личности в решении проблем самопознания и самоопределения, социализации, продолжения образования.

Таким образом, ключевыми понятиями, определяющими теоретические основы анализа образовательных отношений, являются: образование, ценность, потенциал системы образования, управление развитием образовательных систем.

\section{2. Образовательные отношения как объект анализа}

В законе «Об образовании в Российской Федерации» (ст. 2, п. 31) к участникам образовательных отношений отнесены обучающиеся, родители (законные представители несовершеннолетних обучающихся), педагогические 
работники и их представители, организации, осуществляющие образовательную деятельность.

Участники образовательных отношений рассматриваются как субъекты образовательной деятельности. Закон предоставляет обучающимся, родителям несовершеннолетних обучающихся, педагогическим работникам права, связанные с организацией образовательного процесса и управлением образовательными организациями, а также возлагает на них определенные обязанности и ответственность. Закон «Об образовании в Российской Федерации» создает правовую основу для формирования субъект-субъектных отношений участников образовательного процесса.

Применительно к общеобразовательной школе под образовательными отношениями понимаются: отношение учащихся, их родителей, педагогических работников, школьных администраторов к образованию и к образовательной программе, которая реализуется в образовательном процессе; отношения между учащимися, родителями, педагогическими работниками, школьными администраторами как участниками образовательного процесса.

С позиций системного подхода совокупность образовательных отношений можно рассматривать как систему, которая является элементом локальной образовательной системы (рис. 47).

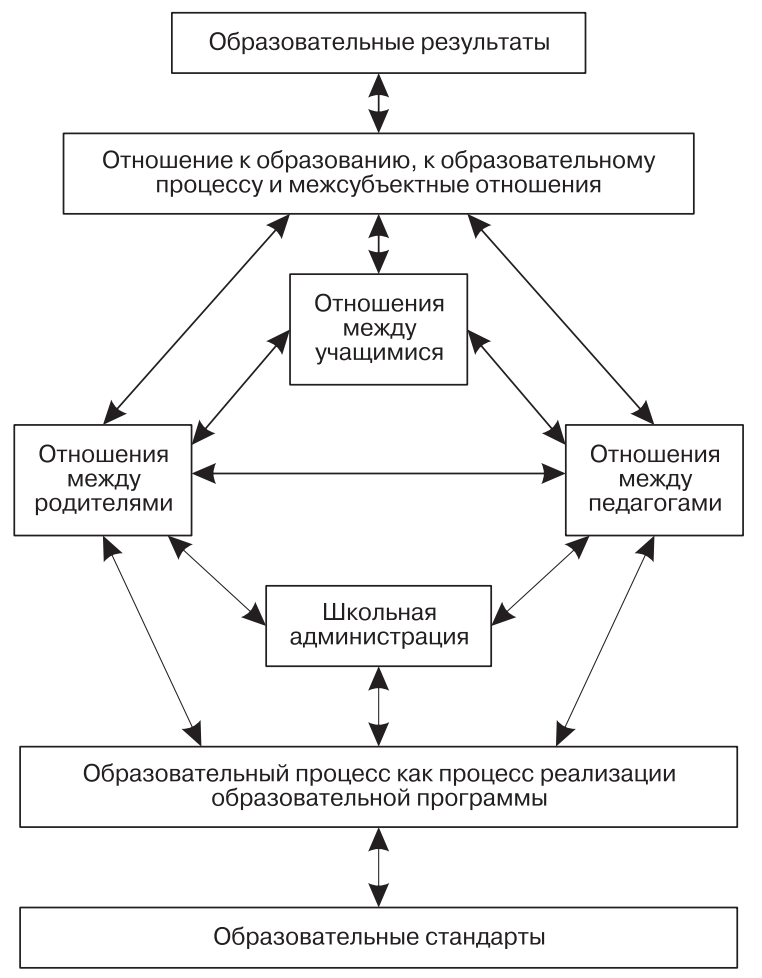

Puc. 47. Локальная образовательная система

Основной характеристикой образовательного процесса является его качество, которое можно рассматривать как совокупность качеств, которыми обладает этот процесс. Речь идет о таких качествах, как динамичность (гибкость, вариативность), открытость (использование разнообразных источников образовательной информации), интегративность (взаимосвязь 
предметов, взаимосвязь разных видов образовательной деятельности), преемственность (взаимосвязь этапов образовательного процесса), интерактивность (взаимодействие участников образовательного процесса), адаптивность (возможность индивидуализации образовательного процесса).

Основным качеством образовательного процесса является его целенаправленность, которая определяет его результативность. Данное качество образовательного процесса определяется в значительной мере отношениями его участников

Локальные системы общего образования, существующие в общеобразовательных школах, имеют общие и индивидуальные черты. Их общие черты определяются едиными правовыми рамками, действующими образовательными стандартами и организационной формой образовательного процесса (предметно-классно-урочная система). Индивидуальные черты локальных систем определяются образовательной программой, которая реализуется в конкретной школе, и отношениями участников образовательного процесса.

Связи между элементами локальной образовательной системы выражаются в следующем:

- образовательные результаты всегда относятся к сфере деятельности учащихся и в конечном счете определяются отношением учащихся к своей образовательной деятельности, которое проявляется в их действиях;

- факторами, влияющими на образовательные результаты, являются позиции взрослых участников образовательного процесса - родителей и педагогов, их представления о значимости образования, которое дает школа, и о своей роли в осуществлении образовательного процесса;

- отношение участников образовательного процесса к данному процессу, который проходит в конкретной локальной образовательной системе, и их отношение к образованию как социальной и личностной ценности могут различаться: представления о ценности образования могут выступать как критерии оценки конкретной образовательной ситуации;

- факторами, определяющими отношение учащихся к образованию и образовательному процессу, являются их отношения с педагогами и родителями, а также отношения между самими учащимися;

- на отношение родителей к образованию и к образовательному процессу влияют многие факторы (в том числе их собственный образовательный опыт); к факторам, на которые может влиять школа, относятся: отношения родителей с педагогами; отношение родителей к собственным детям как учащимся (имеющим определенные права и обязанности); отношения с администрацией школы (отношение к принятым в школе нормам), а также отношения между самими родителями;

- на позицию педагогов также влияют многие факторы (включая полученное профессиональное образование, опыт педагогической деятельности, достигнутый уровень квалификации), в том числе их отношения между собой и с администрацией школы; в свою очередь, позиция педагогов определяет характер их отношений с учащимися и родителями;

- позиция школьной администрации определяется внешними требованиями (образовательными стандартами, указаниями управленческих структур), ожиданиями участников образовательного процесса (педагогов, родителей, учащихся), собственной оценкой потенциала образовательной системы; позиция школьной администрации влияет на создание условий образовательной деятельности, проектирование образователь- 
ной программы и организацию образовательного процесса, включая способы взаимодействия его участников;

- сущностью образовательного процесса является реализация образовательной программы; он осуществляется в определенной организационной форме, которая задает и определенные рамки отношений участников образовательного процесса; вместе с тем эти отношения могут существенно влиять на содержание образовательного процесса;

- государственные образовательные стандарты определяют требования к результатам освоения основных образовательных программ, к содержанию этих программ, к условиям их реализации; они в значительной мере, но все же далеко не полностью определяют содержание образовательного процесса, многие компоненты которого определяются на уровне локальной образовательной системы.

Изменения в представлениях о структуре и содержании образовательного процесса дают возможность выявить вполне определенную тенденцию в подходе к пониманию образовательного процесса как процесса взаимодействия его участников [Новиков]. Речь идет о взаимодействии не только педагогов с учащимися или учащимися и другими участниками образовательного процесса, но и о взаимодействии внутри групп этих участников (между учителями, между учениками, между родителями).

Выше было отмечено многообразие видов образовательных отношений, которые могут стать предметом анализа и управления. При анализе образовательных отношений в локальных системах образования следует иметь в виду динамический характер системы образования, в которой постоянно происходят те или иные изменения. Масштабы и характер таких изменений могут существенно различаться. Они могут происходить на технологическом уровне (появление новых методических приемов, средств обучения, образовательных технологий), на организационно-педагогическом уровне (появление новых видов образовательных учреждений, организационных структур внутри образовательного учреждения), на уровне модернизации содержания образования, его целей.

Указанные изменения влияют на характер образовательных отношений, но и образовательные отношения влияют на такого рода изменения. В одном случае может наблюдаться тенденция воспроизведения сложившихся отношений, препятствующая каким-то существенным переменам в системе образования. В другом случае может иметь место стремление к преодолению существующего характера отношений, стимулирующее изменения в системе образования.

\section{3. Факторы изменений образовательных отношений}

Эти факторы можно разделить на две группы - внесистемные и внутрисистемные процессы. В первом случае речь идет о процессах, происходящих в обществе и влияющих на поведение участников образовательного процесса, во втором случае имеются в виду изменения в самой системе образования.

Среди внесистемных факторов следует выделить процесс, который характеризуют как смену поколений. Следствием этого процесса являются качественные изменения в составе участников образовательного процесса, 
влияющие на характер их отношений, поскольку учащиеся, их родители и педагоги могут принадлежать к разным поколениям.

Под поколением обычно понимают совокупность людей, которые родились в определенный период времени и в силу этого прошли процесс социализации, ориентированный на общие ценности и соответствующие им принципы воспитания. Существуют разные теории поколений, которые акцентируют внимание на различном характере взаимодействия поколений. Г. Маркузе развивал теорию «конфликта поколений», обусловленного стремлением младшего поколения занять место старшего. Дж. Г. Мид исходил из того, что культура общества определяется тем, какой характер отношений между поколениями является доминирующим - молодое поколение учится у старшего, происходит взаимообучение среди равных по возрасту, зрелое поколение «учится» у молодого поколения. А. Тойнби пришел к выводу, что «вызов времени», связанный с процессами, происходящими в разных сферах жизни общества, неизбежно ведет к «ответу» нового поколения, создавая ситуацию «жизненного прорыва», который может произойти в форме революции, общественных волнений, развития радикальных движений.

Стоит заметить, что при обсуждении современных проблем и перспектив развития образования отмечается, что образовательные учреждения представляют собой центры концентрации молодежной энергии, способной превратиться в мощную социальную деятельность, направленность которой может быть различной. Сказанное относится прежде всего к университетам, но и старшая школа дает примеры проявления социальной активности, далеко не всегда управляемой.

Получила известность следующая классификация поколений, последовательно сменявших друг друга: «поколение победителей» (1900-1923 г. р.); «молчаливое поколение» (1923-1943 г. р.); «поколение бэби-бумеров», которое считается последним советским поколением (1943-1963г. р.); «поколение X», которое называют «поколением перестройки» (1964-1984 г. р.); «поколение Y» (1985-2000 г. р.); «поколение Z» (родившиеся в XXI в.), которое определяют как «поколение рожденных цифровой революцией». Данная классификация часто становилась объектом научной критики, но сама попытка выявить значимые черты поколений стимулирует анализ особенностей современного поколения.

Дж. М. Твенге в своем исследовании современного поколения американских подростков выделила следующие его особенности: медленное взросление; время, проводимое онлайн; заочное обучение; неуверенность; потеря интереса к религии; изолированность и приземленность; финансовая незащищенность; новый взгляд на секс, брак, детей; терпимость, всеобщее равенство и свобода слова; независимость в политических взглядах [Твенге, с. 18].

В имеющихся исследованиях выделяют ряд факторов, влияющих на процесс социализации поколения Z в российских условиях. B «нулевые годы» XXI в. наблюдался экономический подъем, в условиях которого мир казался рациональным и предсказуемым. В следующем десятилетии ситуация изменилась. В работе М. Д. Матюшкиной «Выпускник петербургской школы: от поколения Y к поколению Z» [Матюшкина] эти изменения характеризуются следующим образом: «Вместе с ожидаемым информационным взрывом в 10-е годы пришел неожиданный поворот к непредсказуемости, сильно повлиявший на все стороны жизни. Если в предсказуемом мире лучшей жизненной стратегией является стратегия вклада в будущее (образование, 
целеустремленность, накопление, забота о детях, об экологии и т. д.), то в непредсказуемом мире такая стратегия обесценивается, более адекватной ему становится стратегия ориентации на сиюминутный успех и случай».

Опираясь на материалы опроса выпускников петербургских школ и материалы других социологических исследований, М. Д. Матюшкина отмечает, что и в неспокойной обстановке второго десятилетия XXI в. сохраняется стремление родителей обеспечить благополучие своих детей, защитить их от возможных рисков. В итоге период детства начинает увеличиваться. Средства мобильной связи расширяют возможность контролировать поведение детей, опекать их. Такое поведение родителей не является специфичным для России.

Отмечаются изменения, которые происходят в образе жизни современного молодого поколения (интернет-активность, рост интереса к занятиям спортом и различными видами самодеятельного творчества, распространение «моды» на здоровое питание, развитие ориентации на потребительские ценности). Отмечаются признаки появления игромании, которая ведет к замене реального мира виртуальным.

Как замечает М. Д. Матюшкина, средствами рекламы создается «образ уверенного в себе, красивого, здорового, сильного человека, любящего себя и заботящегося о себе» [Там же]. Этот образ становится ориентиром при формировании у молодых людей представлений о своем будущем.

К фактору смены поколений необходимо добавить еще один фактор, отражающий особенности современного этапа развития российского общества. Его можно определить как кризис ценностных основ российского общества. Кризис выражается в утрате ценностей советского общества при одновременном существовании ностальгии по этим ценностям. Вместе с тем вряд ли существует желание вернуться к жизни в коммунальных квартирах, очередям за предметами первой необходимости, массовым политическим репрессиям. Скорее такая ностальгия связана с отсутствием ценностей, объединяющих российское общество и задающих направление его развития. «Взгляд назад», обращение к прошлым победам и достижениям играет существенную роль в решении проблем социокультурной идентификации, но не заменяет «взгляда вперед», играющего решающую роль в определении места современного поколения в развитии общества.

Указанные внесистемные процессы обуславливают возможные риски в развитии системы школьного образования. В условиях доминирования «коротких планов», отсутствия ясных перспектив развития российского общества возникает риск ориентации преимущественно на инструментальные ценности образования. При такой ориентации школа может рассматриваться лишь как средство подготовки к профессиональному образованию.

Продление детства, ориентация на комфортные условия образовательной деятельности порождают риск чрезмерного увлечения игровыми технологиями и превращения образовательного процесса из «полосы препятствий» (когда надо приобрести опыт их преодоления) в «пешеходную улицу» (дающую возможность получить удовольствие от прогулки).

Изменения в структуре образа жизни создают риск того, что экстенсивное развитие образования, ориентированное на постоянное увеличение затрат временных ресурсов учащихся, будет все меньше влиять на качество образовательных результатов (а цена их достижения будет возрастать).

К внутрисистемным процессам, влияющим на образовательные отношения, следует отнести ряд явлений в сфере образования, которые можно считать не- 
обратимыми. Первое из них - расширение образовательного пространства учащихся, что связано с развитием средств массовой информации и появлением новых внешкольных источников образовательной информации.

Снижение значимости школьного образования в условиях появления новых источников информации было зафиксировано еще в конце 1960-х гг. В докторской диссертации Ю. В. Вайткявичюса [Вайткявичюс] были приведены данные сравнительного анализа ответов учащихся на одни и те же вопросы в области естественных наук в 1958 г. и в 1968 г. Выяснилось, что ответы учащихся в 1968 г. были более полными, но при этом показатели динамики их успеваемости в 5-8-м классах были хуже по сравнению с 1958 г. Учащиеся стали знать больше, а учиться стали хуже. «Пополнение» знаний объясняется использованием внешкольных источников информации. Роль Интернета в дальнейшем развитии данного процесса не требует комментариев.

Второй процесс - демонополизация школьного образования. Школа перестает выступать в роли единственного (а в ряде случаев и основного) центра общего образования. Уже в советское время возникла масштабная практика репетиторства, которая не столько дополняла школьное образование, сколько компенсировала его недостатки (отчасти связанные с качеством обучения, отчасти - с ограниченными возможностями его индивидуализации). Масштабы репетиторства возрастают, в том числе в связи с тем, что репетиторские услуги начинают использоваться и в начальной школе.

В советское время также получили распространение подготовительные курсы при высших учебных заведениях, которые стали более разнообразными по формам организации учебного процесса. По данным исследования «Выпускник петербургской школы» (2018 г.), дополнительно занимались с целью подготовки к поступлению в вуз: с репетитором - 61,4\% выпускников средней школы, на курсах при вузе - 26,1\%, в других организациях - 17,9\%.

К этому надо добавить, что в общественном мнении складывается представление о дополнительном образовании как необходимом компоненте общего образования. Центры дополнительного образования становятся все более разнообразными (кванториумы, Академия талантов, «Кидбург», «Сириус» и др.), а масштабы его возрастают. Уже к концу «нулевых годов» XXI в. охват детей программами дополнительного образования составил 53,5\% детей в возрасте 5-18 лет (в 2000 г. этот показатель составлял 34\%) [Образование в Российской Федерации..., с. 273]. Развитие представлений о содержании общего образования становится фактором, влияющим на критерии оценки значимости школьного образования.

Альтернативой традиционному школьному образованию могут стать и различные варианты дистанционного обучения, предполагающие возможность самостоятельного освоения школьной программы.

Вполне вероятно, что процесс демонополизации школьного образования приведет к появлению его новых организационных форм (сочетание «очного» обучения с «заочным», отказ от класса как структурной единицы школы и от урока как формы учебного процесса).

Третий процесс - увеличение продолжительности всеобщего обязательного образования, вызвавшее поиск путей его индивидуализации, без которой невозможно обеспечить качество образования, соответствующее современным общественным вызовам.

К этому надо добавить, что происходит увеличение продолжительности всеобщего образования в связи с повышением доступности дошкольного 
образования. В итоге возникают новые возможности для обеспечения преемственности дошкольного и начального общего образования: если большинство будущих первоклассников получают дошкольное образование в условиях детского сада, то появляется возможность прогнозировать особенности обучения нового поколения младших школьников и заранее готовиться к решению проблем индивидуализации образовательного процесса. Неизбежность ориентации на поиск новых возможностей для индивидуализации образовательного процесса связана также с расширением масштабов инклюзивного образования.

На характер образовательных отношений влияют еще два внутрисистемных процесса:

- уменьшается разница между уровнем образования родителей и педагогов, все родители обладают собственным опытом школьного образования и собственными представлениями о должном школьном образовании;

- в постсоветский период и у родителей, и у педагогов сложилось представление о праве на выбор как значимой личностной ценности и, соответственно, убежденность в том, что с ними должны считаться при решении образовательных проблем, затрагивающих их родительские или профессиональные интересы.

Внутрисистемные процессы приводят к пониманию того, что школа должна меняться, но характер этих изменений должен быть предметом согласования всех участников образовательных отношений.

\section{4. Эволюция образовательных отношений}

О личностной ценности школьного образования дают представление результаты исследования «Выпускник петербургской школы», которое проводилось с 1993 по 2020 г. под руководством С. Г. Вершловского, а затем М. Д. Матюшкиной [Матюшкина].

Программа исследования включала вопрос к выпускникам «Как вы полагаете, что дала вам школа?» (табл. 24).

Показатели 2020 г. по сравнению с показателями 2001 г. в трех случаях понизились, в одном случае остались прежними, в четырех случаях стали выше. В условиях повышения значимости метапредметных результатов (которые определяются в терминах ключевых компетентностей) удовлетворенность достижением этих результатов на протяжении 20 лет выказывают меньше половины выпускников школы. При этом снижается значимость традиционных результатов (школа дала знания, школа помогла выбрать профессию, школа научила самостоятельно работать).

С. Г. Вершловский, анализируя результаты многолетнего исследования ценностных позиций выпускников петербургской школы, пришел к выводу, что академические достижения, на которые школа ориентирует учащихся, не означают и не оличетворяют для учащихся ни освоение жизненно важных умений, ни изменение их сочиального статуса, ни приобретение нового опыта, ни открытие новых перспектив, ни изменения в жизненных планах. Академические достижения являются для большинства учащихся лишь ключом к сдаче экзаменов. 
Ответы выпускников на вопрос «Что дала вам школа?», \%

\begin{tabular}{|l|c|c|c|c|}
\hline \multicolumn{2}{|c|}{ Вариант ответа } & \multicolumn{4}{c|}{ Год } \\
\cline { 2 - 5 } & $\mathbf{2 0 0 1}$ & $\mathbf{2 0 0 5}$ & $\mathbf{2 0 0 9}$ & $\mathbf{2 0 2 0}$ \\
\hline Школа дала мне знания & 82 & 75 & 67 & 59 \\
\hline Здесь я приобрел друзей & 67 & 73 & 67 & 66 \\
\hline $\begin{array}{l}\text { Школа помогла мне лучше понять себя, свои положительные } \\
\text { качества и недостатки }\end{array}$ & 22 & 26 & 22 & 33 \\
\hline Школа помогла мне определить свои интересы, выбрать профессию & 27 & 22 & 16 & 20 \\
\hline Школа научила меня критически мыслить, рассуждать, доказывать & 30 & 31 & 26 & 37 \\
\hline Школа научила меня разбираться в людях, общению с ними & 37 & 43 & 36 & 50 \\
\hline Школа подготовила меня к участию в общественной жизни & - & 24 & 26 & 30 \\
\hline Школа научила меня самостоятельно работать & & & \\
\hline
\end{tabular}

* В опросе 2020 г. этот вариант ответа был заменен на близкий по смыслу: «Школа научила меня учиться».

Снижение значимости школьного образования для учащихся проявляется в увеличении доли учащихся, которым учиться в школе неинтересно: в 2012 г. она составила 13,8\% опрошенных, а в 2020 г. - 22,4\%.

Тенденции, выявленные в исследовании «Выпускник петербургской школы», подтверждаются материалами международного сравнительного исследования PISA. Судя по этим данным, российская школа не обеспечивает достижение значительной частью учащихся уровня функциональной грамотности. Интересные данные были получены при сравнении результатов российских школьников по математике в исследованиях TIMSS (оцениваются полученные математические и естественно-научные знания) и PISA (оценивается умение применять полученные знания в реальных жизненных ситуациях). В первом случае российские школьники показали одни из лучших результатов, во втором случае они относятся к школьникам из стран со сравнительно низкими результатами.

Если есть основания полагать, что традиционное школьное образование, ориентированное преимущественно на освоение предметных знаний и умений, теряет свою значимость для учащихся, то этого нельзя сказать про целевые ориентиры учителей. По данным исследования, проведенного Высшей школой экономики, основой для учителей остается фокусировка на предметных знаниях. Социальные навыки и умения учиться учителя чаще относят к сфере ответственности семьи. Не более четверти опрошенных учителей рассматривают школу как площадку, где формируются навыки взаимодействия с другими людьми. Учителя практически не видят роли школы в воспитании ответственных граждан - лишь 15,3\% опрошенных относят эту задачу к функциям школы [Навыки...].

Существует и может получить дальнейшее развитие противоречие между представлениями о ценности образования у учащихся и учителей. При этом учащиеся ощущают дефициты современного школьного образования, а учителя чаще не придают достаточного значения имеющимся возможностям школьного образования. Интересы учащихся, учителей и родителей сочетаются, когда речь идет о выпускных экзаменах. Но если общие интересы относятся исключительно или главным образом к экзаменам, к показателям 
успеваемости, то следствием является снижение потенциала системы школьного образования, который оказывается востребованным далеко не в полной мере.

Отношение к школьному образованию разных групп участников образовательного процесса сказывается на их отношениях между собой, на которые также влияют внесистемные и внутрисистемные процессы, о которых речь шла выше.

Общей чертой, характеризующей отношения участников образовательного процесса, являются их представления о статусе - своем и других участников образовательных отношений. Под статусом в данном случае понимается представление участника образовательных отношений о своей роли в образовательном процессе и о должном отношении к нему со стороны других участников процесса.

Отношения «учитель - ученик» в советской школе характеризовались тем, что ученик воспринимался как участник учебного процесса, который должен освоить определенный учебный предмет. В постсоветское время получила распространение концепция личностно-ориентированного обучения, предполагающая отношение к ученику прежде всего как к личности, имеющей свои взгляды, позиции, ценностные ориентации. В массовой практике складывается, но пока не доминирует отношение к ученику как учащемуся, имеющему не только определенные обязанности, но и права.

Отношения «ученик - учитель» в советской школе характеризовались тем, что ученики воспринимали учителя прежде всего как должностное лицо, которое надо слушать и которому надо подчиняться. Его социальный статус, служебное положение, образованность не было принято оценивать, и они не оценивались, хотя некоторые личностные качества были предметом оценки и могли высоко цениться (наиболее значимым личностным качеством учителя считалась справедливость).

В постсоветское время в отношениях учеников к учителю произошли некоторые изменения: ученики могли интересоваться гражданской позицией учителя, его взглядами, проявлять готовность к доверительному общению с учителем, обсуждению с ним своих личностных проблем. Учитель в глазах учащихся - уже не только (в ряде случаев и не столько) должностное лицо, но и значимый собеседник, доверенное лицо, готовое встать на защиту ученика.

Взаимоотношения учителей и учащихся в условиях советской школы носили преимущественно «межфункциональный» характер - каждый должен был выполнять свои функции в рамках учебного процесса. «Межфункциональный» характер взаимоотношений сохраняется, но он может дополняться и межличностными отношениями.

Для отношений учащихся и учителей более существенное значение приобретают отличия в уровне образованности.

На проблему соотношения потенциалов учителя и ученика обращали внимание еще 50 лет назад. 26 августа 1970 г. в «Литературной газете» была напечатана статья Л. Борисовой и В. Переведенцева «Кто он, школьный педагог?». В ней были приведены данные обследования большой группы старшеклассников и преподавателей 5-10-х классов. Оно показало, что 60-70\% учеников больше осведомлены в новейших достижениях науки, техники и культуры по сравнению с их учителями. Авторы сделали следующий вывод: «Наш учитель, конечно, не стал хуже. Напротив, он сегодня образованнее, 
чем был вчера. Однако те, кого он должен обучать и воспитывать, изменились еще больше. Можно сказать, что потенциал учителя возрос, но разность потенциалов между учителем и учеником уменьшилась».

В настоящее время общепризнанно, что учащиеся могут превосходить многих учителей в умении использовать современные информационно-коммуникационные технологии. Есть учащиеся, чей уровень финансовой грамотности выше, чем у учителей, которые их обучают. Есть ученики, которые имеют более богатый опыт зарубежных поездок по сравнению с учителями. Наблюдаются случаи, когда отдельные ученики в классе лучше ориентируются в современной литературе, чем их учителя литературы.

В учительской среде в постсоветское время стала возникать напряженность в связи с использованием понятия образовательных услуг применительно к педагогической деятельности и в связи с усилением социального расслоения общества, в котором появились богатые и бедные.

Понятие «образовательная услуга», вполне применимое в рамках обсуждения проблем экономики образования, в педагогическом сообществе стало восприниматься как нравственная категория, означающая принижение смысла педагогической деятельности как миссии, служения, предполагающего признательность и благодарность со стороны общества. Данное понятие стало интерпретироваться как попытка перевести учителей на более низкую ступень социальной лестницы.

К этому добавилось снижение уровня материальной обеспеченности учителей, привыкших считать себя принадлежащими к слою интеллигенции и потерявших в значительной мере возможность удовлетворять запросы интеллигентного человека.

В последнее время стали все чаще возникать ситуации, когда учителя ощущают свою незащищенность от необоснованных требований, неправомерных претензий и даже от физического насилия.

В постсоветской школе изменился характер взаимоотношений учащихся. В школе основной формой организации взаимодействия учащихся является класс. Функции класса в образовательном процессе могут меняться. Первоначально школьный класс был создан для того, чтобы можно было обучать по единой учебной программе большую группу детей одного возраста. Но уже на начальном этапе формирования предметно-классно-урочной системы было заложено противоречие: учащиеся одного возраста могут отличаться уровнем знаний. Противоречие пробовали решить за счет второгодничества (в классах могли быть «переростки»), а после отказа от практики второгодничества - за счет индивидуального подхода к учащимся.

В условиях советской школы класс рассматривался как детский коллектив, обладающий большими воспитательными возможностями, реализовывать которые оказывалось все сложнее.

В постсоветской школе произошел ряд существенных изменений в школьном классе. Прекратили свою деятельность комсомольская и пионерская организации. В связи с этим была утрачена привычная внутренняя структура класса (октябрятские «звездочки», пионерские звенья, комсомольские группы). Сокращается число учащихся в классе (но нельзя сказать, что это приводит к существенно новым образовательным результатам). Появляется практика индивидуального обучения, которая показывает, что в этом случае утрачиваются какие-то значимые возможности групповой работы (хотя приобретаются и новые возможности). 
Одновременно происходят изменения и в жизненном пространстве детей: класс перестает быть основным объединением для многих из них, поскольку они могут входить и в различные «внеклассные» и «внешкольные» группы, в неформальные молодежные объединения, в виртуальные группировки. В каждом таком объединении может существовать своя система ценностей, в том числе и таких, которые не совпадают с ценностной системой школы. Среда общения учащихся оказывает сильное влияние на их представления о том, что «прилично» знать и уметь в соответствующем возрасте и что «неприлично» не знать или не уметь (такие представления могут относиться и к читательским интересам, и к поведению в социальных сетях, и к другим сферам социальной активности).

В то же время растет социальный запрос на формирование у школьников опыта совместной деятельности, умение работать в команде, которое весьма ценится во многих сферах профессиональной деятельности.

В этих условиях и возникает задача изучения возможностей школьного класса в организации взаимодействия учащихся при реализации современных целей школьного образования. В постсоветской школе получают распространение (хотя и в ограниченных масштабах) другие организационные формы взаимодействия учащихся: разновозрастные учебные, исследовательские, проектные группы.

Организационными формами взаимодействия учителей являются педагогический совет, методические и другие объединения учителей. Далеко не всегда объединения учителей представляют собой педагогические коллективы, и не все педагогические коллективы могут быть охарактеризованы как педагогический ансамбль.

Изменения наблюдаются в отношениях учителей и родителей учащихся. При этом чаще отмечается, что родители лучше относятся к учителям, чем учителя к родителям. В отношениях учителей доминирует представление о том, что родители стремятся переложить свои обязанности на школу, выступают с необоснованными претензиями к школе и вмешиваются во внутришкольные дела. Родители признают трудности педагогической деятельности, но часто высказывают неудовлетворенность тем, что педагоги не проявляют интереса к индивидуальным особенностям детей и что отношение в школе к детям может зависеть от социального статуса родителей.

Во взаимоотношениях родителей новое явление в постсоветский период - возникновение родительских сообществ, коммуникация в которых осуществляется через социальные сети. Результатом обмена мнениями относительно ситуации в конкретном классе сможет стать выработка общей тактики поведения с учителем или школьной администрацией.

Общую тенденцию можно охарактеризовать как переход к многокритериальной оценке участников образовательного процесса, которая выражается в том, что они могут оцениваться с различных точек зрения: как образованные люди; как люди, принадлежащие к определенному социальному слою; как личности; как индивидуальности.

Таким образом, происходят изменения в отношениях участников образовательного процесса к самим себе, в отношениях внутри каждой группы участников образовательного процесса и в отношениях между этими группами. Проблемы, обусловленные данными изменениями, заключаются в несоответствии уровня взаимодействия участников образовательного процесса возможностям системы образования. Существующий уровень взаимодей- 
ствия является фактором, препятствующим реализации терминальных ценностей образования, ограничивающим возможности системы образования инструментальными ценностями. Возникает вопрос о возможности управления образовательными отношениями и в связи с этим - вопрос о позиции школьных администраторов, об их отношении к участникам образовательного процесса как субъектам деятельности.

Отношение руководителей школ к позициям учащихся, учителей, родителей может быть различным, поскольку оно определяется многими факторами. Вместе с тем было бы важно выделить факторы, которые в равной степени влияют на взгляды руководителей школ, когда они определяют допустимую и необходимую меру регламентации образовательного процесса и, соответственно, права его участников на самостоятельные решения. Если ценность образования зависит в решающей степени от значимости его результатов, то можно предполагать, что позиция руководителей школ определяется существующими требованиями к образовательным результатам в условиях, когда качество образования все больше зависит от его индивидуализации.

Ориентация на индивидуализацию образовательных результатов означает необходимость рассмотрения вопроса о соотношении общих и индивидуальных результатов школьного образования и критериях их оценки.

Различия в достигнутых результатах фиксировались и фиксируются по пятибалльной шкале оценивания в диапазоне «отличные - неудовлетворительные результаты». Данный подход ориентируется на достижение одинаковых результатов, не отличающихся содержанием и уровнем освоенного учебного материала. Такая ориентация обусловила широкое применение методов принудительного обучения, реализация которых отрицала саму возможность отношения к учащимся как субъектам образовательного процесса. В ситуации, когда образовательные результаты все больше зависят от мотивов образовательной деятельности, предпринимаются попытки поиска педагогических средств, обеспечивающих качественное изменение мотивов образовательной деятельности учащихся - переход от мотивации долга к мотивации интереса.

В середине 1980-х гг. был выдвинут принцип сотрудничества всех участников образовательного процесса. 18 октября 1986 г. в «Учительской газете» был опубликован отчет о встрече учителей-экспериментаторов, главным результатом которой стала своеобразная педагогическая декларация, излагавшая основные идеи педагогики сотрудничества. В манифесте «Гуманистическая педагогика: XXI век», подготовленном группой известных в профессиональной среде экспертов в области образования (А. Г. Асмолов, И. М. Реморенко, Т. М. Ковалева, И. Д. Фрумин и др.) и опубликованном в 2015 г., говорится о перспективах перехода к массовому персональному образованию, в системе которого должен быть услышан голос ученика при постановке целей и определении средств образования. В последующие годы идея персонализации образовательной деятельности учащихся получила дальнейшее развитие.

К характеристикам современной системы образования относятся следующие позиции: «учащиеся берут ответственность за собственные достижения на себя; оценивание предназначено для того, чтобы подтверждать достижения, а не наказывать за неудачи» [Де Корте, с. 32]. Ориентация на оценку достижений учащихся в образовательной деятельности дает основание для вывода о том, что такие достижения могут быть разными, но равноценными с точки зрения решения проблем, имеющих личностную значимость для 
учащихся. Такой вывод соответствует взглядам на неизбежность перехода к персонализированному образованию.

Управление образовательными отношениями предполагает качественные изменения системы образования. К ним относятся изменения в информационном обеспечении деятельности всех участников образовательных отношений, смысл которых заключается в создании предпосылок для того, чтобы и учителя, и родители учащихся, и сами учащиеся ощущали себя полноценными субъектами образовательной деятельности, имеющими возможность влиять на ее организацию и содержание, а также принимать на себя ответственность за результаты собственной деятельности.

\section{5. Цифровизация образования как фактор изменения образовательных отношений}

В настоящее время наиболее значимым фактором, способным привести к качественным изменениям информационного обеспечения образовательных отношений, является цифровизация образования, которая стала фактом - процессом, происходящим в системе образования. В связи с этим необходимо рассмотреть возможное влияние процесса цифровизации на эволюцию образовательных отношений. При этом следует исходить из того, что данное влияние может быть как позитивным, так и негативным. С позиций аксиологического подхода влияние цифровизации образования на развитие общеобразовательных отношений можно оценить как позитивное, если в конечном счете получит развитие отношение к образованию как к терминальной ценности. Если будет и дальше развиваться отношение к образованию как к инструментальной ценности (и при этом будет доминировать ориентация на весьма ограниченные инструментальные ценности), то такой процесс может оцениваться скорее как отрицательный.

Конечно, ценностное отношение к образованию определяется не столько решением задач информационного обеспечения участников образовательного процесса, сколько другими факторами. Но отношение к процессу цифровизации, акцент на его технологических или концептуальных аспектах может влиять и на отношение к образованию как ценности, тем более в ситуации, когда в направленности трансформационных процессов в сфере образования доминирует тенденция технократизации, а не гуманитаризации образования.

Практика дистанционного обучения в условиях пандемии резко стимулировала интерес и учителей, и школьных администраторов, и родителей учащихся к проблемам цифровизации образования и оценки его непосредственных и отсроченных результатов. Одновременно стали разрабатываться концепции образовательного процесса в условиях новой образовательной среды.

Взгляды на новые возможности образовательного процесса нашли отражение в понятийном аппарате, который стал использоваться для описания особенностей цифрового образования: база данных, информационная система, электронный образовательный ресурс, инструменты и средства цифрового образования, цифровое образовательное пространство, цифровые образовательные технологии, технологии онлайн-обучения, сетевое поколение, сетевые сообщества, интернет-зависимость [Цифровое образование...]. 
В образовательной практике, при обсуждении возможностей цифрового образования, акцент чаще всего делается на вопросах цифровой компетентности - на развитии у учащихся способности уверенно, грамотно выбирать и использовать информационно-коммуникационные технологии (ИКТ) в разных сферах образовательной деятельности, чаще - при решении познавательных задач, реже - при решении коммуникативных задач, еще реже - при решении аналитических задач, при осуществлении рефлексивной деятельности. Практика дистанционного обучения вызвала интерес к использованию ИКТ для решения учащимися задач самоорганизации образовательной деятельности.

Вместе с тем в имеющихся исследованиях обращают внимание на то, что взаимодействие человека с новой информационной средой может стать фактором приобретения человеком новых возможностей, которые повлияют на его самоопределение и характер взаимодействия с другими людьми. К таким возможностям относятся: свобода выбора и разнообразия во всех сферах жизни; быстрый поиск ответов на любой вопрос в Интернете; решение проблем «здесь и сейчас»; «персональные настройки» (предпочтение индивидуального стиля деятельности); «кооперация» (возможности для соучастия, сотрудничества, сотворчества); контроль над информацией и действиями; доступ к развлечениям в режиме 24/7 [Там же, с. 140-141].

Применительно к системе школьного образования можно высказать ряд предположений об изменениях межсубъектных отношений в условиях цифровизации образовательного процесса.

Отношения в различных сферах социального управления основываются на том, что управленческие решения должны быть правомерными, целесообразными и соответствовать нормам морали. Эти критерии применимы к оценке отношений участников образовательного процесса, которые выступают в роли субъектов решений. В рамках такого подхода отношения между участниками образовательного процесса определяются тремя факторами: легитимностью их статуса, функциональной взаимозависимостью, харизмой.

Легитимность статуса (представления о функциях - правах, обязанностях, ответственности участников процесса) основывается на существующих нормативных актах («имеет право», «должен»), традициях («всегда так было») и оценке компетентности («они в этом не разбираются»). В условиях цифровизации отношение детей к взрослым участникам процесса (учителям, родителям) как лицам, имеющим безусловное право на предписания учащимся по вопросам учебной деятельности, утрачивается. Одновременно меняется представление учащихся о собственном статусе, поскольку расширяется сфера решений, которые они могут принимать на основе самостоятельно полученной информации из банка данных.

Функциональная взаимозависимость выражается в том, что выполнение функций одним участником процесса зависит от того, как свои функции выполняют другие участники процесса (учителей без учеников не бывает; учитель может учить, если ученики учатся). Следствием существующей взаимозависимости является оценка действий участников образовательного процесса как целесообразных или нецелесообразных. В условиях цифровизации возможна автономизация участников образовательного процесса: использование электронных устройств для организации и оценки учебной деятельности учащихся, выбор учащимися источников образовательной информации; доступ родителей к наблюдениям за ходом образовательного 
процесса и к информации, позволяющей сравнивать локальные образовательные системы; доступ учителей к нормативной и методической информации, обеспечивающий возможность формирования независимой педагогической позиции; использование участниками образовательных отношений социальных сетей для определения собственных референтных групп. Следствием указанных возможностей может стать снижение потребности во взаимодействии участников образовательных отношений.

Харизма участников образовательного процесса (учащихся для учителей, учителей для учащихся, родителей для педагогов и т. д.) обусловлена их привлекательностью, личностными качествами, ценностными установками. В условиях цифровизации значимость учителей как специалистов в определенных предметных областях может снижаться, но одновременно их значимость может возрастать как носителей культуры, способных показывать образцы культуры речи, культуры общения, культуры труда, отношения к ценностям культуры. Вполне возможны изменения в критериях оценки и других участников образовательных отношений.

Вероятны изменения не только в межсубъектных отношениях, но и в оценке значимости школьного образования. Одним из критериев оценки значимости школьного образования станет создание условий для его персонификации. Персонификация может выразиться в расширении возможности выбора элективных и факультативных курсов, в обеспечении возможности разработки индивидуального учебного плана на модульной основе, в возможности для учащихся определять планируемый уровень усвоения учебного предмета, в формировании индивидуальных комплектов средств обучения (за счет использования электронных образовательных ресурсов), в возможности выбора форм и режима обучения, способов познавательной, коммуникативной и рефлексивной деятельности.

Расширение доступности образовательной и методической информации, наличие банка готовых ответов, ориентация на алгоритмизацию учебного процесса могут стать факторами ориентации на минимизацию временны́х затрат на решение образовательных задач и факторами, способствующими развитию дилетантизма и в познавательной, и в профессиональной деятельности.

Указанные возможности противоречивы. Их востребованность, скорее всего, будет определяться стратегическим направлением развития системы образования.

Ориентация на персонализированное образование предполагает изменения в информационном обеспечении взаимодействия участников образовательного процесса. Для разработки, реализации и корректировки рабочих программ по учебным предметам учителям необходима информация об уровне подготовленности учащихся к освоению программы, о промежуточных и итоговых результатах, степени их соответствия требованиям стандартов, степени их соответствия результатам, полученным другими учителями в сходных условиях.

Для обеспечения взаимодействия учителей разных предметов им необходима информация о достигнутых метапредметных и личностных результатах. Необходимая для учителей информация не может быть представлена в виде пятибалльной шкалы оценок из-за ее малой информативности. Такие оценки в лучшем случае выступают как показатели сравнительного благополучия/ неблагополучия, как сигналы для принятия не вполне определенных мер. 
Школьные отметки остаются основным источником обратной связи для учащихся. Повысить значимость отметок как средства обратной связи пытаются за счет увеличения их «накопляемости». Предполагается, что частота оценивания может позитивно влиять на качество учебной деятельности учащихся. На деле повышение частоты оценивания ведет к снижению самостоятельности учащихся, поскольку функции регулирования их деятельности выполняют учителя, а не сами учащиеся. Оценивание по пятибалльной шкале не обеспечивает учащихся достаточно конкретной информацией о факторах их успехов/неудач в учебной деятельности.

При ориентации на достижение учащимися равноценных, но разных результатов роль учителей, родителей и самих учащихся в организации образовательного процесса существенно меняется, потому что они должны проявить себя как субъекты целеполагания.

Если все участники образовательного процесса будут выступать как субъекты образовательной деятельности и отношения между ними приобретут межсубъектный характер, то произойдут изменения в их отношении к самому образовательному процессу.

Цифровизация образовательного процесса в любом случае будет влиять на отношения его участников, но как именно - это зависит не столько от освоения цифровых инструментов участниками образовательных отношений, сколько от их ценностных ориентиров. В связи с этим управление образовательными отношениями необходимо рассматривать в логике системных изменений школьного образования, одним из которых является его цифровизация.

\section{Общие выводы}

Социальная значимость системы общего образования зависит от ее личностной значимости. Повышение социальной значимости школьного образования возможно, если это образование будет рассматриваться участниками образовательных отношений не только как инструментальная, но и как терминальная ценность. Основными факторами, определяющими ценностное отношение к школьному образованию участников образовательного процесса, являются их отношение к данному процессу и их межсубъектные отношения.

Одним из факторов управления развитием образовательных отношений является цифровизация образовательного процесса, возможности которой альтернативны. Ее следствиями могут быть и автономизация участников образовательного процесса (что приведет к снижению потенциала системы образования), и развитие их взаимодействия, основанного на общих ценностях, что позволит полнее реализовать потенциал системы образования.

\section{Литература}

1. Асмолов А. Г. Оптика просвещения: социокультурные перспективы. М. : Просвещение, 2012.

2. Вайткявичюс Ю. В. Развитие знаний учащихся двух поколений (на материале физической географии, ботаники, физики и химии в 5-8 классах) : дис. ... д-ра пед. наук. Вильнюс, 1973.

3. Ван Гиг Дж. Прикладная общая теория систем : пер. с англ. Т. 1. М. : Мир, 1991. 
4. Гусинский Э. Н., Турчанинова Ю. И. Введение в философию образования. М. : Логос, 2000.

5. Де Кортеэ. Проектирование учебного процесса: создание высокоэффективных образовательных сред для развития навыков саморегуляции // Вопросы образования. 2019. № 4.

6. Днепров Э. Д. Новейшая политическая история российского образования. М. : Мариос, 2011.

7. Запесоцкий А. С. Образование: философия, культурология, политика. М. : Наука, 2002.

8. Касаткин П. И. Аксиология образования: архитектоника современного образовательного пространства. М. : МГИМ0-Университет, 2018.

9. Кирьянова А. В. Педагогическая аксиология / А. В. Кирьянова, Г. А. Мелекесов, Л. В. Мосиенко, Т. А. Ольховая. М. : Инфра-М, 2018.

10. Лебедев О. Е. Управление образовательными системами. М. : Логос, 2012.

11. Лебедев О. Е. Управление образовательными системами: исследовательский проект. СПб. : нИУ вШЭ - Санкт-Петербург, 2016.

12. Лебедев О. Е. Управление образовательными системами: теория и практика. СПб. : НИУ ВШЭ — Санкт-Петербург, 2011.

13. Матюшкина М. Д. Выпускник петербургской школы: от поколения Y к поколению Z: рукопись.

14. Навыки XXI века в Российской школе: взгляд педагогов и родителей / М. С. Добрякова, 0. В. Юрченко, Е. Г. Новикова. М. : НИУ ВШЭ, 2018.

15. Новиков А. М. Основания педагогики. М. : Этвес, 2010.

16. Образование в Российской Федерации. 2010 : статистический сб. М. : Государственный университет — Высшая школа экономики, 2010.

17. Педагогическая энциклопедия. Т. 3. М. : Советская энциклопедия, 1966.

18. Российская педагогическая энциклопедия. Т. 2. М. : Большая Российская энциклопедия, 1999.

19. Российская школа: начало XXI века / под ред. С. Г. Косарецкого, И. Д.Фрумина. М. : НИУ ВШЭ, 2019.

20. Смыслы и цели образования: инновационный аспект : сб. науч. трудов / под. ред. А. В. Хуторского. М. : ЭНЭК, 2007.

21. Твенге Дж. Поколение І. Почему поколение Интернета утратило бунтарский дух, стало более толерантным, менее счастливым и абсолютно не готовым ко взрослой жизни. М. : Рипол-классик, 2019.

22. Хэтти Дж. А. С. Видимое обучение / под ред. В. К. Загвоздкина, Е. А. Хамраевой. М. : Научное образование, 2017.

23. Цифровое образование в терминах : учеб.-метод. пособие / под ред. Е. В. Барановой. СПб. : Изд-во РГПУ им. А. И. Герцена, 2020.

24. Ядов В. А. Проблемы российских трансформаций. СПб. : Изд-во СПбГУП, 2006. 


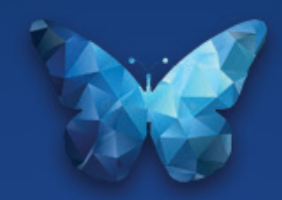

\section{BMECTO \\ ЗАКЛЮЧЕНИЯ}





\section{ВОПРОСЫ ДЛЯ ОБСУЖДЕНИЯ: ЗАЧЕМ НАМ «ЦИФРА»?}

Вопрос заключается в том, что цифровизация образовательного процесса может дать как позитивные, так и негативные результаты. В ситуации неопределенности возникает необходимость самоопределения тех специалистов, которые выступают как разработчики теоретических моделей образовательного процесса или конкретных образовательных программ. Читателям этой книги предстоит стать авторами собственных версий заключительной главы, ответив на изложенные ниже вопросы.

1. Согласны ли вы с тем, что существуют следующие проблемы, способы решения которых необходимо найти?

- Проблема повышения ченности школьного образования: родители учащихся и сами учителя рассматривают школу прежде всего как ступень подготовки к профессиональному образованию, следствием чего является лишь частичное использование возможностей школы для формирования ценностных ориентиров учащихся.

- Проблема ролевых статусов участников образовательных отношений: в условиях цифровизации учебные и образовательные ритуалы трансформируются, а отношения между участниками образовательного процесса (учащимися, учителями, родителями, школьной администрацией) в массовой образовательной практике основываются на традиционных ритуалах - дети должны выполнять предписанные им обязанности, а взрослые должны проверять и оценивать, как они выполняют эти обязанности; такие отношения препятствуют достижению личностных результатов образования.

- Проблема формирования субъектной позиции участников образовательных отношений: информация, которую получают участники образовательных отношений (включая учащихся) относительно достигнутых образовательных результатов, недостаточна для выявления факторов, определяющих эти результаты, что ограничивает возможности принятия решений, направленных на повышение качества их собственной деятельности.

- Проблема реализации потенциала прочесса цифровизации: возможности цифровизации образовательного процесса для совершенствования взаимодействия его участников используются лишь частично не столько из-за недостаточной компетентности самих участников, сколько из-за неготовности к переходу от привычных субъект-объектных отношений к субъект-субъектным отношениям.

- Проблема недоверия субъектов образовательных отношений друг к другу и к спускаемым сверху установкам на цифровую модернизацию, стремление навязать свою точку зрения, а не прийти к согласию. 
- Проблема соотношения экосистемной логики развития современноro VUCA-образования, предполагающей свободную коммуникацию паритетных образовательных персон и процесса цифровизации образования, но допускающей определенные ограничения свободы взаимоотношений персонализированных образовательных субъектов в процессе реализации «платформенного мышления».

2. Ниже указаны различные явления в сфере школьного образования. Вы согласны с тем, что эти явления наблюдаются в образовательной практике и что их стоит исследовать?

- Рейтинговый гипноз: гонка за чужим успехом.

- Отсутствие или явный дефицит признанных лидеров в сфере школьного образования.

- Изменение соотношения неуправляемых и управляемых процессов в условиях цифровизации: увеличение доли регламентированных процессов в сфере школьного образования.

- В педагогической деятельности имеет место «сдвиг мотивов на цель»: ее смыслом является достижение учащимися непосредственных образовательных результатов, а не прогнозирование их следствий.

3. Ниже указана проблематика управленческих решений, относящихся к развитию образовательных отношений. Можно ли согласиться с тем, что такие решения возможны на уровне образовательной организации?

- Правоучащихся навыбор индивидуальной образовательной программы: выбор элективных и факультативных курсов, выбор уровня освоения учебного предмета, использование форм смешанного обучения, выбор способа взаимодействия с другими учащимися, способов решения учебных задач, сроков и способов выполнения домашних заданий, право на участие или неучастие в различных формах и видах внеурочной деятельности.

- Определение позиции родителей в образовательном процессе: «дублеры учащихся», «дублеры учителей», коучи, тьюторы, организаторы учебной деятельности детей, источники «обратной связи» для учителей, авторы индивидуальных образовательных программ и др.

- Определение степени свободы и границ ответственности учителей при планировании образовательного процесса, отборе содержания, выборе образовательных технологий, выборе системы оценивания, при оценке качества профессиональной деятельности учителя. 


\section{Сведения об авторах}

\section{Алла Николаевна Бакушина}

Кандидат педагогических наук, начальник методического отдела Центра довузовских программ, проектов и организации приема в бакалавриат и магистратуру, доцент Департамента государственного администрирования НИУ ВШЭ - Санкт-Петербург.

E-mail: allabakushina@yandex.ru

\section{Наталья Алексеевна Заиченко}

Кандидат педагогических наук, профессор Департамента государственного администрирования НИУ ВШЭ - Санкт-Петербург, академический руководитель магистерской программы «Управление образованием». E-mail: zanat@mail.ru

\section{Людмила Игоревна Заиченко}

Докторант Таллинского университета, старший преподаватель Департамента государственного администрирования НИУ ВШЭ - Санкт-Петербург.

E-mail: lucia.sheren@gmail.com

\section{Ирина Николаевна Кондратьева}

Директор ООО «Студия „Март“», разработчик образовательного ресурса «Учим учиться».

E-mail: kin@mart.spb.ru

\section{Олег Ермолаевич Лебедев}

Доктор педагогических наук, член-корреспондент РАО, профессор Департамента государственного администрирования НИУ ВШЭ - Санкт-Петербург.

E-mail: o_lebed@mail.ru

\section{Ирина Алексеевна Писаренко}

Кандидат педагогических наук, доцент Института педагогики Санкт-Петербургского государственного университета, доцент Департамента государственного администрирования НИУ ВШЭ — Санкт-Петербург.

E-mail: ixkpps@gmail.com

\section{Олег Георгиевич Прикот}

Доктор педагогических наук, профессор Департамента государственного администрирования НИУ ВШЭ - Санкт-Петербург, руководитель проектной траектории магистерской программы «Управление образованием».

E-mail: o.prikot@yandex.ru

\section{Дмитрий Давидович Рубашкин}

Доцент Департамента государственного администрирования НИУ ВШЭ -

Санкт-Петербург, директор автономной некоммерческой организации «Информационный центр ТСО», разработчик образовательного ресурса «Учим учиться».

E-mail:ddr.cv.lab@gmail.com 


\title{
ЦИФРОВОЙ ДЕБЮТ ОБРАЗОВАТЕЛЬНЫХ ОТНОШЕНИЙ
}

\author{
Монография \\ Под общей редакцией \\ доктора педагогических наук, профессора О. Е. Лебедева \\ и кандидата педагогических наук, профессора Н. А. Заиченко
}
Директор издательско-полиграфического центра Е. Ю. Князев Редактор Т. А. Темкина Корректор Т. А. Темкина Верстка С. И. Широкой
Подписано в печать 15.10.2021. Формат 70×108 1/16. Усл. печ. л. 18,38.
Тираж 200 экз.

Комплекс издательско-полиграфических работ выполнен в Российской академии народного хозяйства и государственной службы при Президенте Российской Федерации, в издательско-полиграфическом центре СЗИУ РАНХиГС 199004, Санкт-Петербург, 8-я линия В. О., д. 61.

Тел.: (812) 335-42-10. Факс: (812) 335-42-16. E-mail: ph-sziu@ranepa.ru 